\title{
An Integrated Approach of Analyzing Management Solutions for the Water Crisis in Azraq basin, Jordan
}

\author{
Dissertation \\ zur Erlangung des mathematisch-naturwissenschaftlichen Doktorgrades \\ "Doctor rerum naturalium" \\ der Georg-August-Universität Göttingen
}

im Promotionsprogramm Geowissenschaften / Geographie der Georg-August University School of Science (GAUSS)

vorgelegt von

Jafar Alkhatib

aus Damaskus, Syrien

Göttingen 2017 


\section{Betreuungsausschuss}

Prof. Dr. Martin Sauter, Abt. Angewandte Geologie, Georg-August-Universität Göttingen, Prof. Dr. Lars Ribbe, ITT, TH Köln

Prof. Dr. Irina Engelhardt, Institute fuer Angewandte Geowissenschaften, TU Berlin

\section{Mitglieder der Prüfungskommission}

Referent: Prof. Dr. Martin Sauter

Korreferent: Prof. Dr. Lars Ribbe

2. Korreferent: Prof. Dr. Irina Engelhardt

Weitere Mitglieder der Prüfungskommission:

Dr. Bianca Wagner

PD Dr. Susanne Stadler

PD Dr. Tobias Licha 


\section{Printed and published with the support of the DAAD "German Academic Exchange Service"}




\section{Acknowledgement}

First of all, I would like to thank my supervisor; Prof. Dr. Martin Sauter, and my co-supervisors; Prof. Dr. Lars Ribbe and Prof. Dr. Irina Engelhardt for their help and support, which greatly contributed to the completion of this dissertation. I am grateful for you as you believed in me and gave me the chance of starting my $\mathrm{PhD}$, and were always persistent in answering my questions, and guiding me on the right path to achieve my results.

The chance of doing this $\mathrm{PhD}$ degree would have not been possible without the scholarship that the German Academic Exchange Service (DAAD) awarded me. I am really thankful for that.

I am also very indebted for Dr. Marwan Alraggad for his great scientific and administrative support in Jordan.

Special thanks go to Dr. Sara Vassolo and Dr. Klaus Schelkes at the BGR Hannover, who never hesitated to answer my questions.

I am very thankful for Dr. Suhyb Salama, ITC, the university of Twente, the Netherland for his support and help.

Additionally, I express my gratitude to the staff members at the department of Applied Hydrogeology, University Goettingen, the ITT in Cologne and Water and Environment Research and Study Center in the University of Jordan.

I am grateful to my colleagues and friends; Christian Herges, Heinz Schiedermann, Antonio Corbacho, Sonja Niemeier, Entisar Almasri, Anna Goelnitz Alberto Rivera, Lamia Nourichafi for their great support.

To whom I missed naming in this report, my sincere thanks and appreciations are extended.

And last, but not least, I would not forget the endless encouragement provided by my family, especially my father and mother. 


\section{Table of content}

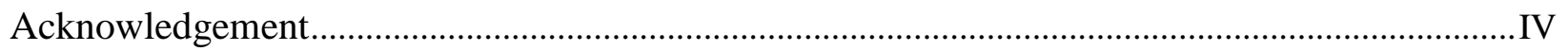

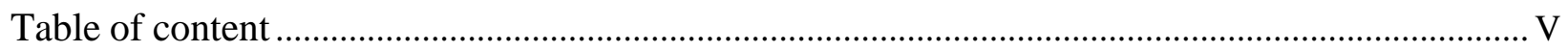

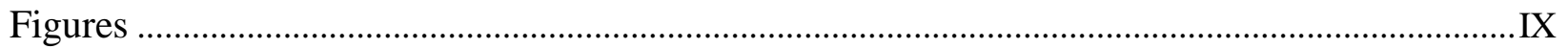

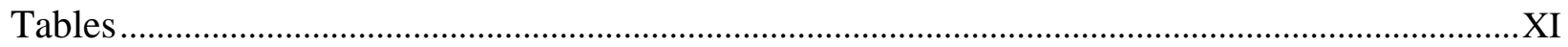

Summary

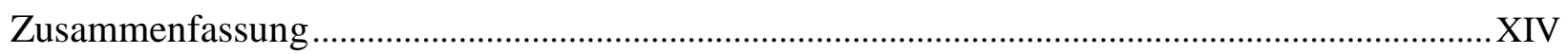

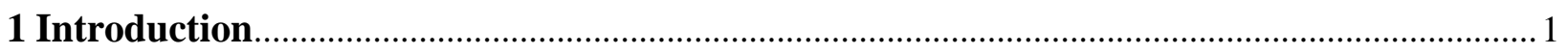

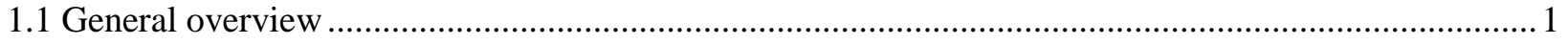

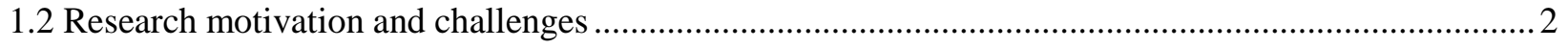

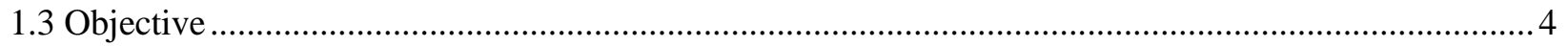

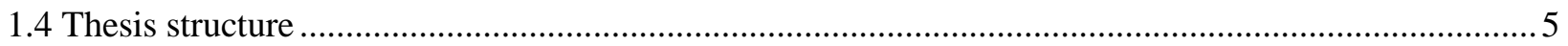

2 Study area

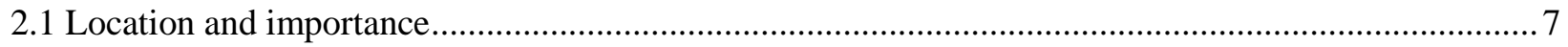

2.2 Landuse

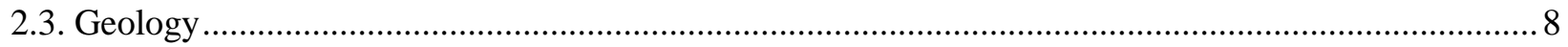

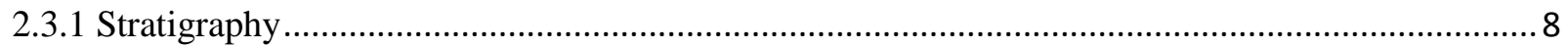

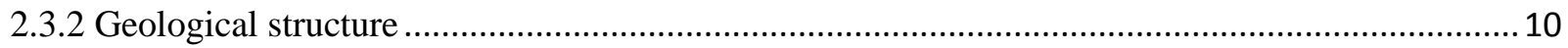

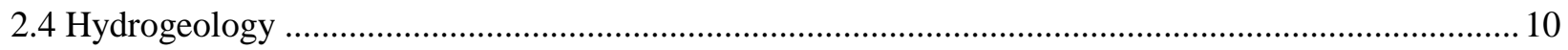

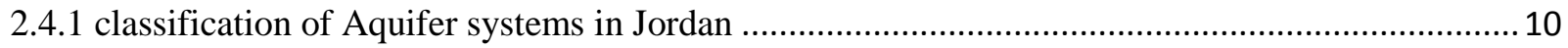

2.4.2 Aquifer systems in Azraq basin ..................................................................................... 13

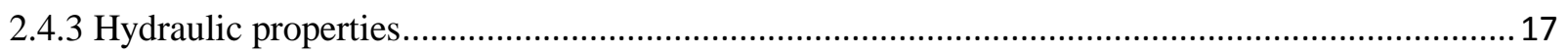

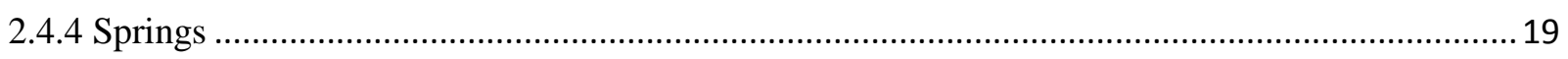

2.5 Climatology

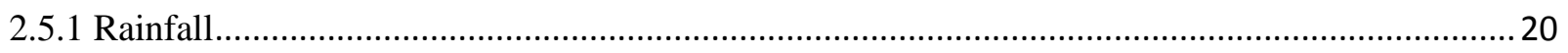

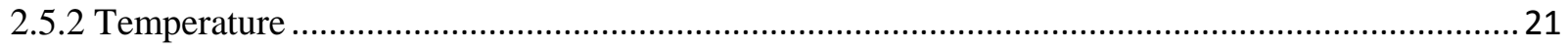

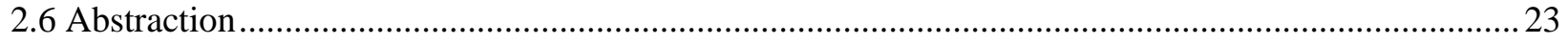




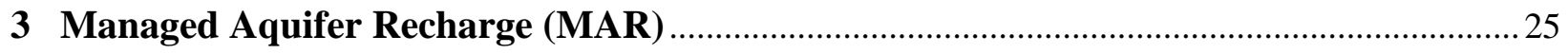

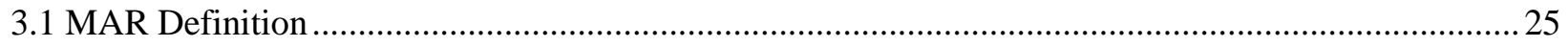

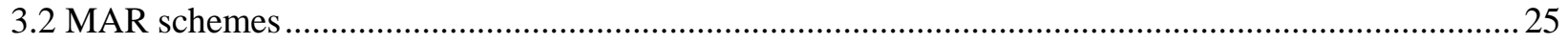

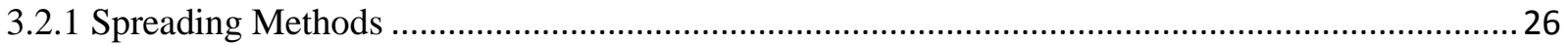

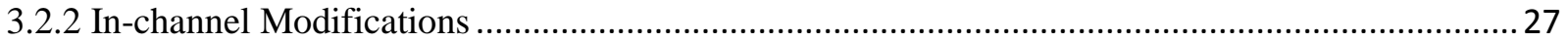

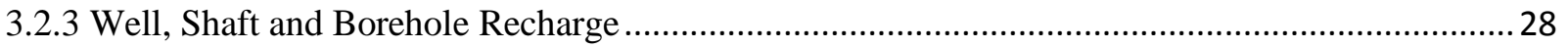

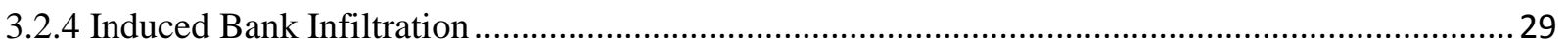

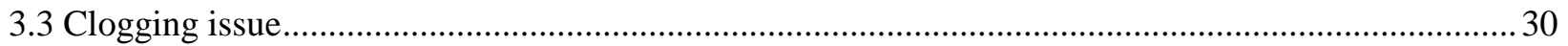

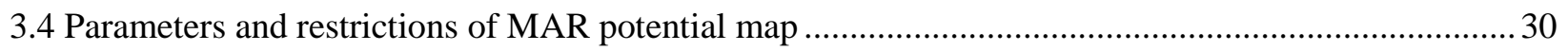

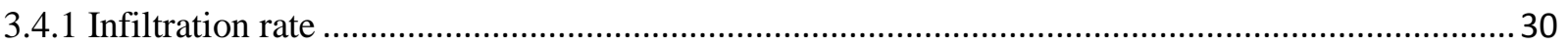

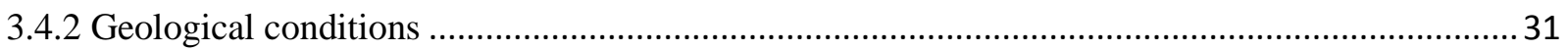

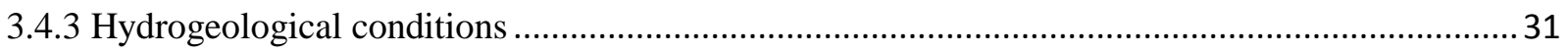

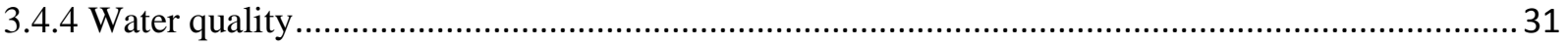

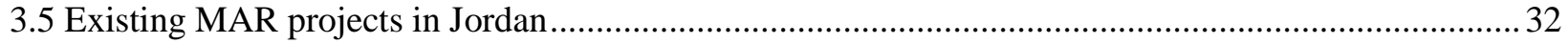

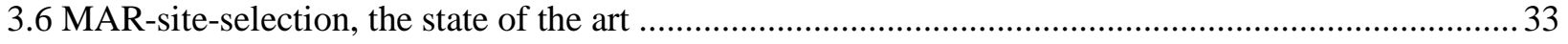

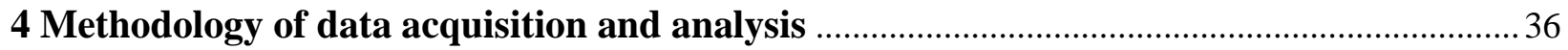

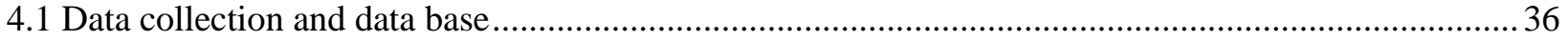

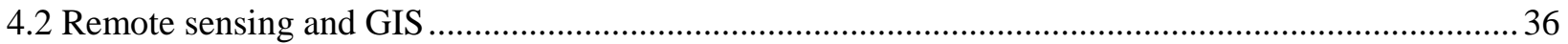

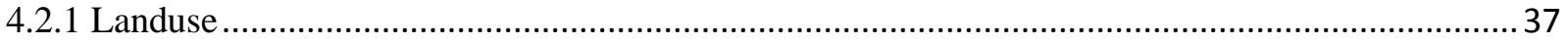

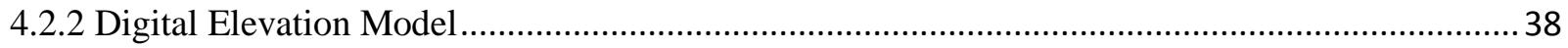

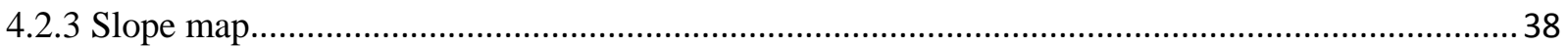

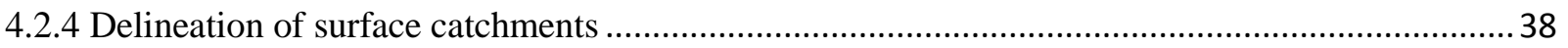

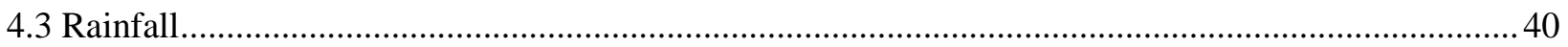

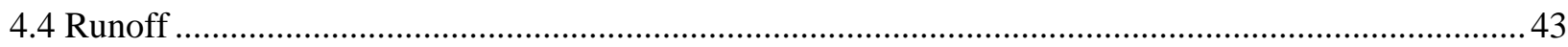

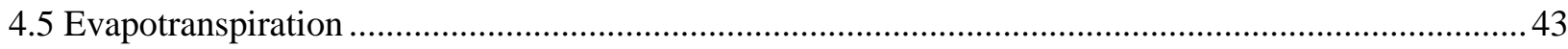

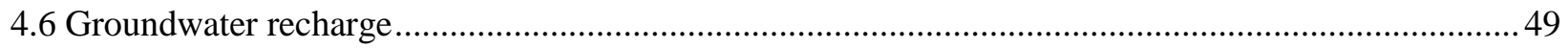

5. Development of groundwater flow model for Azraq basin ..................................................51

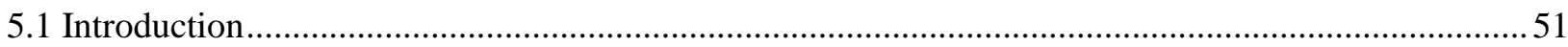

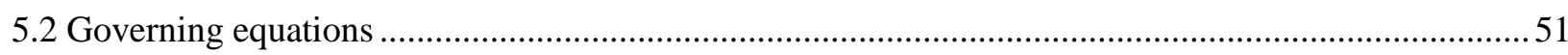

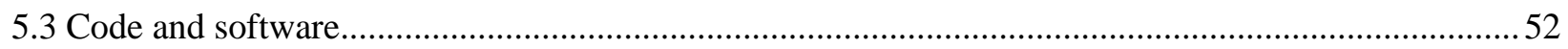

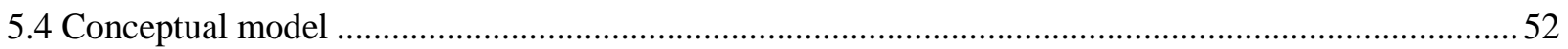

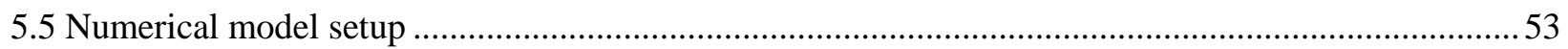




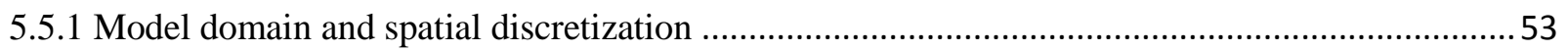

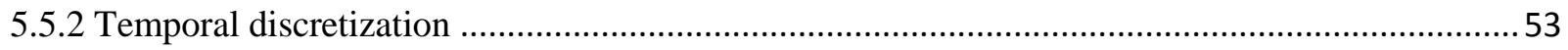

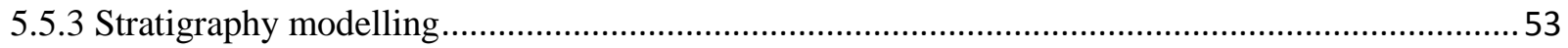

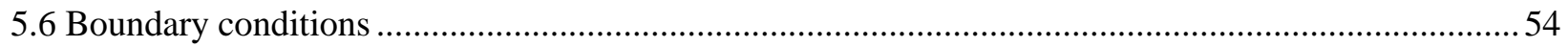

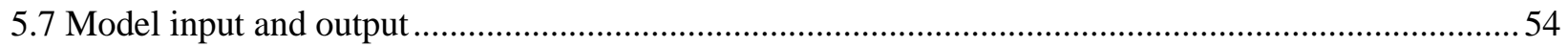

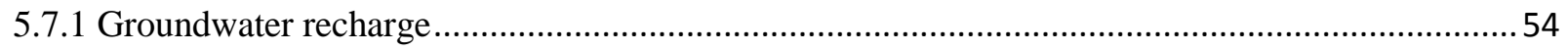

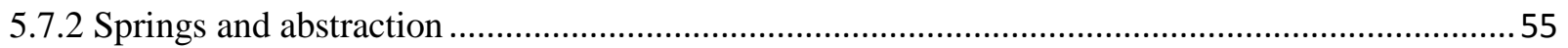

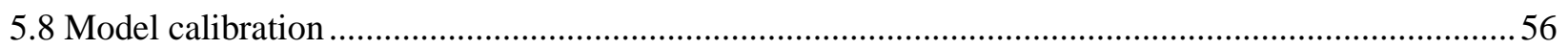

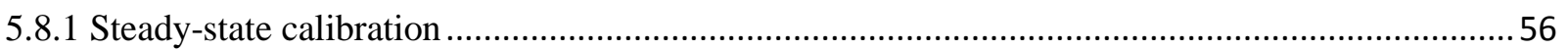

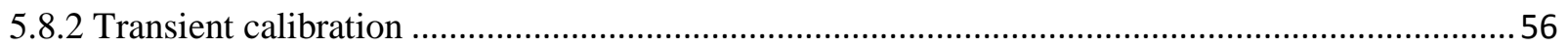

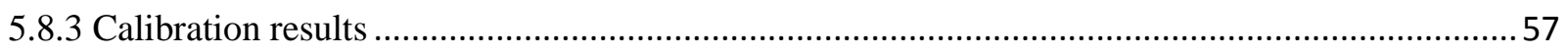

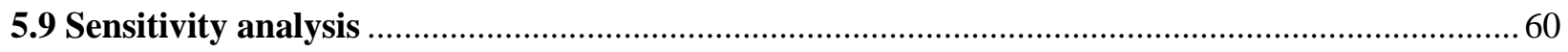

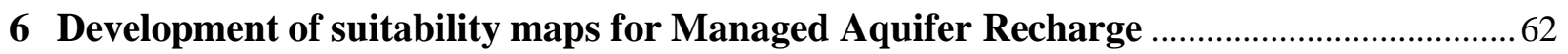

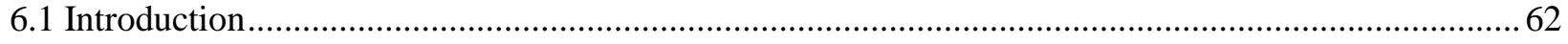

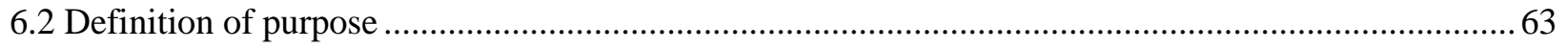

6.3 Quantitative approach for creating MAR suitability map based on subsurface characteristics ............64

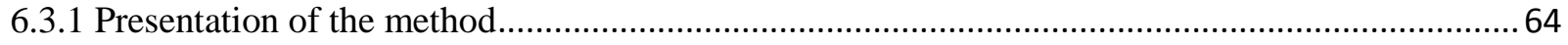

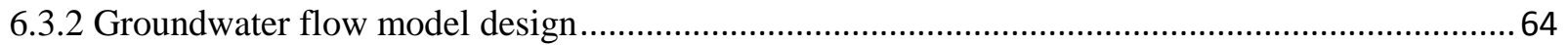

6.3.3 Assumptions for the simulation of groundwater mounding .................................................... 65

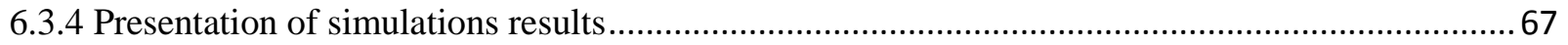

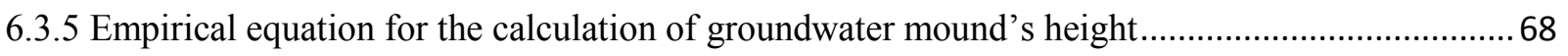

6.3.6 Application of derived equations in the generation of MAR suitability map ..............................69

6.4 Qualitative approach for creating MAR suitability map based on surface characteristics ...................72

6.4.1 Presentation of a new approach of integrating thematic layers............................................... 72

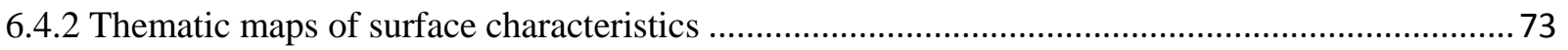

6.4.3 Application of the decision system in the Generation of MAR suitability map ........................ 74

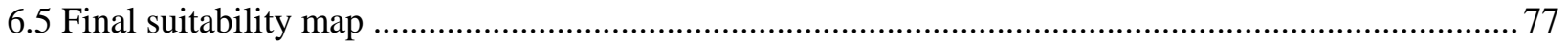

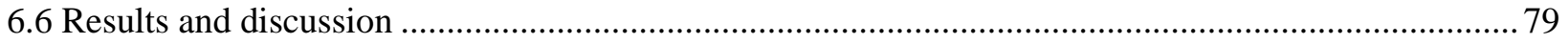

6.6.1 Calibrated equation for the simulation of Groundwater mound height ....................................80

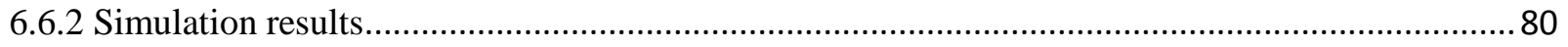

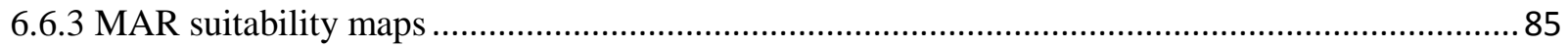


7 Assessing management strategies in the basin ............................................................. 91

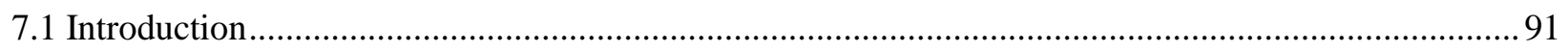

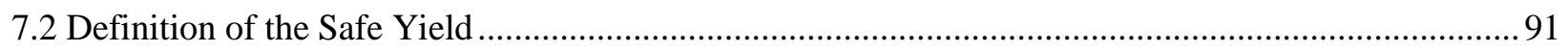

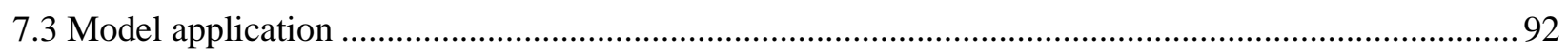

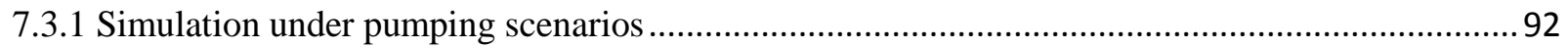

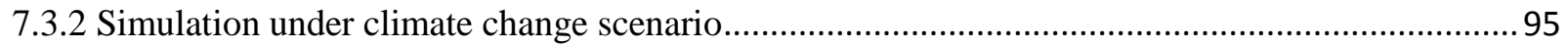

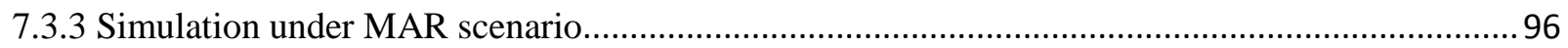

7.4 Application of Multi-criteria-Analysis in choosing abstraction rate in Azraq basin .........................99

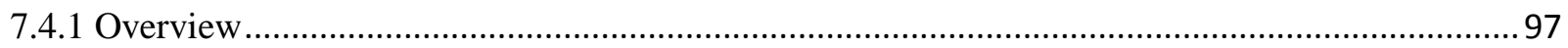

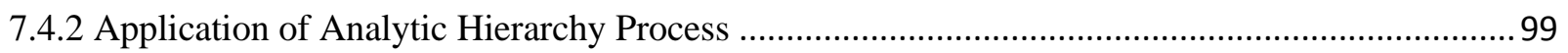

7.4.3 Identification of relevant decision alternatives and criteria ................................................. 100

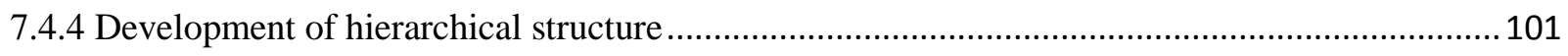

7.4.5 Specification of relative preferences and calculation of partial weights .................................. 102

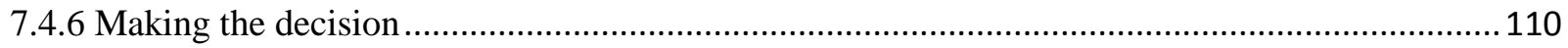

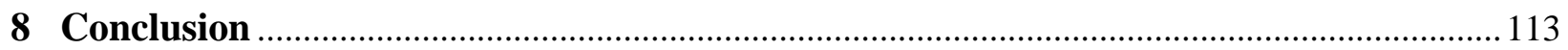

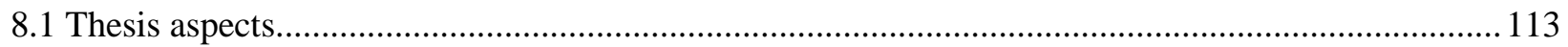

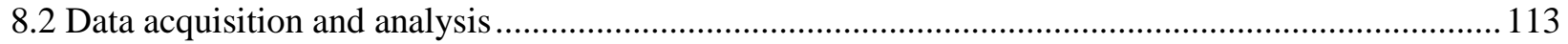

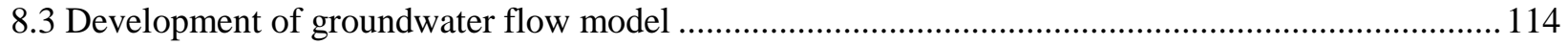

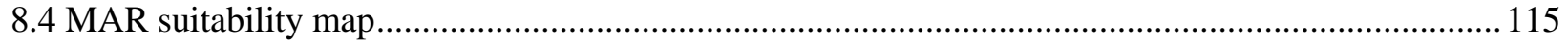

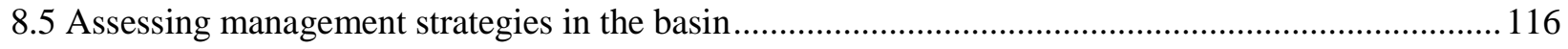

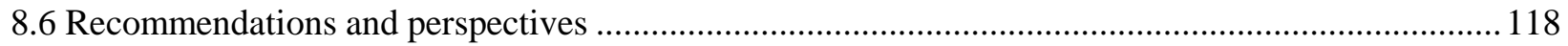

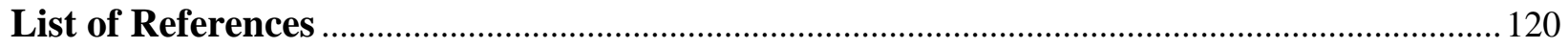

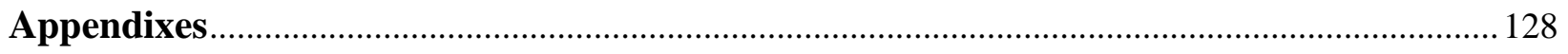




\section{Figures}

Fig. 2.1: Location of Azraq basin, (National Geographic, ESRI).

Fig. 2.2: Outcropping aquifers, farms, pumping and monitoring wells in Azraq basin 9

Fig. 2.3a: Faults and cross section in Azraq basin (MWI, 2013) 12

Fig. 2.3b: Geological cross section CC' (WAJ and BGR, 1994) 12

Fig. 2.4: Outcropping aquifers in Azraq basin 14

Fig. 2.5: Groundwater level at monitoring well F1280 (MWI, 2013) 15

Fig. 2.6a: Groundwater flow pattern of the Upper Aquifer System, arranged after (Hobler et al., 2001) 16

Fig. 2.6b: Groundwater flow pattern of the Middle Aquifer System, arranged after (Hobler et al., 2001) 16

Fig. 2.7: K values m/day derived from pumping tests for the Shallow Aquifer System (Arabtech, 1994). 18

Fig. 2.8: K values m/day derived from pumping tests for the Middle Aquifer System (Arabtech, 1994) 19

Fig. 2.9: Monthly springs discharge in Azraq basin for the period 1980-1991, (MWI, 2013) 20

Fig. 2.10: Rainfall contour map in Azraq basin prepared based on data from (MWI, 2013) 22

Fig. 2.11: Precipitation mm/year at F0004 rainfall station (MWI, 2016) 22

Fig. 2.12a: Abstraction rate through AWSA governmental wells from Azraq basin (MWI, 2013) 23

Fig. 2.12b: Abstraction rate through private wells from Azraq basin (MWI, 2013) 24

Fig. 3.1: Spreading Methods $\quad 27$

a: Infiltration Pond, b: Soil Aquifer Treatment (Gale, 2005) 27

Fig. 3.2: In-channel Modifications $\quad 28$

a: Percolation Pond, b: Sand Dam, c: Recharge Releases, 28

d: Underground Dam (Gale, 2005). $\quad 28$

Fig. 3.3: Drilled Well (Gale, 2005). 29

Fig. 3.4: Induced Bank Infiltration $\quad 29$

a: Bank Infiltration, b: Dune Filtration (Gale,2005 ). 29

Fig. 3.5: Wala Dam (Google Earth) 33

Fig. 4.1: Landsat satellite image for Azraq basin (USGS, 2013) 37

Fig. 4.2 a: USGS DEM of Azraq basin (30*30), b: Slope distribution in Azraq (degree) 38

Fig. 4.3: Drainage line und subcatchments in Azraq prepared based on a USGS DEM (30*30) 39

Fig. 4.4.a.b: Correlation between precipitation data of stations (F1-F4) and (F6-F9) 41

c: Correlation between recorded and calculated precipitation at F6 station. 41

Fig. 4.5: Rainfall stations and Thiesen Polygons in Azraq basin 42

Fig. 4.6: Yearly rainfall volume in Azraq basin for the period (1970-2013). 42

Fig. 4.7: Yearly runoff volume in Azraq basin for the period (1970-2013) 45

Fig. 4.8: Long-term average EVT0 in Azraq basin for every month 48

Fig. 4.9: Yearly groundwater recharge volume in Azraq basin for the period (1970-2013). 49

Fig. 5.1: Conceptual model for Azraq basin

Fig. 5.2: Model domain and boundary conditions

Fig. 5.3: Results of transient calibration, observed versus calculated groundwater head monitoring wells $\quad 58$

Fig. 5.4: Results of transient calibration, observed versus simulated springs discharge 59

Fig. 5.5: Water balance of the steady-state model $\quad 59$

Fig. 6.1: GIS model's domain, investigated area for MAR $\quad 70$

Fig. 6.2: Aquifer' saturated thickness in the investigated area 71

Fig. 6.3: Depth to groundwater in the investigated area 71

Fig. 6.4: Soil Texture in Azraq basin prepared after (Steinl, 2012) 75

Fig. 6.5: Soil Thickness in Azraq basin prepared after (Steinl, 2012)

Fig. 6.6: MAR suitability map based on slope in the investigated area 76

Fig. 6.7: MAR suitability map based on soil texture in the investigated area 76 
Fig. 6.8: MAR suitability map based on soil thickness in the investigated area

Fig. 6.9: Simulated groundwater mound for 8 scenarios of water volumes a,b,c: scenarios A1, A2, A3 81

Fig. 6.10: Simulated groundwater mound height against T values of Basalt aquifer, water scenarios $(1,2,3,4) \quad 82$

Fig. 6.11: Simulated groundwater mound height against T values of Basalt aquifer, water scenarios $(5,6,7,8) \quad 82$

Fig. 6.12: Simulated groundwater mound height against T values of the B45 aquifer, water scenarios $(1,2,3,4,8) 84$

Fig. 6.13: MAR suitability maps based on subsurface characteristics for different scenarios of $\mathrm{K}$ and collection capacity a: (calibrated K, $50^{\text {th }}$ percentile of Runoff), b: (calibrated K, $8^{\text {th }}$ percentile of Runoff), c: $(50 \%$ calibrated K, $50^{\text {th }}$ percentile of Runoff) d: (50\%calibrated K, $80^{\text {th }}$ percentile of Runoff) 86

Fig. 6.14: Suitability degrees for MAR implementation based on subsurface characteristics 87

Fig. 6.15: MAR suitability maps based on surface characteristics 88

Fig. 6.16: Final MAR suitability maps based on surface and subsurface characteristics 89

Fig. 6.17: Locations of proposed MAR structures in the study area. 90

Fig. 7.1: Abstraction rate of pumping scenario One 92

Fig. 7.2: Simulated groundwater head under pumping scenario One. 93

Fig. 7.3 Simulated groundwater head under the safe yield scenario 93

Fig. 7.4: AHP hierarchy for the decision of abstraction rate from the basin 101 


\section{Tables}

Table 2.1: Land use in Azraq basin (Ministry of Agriculture, 1993) 8

Table 2.2: Description of the general lithology in Azraq basin (Margane et al. 2002) 11

Table 2.3: Results of pumping tests for the Shallow Aquifer System (Arabtech, 1994). 17

Table 2.4: Results of pumping tests for the Middle Aquifer System (Arabtech, 1994). 18

Table 2.5: Relative changes in precipitation at F4 and F9 rainfall stations. 21

Table 2.6: Absolute historical change in temperature in each month for F0009 station. 21

Table 3.1: MAR schemes (Gale, 2005). 26

Table 3.2: Acceptable ranges of TDS values for different purposes (MWI and GTZ, 2004) 32

Table 3.3: Weighting values of suitability criteria provided by Gaur et al. (2011), Ghayoumian et al. (2007) and Saraf \& Choudhury (1998)

Table 3.4: Suitability ranges of depth to groundwater suggested by 5 studies. 35

Table 4.1: Wadis' Curve Numbers and Thiessen Polygon shares in Azraq basin 44

Table 4.2: Long term average of rainfall and groundwater recharge ( $\mathrm{mm} /$ year) for Azraq basin's wadis $\quad 50$

Table 5.1: Calibrated hydraulic conductivity and specific yield of the shallow and middle aquifers 57

Table 5.2: Composite sensitivity of K and Sy values for the Shallow Aquifer System 61

Table 6.1: 50th and 80th percentile of monthly surface runoff (MCM) in some wadis of the study area. 66

Table 6.2: Description of main scenarios for the simulations of groundwater mound. 68

Table 6.3: Suitability criteria for the factor 'depth to groundwater' $\quad 70$

Table 6.4: Suitability classes and scores of surface factors $\quad 74$

Table 6.5: Suitability classes, given weights and final suitability of surface factors $\quad 78$

Table 6.6: Suitability classes, given weights and final suitability of surface and subsurface factors $\quad 79$

Table 6.7: Catchment areas of proposed MAR structures and respective 50th and 80th percentiles of monthly runoff

90

Table 7.1: Simulated groundwater table decline by the year 2045 at monitoring wells under different pumping scenarios

Table 7.2: Future rate of groundwater table decline by the year 2045 at monitoring wells under different pumping scenarios 94

Table 7.3: Percentage of remaining aquifer' saturated thickness by the year 2045 at monitoring wells under different pumping scenarios $\quad 95$

Table 7.4: Simulated groundwater table decline by the year 2045 under pumping and MAR scenarios $\quad 97$

Table 7.5: Scale of relative importance for AHP method 99

Table 7.6: Pairwise comparison of criteria under 'Willingness \& Ability' scenario 104

Table 7.7: Preference matrix of criteria under 'Willingness \& Ability' scenario 105

Table 7.8: Pairwise comparison of criteria under 'Suffering of the Weak' scenario 106

Table 7.9: Preference matrix of criteria under 'Suffering of the Weak and the Environment' scenario 107

Table 7.10: Simulated average groundwater table decline by the year 2045 corresponding to management alternatives $\quad 108$

Table 7.11: Preference matrix of alternatives with respect to the criterion 'Aquifer Storage' 109

Table 7.12: Preference matrix of alternatives with respect to the criterion 'Biodiversity' 109

Table 7.13: Preference matrix of alternatives with respect to the criterion 'Income from Agriculture' 109

Table 7.14: Preference matrix of alternatives with respect to the criterion 'Income from Tourism' 110

Table 7.15: Preference matrix of alternatives with respect to the criterion 'Fuel Cost' 110

Table 7.16: Preference matrix of alternatives with respect to the criteria 'Job Availability' and 'Farmers Acceptance'

110

Table 7.17: Global and total priorities of alternatives under 'Willingness \& Ability' scenario 111

Table 7.18: Global and total priorities of alternatives under 'Suffering of the Weak and the Environment' scenario 


\section{Summary}

Natural groundwater replenishment in (semi-) arid areas is low and can be sometimes negligible as a result of low precipitation rates and high evapotranspiration. Therefore, groundwater resources in these areas can be considered as non-renewable. Due to increasing demand for water, aquifer systems have been subject to an over-abstraction depleting fossil water resources and causing numerous negative impacts; declining groundwater table and aquifer storage, salt water intrusion, land subsidence and other problems. Additionally, the disappearance of wetlands in many areas in the world has been associated with groundwater over-abstraction which constitutes a significant ecological lost. The Azraq oasis located in the heart of the desert in Jordan is an example of the degradation of an important ecosystem as a result of groundwater over-abstraction.

Azraq basin is characterized by high heterogeneity in groundwater recharge, where the main recharge area is in the north of the basin. The central part of the basin is covered by wetland known as the Azraq Oasis containing a wealthy biodiversity. Abstraction for agricultural and domestic purposes occur mainly around the oasis area, leading to drastic decline of groundwater table. In this study different management solutions for the basin including pumping strategies and application of Managed Aquifer Recharge are analyzed.

A groundwater model is first built and calibrated for the Azraq basin in order to understand the response of groundwater table at the oasis area to pumping practices as well as to remote groundwater recharge, and predict its behavior under possible future scenarios and management alternatives.

The application of Managed Aquifer Recharge (MAR) is then discussed with a focus on the analysis of subsurface characteristics which play the main role in determining the ability of an aquifer to accommodate a specific amount of infiltrated water. A new approach of employing numerical groundwater modeling in the generation of MAR suitability maps in terms of sub-surface characteristics is presented. A number of model-runs are conducted to simulate groundwater table's response at different locations of the aquifer for different scenarios of infiltration water volumes. Simulation results are employed to calibrate an empirical equation that calculates the height of groundwater mound as a function of aquifer transmissivity and volume of infiltrated water, for a certain value of aquifer' specific yield, a certain range of vertical hydraulic conductivity, and fixed design and operation conditions of MAR structure. 
This empirical equation is applied in GIS to spatially calculate the height of groundwater mounding beneath a hypothetical MAR structure, and generate based on that suitability maps for MAR implementation. Suitability maps are generated for different scenarios of aquifer's hydraulic conductivity and assuming MAR structures capture the $50^{\text {th }}$ and $80^{\text {th }}$ percentile of monthly amount of surface runoff at the respective wadi in the study area.

Three surface factors are investigated in the basin for their suitability for MAR implementation; slope, soil texture and soil thickness, to generate a MAR suitability map in terms of surface factors where a new decision system is proposed for the integration of factors.

Based on MAR suitability map three MAR structures were proposed in the basin. MAR scenarios along with a number of pumping scenarios were tested using the calibrated groundwater flow model. The calibrated model was also used to define the safe yield of the aquifer and predict the behavior of the aquifer under scenarios of climate change.

The results show that by the year 2045 groundwater decline will range between 15 and 25 meters if current pumping practices continue. The safe yield of the aquifer where the groundwater table stabilizes was found to be $70 \%$ less than current pumping rates, indicating that the aquifer is being exploited largely beyond its limits. Two scenarios of future groundwater recharge, where recharge rates were reduced $25 \%$ and $50 \%$, were tested. Under these two scenarios, negligible impacts on the groundwater table in the oasis area were realized indicating that the aquifer can be considered as non-renewable.

The results show that the application of MAR in the basin doesn't contribute greatly to increasing the safe yield. Under MAR scenario where the capacity of MAR dam is designed based on the $50^{\text {th }}$ and $80^{\text {th }}$ percentiles of monthly surface runoff, groundwater head will increase 0.7 and $1 \mathrm{~m}$ by the year 2045 respectively.

Finally, a multi-criteria analysis was conducted for choosing abstraction rate in the basin based on conflicting environmental and socio-economic criteria under two scenarios of the future development of economic and other demographic issues.

the safe yield scenario was found to be the alternative that contributes the most to the goal of choosing the abstraction rate in the basin for the scenario of future economic prosperity, while keeping the current pumping rate was found to be the best alternative under a scenario of poor economic and social awareness. 


\section{Zusammenfassung}

Die natürliche Grundwasserneubildung in (semi-) ariden Gebieten ist aufgrund des geringen Niederschlags und der hohen Evapotranspiration niedrig und kann deshalb oft vernachlässigt werden. Daher können die Grundwasserressourcen in diesen Regionen als nicht-erneuerbar bezeichnet werden. Aufgrund der steigenden Nachfrage nach Wasser sind Aquifer Systeme oft Gegenstand übermäßiger Entnahme fossiler Wasserressourcen. Dies bringt zahlreiche negative Folgen wie sinkende Grundwasserstände, Salzwasser Intrusionen, Bodensenkung und weitere Probleme mit sich. Des Weiteren wurde das Verschwinden von Feuchtgebieten in vielen Regionen der Welt und der hiermit einhergehende ökologische Verlust mit der übermäßigen Entnahme von Grundwasser in Verbindung gebracht. Die AzraqOase, gelegen im Herzen der Jordanischen Wüste, ist ein Beispiel für diese der übermäßigen Grundwasserentnahme geschuldeten Ökosystemdegradierung.

Das Azraq Becken zeichnet sich durch eine stark heterogene Grundwasserneubildung aus, wobei die größte Neubildung im Norden des Beckens stattfindet. Im zentralen Becken befindet sich das Feuchtgebiet der Azraq-Oase mit ihrer hohen Biodiversität. Die Entnahme für Haushalte und die Landwirtschaft findet hauptsächlich hier statt und führt $\mathrm{zu}$ drastisch abfallenden Grundwasserständen. In dieser Studie werden verschiedene Management Lösungen für das Becken inklusive Pump-Strategien und die Anwendung von Managed Aquifer Recharge analysiert.

Zunächst wird ein Grundwassermodel für das Asraq Becken erstellt und kalibriert um die Reaktion des Grundwasserstandes im Oasen-Gebiet auf die Pump Praktiken und auf ferne Grundwasserneubildung zu verstehen, und das Verhalten auf verschiedene Zukunftsszenarien und Management Alternativen vorherzusagen.

Die Anwendung von Managed Aquifer Recharge (MAR) wird dann diskutiert mit einem Fokus auf die Analyse der Untergrundeigenschaften, die entscheidend sind für die Bestimmung der Fähigkeit eines Grundwasserleiters, eine bestimmte Menge von infiltriertem Wasser aufzunehmen. Ein neuer Ansatz zur numerischen Grundwassermodellierung bei der Erzeugung von MAR-Eignungskarten in Bezug 
auf Untergrundeigenschaften (Tiefe-zu-Grundwasser, Aquifer-Transmissivität, spezifische Ergiebigkeit) wird vorgestellt.

Eine Reihe von Modellläufen werden durchgeführt, um die Reaktion des Grundwasserspiegels an verschiedenen Stellen des Aquifers für verschiedene Szenarien von Infiltrationswasservolumen $\mathrm{zu}$ simulieren. Die Simulationsergebnisse werden verwendet, um eine empirische Gleichung zu kalibrieren, die, die Höhe des Grundwassermoments als Funktion der AquiferDurchlässigkeit und des Volumens des infiltrierten Wassers für einen bestimmten Wert der Aquifer-spezifischen Ergiebigkeit berechnet, einen bestimmten Bereich der vertikalen hydraulischen Leitfähigkeit und festen Entwurf und Betriebsbedingungen der MAR-Struktur.

Diese empirische Gleichung wird im Geoinformationssystem (GIS) verwendet, um räumlich die Höhe der Grundwassererhöhung unter einer hypothetischen MARStruktur zu berechnen und auf dieser Grundlage Eignungskarten für die MARImplementierung zu erzeugen. Eignungskarten werden für verschiedene Szenarien der hydraulischen Leitfähigkeit des Aquifers erzeugt und unter der Annahme, dass MAR-Strukturen das 50. und 80. Perzentil des monatlichen Oberflächenabflusses am jeweiligen Wadi im Untersuchungsgebiet erfassen.

Drei Oberflächenfaktoren werden im Becken auf ihre Eignung zur MARImplementierung untersucht; Steigung, Bodenbeschaffenheit und Bodendicke, um eine MAR-Eignungskarte in Bezug auf Oberflächenfaktoren zu erzeugen, wo ein neues Entscheidungssystem zur Integration von Faktoren vorgeschlagen wird.

Basierend auf der MAR-Eignungskarte wurden drei MAR-Strukturen im Becken vorgeschlagen. MAR-Szenarien mit einer Reihe von Pump-Szenarien wurden mit dem kalibrierten Grundwasserströmungsmodell getestet. Das kalibrierte Modell wurde auch verwendet, um die sichere Ergiebigkeit des Grundwasserleiters zu definieren und das Verhalten des Grundwasserleiters unter Szenarien des Klimawandels vorherzusagen.

Die Ergebnisse zeigen, dass die Grundwasserabsenkung im Jahr 2045 zwischen 15 und 25 Metern liegen wird sollten die aktuellen Pump Praktiken beibehalten werden. Die sichere Entnahmemenge des Aquifers bei welcher sich der Grundwasserspiegel stabilisieren würde wäre $70 \%$ niedriger als die aktuellen 
Pumpraten. Dies deutet darauf hin, dass der Aquifer heute deutlich über die übernutzt wird. Es wurden zwei Zukunftsszenarien getestet wobei die Neubildungsrate einmal um 25\% und einmal um 50\% reduziert wurde. In beiden Szenarien wurde festgestellt, dass die Variation der Neubildungsrate auf den Grundwasserspiegel in der Oase einen vernachlässigbaren Einfluss hat und der Aquifer somit als nicht-erneuerbar betrachtet werden kann.

Die Ergebnisse zeigen weiterhin, dass die Anwendung von MAR in dem Becken zu einem gewissen Maß zur Erhöhung der sicheren Entnahmemenge beiträgt. In dem MAR Szenario bei welchem die Kapazität des MAR Dammes basierend auf dem fünfzigsten und achtzigsten Perzentil des monatlichen Oberflächenabflusses erstellt wurde, erhöhte sich der Grundwasserstand um 0.7 bzw. 1 m.

Zum Schluss wurde eine Multifaktorenanalyse durchgeführt um die Entnahmemenge im Becken, basierend auf umwelt- und sozioökonomischen Kriterien, in zwei verschieden Zukunftsszenarien bezüglich ökonomische und demographischer Entwicklung, zu bestimmen.

Es wird festgestellt, dass die Festlegung einer sicheren Entnahmerate die Beste alternative im Fall einer positiven sozioökonomischen Entwicklung ist. Im Fall einer negativen sozioökonomischen Entwicklung stellt sich das Beibehalten der aktuellen Pumpraten als beste Alternative heraus. 


\section{Introduction}

\subsection{General overview}

Jordan is a water scarce country that has been suffering from an enduring water deficit since 1960s. The majority of the county fall in climatic zones ranging from semiarid climate of a Mediterranean type to desert climate where most of the kingdom (about 87\%) receives annually less than $200 \mathrm{~mm}$ of rainfall (MWI and GTZ, 2003).

Water demand has increased in Jordan in the different sectors due to the escalating population caused by influx of refugees from neighboring countries, coupled with urbanization and industrialization growth, putting more pressure on available water resources, and decreasing annual per capita share of potable water from 3600 $\mathrm{m}^{3} /$ year in 1946 to only $145 \mathrm{~m}^{3} /$ year in recent years (RWC, 2009).

Because of the unsuitability of the majority of Jordan' scarce surface water, groundwater is the main water source of the country. Precipitation is the main source for groundwater recharge. A large share of precipitation is lost by evaporation (92\%) leaving a small portion for groundwater replenishment $(5 \%$ which is around $395 \mathrm{MCM} / \mathrm{year})$. The rest (3\%) goes as surface flow. Jordan's groundwater receives inflow from shared water resources along the borders with Syria, which is estimated at $68 \mathrm{MCM} /$ year. Additionally, irrigation leaks from pipes, reservoirs, wastewater treatment plants all contribute to return flows estimated at $70 \mathrm{MCM} /$ year. As a result, the total amount of inflow is estimated at $533 \mathrm{MCM} / \mathrm{year}$.

On the other hand, groundwater abstraction by wells and springs was 420 MCM/year in 2002. The amount of baseflow draining into stream courses in wadis is estimated at $197 \mathrm{MCM} /$ year. Consequently, the total amount of outflow is estimated at $637 \mathrm{MCM} /$ year.

By comparing the total inflow and total outflow, it is concluded that groundwater budget in Jordan is negative (change in storage is -104 MCM/year). This has led springs and baseflow to decrease, and groundwater table to decline posing problems on water quality represented by salinization (MWI and GTZ, 2008). 


\subsection{Research motivation and challenges}

Due to limited surface water resources in arid and semi-arid areas, groundwater constitutes the main source of water. Under arid conditions, the natural replenishment of aquifers is very low as a result of low precipitation rates and high evapotranspiration. Average groundwater recharge rates estimated over large (semi-) arid areas by Scanlon et al. (2006) range from 0.2 to $35 \mathrm{~mm} /$ year. High inter-annual variability of rainfall is another problem that prevails in arid and semiarid areas. These areas receive in some years very low precipitation, where in other years they receive unusually large amount of rainfall which goes mostly as losses.

In the last years, aquifer systems in (semi-) arid areas have been put under stress to meet the increasing demand in the different sectors depleting fossil water sources and causing numerous negative impacts. Declining groundwater table and aquifer storage, salt water intrusion, land subsidence and other problems have been documented in many studies as a consequence of groundwater over-draft (e.g. Zektser et al. 2005). Additionally, the disappearance of wetlands in many areas in the world has been associated with groundwater over-abstraction which constitutes a significant ecological lost (Millennium Ecosystem Assessment, 2005; RosetaPalman et al., 2015).

The Azraq oasis located in the heart of the desert in Jordan is an example of the degradation of an important ecosystem containing a wealth biodiversity as a result of groundwater over-abstraction. Azraq oasis is located in the center of Azraq basin that is characterized by high heterogeneity in precipitation ranging from over $500 \mathrm{~mm} /$ year at the north of the basin to less than $50 \mathrm{~mm} /$ year in the south and east.

As groundwater recharge in the center of the basin is very small, the water source of the oasis is mainly the recharge area at the north. Water travels in the basalt layer through channels along fault lines to reach the carbonate aquifer and be discharged through two springs that used to feed the oasis (Holber et al., 2001). Due to the shallow water table and good water quality at the center and the deep water table elsewhere in the basin, abstraction areas are not uniformly distributed. The majority of abstraction occurs in the farming area and through domestic governmental wells (AWSA wellfield) around the oasis. 
Abstraction rates has continuously increased since 1980, as a result, groundwater table declined substantially leading to the dry out of springs in 1990 (Mesnil and Habjoka, 2012). Groundwater table in the area has been declining at an average rate of $1 \mathrm{~m} /$ year (Goode et al. 2013), which compromises the future use of the aquifer and puts the oasis at the danger of completely disappearing.

A number of studies have been conducted proposing different solutions for the water crisis in the basin.

Groundwater flow model for the basins has been prepared in many studies (UNDPAzraq Oasis Conservation Project, 1996; Abdulla et al., 1999; Al-Kharabsheh, 2000; 2003; Abu-El-Sha'r and Hatamleh, 2007). The calibrated flow model was mainly applied to assess the future behavior of the aquifer under scenarios of reduced pumping rates, however, the extent to which such solutions are accepted socially and economically wasn't discussed.

Other studies suggested the implementation of Managed Aquifer Recharge (MAR) in the basin. GIS-based studies were conducted in the basin (Rapp, 2008; Alraggad and Jasem, 2010; Steinel, 2012) where suitable sites for MAR were assigned based on considerations and factors related to surface and subsurface characteristics.

A thorough review of the literature on MAR (Chapter 3) shows that the analysis of aquifer' storage capacity for artificial recharge has been limited in MAR studies, including those in Azraq basin. MAR site-selection has been based on a qualitative approach using variable and arbitrarily-chosen criteria with limited integration of hydrogeological factors.

Additionally, characteristics of rainfall, which is the source of artificial recharge, and its variability has been discussed to a limited extent. Water collection devices are designed usually based on the $50^{\text {th }}$ percentile of rainfall because of economic considerations. However, in arid and semi-arid areas and under conditions of climate variability larger percentiles could be justifiable.

A more integrated approach is needed where:

- The process of MAR sites selection is optimized based on a quantitative approach that analyses the aquifer' storage capacity 
- The characteristics and variability of rainfall are considered in the selection of MAR sites and collection capacity.

- MAR and other proposed alternative solutions (reduced pumping strategies) are assessed and compared, taking into account environmental and socioeconomic aspects.

\subsection{Objective}

The objective of this study is to draw conclusions on the problems that face groundwater resources in arid and semi-arid areas, and on the approaches and solutions that can be applied to alleviate these problems. A case-study is going to be executed in Azraq basin where the main components of the water cycle in the basin, i.e. precipitation, runoff, evapotranspiration and groundwater recharge are quantified and an understanding of the main challenges that face the basin as well as the dynamic of certain processes, e.g. precipitation and groundwater table, is gained.

A calibrated groundwater flow model is employed in this study to understand the response of groundwater table to pumping behavior and to groundwater recharge in order to predict the future impact of the current management practices, or other impacts imposed by climate change, and suggest accordingly effective management strategies. A special emphasis is given to the process of planning and implementing a MAR scheme under arid and semi-arid conditions.

The objective of the study can be summarized as follow:

- Quantify the water budget of the basin

- Build and calibrate a groundwater flow model for the basin.

- Provide a literature review on "MAR the state of the art" and summarize the criteria and factors of MAR design quoting from case-studies executed elsewhere.

- Propose a new quantitative approach for the selection process of MAR locations based on aquifer storage capacity.

- Propose a new decision system for the integration of MAR determinant factors

- Design a MAR scheme in the basin. 
- Investigate different scenarios of pumping strategies separately and in combination with MAR scenarios.

- Select the optimized solution that achieves the most suitable trade-off among environmental and socio-economic criteria.

\subsection{Thesis structure}

This thesis is divided into three main parts:

Part One, Chapters (1-3), is a general overview of the study area, including a description of main hydrological processes, hydrogeological system and the problems and challenges that are facing the Azraq basin, in addition to literature review on Managed Aquifer Recharge (MAR).

Jordan's water situation as well as research motivation and objective are discussed in Chapter One. Chapter Two provides a description of the study area (climate, hydrology, hydrogeology...). Chapter Three is a discussion on the application of MAR in arid and semiarid areas, where MAR-the state of the art is presented.

Part Two, Chapters (4-7), is on methodology of data acquisition and analysis, hydrogeological modeling, application of the model in MAR site selection and analysis of alternative solutions.

Chapter Four provides an explanation on data acquisition and processing, and demonstrate the water-cycle components in the basin (rainfall, evapotranspiration, runoff, and groundwater recharge) quantified based on acquired processed data.

Chapter Five describes the conceptual hydrogeological model in Azraq basin, numerical model set-up, parameterization and calibration.

In Chapter Six the model is applied in the selection of suitable sites for MAR based on aquifer characteristics and runoff amount and variability following a quantitative approach. Additionally, a new 'decision system' for the analysis of surface characteristics is presented. Potential locations for MAR structures are proposed based on basin' surface and subsurface characteristics.

Chapter Seven is on model application and decision making, where management strategies in the basin are analyzed. Scenarios of pumping strategies are applied separately and in combination with MAR scenarios. Aquifer behavior under 
possible shifts in groundwater recharge is simulated. Multi-criteria Analysis is applied using the Analytic Hierarchy Process (AHP) to analyze decision alternatives under conflicting environmental and socio-economic criteria.

Part Three, Chapter (8), is on conclusions where final all-encompassing results and recommendations are discussed. 


\section{Study area}

\subsection{Location and importance}

Azraq is a transboundary basin shared between Syria and Jordan (94\% of its area is located in Jordan and the rest in Syria), see Fig. 2.1. It has an area of $12414 \mathrm{Km}^{2}$ stretching from the lava peaks of Jebel Druze in the south of Syria to Wadi Sirhan in the north of Saudi Arabia with coordinates of 250 to $400 \mathrm{E}$ and 055 to $230 \mathrm{~N}$ Palestine Grids (MWI and GTZ, 2003).

Azraq basin represents one of the high potential groundwater basins in Jordan supplying three major cities; Amman, Zerqa and Irbid. The basin is very rural and has only about 29000 inhabitants (Mesnil and Habjoka, 2012). The largest towns are Azraq and Umm Al Qettein with $<6000$ inhabitants each located in the center of the basin.

Until early 1990s the central part of this basin was covered by a huge wetland containing a wealth biodiversity and some of the rarest habitats in the region. The presence of such wetland in a fragile environment gave the area special importance for migratory birds with more than a million birds utilizing it during migration season (Al-Kharabsheh, 1995).

\subsection{Landuse}

The majority of the basin is covered with basalt rocks, chert plains and alluvial deposits (more than 96\%) along with some agricultural activities. As it can be seen from Fig. 2.2 the farms are concentrated in three main areas: Around azraq town in the center of the basin, north badia, and Jiza in the west.

Huber (2010) estimates the agricultural area to be around $290 \mathrm{~km}^{2}(\sim 2.3 \%$ of the basin area). The main landuse of Azraq in 1993 is shown in Table 2.1.

The area of irrigated farms has increased a thousand fold since the early 1970s. 

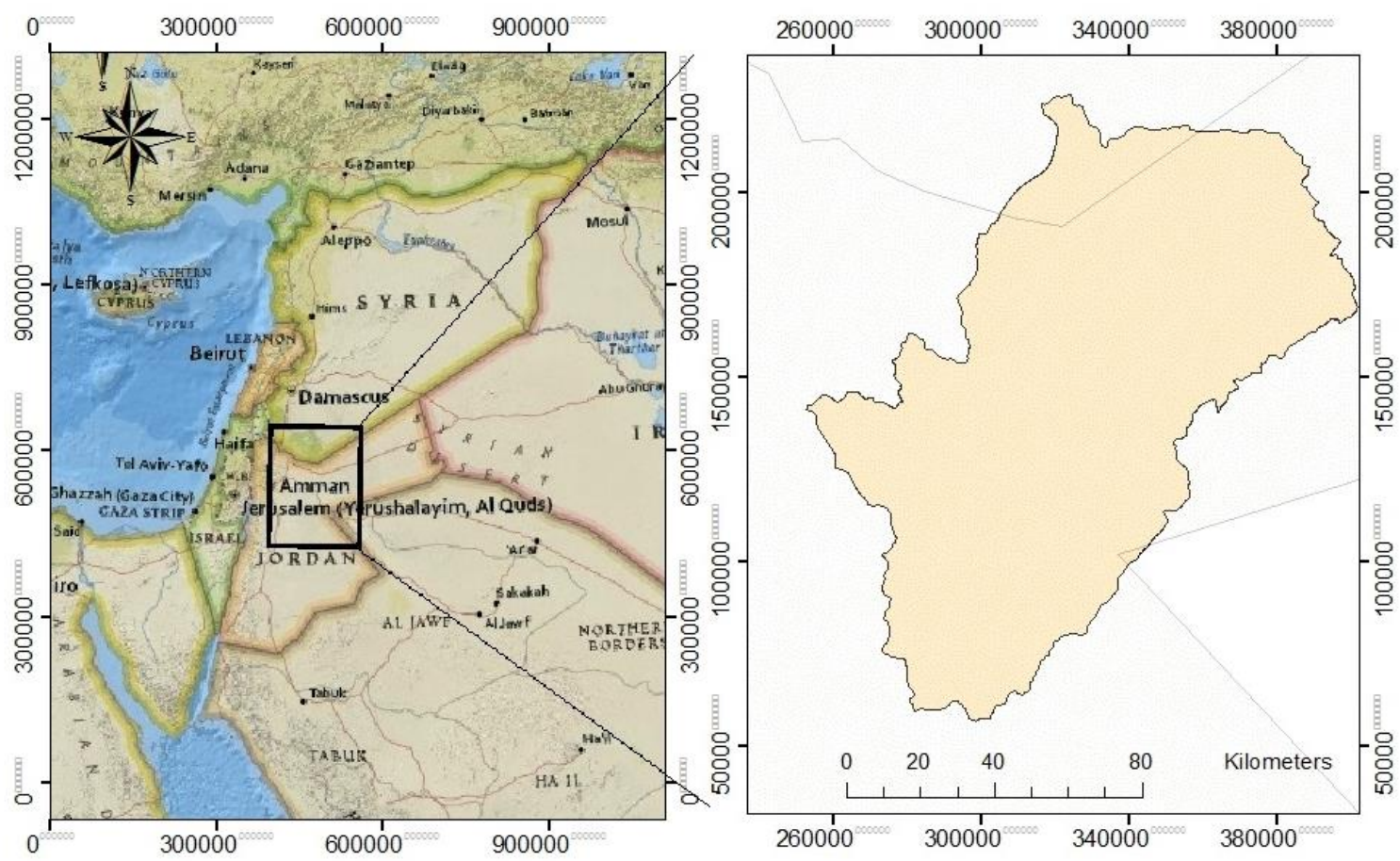

Fig. 2.1: Location of Azraq basin, (National Geographic, ESRI).

Table 2.1: Land use in Azraq basin (Ministry of Agriculture, 1993)

\begin{tabular}{|l|l|l|}
\hline Land Use & Area $\left.\mathbf{( k m}^{\mathbf{2}}\right)$ & Area $(\mathbf{\%})$ \\
\hline Irrigated Vegetables, Cereals & 2.3 & 0.02 \\
\hline Irrigated Fruit Trees & 7.9 & 0.07 \\
\hline Irrigated Non-Deciduous Trees & 17.9 & 0.16 \\
\hline Rainfed Fruit Trees & 0.7 & 0.01 \\
\hline Rainfed Non-Deciduous Trees & 0.6 & 0.01 \\
\hline Rainfed Vegetables, Cereal & 2.3 & 0.02 \\
\hline Natural Vegetation, Steppe & 47.67 & 0.41 \\
\hline Urban and Bare Rock & 11335.2 & 99.30 \\
\hline
\end{tabular}

\subsection{Geology}

\subsubsection{Stratigraphy}

Formations found in Azraq include Quaternary formations (Basalt that outcrops in the north of the basin, and Alluvium deposits which are found in the center of the 


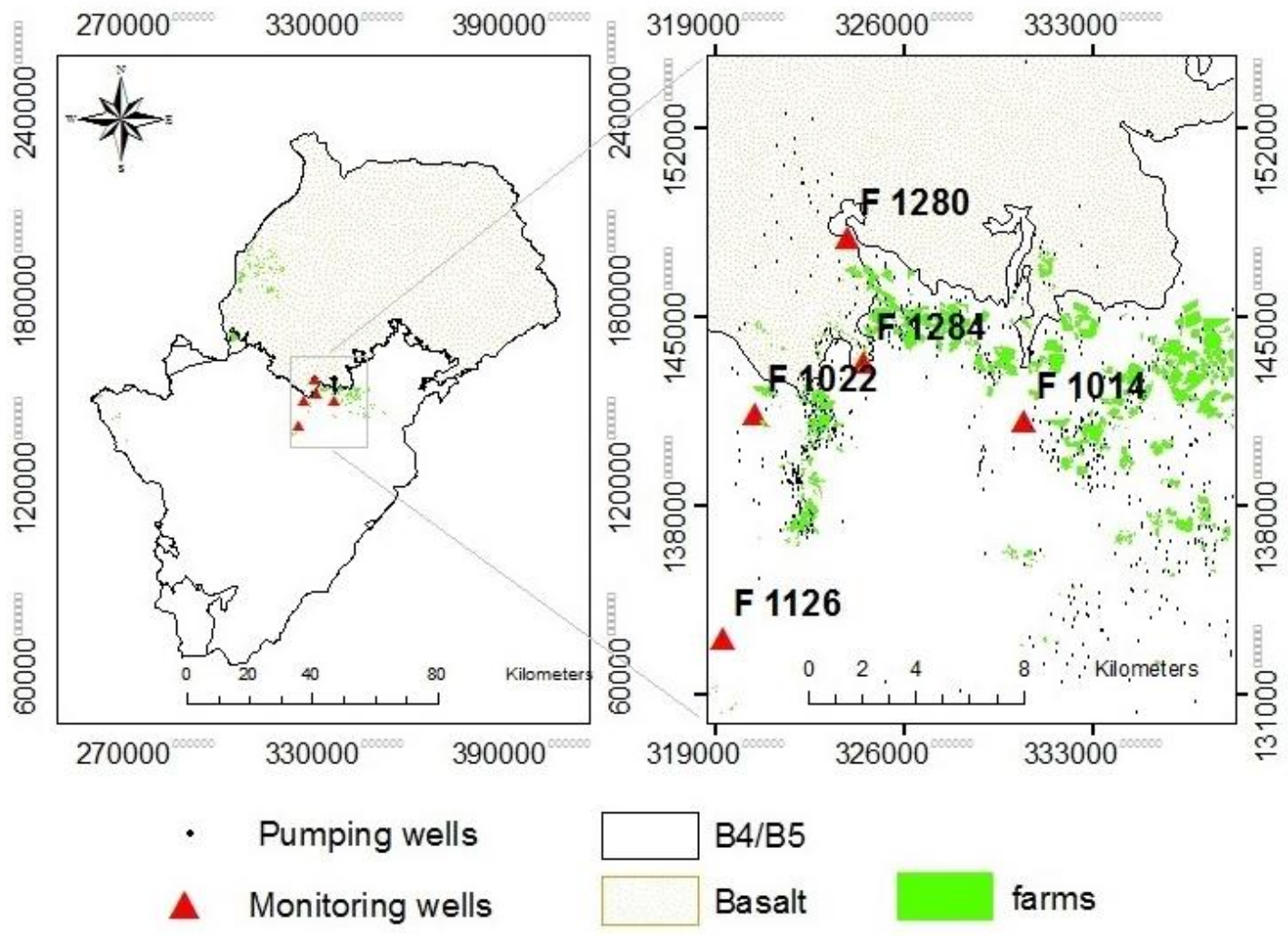

Fig. 2.2: Outcropping aquifers, farms, pumping and monitoring wells in Azraq basin prepared based on data from (MWI, 2013)

basin), Tertiary formations (Rijam (B4) and W.shalla (B5) which outcrop central and south of the basin.

Late cretaceous rocks in the basin are divided into two groups (Belqa groups that has the Muaqar (B3), Amman (B2), Ruseifa (B1) formations, and Ajlun group that has the (Wasi es sir formation (A7), Shueib (A5/6), Hummar (A4), Fuheis (A3), Nau'r (A1/2)) formations.

Early cretaceous formations are locally known as Kurnub group and are composed of two main formations: Subrihi (K2) and Arda (K1).

Geological cross section in Azraq basin is shown in Fig. 2.3b. Table 2.2 provides a description of the general lithology, thickness and other information on the formations. 


\subsubsection{Geological structure}

There are two main fault systems in Azraq, one trending E-W and the second NWSE. Fig. 2.3a shows the main faults in the basin.

- Swaqa Fault zone with a length of about $200 \mathrm{~km}$ crosses the Jordan platform from the dead sea Garben in the west to Saudi-Arabia in the east. The deformation associated with this fault zone comprises small drag folds in the cretaceous-tertiary.

- Ramtha-Wadi Sirhan Fault zone, which is the most important fault system in Azraq. It comprises a complex series of faults extending for $325 \mathrm{~km}$ from Ramtha in the NW to Saudi Arabia in the SE. This fault is responsible for the Hamza and Azraq Garbens in Jordan located southeast of Azraq town.

- Fulk Fault: represents the eastern flank of the Hamza Garben and the associated structural depression south and southeast of the Azraq town. Vertical displacement along this fault reaches up to more than $3000 \mathrm{~m}$.

- Qa'a Abu Husain Fault: Located in the Basalt Plateau in the northeast of the basin. It has a length of about $140 \mathrm{~km}$ in Jordan, and extends northeast wards into Syria and southwest into Saudi Arabia (El-Naqa et al., 2010).

\subsection{Hydrogeology}

\subsubsection{Classification of Aquifer systems in Jordan}

Consolidated and unconsolidated types of aquifers exist in Jordan. Unconsolidated aquifers, like the fluvial deposits in the Jordan Valley, are of minor importance. Bedrock aquifers prevail in the majority of the country and form the main groundwater source (MWI and GTZ, 2008).

The main bedrock aquifers are:

- Sandstone aquifers like the Ram sandstone aquifer ("Disi-aquifer") and the Kurnub aquifer

- Carbonate aquifers like A7/B2 and B4/B5 aquifers

- Basalt aquifer 
Based on the spatial distribution, lithology and age of geological units, the aquifers in Jordan are classified into three main systems (MWI and GTZ, 2008).

- Ram-Zarqa-Kurnub Aquifer System: It includes the Ram aquifer (Cambrian and Ordovician periods), the Khreim aquitard (Silurian period), the Zarqa aquifer (permian jurassic and Triassic) and the Kurnub aquifer (lower cretaceous).

- Upper Cretaceous Limestone Aquifer System: It includes the A1/2 aquifer, the A3 aquitard, the A4 aquifer, the A5/6 aquitard and the B2/A7 aquifer.

- Tertiary-Quaternary Shallow Aquifer Systems: They include the B3 aquitard, the B4/5 aquifer, the Basalt aquifer and the alluvial deposits.

Table 2.2: Description of the general lithology in Azraq basin (Margane et al. 2002)

\begin{tabular}{|c|c|c|c|c|c|c|c|}
\hline Epoch & Group & Formation & Symbol & Rock type & $\begin{array}{l}\text { Thickness } \\
\text { m }\end{array}$ & $\begin{array}{l}\text { Aquifer } \\
\text { potentiality }\end{array}$ & Permeability $\mathrm{m} / \mathrm{s}$ \\
\hline \multirow[t]{2}{*}{ Quaternary } & \multirow{2}{*}{$\begin{array}{l}\text { Jordan } \\
\text { Valley }\end{array}$} & Wadi Fill & All & Soil, Sand and Gravel & $10-40$ & Good & $2.4 \times 10-7$ \\
\hline & & Basalt & $\mathrm{V}$ & Basalt. Clay & & Good & \\
\hline \multirow[t]{2}{*}{ Tertiary } & \multirow[t]{5}{*}{ Belqa } & Wadi Shallala & B5 & $\begin{array}{l}\text { Chalk, marly limestone } \\
\text { with gluconite }\end{array}$ & $0-555$ & Good & \\
\hline & & Umm Rijam & B4 & Chert and limestones & $0-311$ & Good & \\
\hline \multirow[t]{8}{*}{$\begin{array}{l}\text { Upper } \\
\text { Cretaceous }\end{array}$} & & Muwaqqar & B3 & $\begin{array}{l}\text { Chalk, marl and Chalky } \\
\text { limestone }\end{array}$ & $60-70$ & poor & \\
\hline & & Amman & B2 & $\begin{array}{l}\text { Chert, limestone with } \\
\text { phosphate }\end{array}$ & $80-120$ & Excellent & $10-5-3 \times 10-4$ \\
\hline & & Ghudran & B1 & $\begin{array}{l}\text { Chalk, Marl and Marly } \\
\text { limestone }\end{array}$ & $15-20$ & poor & \\
\hline & \multirow[t]{5}{*}{ Ajloun } & Wadi Sir & A7 & $\begin{array}{l}\text { Hard Crystalline } \\
\text { Limestone. Dolomitic } \\
\text { and Some Chert }\end{array}$ & $90-110$ & Excellent & $1 \times 10-7-1 \times 10-4$ \\
\hline & & Shueib & A5-6 & $\begin{array}{l}\text { Light Grey limestone } \\
\text { interbeded with Marls } \\
\text { and Marly Limestone }\end{array}$ & $75-100$ & $\begin{array}{l}\text { fair to } \\
\text { poor }\end{array}$ & $\begin{array}{l}6.3 \times 10-5-7.2 \\
\times 10-4\end{array}$ \\
\hline & & Hummar & A4 & $\begin{array}{l}\text { Hard dense limestone } \\
\text { and Dolomitic } \\
\text { Limestone }\end{array}$ & $40-60$ & good & $\begin{array}{l}8.1 \times 10-7-7.6 \\
\times 10-4\end{array}$ \\
\hline & & Fuheis & A3 & $\begin{array}{l}\text { Gary and Olive Green } \\
\text { soft Marl. Marly } \\
\text { limestone and } \\
\text { limestone }\end{array}$ & $60-80$ & poor & $\begin{array}{l}5.3 \times 10-7-1.7 \\
\times 10-5\end{array}$ \\
\hline & & Na'ur & A1-2 & $\begin{array}{l}\text { Limestone interbeded } \\
\text { with a thick sequence } \\
\text { of Marl and Marly } \\
\text { Limestone }\end{array}$ & $150-220$ & poor & $\begin{array}{l}2 \times 10-8-3.1 \times \\
10-5\end{array}$ \\
\hline \multirow[t]{2}{*}{$\begin{array}{l}\text { Lower } \\
\text { Cretaceous }\end{array}$} & \multirow[t]{2}{*}{ Kurnub } & Subeihi & $\mathrm{K} 2$ & \multirow{2}{*}{$\begin{array}{l}\text { Massive White and } \\
\text { Varicolored Sandstone } \\
\text { with layers of Reddish } \\
\text { Silt and Shale }\end{array}$} & \multirow[t]{2}{*}{300} & \multirow[t]{2}{*}{ good } & \multirow[t]{2}{*}{$\begin{array}{l}6.9 \times 10-3-5.2 \times \\
10-2\end{array}$} \\
\hline & & Aarda & K1 & & & & \\
\hline
\end{tabular}




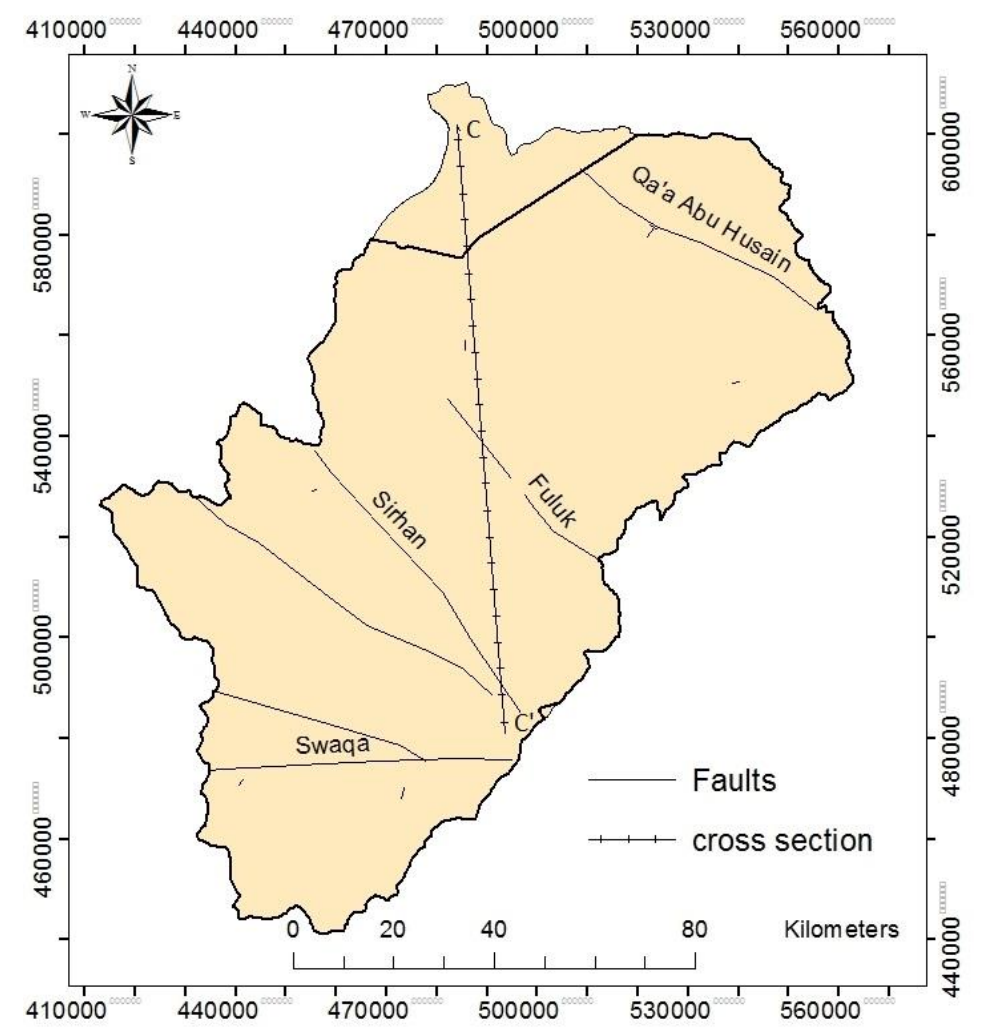

Fig. 2.3a: Faults and cross section in Azraq basin (MWI, 2013)

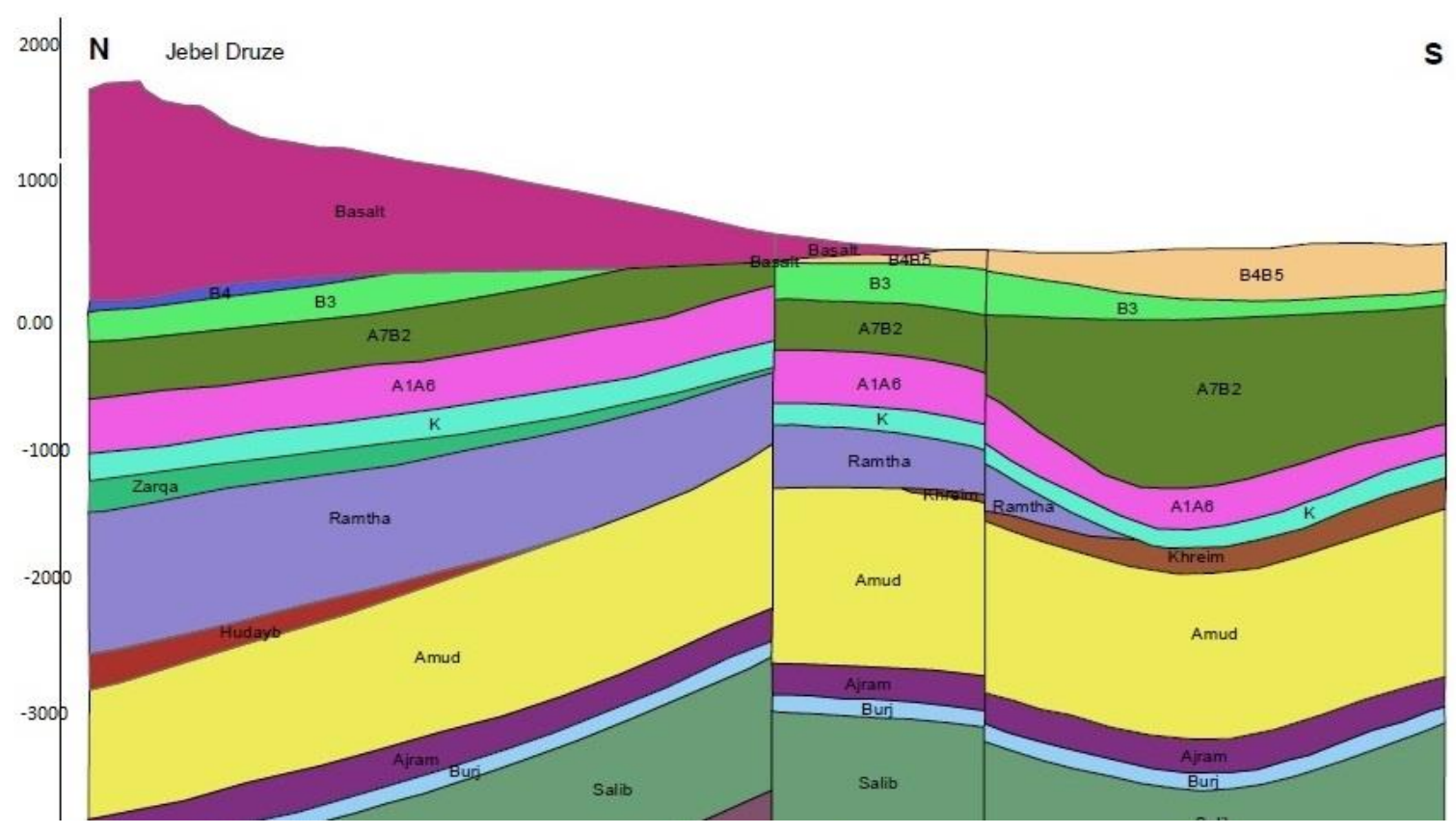

Fig. 2.3b: Geological cross section CC' (WAJ and BGR, 1994) 


\subsubsection{Aquifer systems in Azraq basin}

There are three main aquifer systems in Azraq, which are:

\subsubsection{1- The Upper Aquifer System}

is an unconfined aquifer consisting of four members hydraulically connected, which are Quaternary sediments, Basalt, Shallala (B5) and Rijam (B4). The Basalt aquifer covers the northern area of the basin and extends from Jabal-el Arab in Syria until the center of the basin, see Fig.2.4. Its thickness reduces gradually from north to south, and from east to west. It has the general feature of fractured aquifer. Its permeability is highly variable from area to another and is provided by joints, inter-connected vesicular holes and preferential flow paths which have developed in the basalt rocks (MWI and GTZ, 2008)

The B4/5 aquifer outcrops in the middle and south of the basin, see Fig.2.4. The lower part of this aquifer (Um-Rijam formation, B4) consists of limestone, chalky lime stone chalk and beds of chert. The appearance of marl and decrease of chert in the overlying Wadi-shalla formation defines the top of the B4 formation. The B5 formation contains marly clayly layers and acts as an aquitard in the north between the Basalt and B4 formation, while it consists of sandy layers in the south and act as an aquifer The physical and chemical characteristics as well as the depth to groundwater table in the shallow aquifer system are greatly different from one area to another (MWI and GTZ, 2008). The groundwater table is at a depth of more than $400 \mathrm{~m}$ in the north while it is very shallow in the central part and can be reached with wells of few meters deep. Therefore, many hand-wells have been dug in the area especially around the farms northeast of the Oasis (Fig. 2.2).

The recharge of the upper system aquifer occurs in the north and north east of the basin where the amount of rainfall exceeds $150 \mathrm{~mm} /$ year and to a higher degree in the Syrian part at the slopes of Jabal-el-Arab where the height of precipitation, including snowfall, exceeds $500 \mathrm{~mm} / \mathrm{year}$. As the amount of rainfall decreases drastically towards the south and the east of the basin, groundwater recharge is negligible in these areas. Groundwater flows southwards from recharge area north and north east of the basin through the Basalt and from south northwards through the B $4 / 5$ aquifer and meets in the central part where it is discharged through two springs. These springs had dried by 1990 as a result of over abstraction.

The limited spatial distribution of monitoring wells and the unavailability of continuous time series of head records makes it difficult to apply any spatial 
interpolation of water level in the basin. Fig. 2.6a shows groundwater contour map and flow pattern of the Upper Aquifer System arranged after (Hobler et al., 2001). Records of groundwater level fluctuation in the Upper Aquifer System are available at monitoring wells installed and controlled by the Ministry of Water and Irrigation, Jordan. No records are available before the year 1985, and a continuous uninterrupted time-series of groundwater head during the period stretching from 1985 until 2013 is available at only 2 monitoring wells (F1043, F1280) (MWI, 2013).

The sever abstraction of groundwater has led to the decline of water table in many wells in the basin and to the dry out of the main springs. Fig. 2.5 shows the records of groundwater level at F1280 monitoring well.

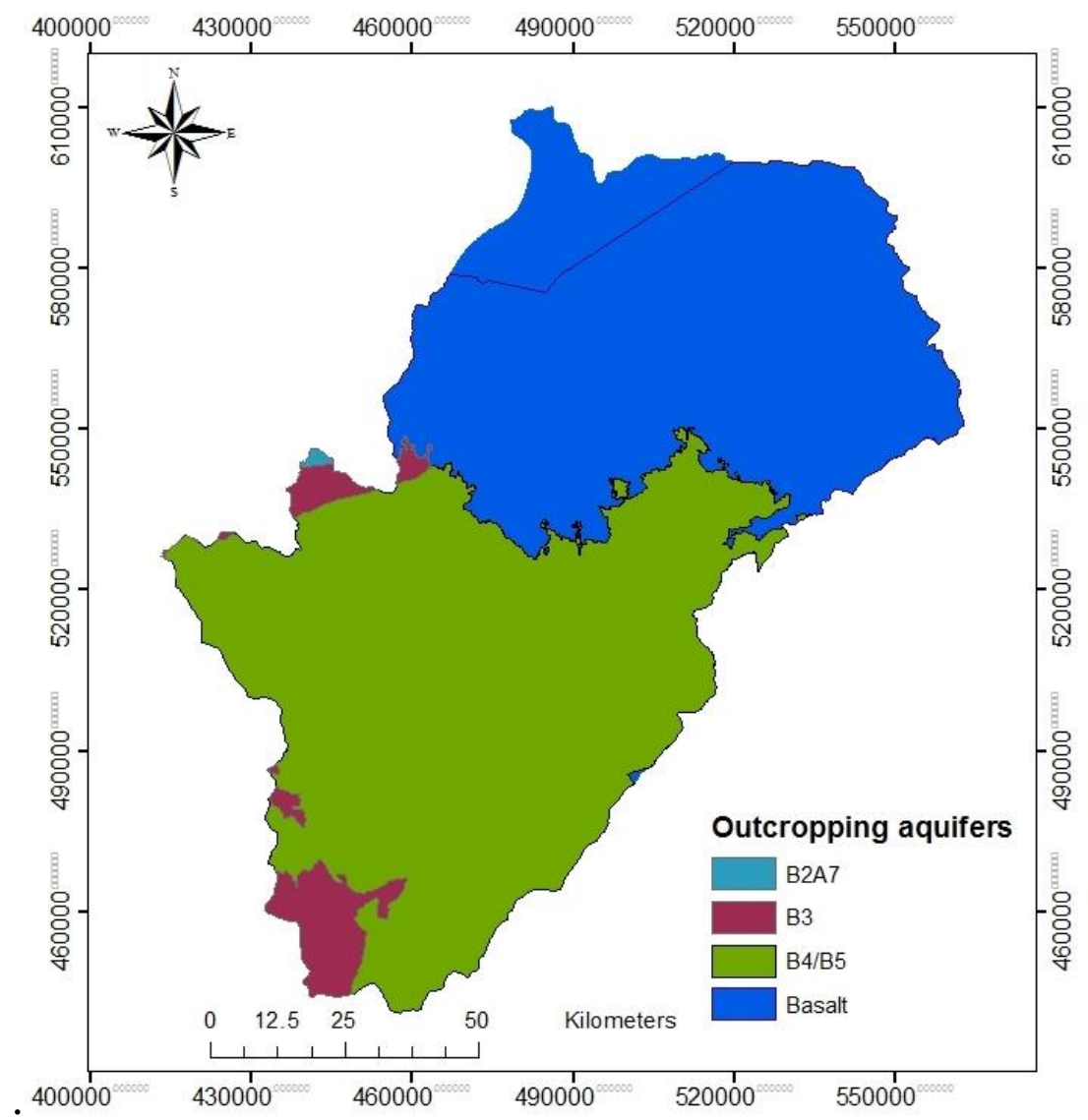

Fig. 2.4: Outcropping aquifers in Azraq basin 


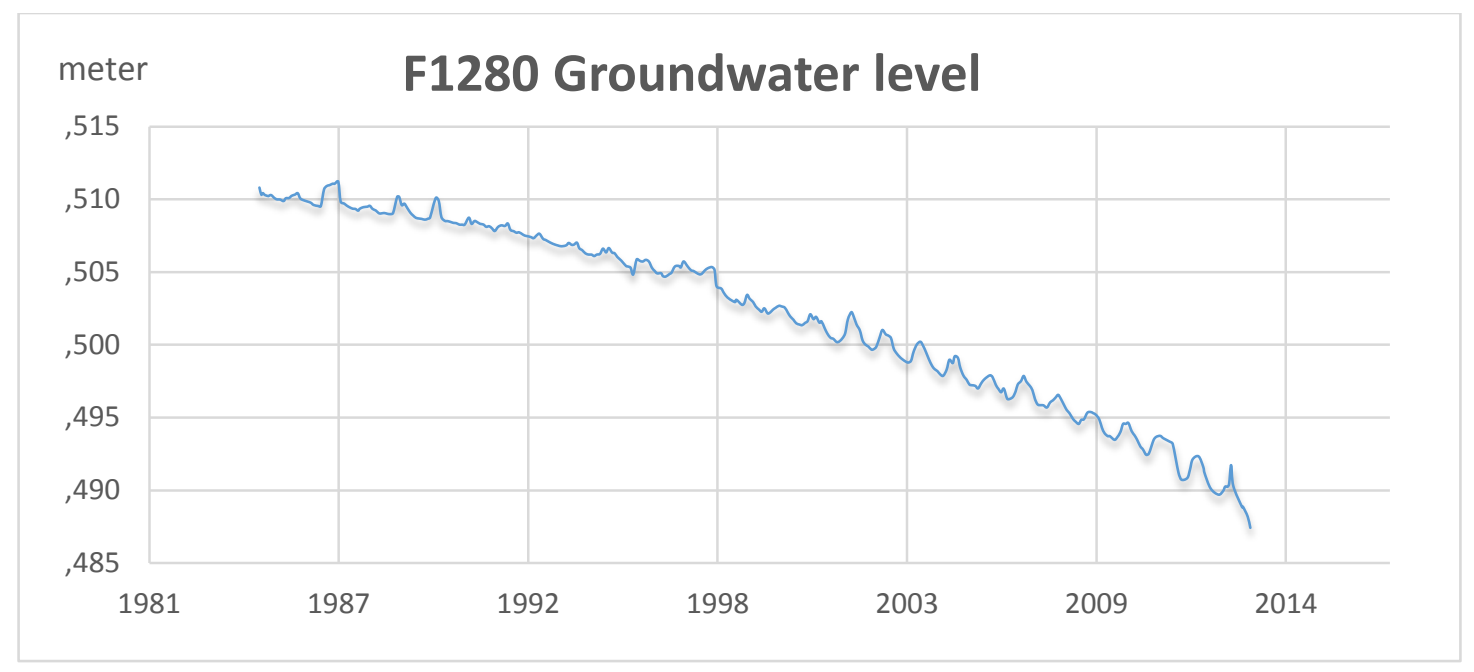

Fig. 2.5: Groundwater level at monitoring well F1280 (MWI, 2013)

\subsubsection{2-The Middle Aquifer System}

The low permeable marls and chalks B3 aquitard separates the Upper Aquifer System from the Middle Aquifer System. It consists of Wadi-Sir limestone formation (A7), and Amman-Silicified limestone and Al-hisa phosphorite formation (B2). B1 aquitard can exist sometimes between A7 and B2 and hider the flow.

The B2/A7 aquifer is the most important aquifer system in Jordan. It has a very wide extent and has a relatively high permeability and storability. This aquifer doesn't outcrops in the Azraq basin, and exists at a large depth, therefore it is barely exploited. Recharge areas exist west and south of the basin in Jordan and north of the basin in Syria, and are characterized by high precipitation. Water flows from recharge areas in Jordan eastwards and northeastwards, and from recharge areas in Syria southwards. Fig 2.6.b shows groundwater contour map and flow pattern in the Middle Aquifer System arranged after (Hobler et al., 2001).

\subsubsection{Lower Aquifer System}

The Lower Aquifer System A6-1 is separated from the middle one by low permeability marls and marly limestone. It has a high variability in vertical permeability due to the presence of clay and marl layers. Underneath that comes the deep aquifer system (Kurnub and Zarqa). 


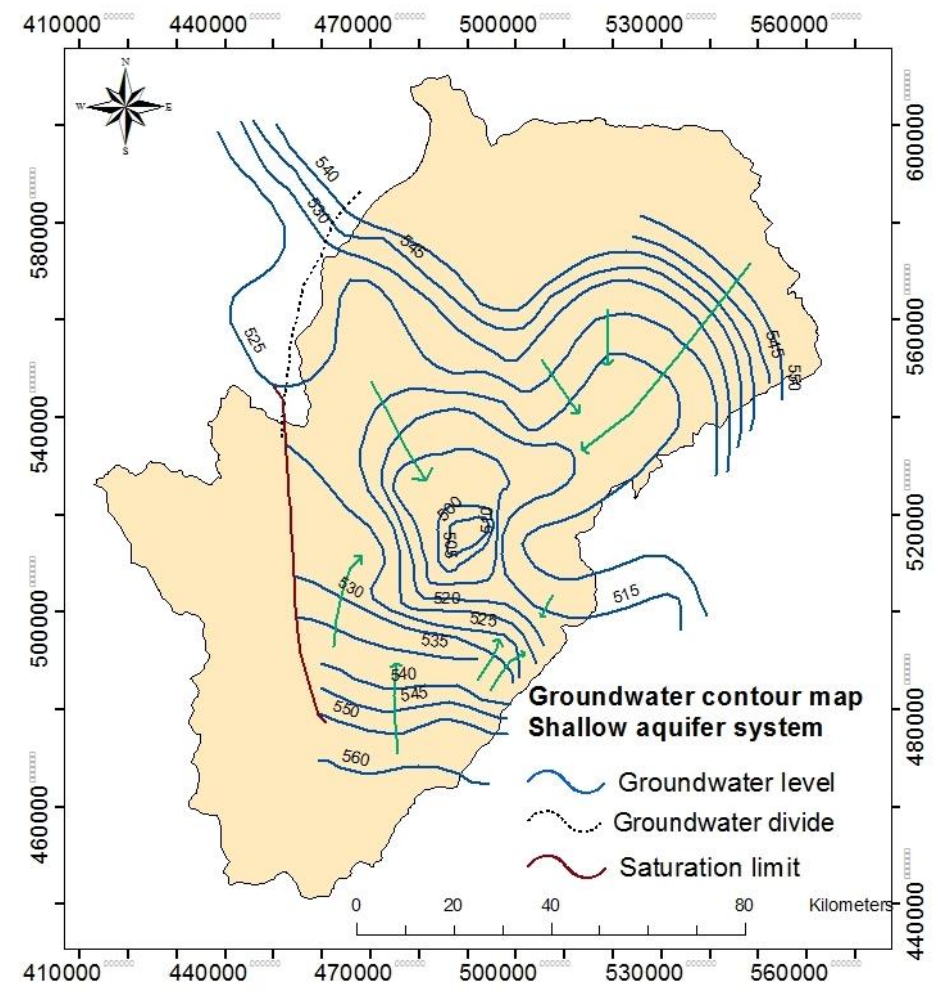

Fig. 2.6a: Groundwater flow pattern of the Upper Aquifer System, arranged after (Hobler et al., 2001)

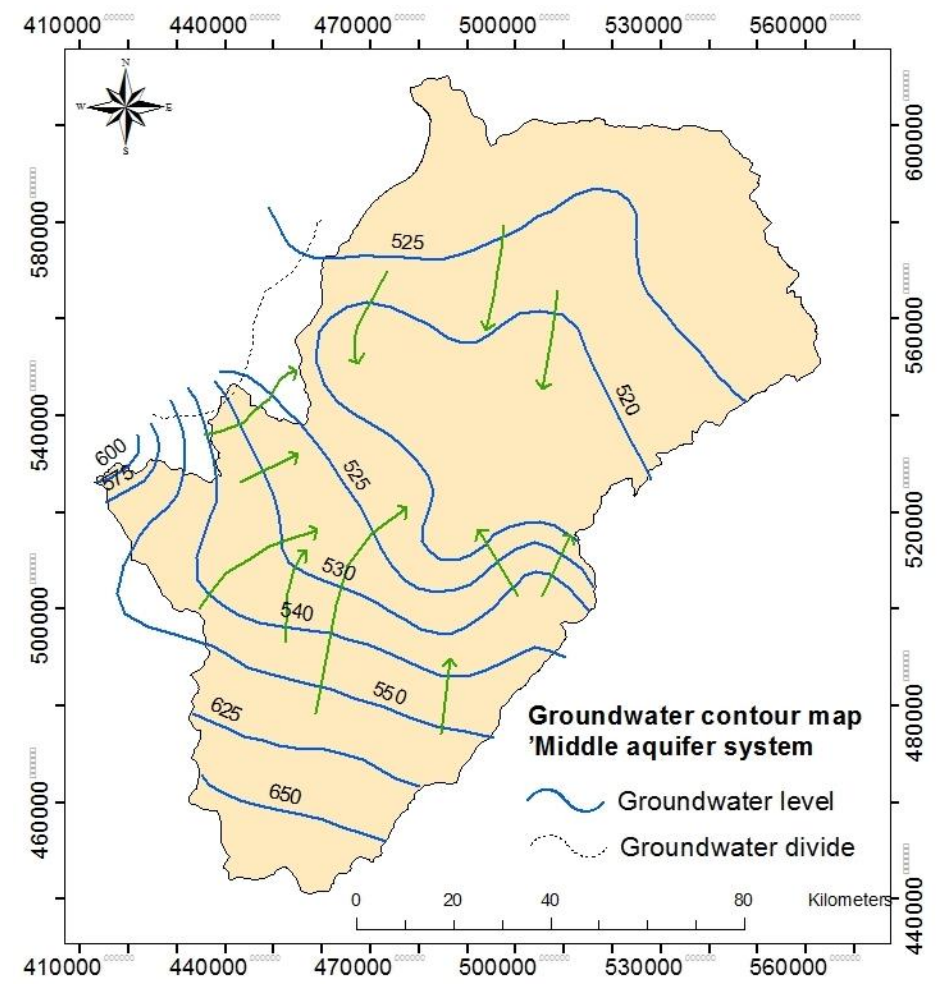

Fig. 2.6b: Groundwater flow pattern of the Middle Aquifer System, arranged after (Hobler et al., 2001) 


\subsubsection{Hydraulic properties}

The estimation of aquifer hydraulic parameters in the basin was done through the analysis of a number of pumping tests carried out in different wells in both the shallow and the middle aquifers. The main pumping tests carried out in the shallow aquifer were in the AWSA-wellfiled shortly after their construction, and the wells haven't been tested again ever since. Many other pumping test data carried out elsewhere in the basin are merely drawdown-discharge values without indication of time duration, which can't be used for the determination of aquifer parameters (Arabtech, 1994). Table 2.3 shows the coordination of the tested wells and the values of transmissivity and hydraulic conductivity estimated from the analysis of pumping tests in the Shallow Aquifer System (Arabtech, 1994). Fig. 2.7 shows the location of wells and the respective values of $\mathrm{K} \mathrm{m} /$ day. The drawdown was measured in the wells themselves, therefore no reliable estimation of storativity could be obtained. The large variability in hydraulic conductivity values of the Basalt aquifer, ranging from 0.3 to $120 \mathrm{~m} /$ day, indicate the heterogeneity of this aquifer and the existence of preferential flow. The area of AWSA well-field is attributed by a high K. Very little information was obtained from the B4/5 aquifer.

A number of wells have been tested in the middle aquifer. Table 2.4 shows the coordination of the tested wells along with $\mathrm{K}$ and $\mathrm{T}$ values estimated from the analysis of the pumping tests results (Arabtech, 1994).

Table 2.3: Results of pumping tests for the Shallow Aquifer System (Arabtech, 1994).

\begin{tabular}{|l|r|r|r|r|r|}
\hline Well & Palestine-N & Palestine-E & T $\mathbf{~ m}^{2} /$ day & Thickness $\mathbf{~ m}$ & K m/day \\
\hline KM 133 & 174700.00 & 321000.00 & 900.00 & 312.00 & 2.88 \\
\hline KM136 & 173870.00 & 323920.00 & 185.00 & 290.00 & 0.64 \\
\hline AWSA 3 & 149842.00 & 322157.00 & 12685.00 & 147.00 & 86.29 \\
\hline AWSA 2 & 150334.00 & 322143.00 & 6930.00 & 175.00 & 39.60 \\
\hline AWSA 7 & 149360.00 & 323259.00 & 20467.00 & 171.00 & 119.69 \\
\hline AWSA 13 & 148359.00 & 321195.00 & 5558.00 & 141.00 & 39.42 \\
\hline AWSA 12 & 147792.00 & 321723.00 & 15000.00 & 124.00 & 120.97 \\
\hline AWSA 9 & 150188.00 & 323217.00 & 2000.00 & 180.00 & 11.11 \\
\hline S-GWE 7 & 141030.00 & 330359.00 & 200.00 & 255.00 & 0.78 \\
\hline AWSA 4 & 150959.00 & 321861.00 & 110.00 & 169.00 & 0.65 \\
\hline AWSA 5 & 151204.00 & 321232.00 & 56.00 & 174.00 & 0.32 \\
\hline
\end{tabular}


Table 2.4: Results of pumping tests for the Middle Aquifer System (Arabtech, 1994).

\begin{tabular}{|l|r|r|l|r|r|}
\hline well & Palestine-E & Palestine-N & T $\mathbf{~ m}^{2} /$ day & Thickness m & K m/day \\
\hline NDW-2 & 295900.00 & 146300.00 & 935 & 326.00 & 2.87 \\
\hline NDW-3 & 299950.00 & 170675.00 & 7484 & 315.00 & 23.76 \\
\hline NDW-4 & 329375.00 & 173025.00 & 26 & 340.00 & 0.08 \\
\hline NDW-5 & 332650.00 & 156000.00 & 231 & 158.00 & 1.46 \\
\hline NDW-6 & 310200.00 & 149100.00 & 4348 & 379.00 & 11.47 \\
\hline NDW-8 & 270050.00 & 131875.00 & 121 & 421.00 & 0.29 \\
\hline NDW-9 & 293550.00 & 119960.00 & 289 & 660.00 & 0.44 \\
\hline NDW-10 & 284890.00 & 100765.00 & 800 & 520.00 & 1.53 \\
\hline NDW-11 & 299595.00 & 82480.00 & 322 & 315.00 & 1.02 \\
\hline NDW-12 & 279630.00 & 85590.00 & 370 & 242.00 & 1.53 \\
\hline NDW-MQ & 259500.00 & 135250.00 & 56 & 360.00 & 0.16 \\
\hline
\end{tabular}

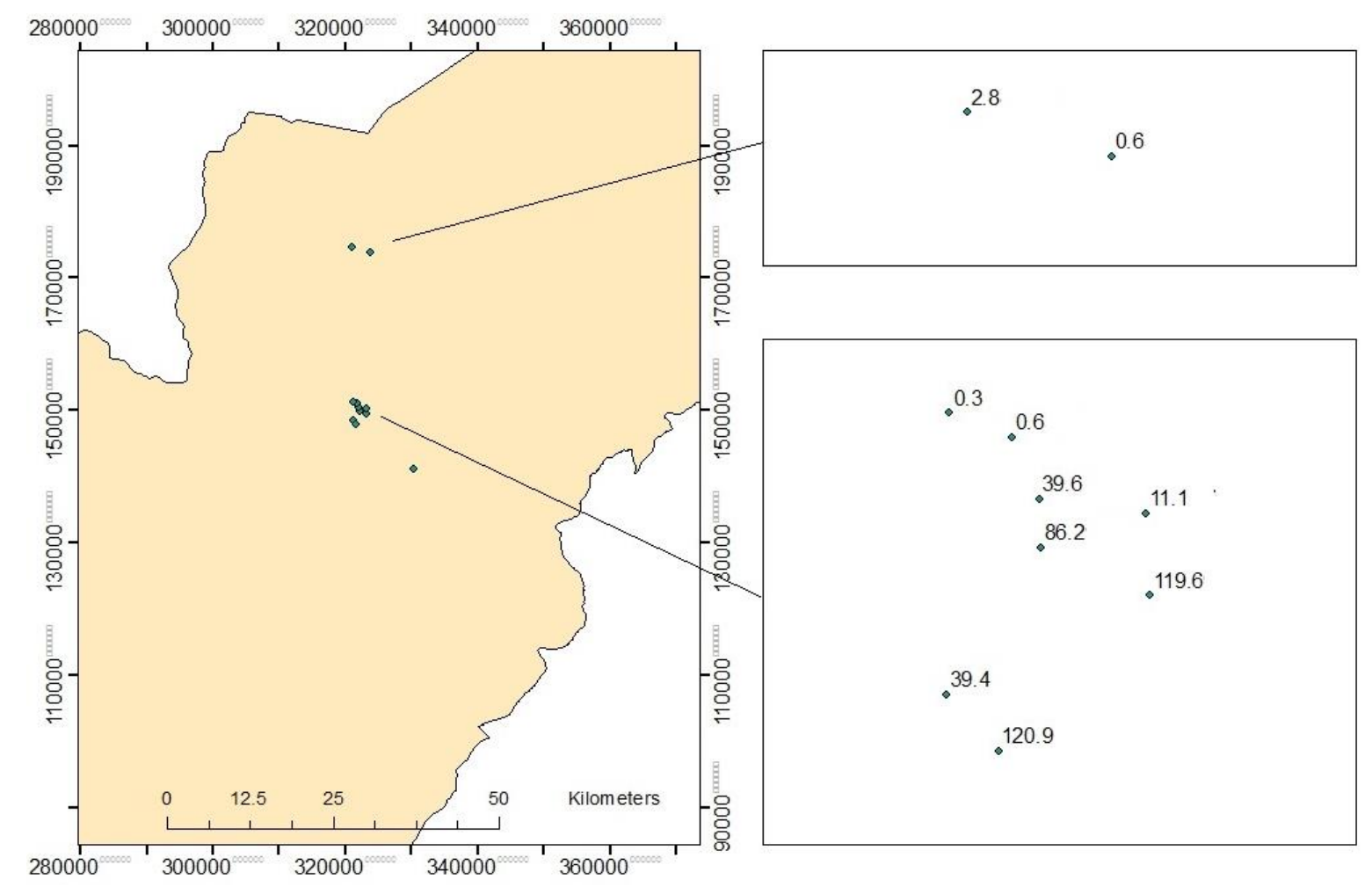

Fig. 2.7: K values $\mathrm{m} /$ day derived from pumping tests for the Shallow Aquifer System (Arabtech, 1994). 


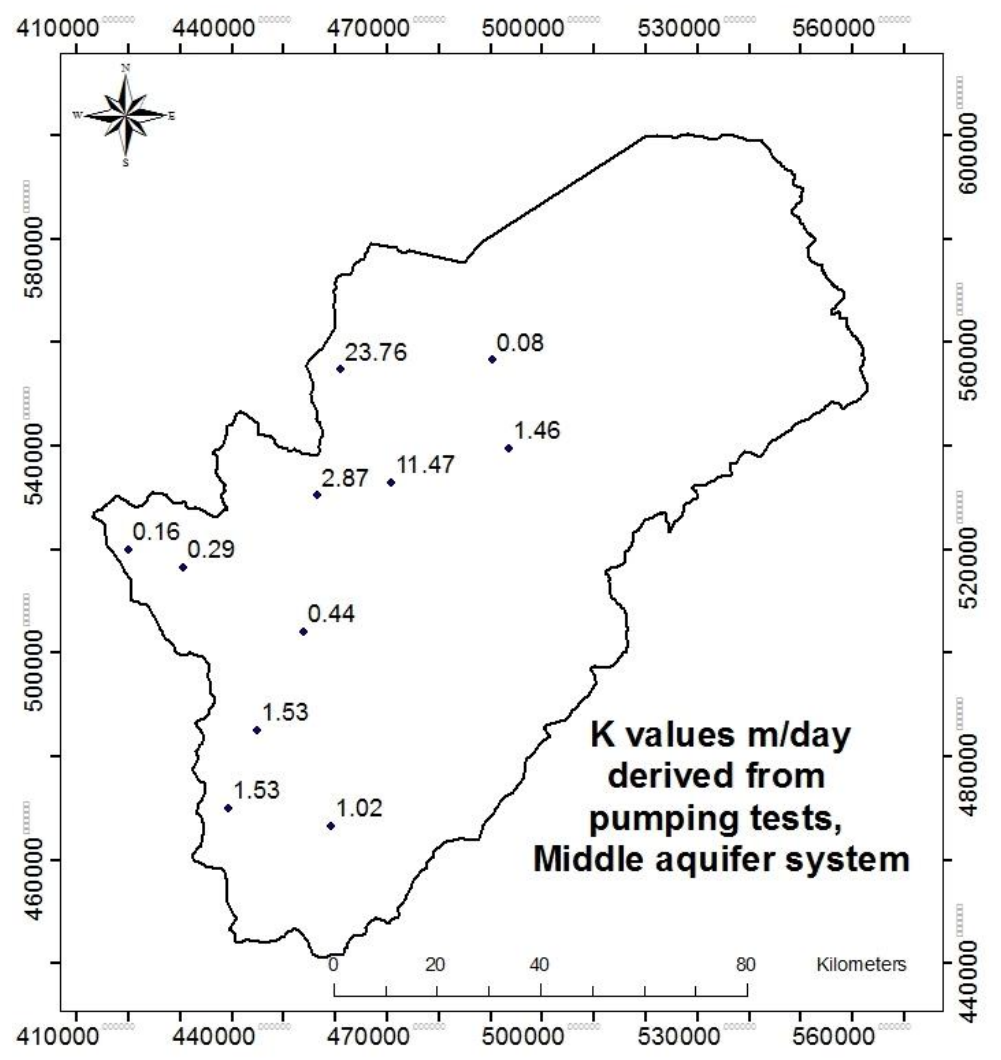

Fig. 2.8: K values $\mathbf{m} /$ day derived from pumping tests for the Middle Aquifer System (Arabtech, 1994)

\subsubsection{Springs}

There used to be two main groups of springs in Azraq located north of Azraq depression which are:

- Shishan Group: It consists of two main springs, Qaisiya and Souda, both springs discharge into separate pools where overflow drains through separate channels into the marshy area in the east.

- Drouz Group: which consists of two springs, Aura and Mustafhema springs. Both springs discharge into a swamp to the south (Ayed, 1986).

In 1965 water started to be pumped from these springs to Irbid and Mafraq cities with average rate of $240 \mathrm{~m}^{3} / \mathrm{h}$. from 1980 to 1982 the Water and Sewerage Authority started pumping water from the pools to Amman city at a rate of $900 \mathrm{~m}^{3} / \mathrm{h}$. In 1982 Azraq-well field was put in operation to pump water to Amman with a rate of $900 \mathrm{~m}^{3} / \mathrm{h}$, however, water pumping from the springs continued to supplement Irbid city area (Ayed, 1986). 
Water abstraction from AWSA-wellfiled and from other private wells increased further leading to the cessation of springs discharge in 1990. Fig. 2.9 shows monthly values of springs discharge. No continuous measurements of springs discharge are available before 1980 .

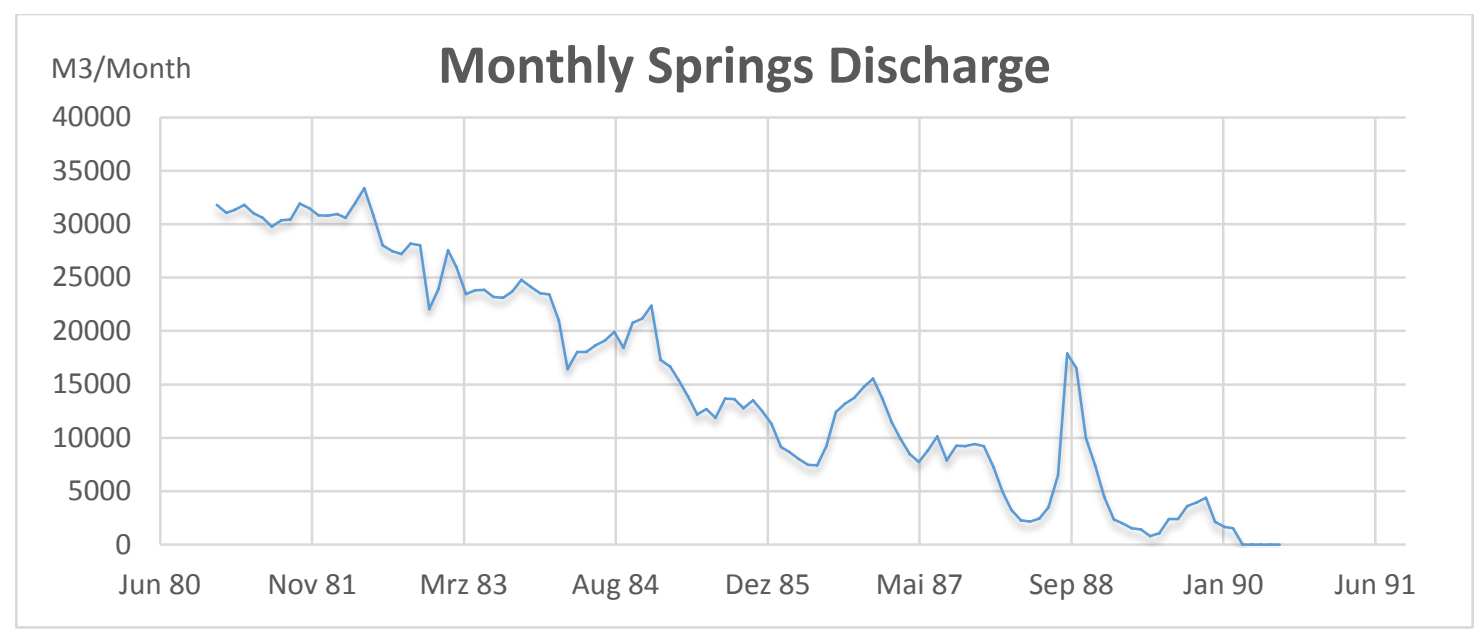

Fig. 2.9: Monthly springs discharge in Azraq basin for the period 1980-1991, (MWI, 2013)

\subsection{Climatology}

\subsubsection{Rainfall}

The source of rainfall in Azraq is mainly the cyclones which bring cold air masses from Europe causing rainfall storms of short duration and high intensity with irregular distribution (Al-Kharabsheh, 2000). A rainfall contour map showing the areal distribution of precipitation in the basin created based on long-term rainfall average calculated at rainfall stations is shown in Fig. 2.10.

The Figure shows that the amount of rainfall decreases from north to south and from west to east. The amount of rainfall exceeds $150 \mathrm{~mm} /$ year in the north of the Jordanian part and exceeds $500 \mathrm{~mm} /$ year in the Syrian part, while the southern and eastern areas receive less than $50 \mathrm{~mm}$.

The analysis of historical precipitation data at two rainfall stations F0004 and F0009 shows that in the period 1988-2012 and 1990-2012 precipitation has decreased very slightly and increased slightly in January and February for F0004 and F0009 respectively and has decreased significantly in the rest of the months 
compared with an observed baseline stretching from 1963-1987 and 1969-1989 for F0004 and F0009 respectively.

Table 2.5 shows the relative changes in rainfall amount for F0004 and F0009 stations for each month of the year. Fig. 2.11 depicts yearly precipitation at F0004 station and shows the decreasing trend of rainfall amount.

Table 2.5: Relative changes in precipitation at $\mathrm{F} 4$ and $\mathrm{F} 9$ rainfall stations.

\begin{tabular}{|c|c|c|c|c|c|c|c|c|c|c|c|c|}
\hline \multicolumn{10}{|c|}{ Relative changes in precipitation \% } \\
\hline & Jan & Feb & Mar & Apr & May & June & July & Aug & Sept & Oct & Nov & Dec \\
\hline F4 & $99 . \%$ & $88 \%$ & $42 \%$ & $29 \%$ & $48 \%$ & & & & & $53 \%$ & $46 \%$ & $72 \%$ \\
\hline F9 & $109 \%$ & $102 \%$ & $53 \%$ & $37 \%$ & $17 \%$ & & & & & $24 \%$ & $48 \%$ & $69 \%$ \\
\hline
\end{tabular}

\subsubsection{Temperature}

Mean monthly temperature ranges from around $8{ }^{\circ} \mathrm{C}$ in January which is the coldest month in the year to around $28{ }^{\circ} \mathrm{C}$ in July and August. Minimum average monthly temperature is $2.6{ }^{\circ} \mathrm{C}$ in January, while maximum average monthly temperature is $36.5^{\circ} \mathrm{C}$ in July. The analysis of historical records of temperature at F0009 station showed a slight decreasing trend of air-temperature. In the period stretching from 1988-2012 an absolute decrease in air-temperature of around 0.6 ${ }^{\circ} \mathrm{C}$ was detected based on a baseline period stretching from 1963-1987. Table 2.6 shows the absolute change in temperature in each month.

Table 2.6: Absolute historical change in temperature in each month for F0009 station.

\begin{tabular}{|l|l|l|l|l|l|l|l|l|l|l|l|}
\hline \multicolumn{10}{|c|}{ Absolute historical change in temperature ${ }^{\circ} \mathbf{C}$} \\
\hline Jan & Feb & Mar & April & May & June & July & August & Sept & Oct & Nov & Dec \\
\hline-0.83 & -0.83 & -1.00 & -0.76 & -0.34 & -0.54 & 0.01 & 0.02 & -0.72 & -0.67 & -1.04 & -1.02 \\
\hline
\end{tabular}




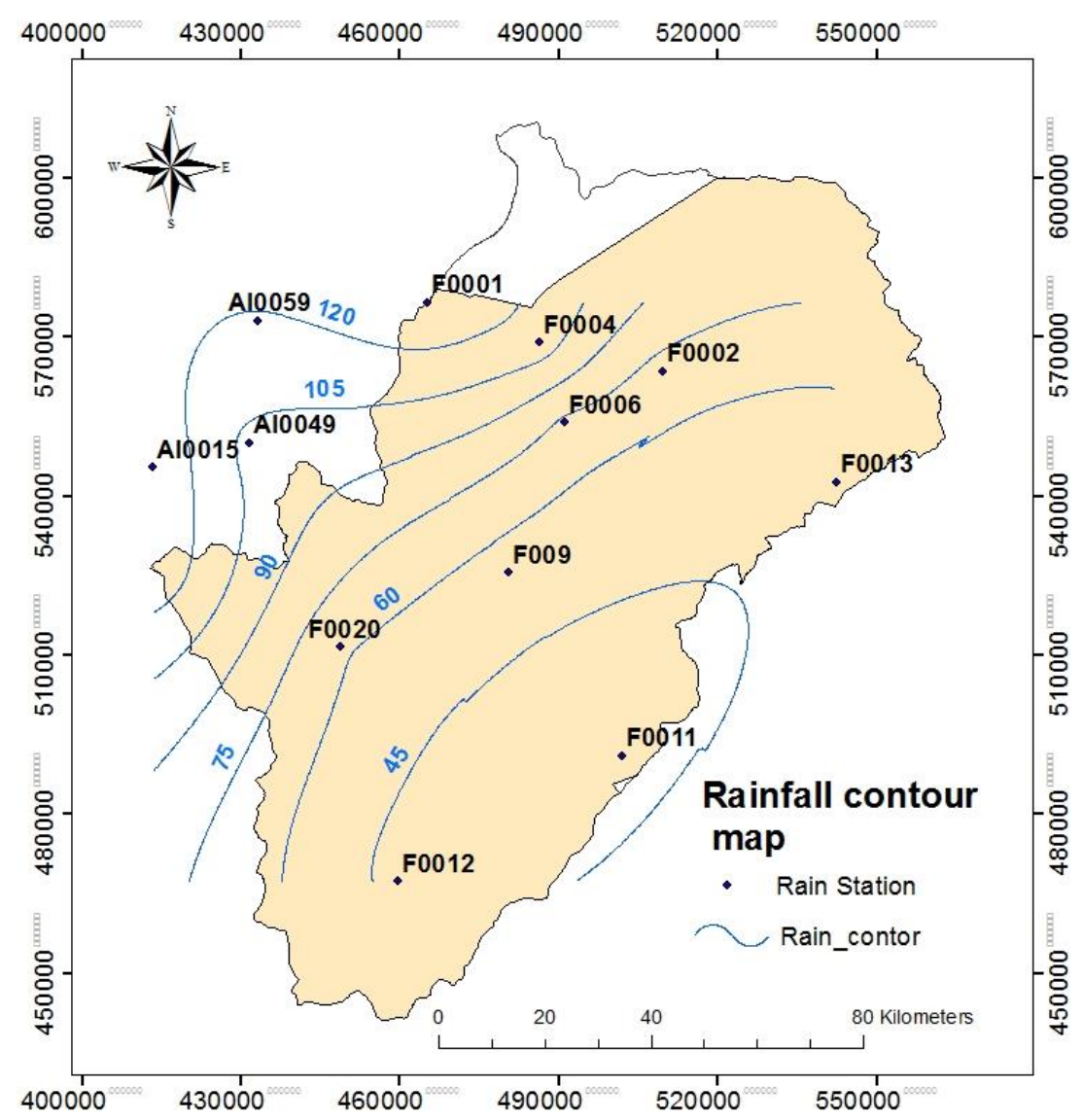

Fig. 2.10: Rainfall contour map in Azraq basin prepared based on data from (MWI, 2013)

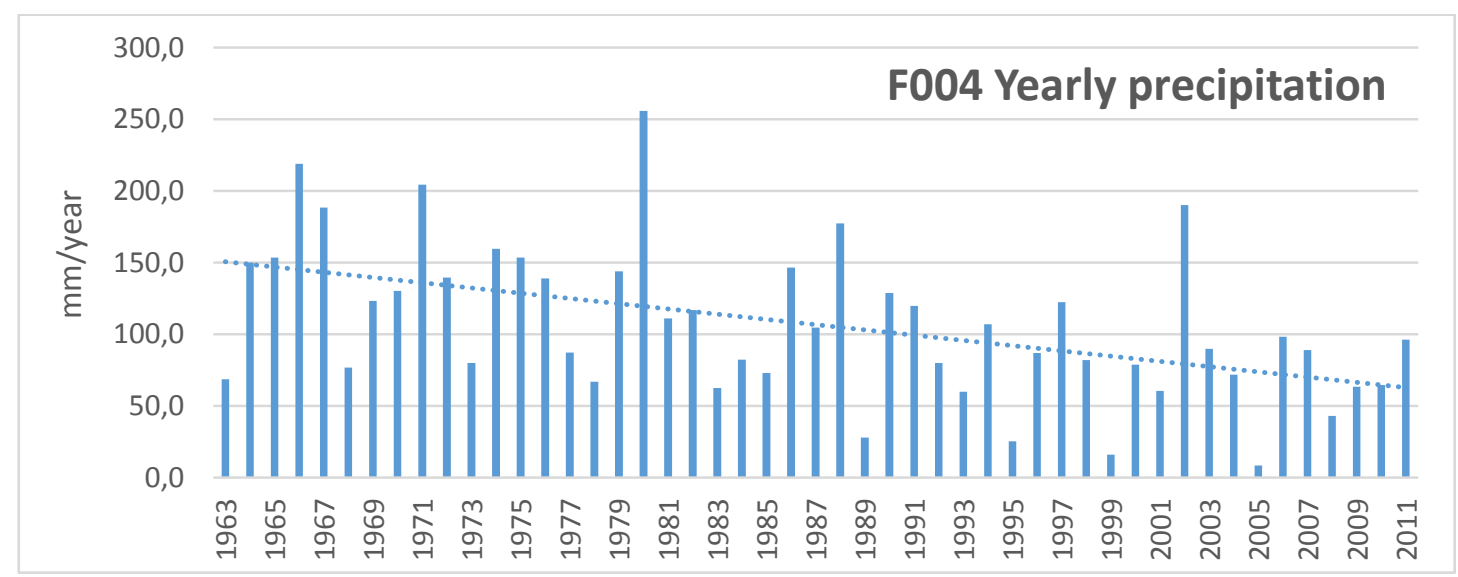

Fig. 2.11: Precipitation mm/year at F0004 rainfall station (MWI, 2016) 


\subsection{Abstraction}

Azraq is an important basin which supplies 3 major cities with potable water (Amman, Zarqa and Irbid) along with Azraq town. Pumping water from Azraq to Amman started in 1981 by Amman Water Sewerage Authority (AWSA) through many wells dug in the north of Azraq oasis (AWSA wellfield) (GEF, 1993). Rate of water pumping increased gradually to meet the increasing demand in Amman and Zarqa. In 1993 the AWSA well field became a main source of water for municipal use in Amman providing 25\% of its water needs (Darmame, 2004). Abstraction through AWSA well-field for the period 1981-2013 is shown in Fig. 2.12a.

Abstraction for agricultural purposes witnessed an enormous increase in 1980s in what is called the super green revolution where the Jordanian revenue from agriculture increased 10-fold (Mesnil and Habjoka, 2012). Since then agriculture has been developing continuously and the amount of water abstracted for irrigation purposes has been increasing due to the fact that groundwater is highly subsidized (free for the first 100,000 CM per well).

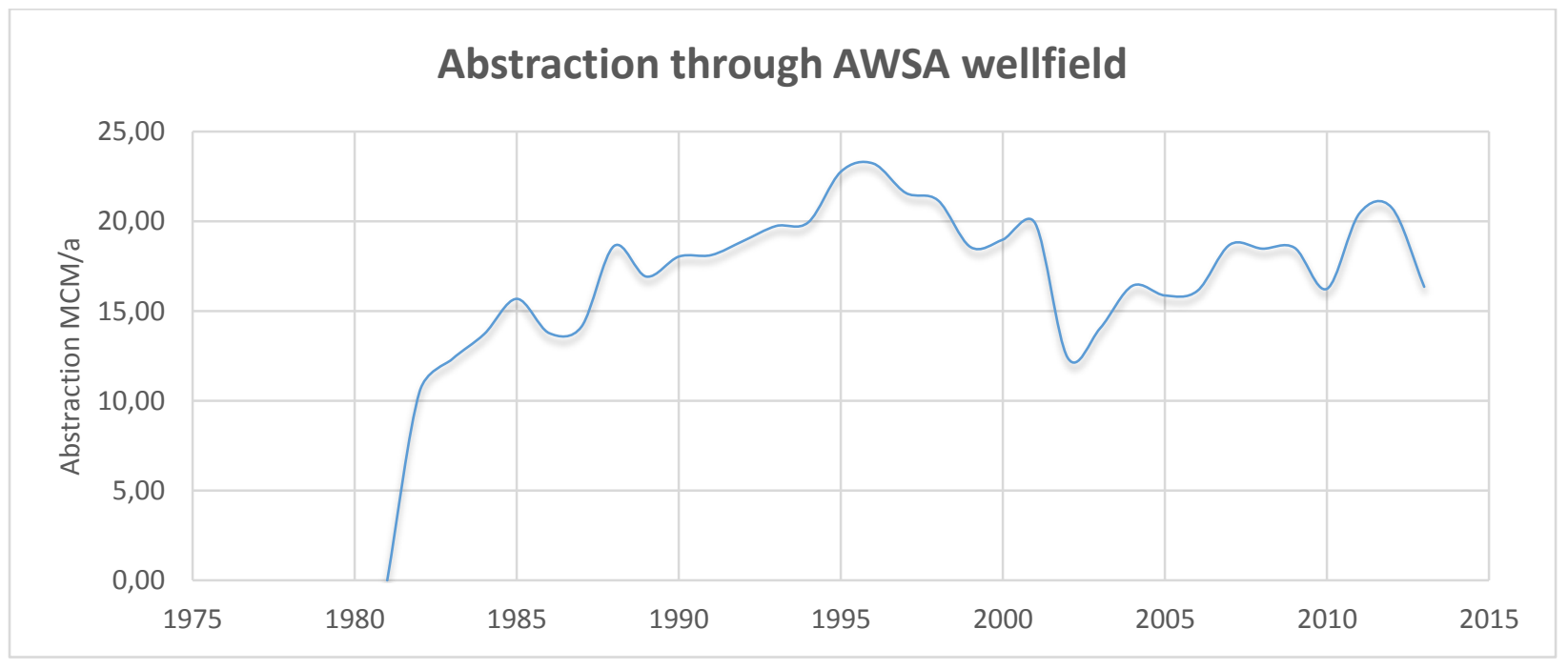

Fig. 2.12a: Abstraction rate through AWSA governmental wells from Azraq basin (MWI, 2013)

Fig. $2.12 \mathrm{~b}$ shows abstraction rate through private wells in the farming area in the center of the basin. The figure shows that water abstraction has decreased in the last years. However, according to (Water Authority of Jordan, WAJ regional office, 
2010) the number of illegal wells in the last years has greatly increased (Mesnil and Habjoka, 2012). This indicates that this decrease in abstraction is merely a shift from licensed to illegal abstraction.

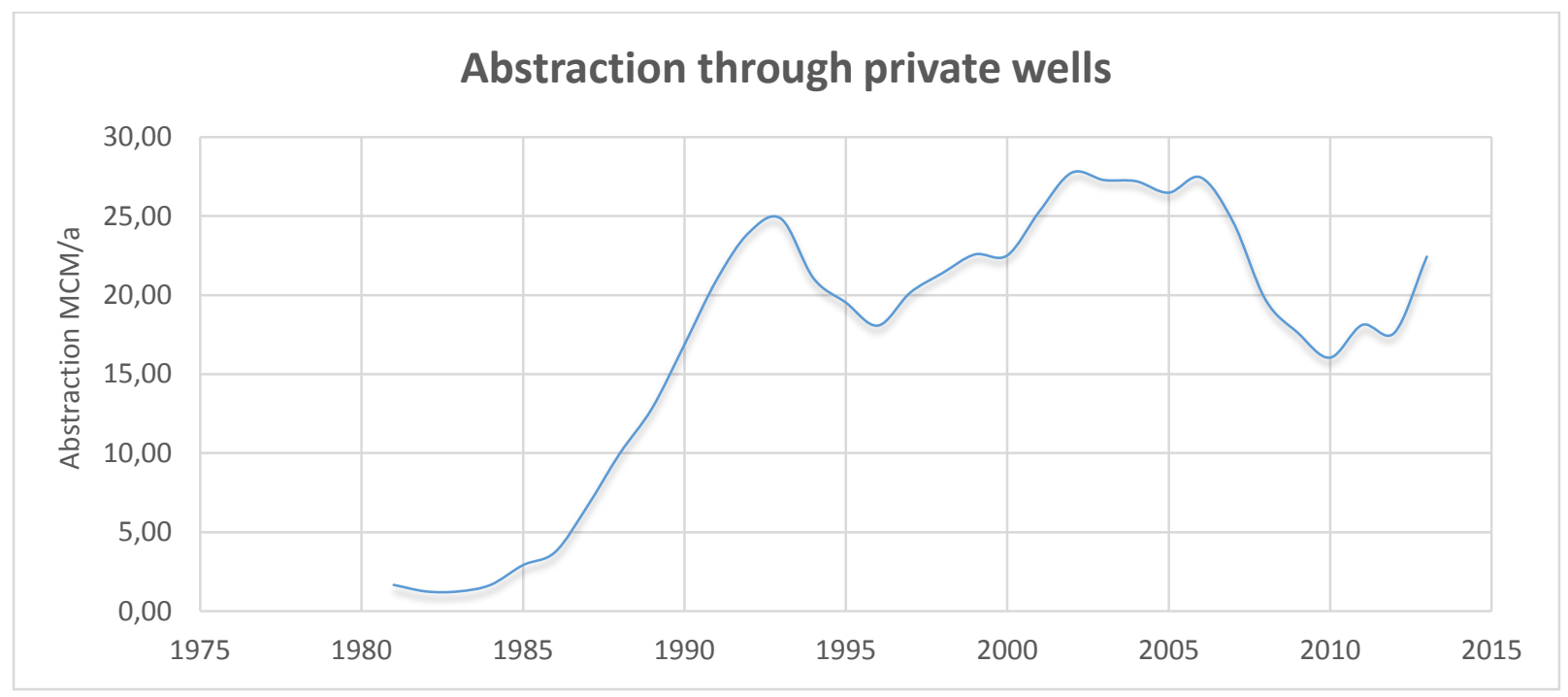

Fig. 2.12b: Abstraction rate through private wells from Azraq basin (MWI, 2013) 


\section{Managed Aquifer Recharge (MAR)}

\subsection{MAR Definition}

The process of conducting water to the aquifer system with the intention of increasing the amount of groundwater is called Managed Aquifer Recharge (MAR). The term (MAR) was introduced by Bouwer (2002) to replace the term artificial groundwater recharge which refers to groundwater recharge caused by human intervention whether it was intended or not. MAR refers to groundwater recharge that was intended in the first place. Based on Bouwer (2002), there are three main principles of MAR which are: surface infiltration, point infiltration and vadose zone infiltration.

- Surface infiltration comprises those MAR structures where water moves downwards from the surface to the aquifer system through the soil profile and rock fractures. Water should be impounded either by natural or constructed barriers. Surface infiltration provides good treatment for water when passing through the soil and underground paths.

- Point infiltration describes conducting the water into the aquifer through a specific point (injection well). This method is useful when sufficient land area is not available, when infiltration rate of the surface is low, or when groundwater aquifer is deep or confined. However, restrictions on the quality of the water recharged should be set.

- Vadose zone infiltration is a combination of the two previous principles (surface and point infiltration). It is used to induce the infiltration when the soil cover is not permeable enough by installing gravel or sand trenches penetrating into the underground.

\subsection{MAR schemes}

Numerous groundwater schemes exist internationally with different levels of engineering knowledge for implementation and maintenance. Gale (2005) grouped the methodologies applied into different categories, as shown in Table 3.1. 
Table 3.1: MAR schemes (Gale, 2005).

\begin{tabular}{|c|c|}
\hline Spreading Methods & $\begin{array}{l}\text { - Infiltration Ponds and Basins } \\
\text { - Soil Aquifer Treatment } \\
\text { - Controlled Flooding }\end{array}$ \\
\hline In-channel Modification & $\begin{array}{l}\text { - Percolation Ponds Behind Check dams } \\
\text { - Sand Storage Dams. } \\
\text { - Subsurface Dams. } \\
\text { - Leaky Dams and Recharge Release. }\end{array}$ \\
\hline $\begin{array}{l}\text { Well, Shaft and Borehole } \\
\text { recharge }\end{array}$ & $\begin{array}{l}\text { - Open Wells and Shafts } \\
\text { - Drilled Wells and Boreholes }\end{array}$ \\
\hline Induced Bank Infiltration & $\begin{array}{l}\text { - Bank Filtration } \\
\text { - Inter-dune Filtration. }\end{array}$ \\
\hline
\end{tabular}

\subsubsection{Spreading Methods}

These methods are adopted in areas where the unconfined aquifer is at a low depth. The recharge occurs when water infiltrates through permeable materials into the underground. Careful management of these schemes is of great importance when the load of suspended solids in the water resource (storm water or discharged reclaimed wastewater) is high. These sediments should be trapped before they get to the scheme in order to avoid any clogging resulting in low infiltration rate and therefore high evaporation.

- Infiltration Ponds and Basins: The water is impounded either in a basin excavated in the ground or in an area surrounded by natural bank to infiltrate into the soil (Fig. 3.1a). The amount of recharge obtained depends on the land area available for the infiltration as well as on the infiltration rate. Clogging is the main problem associated with these schemes especially when the basin material is fine.

- Soil Aquifer Treatment (SAT): Reclaimed wastewater from sewage treatment plants are applied in infiltration ponds to be recharged through the soil profile into the aquifer (Fig. 3.1b). Beside smoothing out the supply demand variability through water storage, this process has several other advantages including water quality improvement due to passage through the soil and aquifer, favorable economics, and better public acceptance of water reuse. 
- Controlled Flooding: Diverting water from rivers by channels and evenly spread them over a large area to be infiltrated into the aquifer.

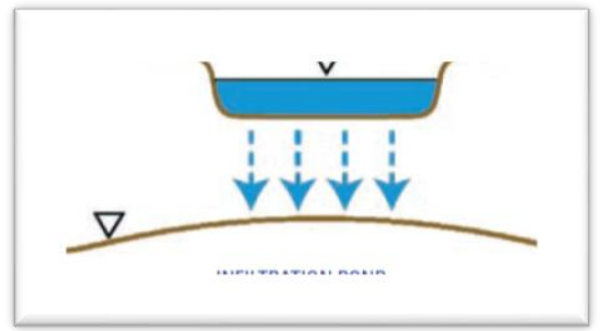

(a)

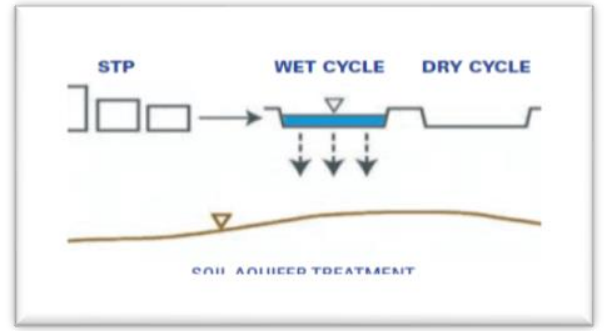

(b)

Fig. 3.1: Spreading Methods

a: Infiltration Pond, b: Soil Aquifer Treatment (Gale, 2005)

\subsubsection{In-channel Modifications}

- Percolation Ponds Behind Checkdams: A checkdam is constructed on a streambed from materials available in situ. A concrete spillway is constructed to avoid any erosion or destruction of the dam. Building a series of these dams along a drainage line helps reduce erosion and sediments transport (Fig. 3.2a).

- Sand Storage Dams are constructed in undulating terrain under arid-climatic conditions where flash floods are expected. A dam wall is constructed across the width of the river bed to slow down the flash flood leading coarser materials to settle and accumulate behind the dam wall where fine materials are carried away with the over flow. After successive floods, an artificial aquifer is built allowing water to infiltrate (Fig. 3.2b).

- Leaky Dams and Recharge Releases: Flashy water that contains a large amount of suspended solids ends up usually in the sea or wadis before it can infiltrate to the aquifer system. A dam is constructed to mitigate water velocity and trapping the sediments. The water is then released from a pipe running through the dam into the downstream reach of the river where it can infiltrate easily (Fig. 3.2c).

- Subsurface Dams or underground dams are used to detain water in alluvial aquifers (Fig. 3.2d). 


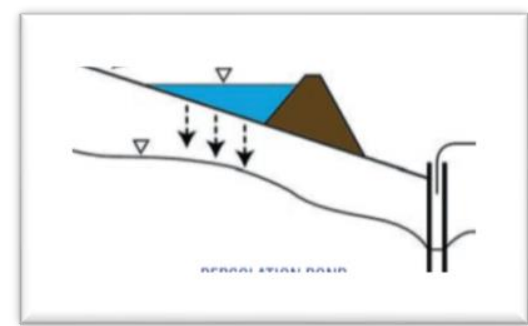

(a)

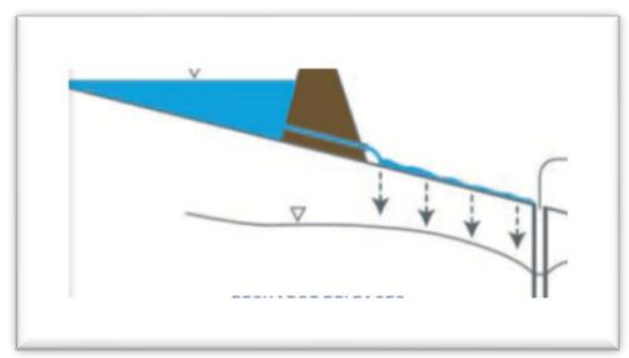

(c)

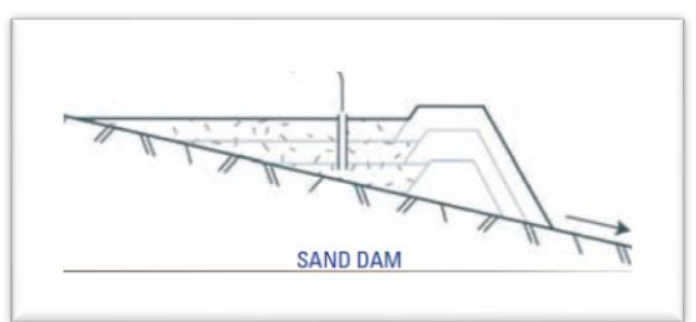

(b)

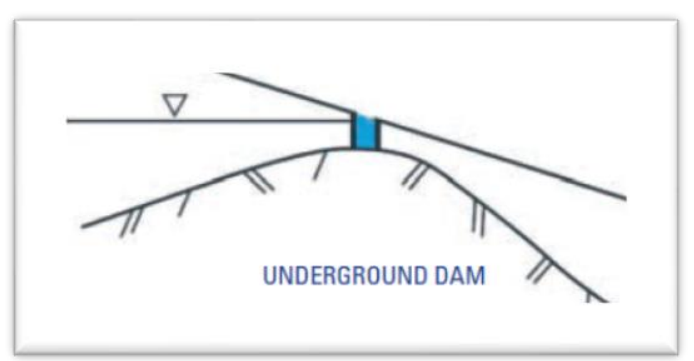

(d)

Fig. 3.2: In-channel Modifications

a: Percolation Pond, b: Sand Dam, c: Recharge Releases, d: Underground Dam (Gale, 2005).

\subsubsection{Well, Shaft and Borehole Recharge}

- Open Wells and Shafts: When spreading methods are not applicable due to low infiltration rate, open wells are adopted to recharge shallow aquifer. Primary sedimentation for the recharge water is needed. As water is introduced into the aquifer system directly without passing through the soil profile, restrictions on the quality of the recharge water are set.

- Drilled wells and boreholes are used where thick and low permeability strata overlie target aquifers. Restrictions on the quality of water recharge should be set (Fig. 3.3). 

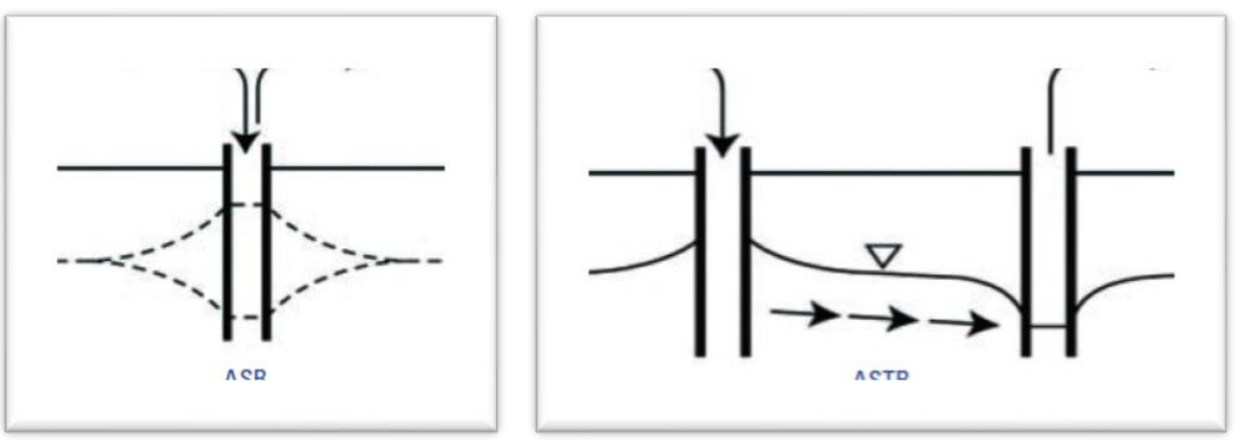

Fig. 3.3: Drilled Well (Gale, 2005).

\subsubsection{Induced Bank Infiltration}

- Bank Filtration: Extraction of groundwater from a well near or under river or lake to induce infiltration from the surface water body and thus, improving the quality of water recovered (Fig. 3.4a).

- Inter-dune Filtration: Applied in coastal areas where water from rivers is stored in valleys between coastal dunes to infiltrate into the underlying sediments forming a recharge mound. In addition to providing a source of water, the application of this scheme helps prevent saltwater intrusion into the groundwater system (Fig. 3.4b).

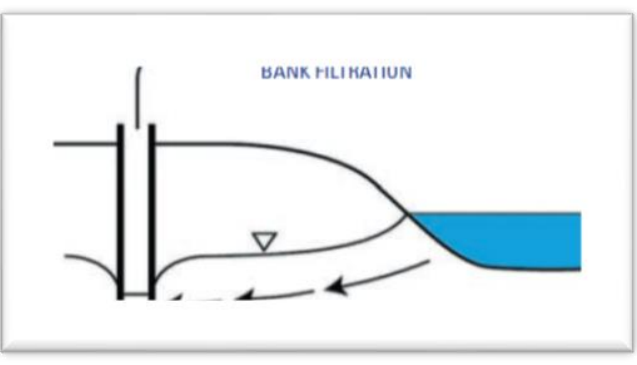

(a)

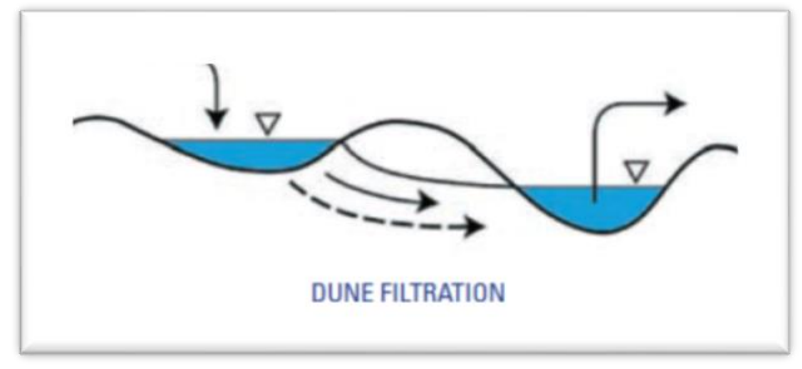

(b)

Fig. 3.4: Induced Bank Infiltration

a: Bank Infiltration, b: Dune Filtration (Gale,2005). 


\subsection{Clogging issue}

Clogging is a predominant problem associated with many MAR schemes especially those of surface infiltration. Clogging is caused by fine particles or by the growth of algae resulting in lowering the efficiency of these schemes. Based on Gale (2005), many procedures can be adopted here to counteract this problem:

- Construction of siltation ponds that trap fine particles by mechanical settling before they reach to the structure. Settling efficiency can be enhanced by adding some flocculating chemicals.

- Chlorination of the recharge water to inhibit algae growth and microbial activity.

In the case of infiltration basins:

- Lining the bottom and sides of the basin with a medium sand layer of $0.5 \mathrm{~m}$ thickness.

- Adopting a rotational system of water spreading, drying and subsequent scraping. Drying helps get rid of the algae that might grow in the basin and scraping helps maintain a suitable infiltration rate.

\subsection{Parameters and restrictions of MAR potential map}

Suitable sites for MAR are delineated based on an investigation of surface and subsurface characteristics. The following parameters and factors are considered during the process of MAR sites section:

\subsubsection{Infiltration rate}

Infiltration rate of surface water into the soil is the first influencing parameter that should be taken into consideration when planning MAR sites. Slope and soil type are important factors that determine the infiltration rate of water in a given area.

Infiltration rate is strongly related to prevailing soil texture. Ghayoumian, et al. (2007) calculated the infiltration values in southern Iran based on texturepermeability relationships established by the Food and Agriculture Organization (FAO), and then used these values to determine areas most suitable for artificial groundwater recharge. 


\subsubsection{Geological conditions}

The geological conditions in the unsaturated zone are of great importance for MAR sites planning especially when schemes using spreading techniques are adopted. The vertical permeability of the vadose zone determines the rate of water percolation into the aquifer (Gale, 2005). For example, when the aquifer is covered by superficial alluvial, that have a high permeability, water is allowed to percolate to the aquifer at a higher rate without being stored in the soil for long time and getting lost for evaporation. Additionally, faults can enhance MAR potential by facilitating the vertical movement of water into the aquifer.

\subsubsection{Hydrogeological conditions}

Once the recharged water reaches the water table of an unconfined aquifer, the amount of water that can be stored depends on the hydraulic conductivity $(\mathrm{K})$ and the thickness of the aquifer. The underground formation must have sufficient thickness and $\mathrm{K}$ in order to be able to receive recharged water at an acceptable rate.

However, K should not exceed a certain value because this can result in rapid dispersal of the recharged water leading to reduce the quantity of water that can be recovered, or can result in minimizing the time of storage when water is discharged in one of the springs located close the MAR site (Gale, 2005).

Groundwater should be at sufficient depth to prevent the interference between the building groundwater mound and the infiltration process (Anbazhagan, et al., 2005). In addition, high water table result in rapid transfer to discharge points in streams and rivers (Gale, 2005).

\subsubsection{Water quality}

In order to express water quality in an easy way, different Water Quality Indices (WQI) have been developed to summarize water quality data into a simple easily expressible term. The most important parameters used to calculate WQIs are PH, Total Dissolved Solids (TDS), total hardness, calcium, total alkalinity, Dissolved Oxygen (DO) and Electrical Conductivity (EC) (Kumar and Dua, 2009).

Based on the purpose of the recharge, TDS of the receiving aquifer is identified. If recharged water is recovered by urban settlements for drinking purposes, TDS in the receiving aquifer should not exceed a certain level $(1000 \mathrm{mg} / \mathrm{l})$. 
When MAR is constructed to elevate the groundwater level to avoid salt water intrusion or prevent the occurrence of sink holes, water quality is of minor importance. Table 3.2 shows ranges of TDS of water for different purposes of water supply as recommended by MWI and GTZ (2004).

Table 3.2: Acceptable ranges of TDS values for different purposes (MWI and GTZ, 2004)

\begin{tabular}{|l|l|}
\hline Purpose & TDS [mg/l] \\
\hline $\begin{array}{l}\text { Good for drinking \& generally no restriction in } \\
\text { irrigation }\end{array}$ & $>1000$ \\
\hline Slight to moderate restriction on irrigation use & $1000-2000$ \\
\hline $\begin{array}{l}\text { Severe restriction on irrigation use, only for } \\
\text { special crops }\end{array}$ & $2000-2800$ \\
\hline Usable only after desalination & $2800-5000$ \\
\hline
\end{tabular}

\subsection{Existing MAR projects in Jordan}

The Wadi Madoneh multi-stage reservoir is located in the Zarqa basin, $20 \mathrm{~km}$ northeast of Amman and $9 \mathrm{~km}$ south of the city Zarqa with a total catchment area of $57 \mathrm{~km}^{2}$ to recharge the unconfined Upper Limestone Aquifer (A7) with a total potential recharge volume of 0.5 MCM (Abu-Taleb, 1999 and 2003).

As proposed by Abu-taleb (2003), on 4 tributary channels of Wadi Madoneh, seven dikes ( $2.5 \mathrm{~m}$ in height) and one dam ( $5 \mathrm{~m}$ in height) have been constructed. Each dike is designed to retain a small amount of water and discharge the excess runoff to downstream dikes.

Wala Dam Situated $45 \mathrm{~km}$ south of Amman in the Mujib surface water basin as part of the Dead Sea Groundwater Basin with a catchment area of around $2000 \mathrm{~km}^{2}$ and groundwater depth of up to $35 \mathrm{~m}$ (Pavelic, 2005). The dam recharges the Upper Limestone Aquifer (A7/B2). The additional water is used for irrigation and drinking supply. The dam is provided with 9 injection wells to enhance the infiltration (Rapp, 2008). 


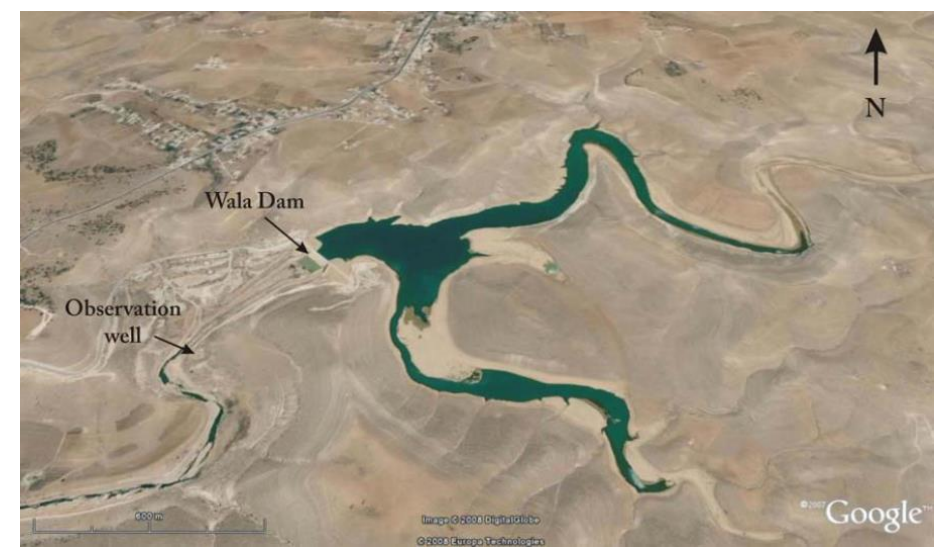

Fig. 3.5: Wala Dam (Google Earth)

Siwaqa Dam is situated $70 \mathrm{~km}$ south of Amman in the Mujib basin to replenish the Upper Cretaceous Limestone Aquifer (A7/B2) with a capacity of $2.5 \mathrm{MCM}$ (Pavelic, 2005).

Rajil Damis situated in the extremely arid Azraq basin of eastern Jordan, around $30 \mathrm{~km}$ east of the town Azraq with a capacity of 3.5.MCM. Water impounded infiltrates in the basalts overlying the Upper Limestone Aquifer (B4/B5). The purpose of this dam was to restore Wadi Rajil oasis which had fallen dry due to overabstraction for agriculture and urban usages (Pavelic, 2005).

\subsection{MAR-site-selection, the state of the art}

Managed Aquifer Recharge (MAR) is considered as an effective tool for the sustainable management of groundwater resources in arid and semi-arid areas (AlAssa'd and Abdulla, 2010; Chenini and Ben Mammou, 2010).

MAR implementation has been reported in many studies with a special emphasis on the determination of areas most suitable for artificial recharge. The application of Geographical Information System (GIS) in choosing suitable sites for MAR has been practiced by several researchers where thematic maps of factors representing surface and subsurface characteristics are prepared weighted and integrated. There is considerable variability among studies concerning the number and type of factors to be considered, and the relative importance of factors. 
Alraggad and Jasem (2010) and Mahmoud et al. (2014) assigned suitable sites for MAR implementation based on surface characteristics and aquifer confinement with no integration of hydrogeological factors.

Beside surface characteristics and other hydrological factors, Zaidi et al., (2015) and Ghayoumian et al. (2007) integrated the depth to groundwater as a detriment factor for locating MAR. Steinel (2012) and Rahman, (2012, 2013) included aquifer thickness and depth to groundwater. Taheri and Zare (2011) included the specific yield and thickness of alluvial layer. Ghayoumian et al. (2005) included aquifer thickness and transmissivity, while Bhuiyan (2015) included all hydrogeological factors.

Each thematic layer of considered criteria is multiplied by a number (weight) to consider its relative importance. Variable weights have been given to factors in many studies. Table 3.3 shows a comparison between weighting values of criteria in three MAR studies.

After assigning relative importance of every factor (criterion), the factors are classified or standardized based on their suitability for the implementation of MAR. Unsuitable ranges of each factor are determined to create a constraint map. The criteria of assigning suitable and unsuitable values for each factor is variable among studies and seem to be chosen arbitrarily. Table 3.4 shows a comparison of varying suitability ranges of depth-to-groundwater suggested by 5 studies.

Table 3.3: Weighting values of suitability criteria provided by Gaur et al. (2011), Ghayoumian et al. (2007) and Saraf \& Choudhury (1998)

\begin{tabular}{|c|c|c|c|}
\hline \multirow{2}{*}{ Criteria } & \multicolumn{3}{|c|}{ Relative importance weights } \\
\cline { 2 - 4 } & $\begin{array}{c}\text { Gaur et al. } \\
(\mathbf{2 0 1 1})\end{array}$ & $\begin{array}{c}\text { Ghayoumian et al. } \\
(\mathbf{2 0 0 7 )}\end{array}$ & $\begin{array}{c}\text { Saraf \& Choudhury } \\
\text { (1998). }\end{array}$ \\
\hline Soil Texture & 0.7 & 0.95 & 1 \\
\hline Soil Thickness & & & \\
\hline $\begin{array}{c}\text { Depth to Water } \\
\text { Table }\end{array}$ & & 0.8 & 1 \\
\hline Transmissivity & 0.7 & & 1 \\
\hline Slope & 0.8 & 0.7 & \\
\hline Land Cover & 0.9 & & \\
\hline
\end{tabular}


Table 3.4: Suitability ranges of depth to groundwater suggested by 5 studies.

\begin{tabular}{|l|l|l|l|l|}
\hline & $\begin{array}{l}\text { Zaidi et al. } \\
\mathbf{( 2 0 1 5 )}\end{array}$ & Steinel (2012) & $\begin{array}{l}\text { Ghayoumian et } \\
\text { al., (2005) }\end{array}$ & $\begin{array}{l}\text { Rahman et al., } \\
(\mathbf{2 0 1 2 , 2 0 1 3 )}\end{array}$ \\
\hline $\begin{array}{l}\text { Suitable depth to } \\
\text { groundwater (m) }\end{array}$ & $(20-140) \mathrm{m}$ & $20-200 \mathrm{~m}$ & $>10 \mathrm{~m}$ & $>10 \mathrm{~m}$ \\
\hline
\end{tabular}

The response of groundwater table underneath an infiltration basin can be an indicator of the suitability of a site for MAR. If calculated, groundwater mound's height provides the summed impacts of aquifer characteristics on the process of artificial recharge and provides information on the amount of water that could be stored. The site is deemed suitable, when the groundwater mound resulting from infiltrating a certain amount of water within a certain period doesn't rise above the ground surface. The application of such quantitative approach in assigning suitable sites for MAR has been limited in the literature. Smith and Pollock (2012) applied the analytical solution of Glover (1961) on a spatial scale across Perth Coastal Plain in Australia, to compute groundwater mounding height under different scenarios of recharge loads, and used the results to create suitability mas for MAR implementation. 


\section{Methodology of data acquisition and analysis}

\subsection{Data collection and data base}

Proposing management solutions should be based on a good understanding of the basin characteristics and a quantification of the water cycle components. Rainfall and climatological data as well as information on runoff potential should be collected and processed in order to quantify inputs and outputs in the system, and quantify subsequently the change of storage in the basin (groundwater recharge).

The construction of a hydrogeological model, and later the process of MAR site selection requires spatially distributed data on the physical property of the basin (elevation, slope, landuse, soil type). Additionally, observed data on water table fluctuation and springs discharge are needed for the calibration process.

Time series data on rainfall, climatological data, springs discharge, observed level of groundwater table were collected from the Ministry of Water and Irrigation (MWI, 2013), Jordan, along with data on the basin's physical properties like soil type and elevation of aquifer base. a GIS database has been prepared using ArcGIS 10.2-ArcMap 10.2 where thematic layers of basin properties have been prepared based on the acquired data. The Jordanian coordination System (JTM) was used as a geographic referencing system to all produced layers and maps.

\subsection{Remote sensing and GIS}

The use of remote sensing data has been essential in hydrological studies as a great tool for the acquisition of spatial data on landuse, typography, stream network and others. In the application of remote sensing techniques, Geographic Information System (GIS) is a widely used software system for storing, managing, analyzing, and visual expressing of geographic information (Apel, 2006, Yoo and Kim, 2007).

In this study a Land use map, slope map and a map of surface catchments and drainage lines in the basin have been prepared based on the analysis of Digital Elevation Model (DEM) and a satellite image. 


\subsubsection{Landuse}

A Landsat satellite image was acquired from the U.S. Geological survey (USGS) in June 2013, for the delineation of land cover in the Azraq basin. The image has a resolution cell size of $30 \mathrm{~m} \times 30 \mathrm{~m}$. It was first projected to JTM coordinate system and then it was clipped off for the study area.

In the image (Fig. 4.1) the farming areas can be easily distinguished in the north west and central of the basin, while the basalt formation can be seen covering the northern part of the basin. Another distinctive feature which can be recognized in the image is the river beds especially in the southern part of the basin.

The majority of the basin is covered with basalt rocks, chert plains and alluvial deposits (more than 96\%). Only the farms were delineated by applying supervised classification on the Landsat image.

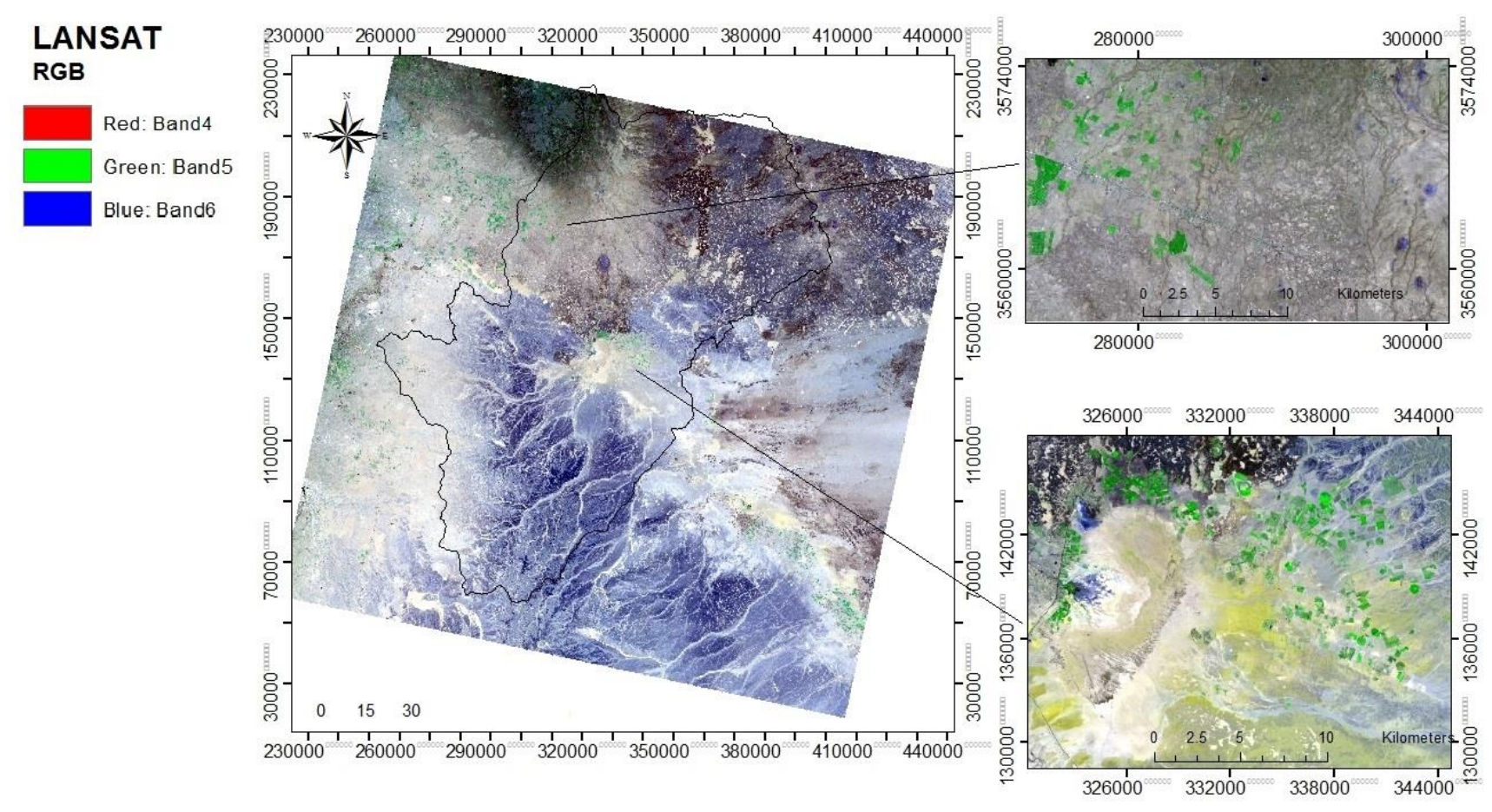

Fig. 4.1: Landsat satellite image for Azraq basin (USGS, 2013) 


\subsubsection{Digital Elevation Model}

A 30*30 DEM was downloaded from the USGS website (Fig. 4.2a). The elevations within the basin decrease from the edges towards the central area where a large flat depression known as the Qaa was developed at an elevation of $500 \mathrm{~m}$. The highest point is located in the Jebel El-Arab area in Syria, with an elevation of about $1600 \mathrm{~m}$ above mean sea level

\subsubsection{Slope map}

A map of slope in percentage of the area is prepared based on the DEM using GIS, (Fig. 4.2b). Slope is described as gently epically within the Qaa area and it increases within the hilly relief surrounding the Qaa to reach its maximum value in the north.

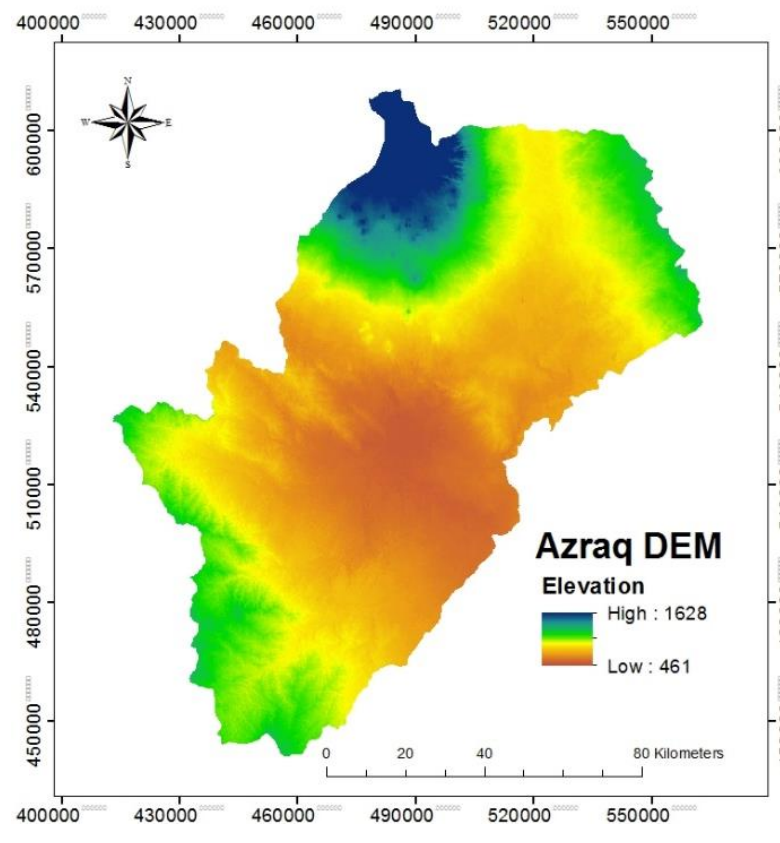

(a)

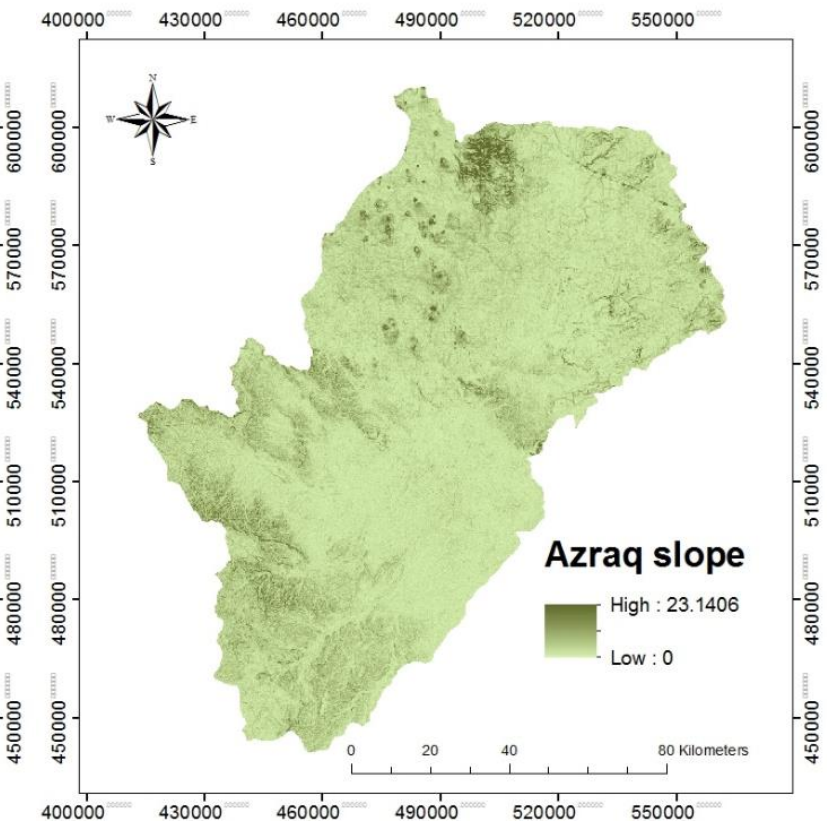

(b)

Fig. 4.2 a: USGS DEM of Azraq basin (30*30), b: Slope distribution in Azraq (degree), generated from USGS-DEM

\subsubsection{Delineation of surface catchments}

The rainfall that the basin receives drain through non-perennial streams through a number of wadis into the central area where it remains for a month or two before it 
evaporates. Nine wadis comprise the drainage system of the basin which are: Rajil, Useikhim, Mudeisisat, Unqiya, Jesha, Hassan, Er-Ratam, Ghadaf and Al-Botum, all characterized as wide shallow flow-bed with generally low slopes (MWI and GTZ. 2003).

The drainage line through the different wadis in Azraq basin was delineated based on the USGS DEM. An extension tool (ArcHydro) of GIS software is used to process the USGS DEM for defining flow direction and accumulation and delineate the drainage line in Azraq basin along with its segments, and finally delineate the watershed by identifying its outlets and merging the underlying catchments (Fig. 4.3).

\section{Drainage-line and Sub-catchment areas}

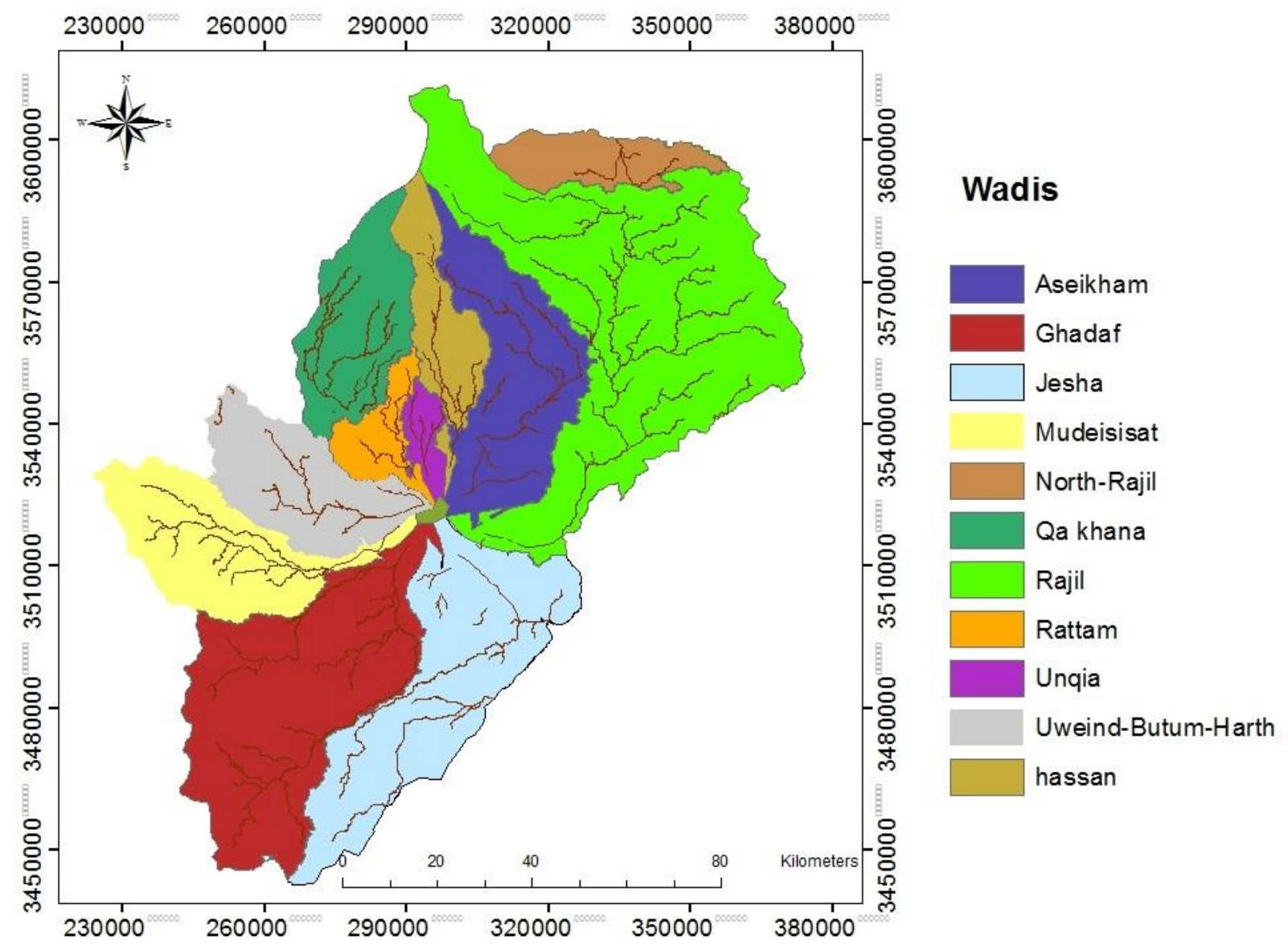

Fig. 4.3: Drainage line und subcatchments in Azraq prepared based on a USGS DEM (30*30) 


\subsection{Rainfall}

Time series data of rainfall recorded at 9 stations distributed in the basin were collected from the Ministry of Water and Irrigation, Jordan. Some stations were missing few daily measures. Missing daily data were estimated either from linear regression methods or from a combination between the Ratio and Quadrant method.

Good correlation was found between recorded rainfall at F1 and F4 stations, see Fig. 4.4a. The linear equation was used to estimate missing data in these two station. As the intensity of station in the south of the basin is low, and the difference in average annual precipitation between these stations is big, correlation method was used to estimate missing readings. Correlation between recorded rainfall at F6 and F9 stations is shown in Fig. 4.4b.

A combination between mean and Quadrant-Method is applied to estimate missing data at F6 station from records at F2, F1 and F4 using equation (4.1).

$$
\mathrm{F} 6=\frac{\left(F 1 * D_{F 1 F 6}\right)+\left(F 2 * D_{F 2 F 6}\right)+\left(F 4 * D_{F 4 F 6}\right)}{\left(D_{F 1 F 6}+D_{F 2 F 6}+D_{F 4 F 6}\right)}
$$

Where:

$D_{F 1 F 6}, D_{F 2 F 6}, D_{F 4 F 6}$ are the distance between F6 and F1, F2 and F4 respectively.

Fig. 4.4c shows good correlation between measured rainfall records at F0004 and calculated values using this equation.

For the estimation of areal precipitation in the basin, the Thiessen Polygon method was applied. Fig. 4.5 shows the Thiessen Polygons designed for the basin.

The calculation of rainfall volume was done on a wadi-basis. The partial areas of each wadi covered by Thiessen Polygon were determined first (Table 4.1), and then the volume of rainfall in the basin was calculated. Fig. 4.6 depicts yearly rainfall volume that the basin receives for the period (1970-2013). Yearly rainfall range between 290-2100 MCM with an average value of $1050 \mathrm{MCM}$. The records show a big variance and high inter-annual variability. 


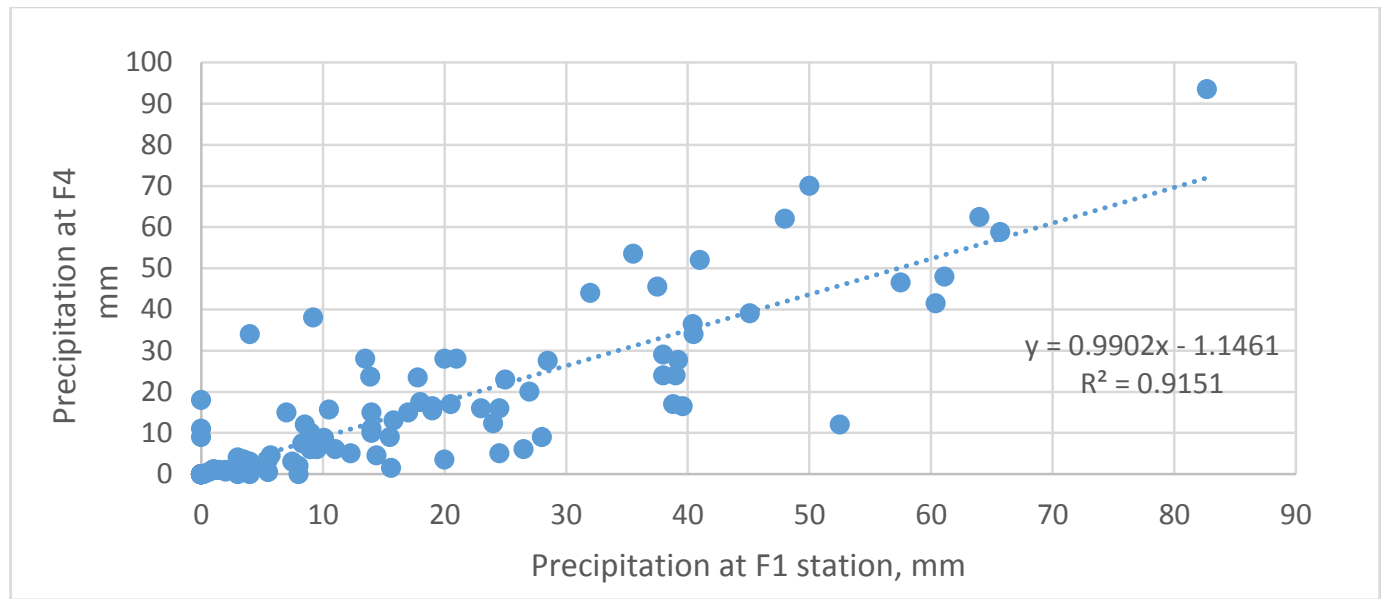

(a)

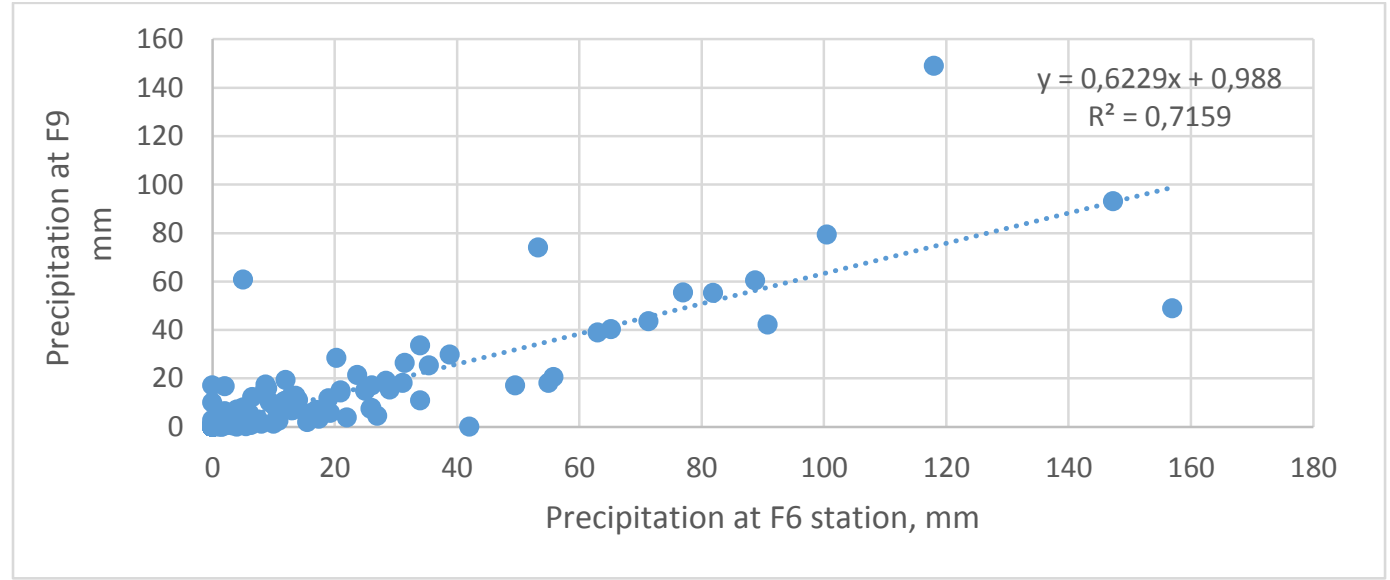

(b)

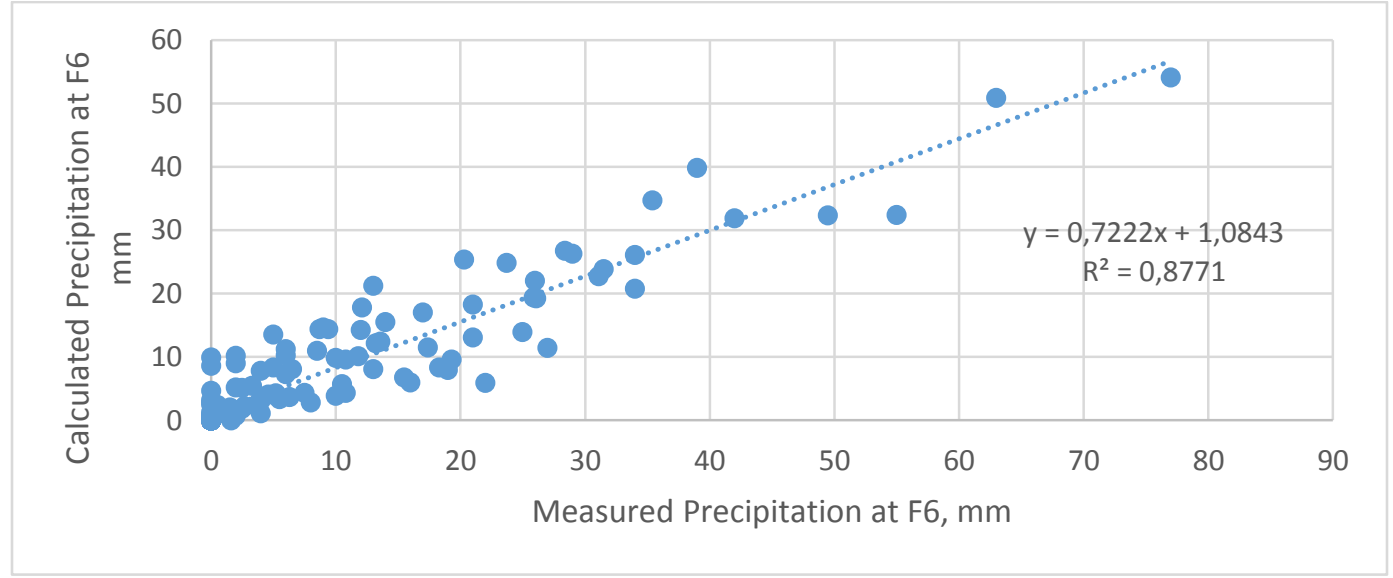

(c)

Fig. 4.4.a.b: Correlation between precipitation data of stations (F1-F4) and (F6-F9), c: Correlation between recorded and calculated precipitation at F6 station. 


\section{Thiessen polygons intersected with wadis}

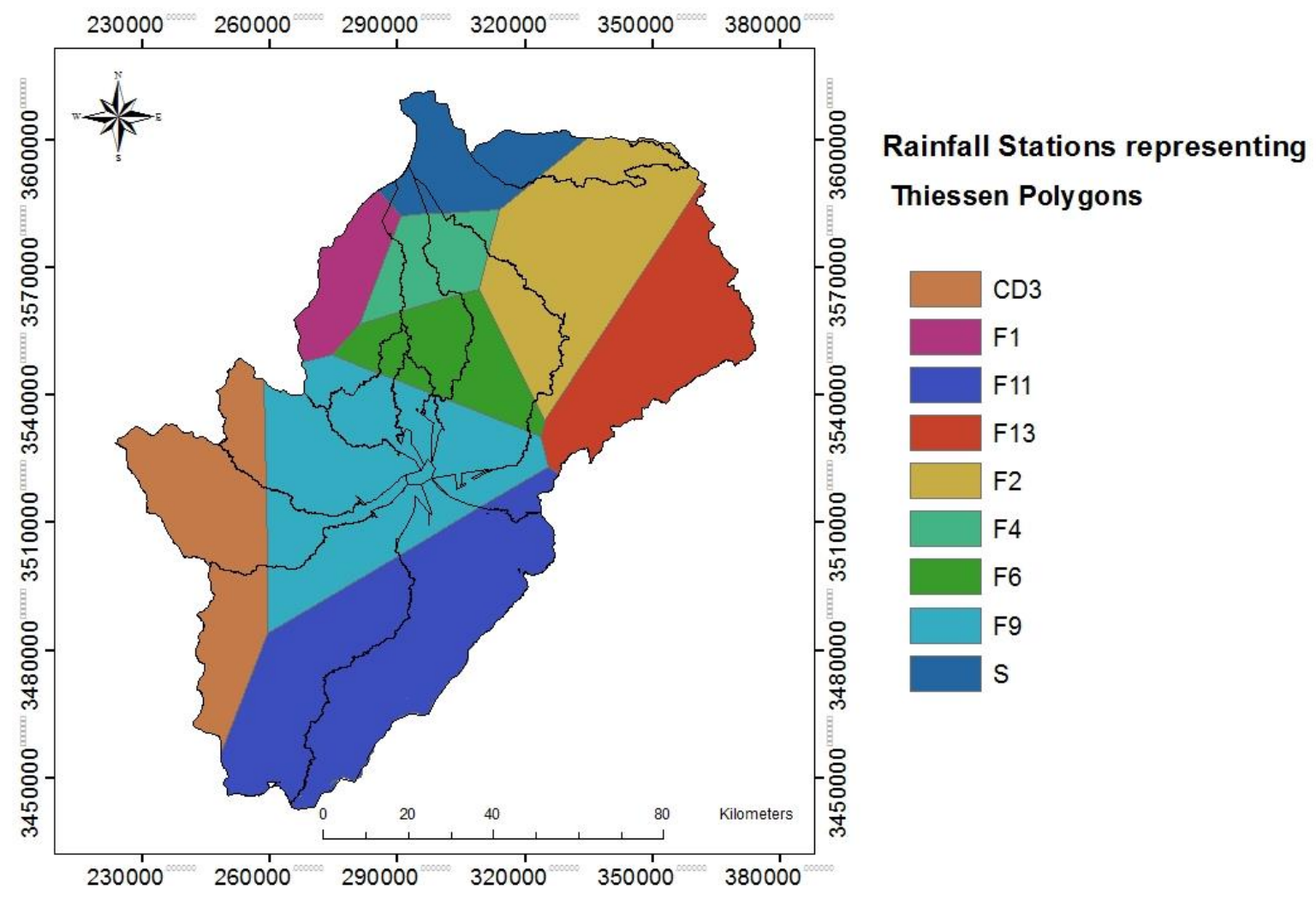

Fig. 4.5: Rainfall stations and Thiesen Polygons in Azraq basin

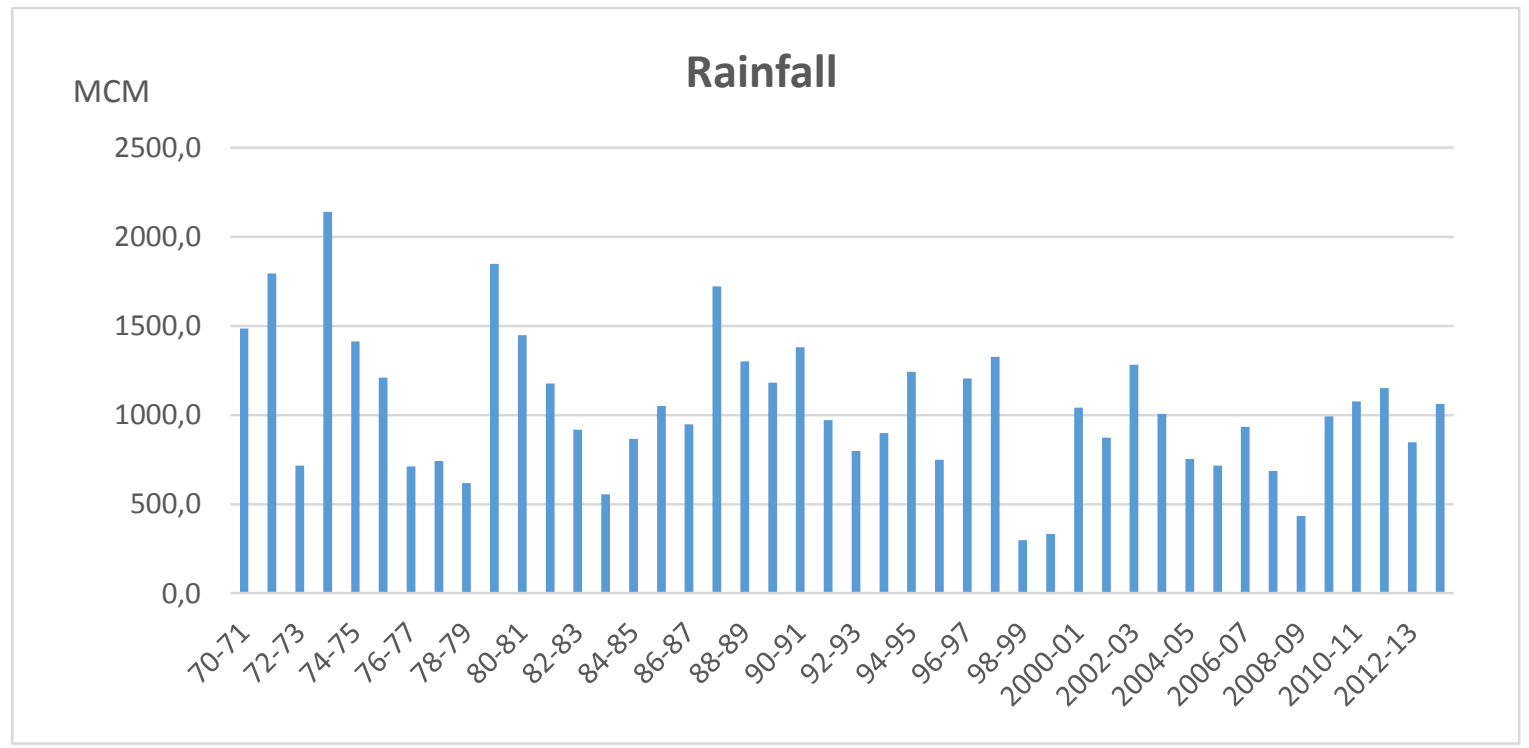

Fig. 4.6: Yearly rainfall volume in Azraq basin for the period (1970-2013). 


\subsection{Runoff}

Azraq basin is not gauged, and there are no detailed data of the amount of runoff generated from all wadis. The Curve Number method, developed by the USDA Soil Conservation Service (SCS, 1985), is used to calculate the runoff in the different wadis in the basin using equation (4.2).

$$
Q=\frac{\left(P-I_{a}\right)^{2}}{\left(P-I_{a}\right)+S}
$$

Where Q: is the direct surface runoff.

P: precipitation

$\mathrm{S}$ : is the potential maximum retention,

Ia: is the initial abstraction, Ia $=0.2 * \mathrm{~S}$

Runoff volume produced from each rainfall event was calculated using the $\mathrm{CN}$ values of each wadi, which were suggested by the WAJ (1989) through previous investigations. The antecedent moisture of the soil was accounted for in the calculation of runoff by using the normal, wet and dry CNs (Table 4.1).

Yearly volume of runoff generated from the basin is shown in Fig. 4.7. For the period 1970-2013 yearly surface runoff volume range between 1-126 MCM with an average value of $53 \mathrm{MCM}$. The records show a big variance and high interannual variability which poses difficulties on the management of this water resource.

\subsection{Evapotranspiration}

Considering the rarity of vegetation cover in Azraq, transpiration can be ignored in the calculation of the water budget in the basin. Evaporation measurements using Class A Pan are associated with errors in deserts as a result of accumulation of dirt in the pan, exposure to wind, birds drinking and other factors which makes Class A Pan reading more realistic to estimate evaporation from reservoirs. Overestimated values of Piche evaporation are expected as well when the atmometer is not shaded properly or in a windy weather (Van Zyl et al., 1989; Messing, 1998). 
Table 4.1: Wadis' Curve Numbers and Thiessen Polygon shares in Azraq basin

\begin{tabular}{|c|c|c|c|c|c|}
\hline Wadi & CN normal & CN wet & CN dry & Rain tation & Area Square Km \\
\hline \multirow[t]{3}{*}{ Unweind-Butum-Harth } & 83 & 93 & 67 & & 712.33 \\
\hline & & & & F9 & 494.79 \\
\hline & & & & CD3 & 217.54 \\
\hline \multirow[t]{3}{*}{ Mudeisisat } & 83 & 93 & 67 & & 1153.43 \\
\hline & & & & F9 & 340.25 \\
\hline & & & & $\mathrm{CD} 3$ & 813.19 \\
\hline \multirow{6}{*}{ Hassan } & 75 & 88 & 57 & & 625.85 \\
\hline & & & & F9 & 112.54 \\
\hline & & & & F1 & 19.41 \\
\hline & & & & $\mathrm{S}$ & 49.57 \\
\hline & & & & F6 & 267.60 \\
\hline & & & & F4 & 176.73 \\
\hline \multirow[t]{4}{*}{ Ghadaf } & 83 & 93 & 67 & & 2301.31 \\
\hline & & & & F9 & 501.04 \\
\hline & & & & CD3 & 459.60 \\
\hline & & & & F11 & 1340.67 \\
\hline \multirow[t]{3}{*}{ Jesha } & 83 & 93 & 67 & & 1360.51 \\
\hline & & & & F11 & 1288.70 \\
\hline & & & & F9 & 71.81 \\
\hline \multirow[t]{7}{*}{ Aseikhim } & 75 & 88 & 57 & & 1019.87 \\
\hline & & & & $\mathrm{S}$ & 18.19 \\
\hline & & & & F6 & 372.17 \\
\hline & & & & $\mathrm{F} 2$ & 194.74 \\
\hline & & & & $\mathrm{F} 4$ & 158.81 \\
\hline & & & & F12 & 1.53 \\
\hline & & & & F9 & 274.42 \\
\hline \multirow[t]{6}{*}{ Khanna-Rattam-Uniqya } & 75 & 88 & 57 & & 1227.96 \\
\hline & & & & F4 & 109.79 \\
\hline & & & & F9 & 475.55 \\
\hline & & & & $\mathrm{S}$ & 12.16 \\
\hline & & & & F1 & 447.97 \\
\hline & & & & F6 & 182.49 \\
\hline \multirow[t]{8}{*}{ Rajil } & 75 & 88 & 57 & & 3973.68 \\
\hline & & & & F9 & 163.79 \\
\hline & & & & F6 & 7.18 \\
\hline & & & & F11 & 92.06 \\
\hline & & & & $S$ & 603.26 \\
\hline & & & & F12 & 1349.66 \\
\hline & & & & F2 & 1671.94 \\
\hline & & & & $\mathrm{F} 4$ & 85.80 \\
\hline
\end{tabular}




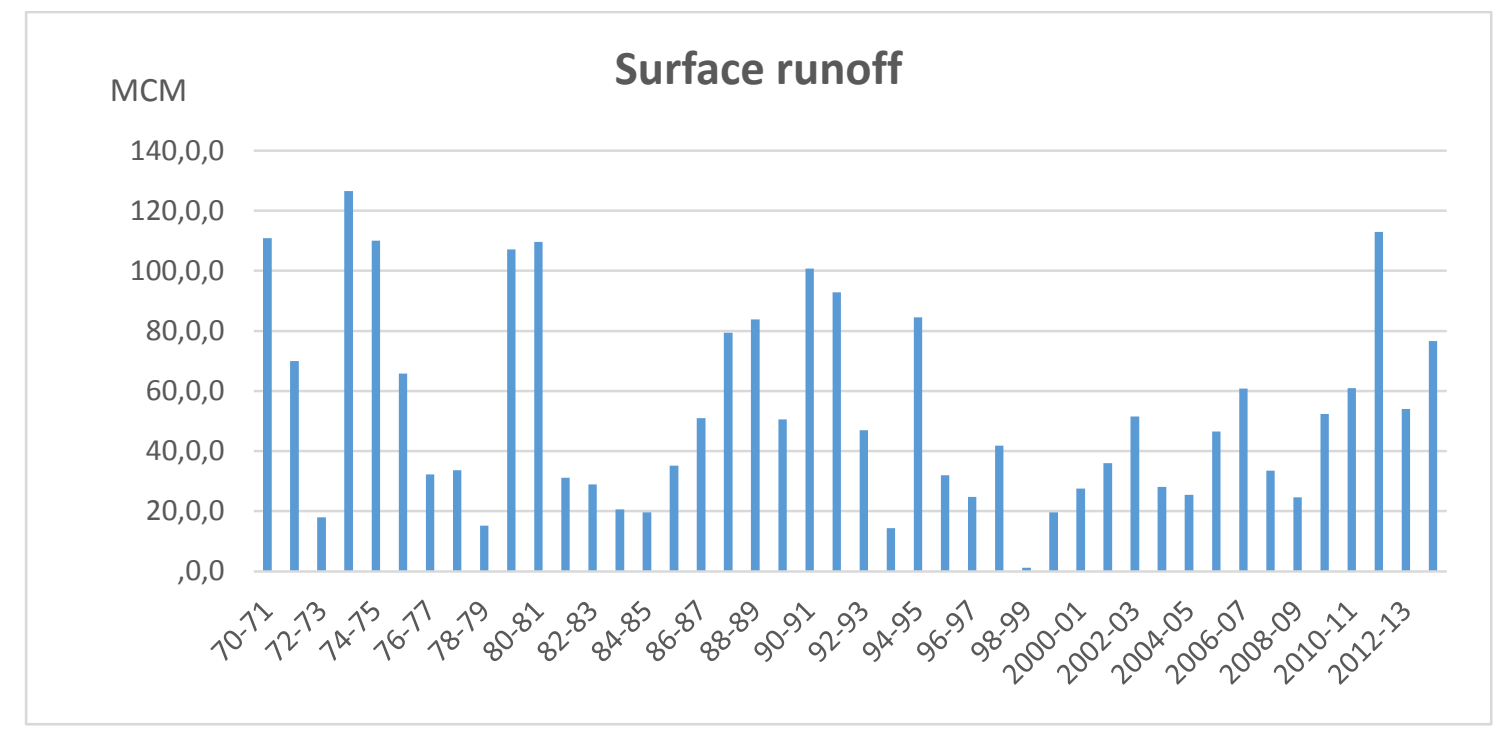

Fig. 4.7: Yearly runoff volume in Azraq basin for the period (1970-2013)

The Wundt and the Penman-Monteith-FAO equations are more commonly used in Jordan to calculate evaporation. In this study Penman-Monteith-FAO equation (Allen et al. 1998) is employed to calculate daily potential evaporation using the climatological records obtained from climate station F0009, the only climate station in Azraq basin, which exists in the middle of the basin.

Records of solar radiation (Rs) were highly interrupted and a lot of readings were missing, therefore, on days when shortwave radiation reading is missing measured duration of sunshine were used to calculate solar radiation using equation (4.3).

$$
R_{s}=\left(\mathrm{a}_{s}+b_{s} \frac{\mathrm{n}}{\mathrm{N}}\right) R_{a}
$$

Where:

Rs is solar (or shortwave) radiation (MJ/m2.day), $\mathrm{n}$ is the actual duration of sunshine (hour), $\mathrm{N}$ is the maximum possible duration of sunshine (hour), which can be estimated for each day of the year and for different latitudes on earth, $\mathrm{Ra}$ extraterrestrial radiation (MJ/m2.day) ] which can be estimated for each day of the year and for different latitudes on earth, 
as is the regression constant, expressing the fraction of extraterrestrial radiation reaching the earth on overcast days $(n=0)$,

$a s+b s$ fraction of extraterrestrial radiation reaching the earth on clear days $(n=N)$. The values of as and bs are 0.25 and 0.5 respectively.

On days where both readings (radiation and sunshine duration) were missing minimum and maximum temperature $\mathrm{T} \min$ and $\mathrm{T} \max (\mathrm{C})$ were used to calculate the solar radiation using equation (4.4).

$$
R_{s}=K_{R s} * R_{a} \sqrt{\left(T_{\max }-T_{\min }\right)}
$$

Where:

KRs: is an adjustment coefficient ( 0.16 for Azraq basin )

$\mathrm{Ra}$ : extraterrestrial radiation (MJ m-2 d-1).

The wind speed at Azraq station is measured at a height of $2 \mathrm{~m}$ and therefore no adjustment was needed.

F0009 station doesn't measure relative humidity. Wet and dry bulb temperature were used to calculate the daily actual vapor pressure using equation (4.5).

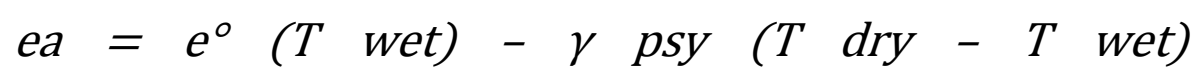

Where:

ea is actual vapor pressure $(\mathrm{KPa})$,

$\mathrm{T}$ dry and $\mathrm{T}$ wet are dry and wet bulb temperature respectively $(\mathrm{C})$.

$\gamma$ psy is The psychrometric constant of the instrument $(\mathrm{KPa} / \mathrm{C})$ given by: $\gamma$ psy $=$ apsy*P

where $\mathrm{P}$ is the atmospheric pressure (Kpa C-1) estimated based on the elevation of Azraq climate station $(\mathrm{z}=521 \mathrm{~m})$, and a psy is 0.0008 for the Azraq climate station (natural ventilated psychometer).

$\mathrm{e}^{\circ}(\mathrm{T}$ wet) is the saturation vapor pressure at the wet bulb temperature (KPa).

Saturation vapor pressure at any temperature $\mathrm{T}$ is a function of air temperature and can be calculated using equation (4.6). 


$$
e^{\circ}(T)=0.6108 \exp \left(\frac{17.27 T}{T+237.3}\right)
$$

using Penman-Monteith-FAO equation (equation 4.7), reference potential evapotranspiration EVT0 is calculated.

$$
\text { EVTO }=\frac{0.408 \Delta(R n-G)+\gamma\left(\frac{900}{T+273}\right) u_{2}(e s-e a)}{\Delta+\gamma\left(1+0.34 u_{2}\right)}
$$

$\mathrm{u} 2$ is wind speed at $2 \mathrm{~m}$ height $(\mathrm{m} / \mathrm{sec})$.

T mean daily temperature (c)

ea actual vapor pressure (Kpa)

es saturation vapor pressure (Kpa)

$\gamma$ psychometric constant $(\mathrm{Kpa} / \mathrm{C})=0.000665 \mathrm{P}$

$\Delta$ is the slope of saturation vapor pressure-temperature curve and is calculated using equation (4.8).

$$
\Delta=\frac{4098\left(0.6108 \exp \left(\frac{17.27 T}{T+237.3}\right)\right)}{(T+237.3)^{2}}
$$

$\mathrm{Rn}$ is net radiation at the surface ( $\mathrm{MJ} / \mathrm{m} 2$.day) which equals net shortwave radiation Rns minus net longwave radiation $\mathrm{RnI}$.

Net shortwave radiation is the balance between incoming and reflected solar radiation. The reflectance of radiation is expressed using albedo reflection coefficient $\alpha$ (assumed to be 0.18 for Azraq area).

$$
R n s=(1-\alpha) R s
$$

Net longwave radiation is calculated from equation (4.10)

$$
R n I=\sigma\left[\frac{T \max K^{4}+T \min K^{4}}{2}\right]\left(0.34-0.14 \sqrt{e_{a}}\right)\left(1.35 * \frac{R_{S}}{R_{s o}}-0.35\right)
$$

Where :

$\sigma$ is Stefan-Boltzmann constant [4.903*10-9 MJ K-4 m-2 day-1]

Tmax $\mathrm{K}$ and Tmin $\mathrm{K}$ are maximum and minimum temperature $\left[\mathrm{K}={ }^{\circ} \mathrm{C}+273.16\right]$. 
Rso is calculated clear-sky radiation $(\mathrm{MJ} / \mathrm{m} 2$.day); $\mathrm{Rso}=(0.75+2 * 10-5 \mathrm{z}) \mathrm{Ra}$, ( $\mathrm{z}$ is the station elevation; $521 \mathrm{~m}$ ).

Fig. 4.8 shows calculated long-term average values of potential EVT0 (mm/day) for every month using the Penman-Monteith-FAO equation. It shows that the maximum EVT0 occurs in July, while the minimum occurs in December.

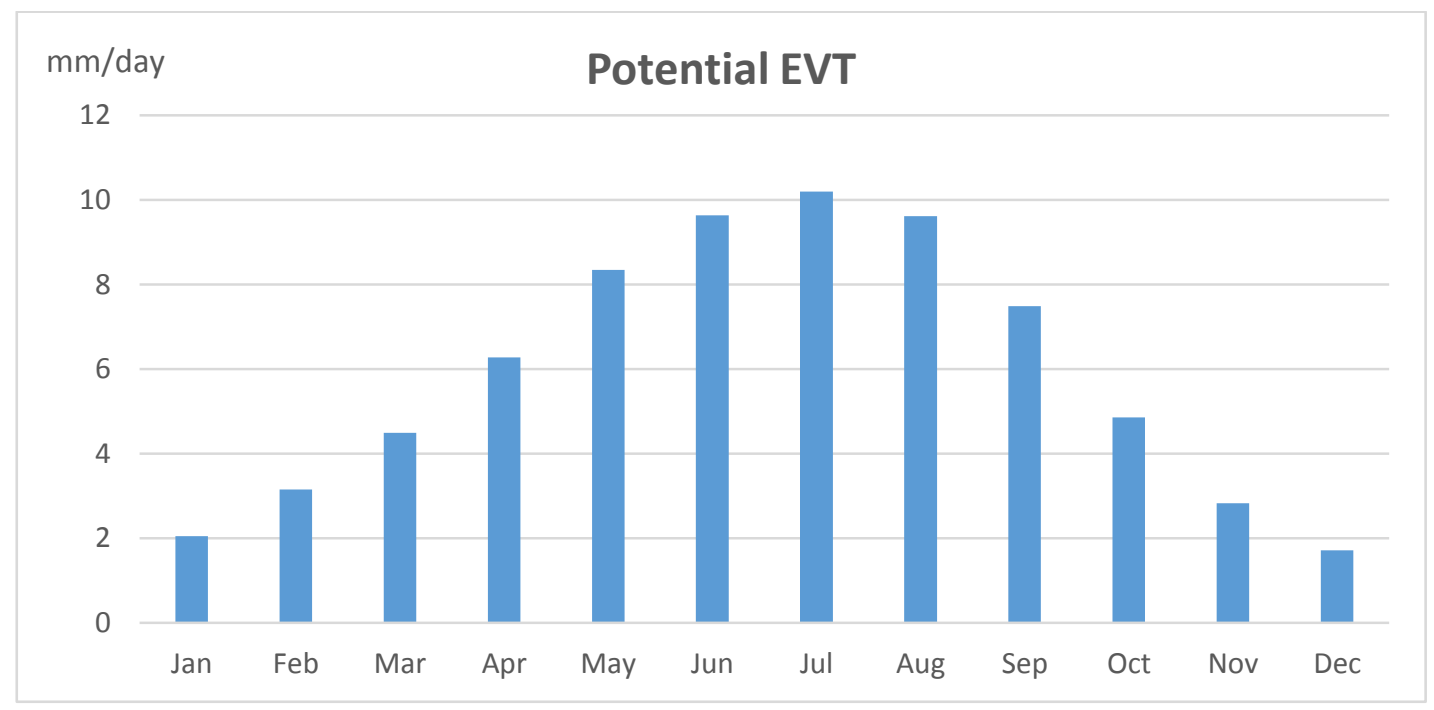

Fig. 4.8: Long-term average EVT0 in Azraq basin for every month

Due to the scarcity of the vegetation cover in the basin, no coefficient was used, and the calculated values of daily EVT0 were used directly for the calculation of the water budget in the basin.

For those storms exceeding the initial abstraction and on the day of the storm the actual EVT equals potential EVT assuming the soil moisture has reached its saturated state. On the following days, evaporation will still occur, but actual EVT will be less than potential EVT and is governed by factors related to the soil type such as field capacity and wilting point.

An approximation of actual ET was made in this study by assuming that actual ET equals $80 \%, 60 \%, 40 \%$ and $20 \%$ of the potential EVT on the second, third, fourth and fifth day respectively. 


\subsection{Groundwater recharge}

Groundwater recharge was estimated using the water budget method on a daily basis and for every storm event using equation (4.11).

$$
\Delta S=P-R-E v t-I a
$$

$\Delta \mathrm{S}$ is the change in groundwater storage

$P$ precipitation

$\mathrm{R}$ surface runoff

Evt evapotranspiration

Ia initial abstraction.

Fig. 4.9 shows that for the period 1970-2013, groundwater recharge volume in the basin range between $4-133 \mathrm{MCM} / \mathrm{year}$ with an average of $39.9 \mathrm{MCM} / \mathrm{year}$ showing a big variance. Long term average of rainfall and groundwater recharge (mm/year) for each wadi are shown in Table 4.2. Yearly rainfall and groundwater recharge (mm) in each wadi of Azraq basin are shown in Appendix B.

From Table 4.2, it can be seen that groundwater recharge constitutes between 1.3 and $6.7 \%$ of total rainfall which is in accordance with groundwater recharge estimations in Jordan (MWI and GTZ, 2008).

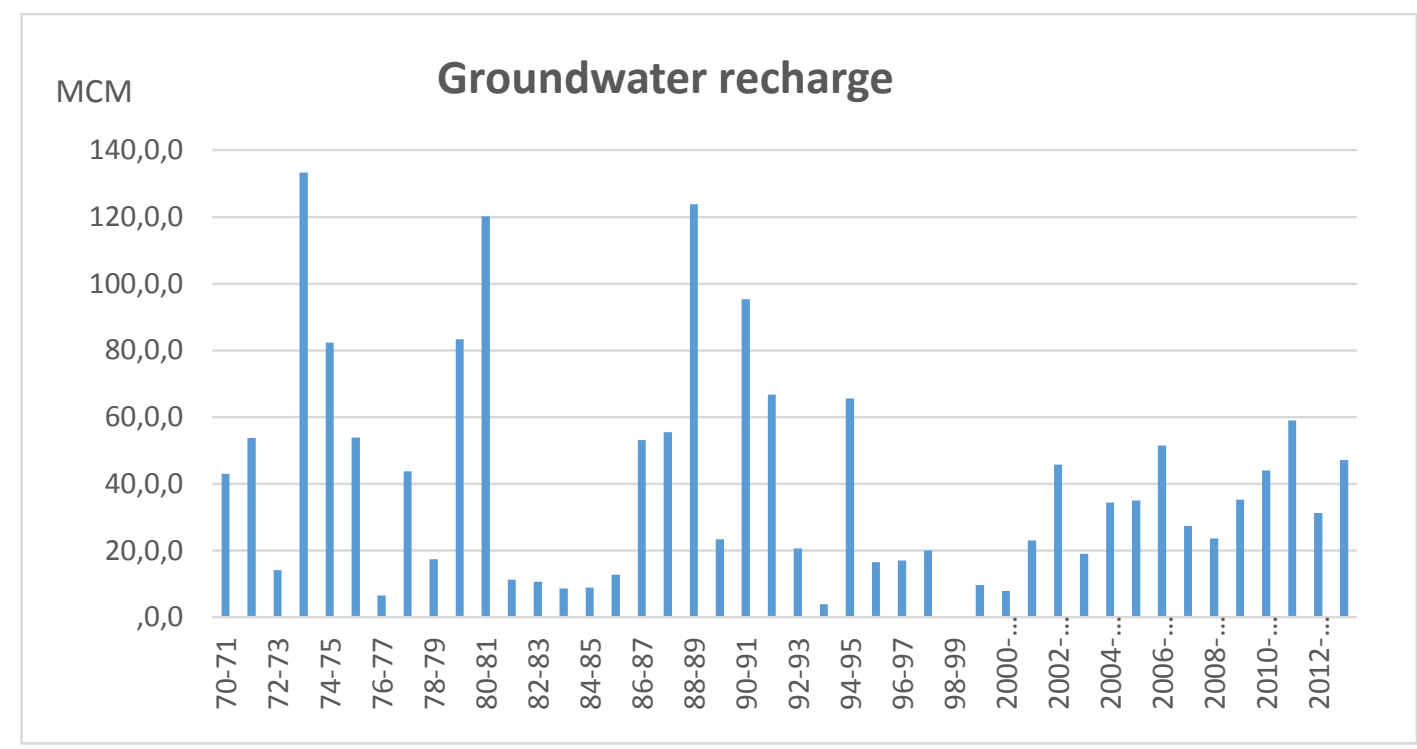

Fig. 4.9: Yearly groundwater recharge volume in Azraq basin for the period (19702013). 
Table 4.2: Long term average of rainfall and groundwater recharge $(\mathrm{mm} / \mathrm{year})$ for Azraq basin's wadis

\begin{tabular}{|c|c|c|c|}
\hline Wadi & $\begin{array}{c}\text { Rainfall } \\
\text { mm/year }\end{array}$ & $\begin{array}{c}\text { Recharge } \\
\text { mm/year }\end{array}$ & $\begin{array}{c}\text { Percentage of rainfall } \\
\text { as recharge } \%\end{array}$ \\
\hline Jesha & 42.5 & 1.2 & 2.8 \\
\hline Aseikhim & 102.7 & 2.0 & 1.9 \\
\hline Rajil & 98.6 & 3.6 & 3.6 \\
\hline Unweind-Butum-Harth & 81.0 & 4.2 & 5.2 \\
\hline Mudeisisat & 119.0 & 8.0 & 6.7 \\
\hline Hassan & 133.9 & 3.8 & 2.9 \\
\hline Ghadaf & 65.1 & 2.9 & 4.4 \\
\hline Khanna & 107.2 & 2.1 & 1.9 \\
\hline Rattam & 55.8 & 0.7 & 1.3 \\
\hline Uniqya & 57.3 & 0.8 & 1.3 \\
\hline
\end{tabular}




\section{Development of groundwater flow model for Azraq basin}

\subsection{Introduction}

In order to gain an understanding of the system under study, and how it would behave under certain management options, a groundwater flow model is employed. A model is defined as a device which represents an approximation of a field situation. Mathematical models simulate groundwater flow indirectly by means of a governing equation thought to represent the physical processes that occur in the system (Anderson and Woessner, 1992).

Several models have been built and calibrated for Azraq basin. Alongside unpublished works stored at the Ministry of Water and Irrigation in Jordan, (Abdulla et al., 2000) (Al-Kharabsheh,2000) and (Abu-El-Sha'r and Hatamleh, 2007) built and calibrated groundwater flow models for the Azraq basin.

In this study, a new model is going to be built and calibrated for the Azraq basin. A Larger model domain will be adopted that includes the recharge area in the north. The geology of the basin will be considered during the calibration process.

\subsection{Governing equations}

The most commonly used flow equation for describing three-dimensional, saturated flow in terms of the single variable, $\mathrm{h}=\mathrm{h}(\mathrm{x}, \mathrm{t})$ is;

$$
S s(\partial h / \partial t)=\nabla \cdot(K \cdot \nabla h)
$$

h: Piezometric head (L)

K: Hydraulic conductivity (L/T).

Ss: Specific storage $\left(\mathrm{L}^{-1}\right)$

For a homogeneous isotropic porous medium and under a steady state conditions this equation is reduced to Laplace equation (5.2).

$$
\nabla^{2} h=0
$$




\subsection{Code and software}

Except for very simplified conditions, an analytical solution of groundwater flow equations is difficult, if not impossible to obtain. Numerical methods (e.g. finitedifference, finite volume and finite elements) are employed by many codes to solve the flow equation.

In this study, the model was constructed using the modular three-dimensional finite difference groundwater flow code developed by the United States Geological Survey (USGS) commonly known as MODFLOW (McDonald and Harbaugh, 1988, and Harbaugh and McDonald, 1996). Visual Modflow 3.1.0 was used for the purpose of data pre- and post-processing.

\subsection{Conceptual model}

The majority of groundwater abstraction takes place in the Shallow Aquifer System, while the middle and deep aquifers are hardly exploited. A downward as well as upward flow takes place between the upper and middle aquifers. The groundwater system in the study area is modelled as 3-layered-system representing the Shallow and Middle Aquifer Systems and the aquitard separating them (Fig. $5.1)$.

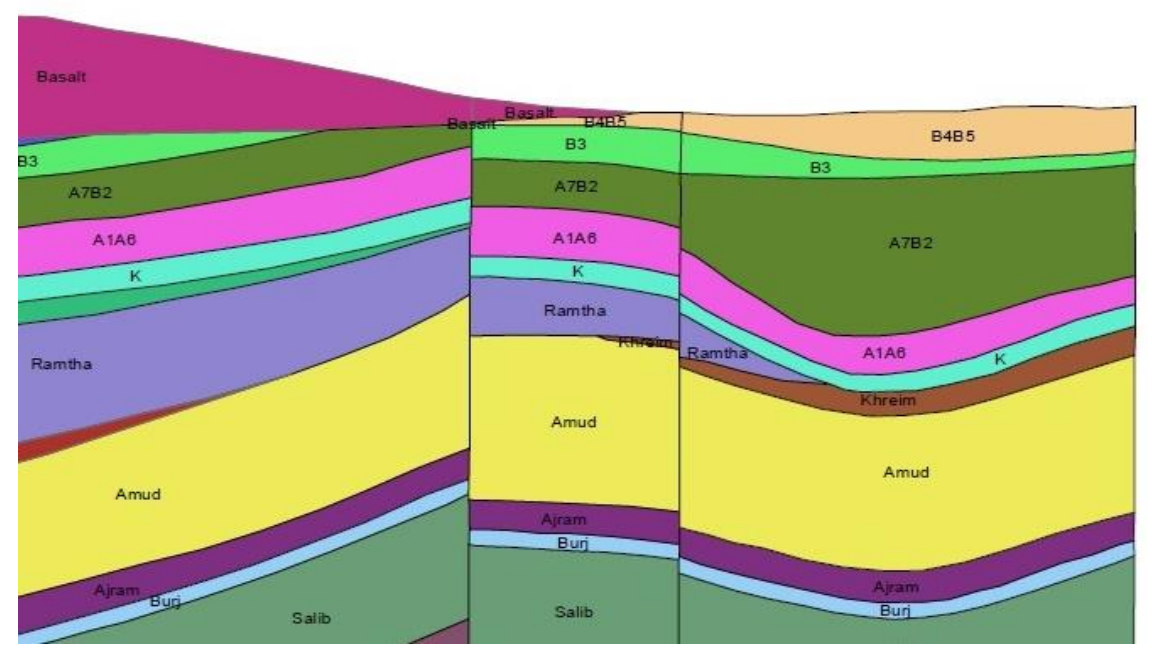

Layer 1: Shallow Aquifer System (Basalt and B45)

Layer 2: Aquitard B3

Layer 3: Middle Aquifer System (B2A7)

Fig. 5.1: Conceptual model for Azraq basin 


\subsection{Numerical model setup}

\subsubsection{Model domain and spatial discretization}

The model domain covers an area of 8672 square $\mathrm{km}$ and lies between left lower corner $(454000,478000)$ and right upper corner $(518000,613500)$ in Jordan coordination.

For the finite-difference solution the area of interest is divided into a grid of blocks called cells where every single cell is described in terms of row-column-layer.

Within every cell there is a point called "node" at which the head is calculated. MODFLOW is a block-centered finite-difference code where the nodes are located in the center of the cells (McDonald and Harbaugh, 1988).

In this study, the model area was divided into 75 rows and 58 columns. The dimensions of cells vary from $(2000 * 2500) \mathrm{m}$ to $(700 * 750) \mathrm{m}$ depending on their location. Cells in the central area where pumping wells take place were made finer.

\subsubsection{Temporal discretization}

During a transient simulation, the distribution of heads is simulated at a time interval called the time step. Certain solution techniques have limits on the size of the time step in order to ensure a stable solution (e.g. explicit methods). In MODFLOW, the system of equations is solved iteratively based on heads which belong only to the new time steps (fully implicit scheme) and in such solution techniques no restriction on time steps is set. Other factors such as the response of the aquifer, the quality of data and others can play a role in determining the time step.

To the author knowledge, all models executed before in the area used a stress period of one year due to the quality of abstraction data provided by the MWI as yearly lump sums. In this study transient modeling is performed at a stress period and time step of one-month for a better representation of the seasonal variation in groundwater table.

\subsubsection{Stratigraphy modelling}

The elevations of the base of the Shallow Aquifer System, B3 aquitard and the Middle Aquifer System were obtained from (MWI, 2013). Contour maps of aquifer bases is shows in Appendix C. Elevation of aquifer bases was imported into the model to represent the thickness distribution of model layers. 


\subsection{Boundary conditions}

Boundaries conditions are mathematical statement specifying the dependent variable (head) or its derivative (flux) at the boundaries of the problem domain (Anderson and Woessner, 1992).

Boundary conditions were identified based on the groundwater flow patterns of the shallow and the middle aquifers. Fig. 5.2 illustrates the boundary conditions for the upper and middle aquifers. For the Shallow Aquifer System, the west boundary of the model, where the aquifer reaches its saturation limit, is set to a no- flow boundary. The water divide delineating the basin borders at the north and northwest were simulated as no flow boundary. No flow boundaries were also assigned at the north-east of the model area where groundwater flow is parallel to this boundary, and at the water divide south east. The rest of the model boundaries were initially set as constant-head boundaries during the steady-state calibration, and were later converted into general head boundaries during the transient calibration to minimize the impacts of boundary condition on the simulation results.

North-western, north-eastern and south-eastern boundaries of the Middle Aquifer System coincide with groundwater divides, and were simulated as no flow boundaries. The rest of the model boundaries for the middle aquifer system were simulated as constant-head boundaries

\subsection{Model input and output}

\subsubsection{Groundwater recharge}

Apart from water flowing in through the boundaries we set, recharge with rain water is the only input we have in our study area. Return flow and seepage from surface water irrigation or in urban areas were neglected.

Monthly values of groundwater recharge have been calculated in this study for each Wadi using the simple approach of water budget (Chapter 4). For the steadystate model, long-term average of groundwater recharge in the period 1970-1980 calculated for each wadi were imported. The calculated monthly values of groundwater recharge in each wadi were imported in the transient model. 

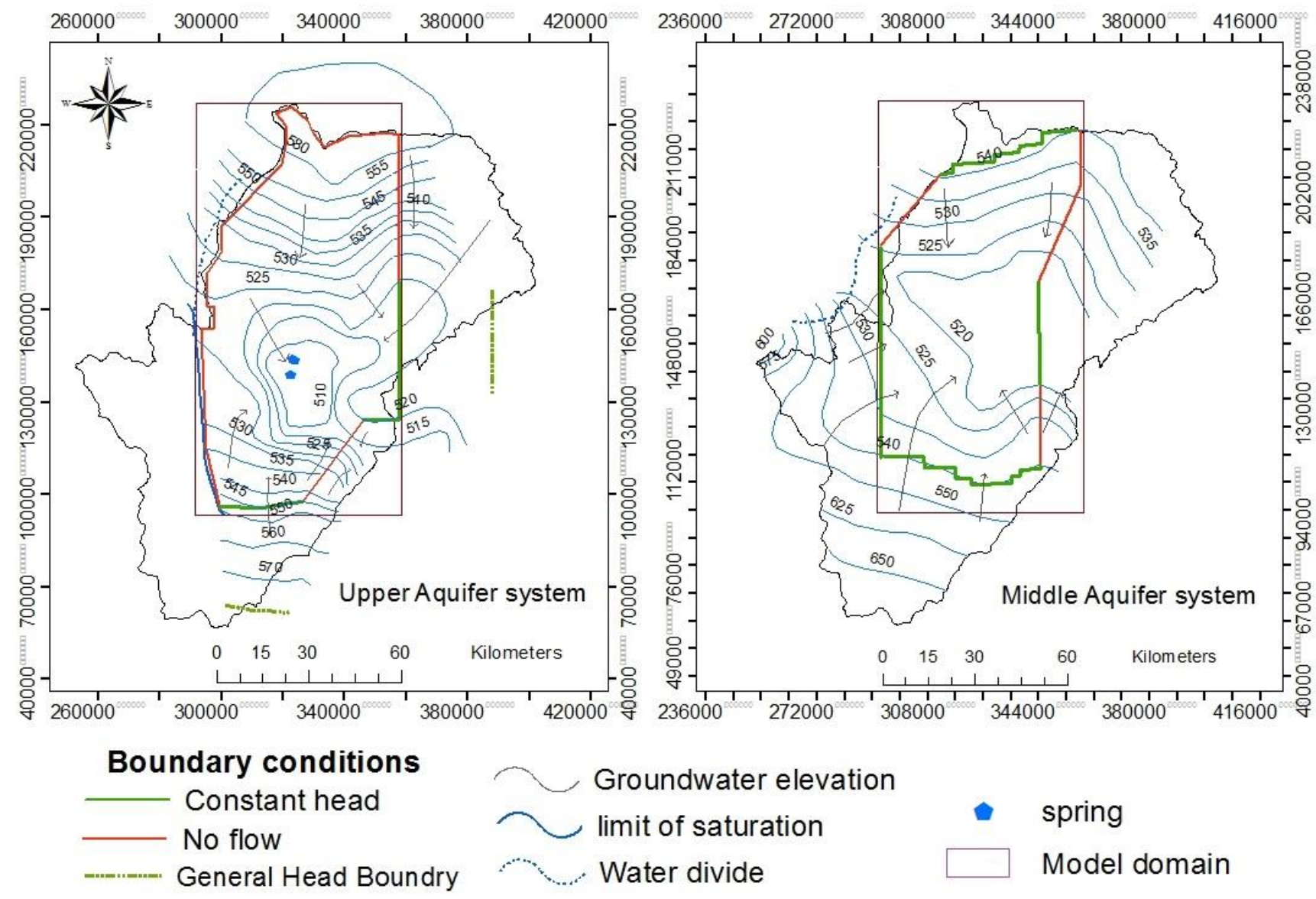

spring

Model domain

Fig. 5.2: Model domain and boundary conditions

\subsubsection{Springs and abstraction}

Beside the water that flows out through the boundary conditions we set, water leaves the model through springs and pumping wells. For the steady state period, pumping from the basin was neglected. The only output was spring discharge. Fig. 2.9 shows monthly discharge of springs in the basin, which stopped in 1990. As no records of springs discharge were available in the seventies, springs discharge in the year 1981 was considered to be representative for the steady-state as in that year water pumping was still very limited. For the transient simulation, springs were simulated as drain boundary, and used for calibration.

For transient simulation, abstraction was neglected for the period 1960-1980. Monthly values of abstraction rates from the different wells in the model area during the period 1981-2012 were imported into the model. Data on water abstraction was provided as yearly lump-sums. Abstraction was assumed to take 
place in summer and spring only and to be uniformly distributed within these two seasons. Abstraction rate through governmental and private wells are shown in Fig. 2.12a,b.

According to (WAJ regional office, 2010) the number of illegal wells in the last years has been continuously increasing (Mesnil and Habjoka, 2012). Estimated yearly values of illegal abstraction imported in the model are about $10 \mathrm{MCM} / y e a r$ for the period 2004-2007 and 20 MCM/year for the period 2008-2012.

\subsection{Model calibration}

Calibration is defined as finding a set of parameters, boundaries conditions and stresses that produces simulated heads and fluxes which corresponds to fieldmeasured values by solving the inverse problem (Anderson and Woessner, 1992). In this study, model calibration is performed to steady-state and transient state data set.

\subsubsection{Steady-state calibration}

In the steady-state calibration, the values of hydraulic conductivity were adjusted for the shallow and middle aquifers by means of trial and error until the distribution of simulated heads reasonably matched the distribution of measured heads in the basin prior to any substantial pumping occurring.

\subsubsection{Transient calibration}

Transient calibration was performed under the boundary conditions, input and output, periods and time step mentioned above. In the first transient model (period 1960-1980) the long term average of springs discharge was used for calibration. Values of hydraulic conductivity calibrated in the steady state were slightly adjusted until the simulated springs discharge matched the measured value.

In the second transient model (1980-2012) groundwater table decline recorded at 5 head-observation wells in the shallow aquifer system, see Fig. 2.2 along with the discharge of springs and their dry out in 1991 were used for the calibration of the specific yield (Sy) of the shallow aquifer system. Time series data on water decline was incomplete for all monitoring wells.

Pumping from the middle aquifer system is minimal and no time-series data on the fluctuation of the piezometeric head are available, therefore, the aquifer was assumed to remain under the steady state conditions. 


\subsubsection{Calibration results}

A reasonable match between observed and simulated heads for the steady-state period was obtained. For the shallow aquifer system, one area of hydraulic conductivity covers the Basalt aquifer in the north, and two areas cover the B45 carbonate aquifer in the south. The second area of $\mathrm{K}$ was needed to represent the high permeability area of converging conduits around the karstic springs.

Calibrated values of $\mathrm{K}$ were slightly adjusted in the first transient model until the simulated spring discharge matched the measured long-term average value.

In the second transient simulation phase (1981-2012), a reasonably good match between simulated and measured hydrographs for water table decline in monitoring wells as well as between simulated and measured springs discharge was obtained, see Fig. 5.3 and Fig. 5.4. For observation well F1280 simulation results show no seasonal fluctuations in contrast to measured values. This well is located in the highly fractured basalt aquifer and water table fluctuation is governed by the flow through fractures and preferential flow paths, which cannot be well represented using the one-continuum modeling approach.

The one continuum approach failed as well to accurately simulate the discharge and dry-out of springs as the flow occurs through the highly karstified zone around the springs. Table 5.1 shows the $\mathrm{K}$ and Sy values for the different aquifers.

The model's water balance under steady-state conditions is shown in Fig. 5.5.

Table 5.1: Calibrated hydraulic conductivity and specific yield of the shallow and middle aquifers

\begin{tabular}{|c|c|c|}
\hline Formation & K, m/day & SY \\
\hline Upper aquifer, basalt & 15 & 0.002 \\
\hline Upper aquifer, carbonate B45 & $1.2,30$ & 0.02 \\
\hline Middle aquifer & $0.25,30$ & - \\
\hline
\end{tabular}



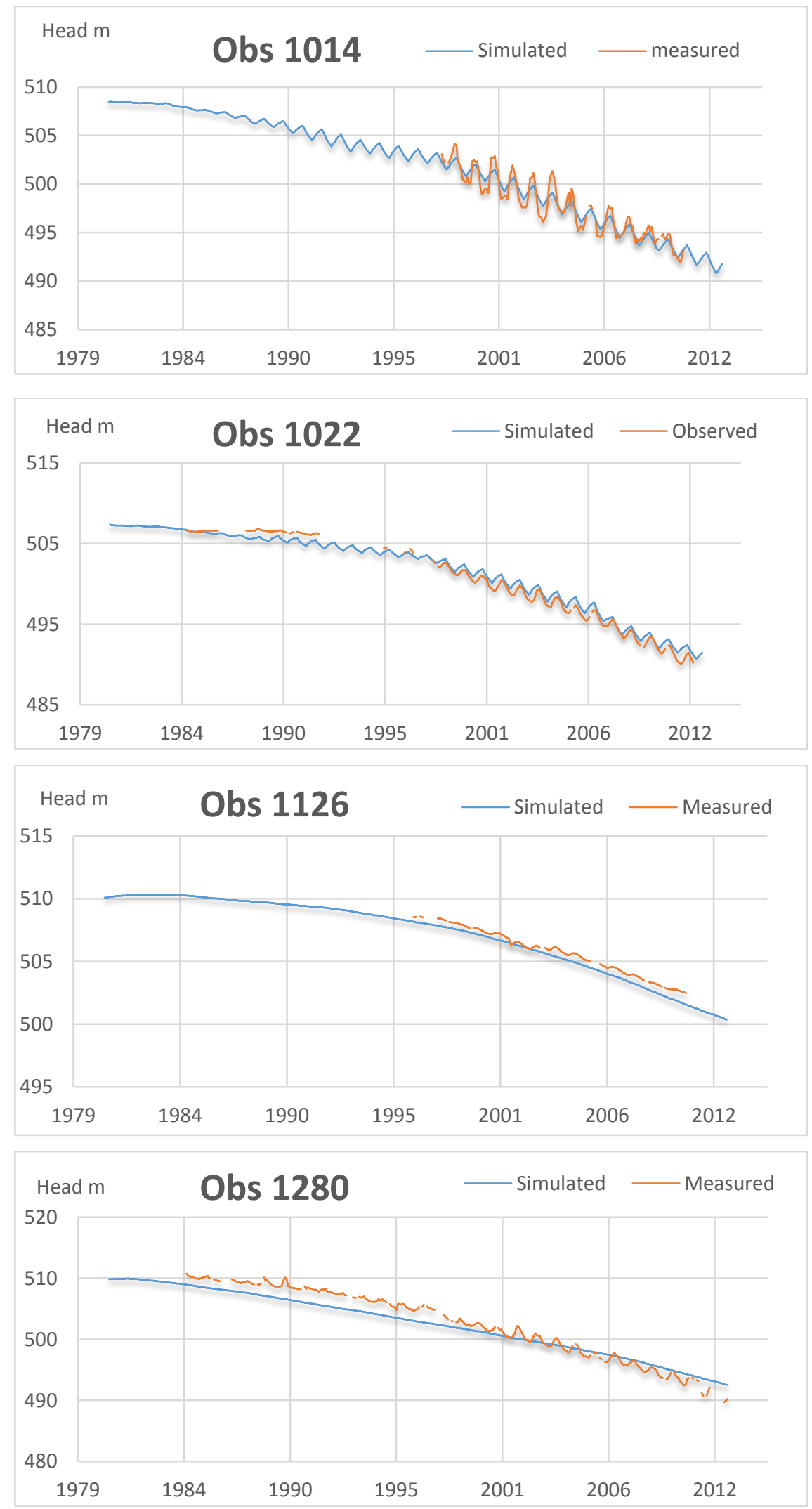

Fig. 5.3: Results of transient calibration, observed versus calculated groundwater head in monitoring wells 


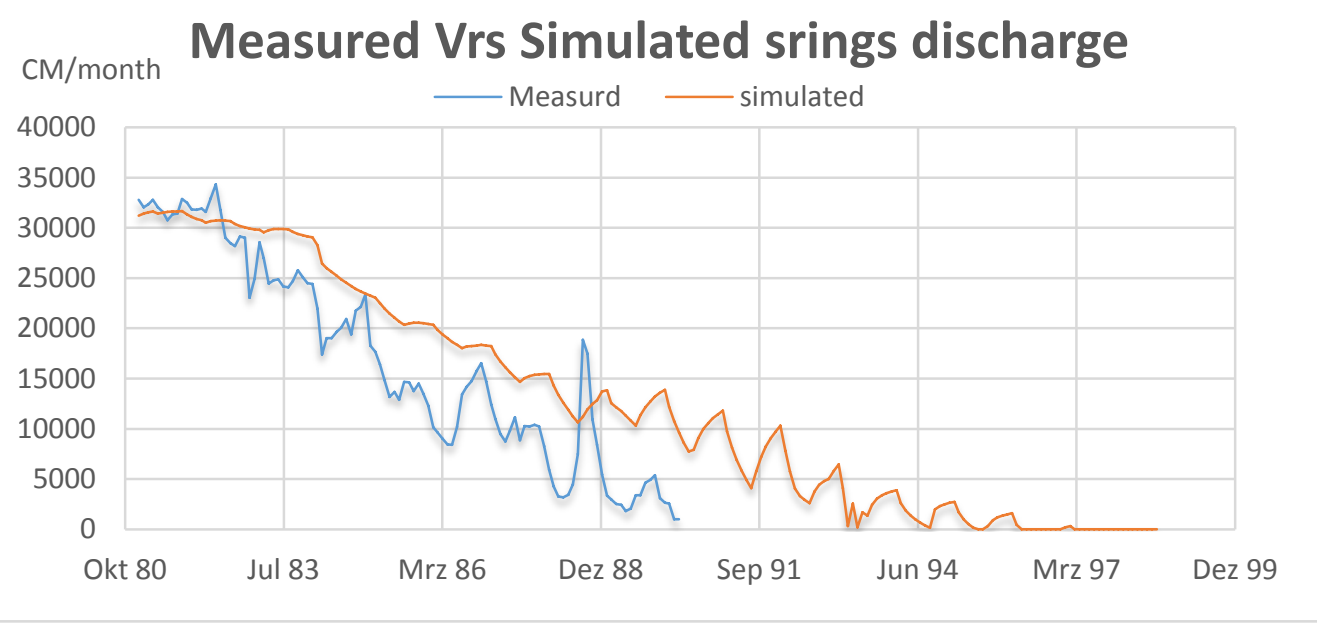

Fig. 5.4: Results of transient calibration, observed versus simulated springs discharge

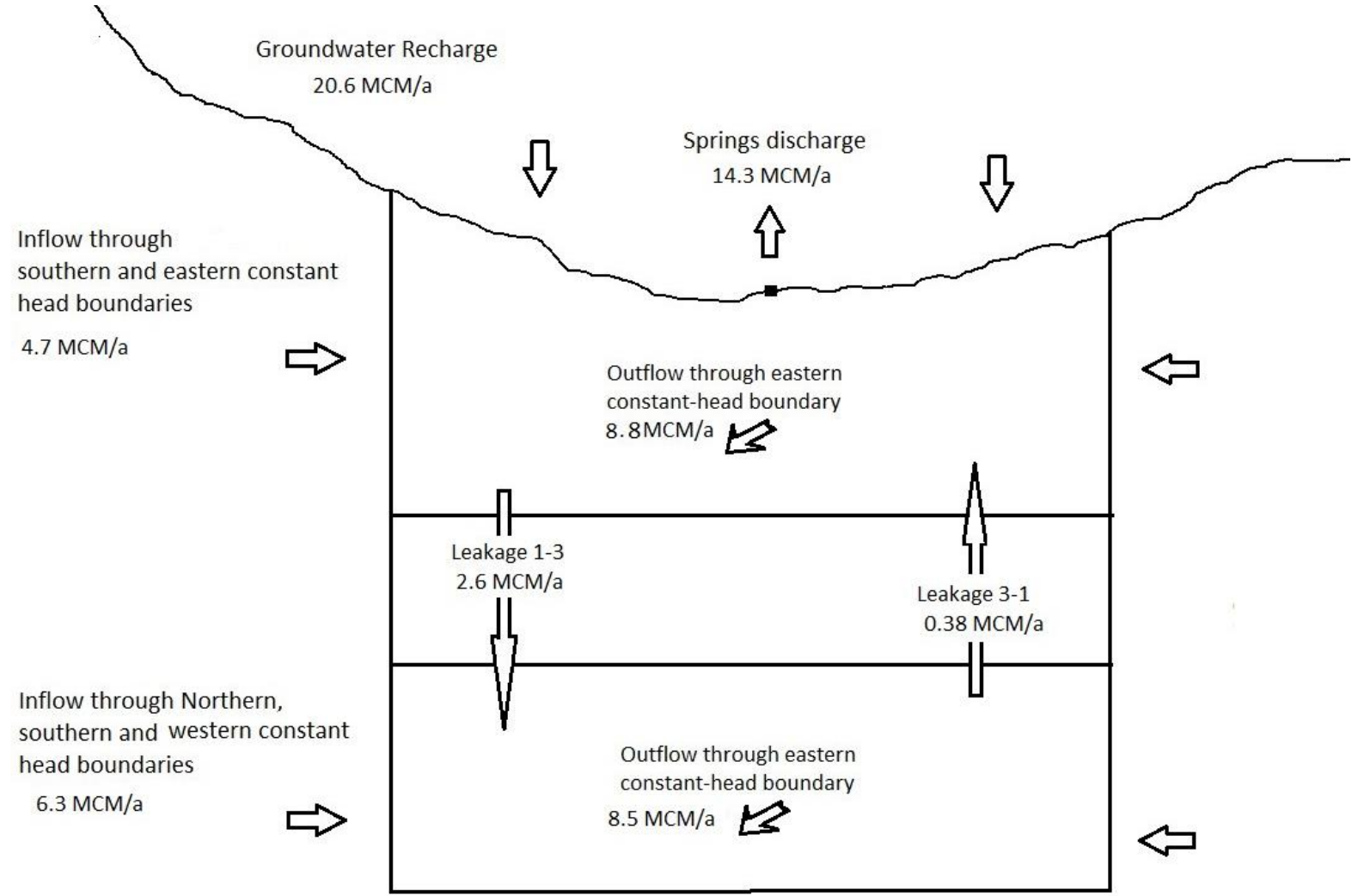

Fig. 5.5: Water balance of the steady-state model 


\subsection{Sensitivity analysis}

sensitivity analysis is carried out in order to quantify the effect of uncertainty in the calibrated model caused by uncertainty in the estimates of aquifer parameters (Anderson and Woessner 1992). The sensitivity of a calibrated parameter is obtained by increasing/decreasing the value of this parameter at a certain increment while holding the other parameters fixed, and realizing the impacts of this change on the results.

PEST is an external parameter estimation software implemented by Hill and others (Hill, 2000) and upgraded by Doherty (2001). It is used often in hydrogeological modeling to estimate parameters' values through an optimization process where an objective function composed of the sum of squared deviations between modelcalculated and observed hydraulic heads or drawdowns is minimized.

During every optimization iteration the model is run once for each adjustable parameter, and the derivatives of observations with respect to parameters are calculated (the Jacobian matrix), and then the composite sensitivity of each parameter is recorded.

The composite sensitivity $\mathrm{S}$ of a parameter $\mathrm{i}$ is defined as

$$
\mathrm{S}_{i}=\left(J^{t} Q J\right)_{i i}{ }^{1 / 2} / m
$$

where:

$\mathrm{J}$ is the Jacobian matrix whose each column lists the derivatives of all "modelgenerated observations" with respect to a particular parameter.

$\mathrm{Q}$ is the "cofactor matrix", a diagonal matrix whose elements are comprised of the squared observation weights.

$\mathrm{m}$ is the number of observations with non-zero weights.

Thus the composite sensitivity of the $i$ 'th parameter is the normalized (with respect to the number of observations) magnitude of the column of the Jacobian matrix pertaining to that parameter, with each element of that column multiplied by the weight pertaining to the respective observation. Obtaining the composite sensitivity from PEST run can save the modeler the tedious task of adjusting certain model inputs, running the model, reading the outputs, recording their values, and going through the same cycle again.

At the beginning of a PEST run a set of initial parameter values must be supplied; these are the values that PEST uses at the start of its first optimization iteration. In 
order to calculate their sensitivity, the manually calibrated values of $\mathrm{K}$ and Sy are fed to PEST, and the transient model is run. The sum of squared weighted residuals, Jacobian matrix and composite sensitivity are calculated at the first iteration. The composite sensitivity of horizontal hydraulic conductivity and the specific yield of the shallow aquifer systems, have been obtained (Table 5.2).

It is realized that $\mathrm{K}$ and Sy of the B45 have the highest value of composite sensitivity which indicates a decreased uncertainty in estimating these values. Additionally, the model is sensitive to hydraulic conductivity of the Basalt formation

Table 5.2: Composite sensitivity of $K$ and Sy values for the Shallow Aquifer System

\begin{tabular}{|l|l|l|l|l|l|}
\hline & \multicolumn{5}{|c|}{ Shallow aquifer system } \\
\hline Paramter & K Basalt & K Springs & K B45 & Sy Basalt & Sy B45 \\
\hline Calibrated value, m/day & 15 & 30 & 1.2 & 0.002 & 0.02 \\
\hline Composite Sensitivity & 0.07 & 0.04 & 0.14 & 0.04 & 0.18 \\
\hline
\end{tabular}




\section{Development of suitability maps for Managed Aquifer Recharge}

\subsection{Introduction}

As a result of increasing demand, aquifer systems have been exposed to a heavy abstraction that exceeds their natural replenishment. The variable and stormy pattern of rainfall cause low rate of groundwater recharge and higher rates of surface runoff; whereby excess water is lost when a water storage system is not available. Managed Aquifer Recharge (MAR) is considered as an effective tool for the sustainable management of groundwater resources in arid and semi-arid areas (Al-Assa'd, and Abdulla, 2010; Chenini and Ben Mammou, 2010).

MAR implementation has been reported in many studies with a special emphasis on the determination of areas most suitable for artificial recharge. A qualitative method is applied by the majority of studies using GIS techniques where thematic maps of variable types of factors are prepared and combined. Hydrogeological factors seem to be investigated to a limited extent, additionally variable criteria are applied for the definition of suitability ranges of the factors. Table 3.4 shows suitability ranges proposed by different authors for the factor "'depth to groundwater'.

Screening out unsuitable sites based on the depth to groundwater is critical to ensure the successful implementation of MAR. Sufficient depth to groundwater is needed in order to avoid the interference of groundwater mounding with the infiltration process. However, a very deep groundwater table will reduce the suitability of a site for MAR as reduced travel time through the vadose zone is favorable (Bouwer, 2002). A fixed criterion of choosing suitable ranges of depth to groundwater can't be drawn even within the same study area. The decision will be based on other factors (aquifer transmissivity, specific yield, volume and rate of infiltrated water...) which determines the response of the water table beneath the infiltration site. Therefore, a qualitative approach whereby factors are individually analyzed and where the characteristics of the water source for artificial recharge is not included can be associated with a lot of uncertainty.

A quantitative approach of mapping suitable sites for MAR based on the response of groundwater table underneath an infiltration basin can be associated with less 
uncertainty. The application of such quantitative approach in assigning suitable sites for MAR has been limited in the literature. Smith and Pollock (2012) applied the analytical solution of Glover (Glover 1961) in the simulation of groundwater mounding underneath an infiltration basin on a spatial scale across Perth Coastal Plain in Australia.

The application of analytical solutions, e.g. (Glover,1961; Hantush ,1967) is associated with some simplifying assumptions. These solutions assume a horizontal groundwater flow which neglects the impact of aquifer's vertical anisotropy. Additionally, the aquifer is assumed to be homogeneous resulting in errors whose magnitude depends on the degree of aquifers inhomogeneity.

\subsection{Definition of purpose}

In this chapter, a quantitative method will be applied to delineate suitable sites for Managed Aquifer Recharge based on sub-surface (hydrogeological) criteria. Numerical solutions (finite difference) will be used for the simulation of groundwater mounds beneath an infiltration basin, which reduces the simplifying assumptions associated with analytical solutions (assumptions of horizontal water table and a homogenous aquifer), and allows the inclusion of vertical hydraulic conductivity.

A new approach of applying numerical solutions in the spatial computation of groundwater mound height using a minimized number of model-runs will be adopted to overcome the limitation of applying numerical solutions on a spatial scale where considerable efforts and time are needed.

Following that, a qualitative approach is applied to create a suitability map for MAR based on basin's surface characteristics. A new GIS decision rule is introduced for the integration of factors which overcomes the limitation of variable factors and weights suggested in the literature.

The two suitability maps are combined to obtain final suitability map and propose based on which potential sites for MAR implementation. 


\subsection{Quantitative approach for creating MAR suitability map based on subsurface characteristics}

\subsubsection{Presentation of the method}

Numerical simulations of groundwater mounds underneath a hypothetical infiltration basin for different scenarios of infiltration water volumes will be conducted at a few locations across the study area. The results will be employed to calibrate an empirical equation that calculates the height of groundwater mound as a function of aquifer saturated thickness and volume of infiltrated water. The calibrated equation can then be applied in GIS to spatially evaluate the response of groundwater table to artificial recharge.

For the simulations, regional values of hydraulic conductivity and specific yield are used. In Addition, a uniform structure's design and infiltration rate are applied which leaves the saturated thickness as the only spatially variable factor in each aquifer. Simulations are conducted at different locations of each aquifer in order to draw a relationship between aquifer's saturated thickness and height of groundwater mound for a certain volume of infiltrated water. The uncertainty associated with using regional values of hydraulic properties is analyzed by conducting a sensitivity analysis.

\subsubsection{Groundwater flow model design}

The prepared groundwater flow model (chapter 5) is used as a base for conducting the simulations of groundwater table's response to artificial recharge. The models' top layer (representing the sallow aquifer complex) was vertically discretized into 3 layers to represent the impacts of vertical anisotropy on artificial recharge. Horizontal discretization was amended where cells size at the locations of hypothetical MAR structures was reduced. Simulations were conducted under transient state for a period of 15 days at a time-step of one day. Justification of the chosen period of 15 days is explained below. The distribution of heads simulated in the original model for the year 2012 was used as initial conditions for artificial recharge simulation. 


\subsubsection{Assumptions for the simulation of groundwater mounding}

Simulation of groundwater mound is a local model that requires site-specific information on aquifer's characteristics (saturated thickness, horizontal and vertical hydraulic conductivity, specific yield) and on the shape, capacity and operation conditions of the infiltration basin. Application of a local model to simulate groundwater response spatially across the aquifer requires some simplifying assumptions. In the following, the factors considered in the simulations and the associated assumptions are presented.

\subsubsection{Basin design}

the impacts of artificial recharge on the groundwater table could vary with the structure's design (size and shape) and operating conditions. The design of two recent MAR structures in the Azraq basin (Madoneh and Butum dams) (Steinel, 2012) is imitated. MAR structure will be simulated as a series of successive infiltration basins, each with a capacity of $0.25 \mathrm{MCM}$, and dimensions of $(200 * 200) \mathrm{m}$. The number of basins is a function of the collection capacity of the whole structure (amount of collected water).

\subsubsection{Water amount}

Preliminary analysis of the characteristics of infiltration water resource is important to select relevant scenarios and appropriate assumptions of artificial recharge. In the study area, storm water is the source of water. An initial design of MAR structure will be based on the amount and variability of storm water.

Analysis of runoff events in the years (1970-2012), calculated using the Curve Number method (Section 4.4), shows that average number of runoff events range between 1.2-1.7/month for the different wadis of the study area, therefore monthly values will be used for selecting relevant scenarios of water amount. Table 6.1 depicts the $50^{\text {th }}$ and $80^{\text {th }}$ percentile of monthly surface runoff for different wadis. The ability of sites to receive the $50^{\text {th }}$ and $80^{\text {th }}$ percentiles of monthly runoff in the respective wadi will be tested by conducting the simulations under eight representative scenarios of water volumes $(0.25,0.5,0.75,1,1.25,1.75,2.5,3.75)$ MCM. 
Table 6.1: 50th and 80th percentile of monthly surface runoff (MCM) in some wadis of the study area.

\begin{tabular}{|l|l|l|l|l|l|l|l|}
\hline & Rajil & U-H-R & Mudseisat & Hassan & Ghadaf & Aseikham & Jesha \\
\hline $50^{\text {th }}$ & 2.9 & 0.35 & 0.87 & 0.5 & 0.75 & 0.2 & 0.3 \\
\hline $80^{\text {th }}$ & 5.24 & 1.78 & 4.33 & 0.8 & 3.3 & 0.35 & 1.5 \\
\hline
\end{tabular}

\subsubsection{Simulation time}

For the same amount of water, the shorter the time of infiltration, the higher the mound. Time needed for collected water to infiltrate can be computed based on the infiltration rate of the top soil layer. Infiltration rates can be estimated roughly based on constant percentage of hydraulic conductivity, however, ratio of vertical saturated hydraulic conductivity $(\mathrm{Kv})$ to infiltration rate reported in the literature (e.g. Lee et al. 1992; Heisig and Prince 1993) can vary across several orders of magnitude (Smith and Pollock, 2012).

Infiltration tests from wadi butum in the Azraq basin gave an infiltration rate of $0.15-0.24 \mathrm{~m} / \mathrm{d}$ (Abu-Taleb, 1999). With such infiltration rate, the $0.25 \mathrm{MCM}$ water collected by a single basin assumed to have dimensions of $(200 * 200) \mathrm{m}$ would need 26-41 days to be drained (neglecting evaporation loses). For desert dams, it is preferred to enhance the infiltration rate using trenches/wells to achieve a smaller residence time which would minimize the evaporation loses. In this study, an enhanced uniform infiltration rate is assumed across the study area with a constant infiltration time of 15 days.

\subsubsection{Transmissivity $(\mathrm{T})$}

Transmissivity $\left(\mathrm{L}^{2} / \mathrm{T}\right)$ is defined as the horizontal hydraulic conductivity $(\mathrm{K})$ multiplied by aquifer's saturated thickness. This factor influences the rate at which water is transmitted away from the infiltration point.

The calibrated values of hydraulic conductivity for each formation of the shallow aquifer system (Basalt and the B4/5), see Table 5.1, are applied for the simulation. However, the application of $\mathrm{K}$ values calibrated at the aquifer scale can't accurately explain hydraulic patterns at a local-scale. The hydraulic properties of the B4/5 aquifer vary with the degree of karstification and fractures. The Basalt Aquifer is characterized by variable transmissivity where permeability is enhanced 
along fault lines and preferential flow paths. In order to assess the impacts of inaccurate estimation of $\mathrm{K}$ on the height of groundwater mound a second scenario ( $\mathrm{K}$ equals $50 \%$ of calibrated value) is considered.

The distribution of saturated thickness of the aquifers can be considered as readily available data obtained with enough accuracy by subtracting the elevation of groundwater table from the elevation of the aquifer base. The distribution of heads simulated with the groundwater model in chapter 5 across the area for the year 2012 was used because an updated contour map of groundwater table doesn't exist.

Saturated thickness is greatly variable ranging between $20 \mathrm{~m}$ to more than $700 \mathrm{~m}$. Simulations were conducted at 8 locations in the basalt with saturated thickness of $(38,60,71,120,137,151,176,237)$ meters and at 10 locations in the B4/5 Aquifer with saturated thickness of $(28,48,106,190,220,267,339,422,475,543)$ meters. Based on these data points the trend between the height of groundwater mound and saturated thickness for each aquifer and for a certain scenario of infiltration water volume can be drawn to estimate groundwater mound height at other locations.

\subsubsection{Vertical hydraulic conductivity $(\mathrm{Kv})$}

The ratio of horizontal to vertical hydraulic conductivity of 10:1 is a common ratio that is going to be used for all the simulations in this study.

\subsubsection{Specific yield $(\mathrm{Sy})$}

Specific yield of the aquifer describes the amount of water that can be stored in the unsaturated zone for a certain raise of groundwater table. Calibrated values of Sy for each formation were used in the simulations. Additionally, a second scenario (50\% of calibrated Sy) was applied to show the sensitivity of results to this factor.

\subsubsection{Presentation of simulations results}

A total number of 192 simulations of groundwater mound height at 8 different sites in the Basalt Aquifer, and for 8 different scenarios of infiltration water volume will be conducted under 3 main scenarios (A1, A2, A3), and 240 simulations of groundwater mound height at 10 sites in the B4/5 Aquifer, and for 8 different scenarios of infiltration water volume will be conducted under 3 main scenarios (B1, B2, B3), Table 6.2 shows the description of the scenarios. 
For each scenario, the simulated height of groundwater mound will be plotted against the respective value of saturated thickness for the 8 scenarios of water volume. A comparison of the plots provides an idea on the sensitivity of results for hydraulic properties of aquifers.

Table 6.2: Description of main scenarios for the simulations of groundwater mound.

\begin{tabular}{|l|l|l|l|}
\hline & Horizontal K, m/day & Vertical K, m/day & Sy \\
\hline $\begin{array}{l}\text { Scenario } \\
\text { A1 }\end{array}$ & Calibrated value (15) & Calibrated value (1.5) & Calibrated value (0.002) \\
\hline $\begin{array}{l}\text { Scenario } \\
\text { A2 }\end{array}$ & $0.5^{*}$ Calibrated value (7.5) & $0.5^{*}$ Calibrated value $(0.75)$ & Calibrated value (0.002) \\
\hline $\begin{array}{l}\text { Scenario } \\
\text { A3 }\end{array}$ & Calibrated value (15) & Calibrated value (1.5) & $0.5^{*}$ Calibrated value (0.001) \\
\hline $\begin{array}{l}\text { Scenario } \\
\text { B1 }\end{array}$ & Calibrated value (1.2) & Calibrated value $(0.12)$ & Calibrated value (0.02) \\
\hline $\begin{array}{l}\text { Scenario } \\
\text { B2 }\end{array}$ & $0.5^{*}$ Calibrated value (0.6) & $0.5^{*}$ Calibrated value (0.06) & Calibrated value (0.02) \\
\hline $\begin{array}{l}\text { Scenario } \\
\text { B3 }\end{array}$ & Calibrated value (1.2) & Calibrated value $(0.12)$ & $0.5^{*}$ Calibrated value $(0.01)$ \\
\hline
\end{tabular}

Scenarios A1 and A2 can be combined by multiplying the 8 values of saturated thickness for which simulations were conducted by $\mathrm{K}$ values of these two scenarios $(15,7.5) \mathrm{m} /$ day. The resulting 16 values of aquifer transmissivity are plotted against their corresponding results of simulated groundwater mound height for each scenario of water volume. The resulting data points can be used to calibrate the empirical equation that computes groundwater mound height for the Basalt Aquifer by means of curve fitting.

Similarly, scenarios B1 and B2 are combined, and the resulting twenty values of aquifer transmissivity with their corresponding simulation results for each scenario of water volume can be used to calibrate the equation that computes groundwater mound height for the B4/5 Aquifer.

\subsubsection{Empirical equation for the calculation of groundwater mound's height}

For an aquifer of a constant value of $\mathrm{Sy}$ and $\mathrm{Kv}$, and for a fixed design and operation conditions of MAR structure, the height of groundwater mound is 
directly proportional to the volume of infiltrated water (W) [m3], and inversely proportional to aquifer transmissivity $\left[\mathrm{m}^{2} \cdot \mathrm{day}^{-1}\right]$, equation (6.1).

$$
\text { height of } G W M=f\left(\frac{W}{K * \text { Saturated thickness }}\right)+\varepsilon
$$

Where $\varepsilon$ is an error resulting from conducting the simulations at different locations of the aquifer characterized by variable conditions and aquifer geometry.

Regression coefficients are empirically introduced and calibrated for each aquifer using method of curve fitting through data points of simulation results for the scenarios aforementioned. The regression coefficients are estimated using the Generalized Reduced Gradient algorithm, (Abadie and carperntier, 1969).

\subsubsection{Application of derived equations in the generation of MAR suitability map}

A suitability map for MAR implementation in the basin will be generated based on subsurface characteristics first using derived and calibrated equations.

The purpose of MAR is to reduce groundwater decline in the basin especially in discharge areas where the most drastic decline occurs. Therefore, MAR structures are favorably implemented close to the center of the basin where the majority of wells (domestic and irrigation) take place. Fig. 6.1 shows the area that will be investigated for MAR implementation.

Derived equations are applied spatially to prepare a raster of groundwater mound height for 2 scenarios of MAR structure's collection capacity (based on the 50th and 80th percentile of monthly runoff in the respective wadi), and 2 scenarios of hydraulic conductivity (calibrated and $50 \%$ of calibrated values) using the raster algebra tool in ArcGIS.

A raster of the distribution of saturated thickness of the shallow aquifer system (Fig. 6.2), a raster of the 50th and 80th percentile of monthly runoff in the different wadis of the area, and a raster of calibrated $\mathrm{K}$ and $50 \%$ calibrated $\mathrm{K}$ of the formations (Basalt and B45) in the area will be the input for calculation. 
Additionally, a raster of the distribution of depth to groundwater table will be prepared by subtracting a USGS Digital Elevation Model from the simulated distribution of heads for the year 2012 (Fig. 6.3). All maps have a resolution of $(30 * 30) \mathrm{m}$. suitability map is generated from subtracting the raster of 'groundwater mound height' from the raster of 'depth to groundwater'. Negative values on this map delineate unsuitable sites for MAR.

After removing unsuitable sites, uniform criteria could be applied to rank suitable locations as very suitable, suitable, and less suitable. The smaller the depth to groundwater the more suitable the site is (Table 6.3).

Table 6.3: Suitability criteria for the factor 'depth to groundwater'

\begin{tabular}{|l|l|}
\hline Suitability class & Range of depth to groundwater values, $\mathbf{m}$ \\
\hline $0-20$ & Very suitable \\
\hline $20-50$ & suitable \\
\hline $50-80$ & Less suitable \\
\hline $80<$ & Not suitable \\
\hline
\end{tabular}

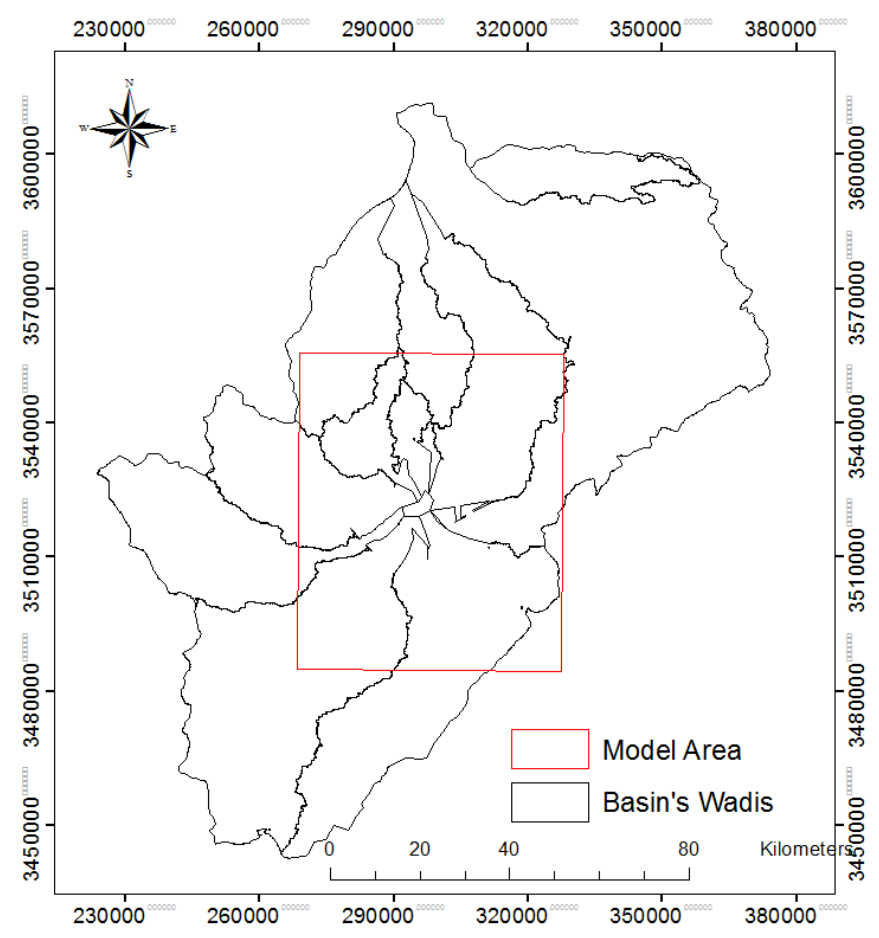

Fig. 6.1: GIS model's domain, investigated area for MAR 


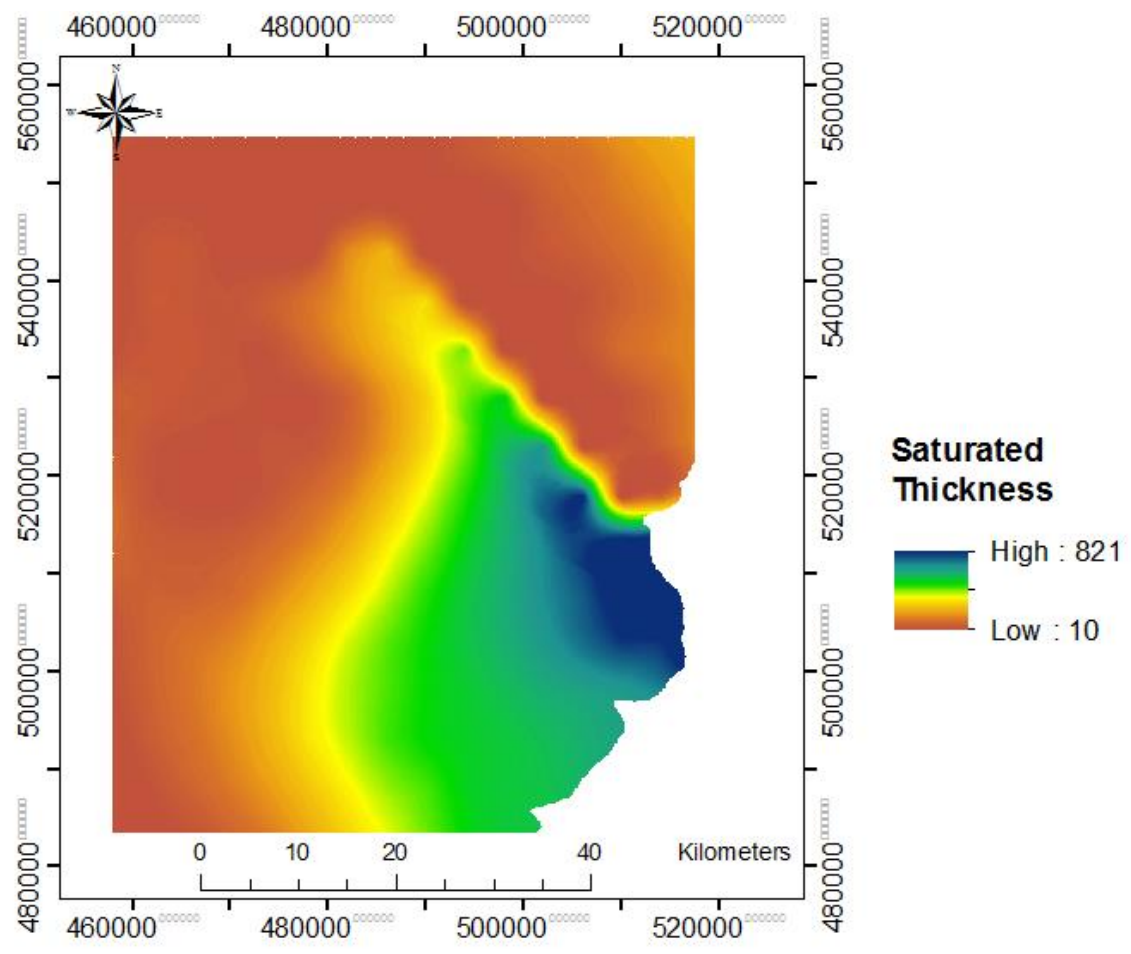

Fig. 6.2: Aquifer' saturated thickness in the investigated area

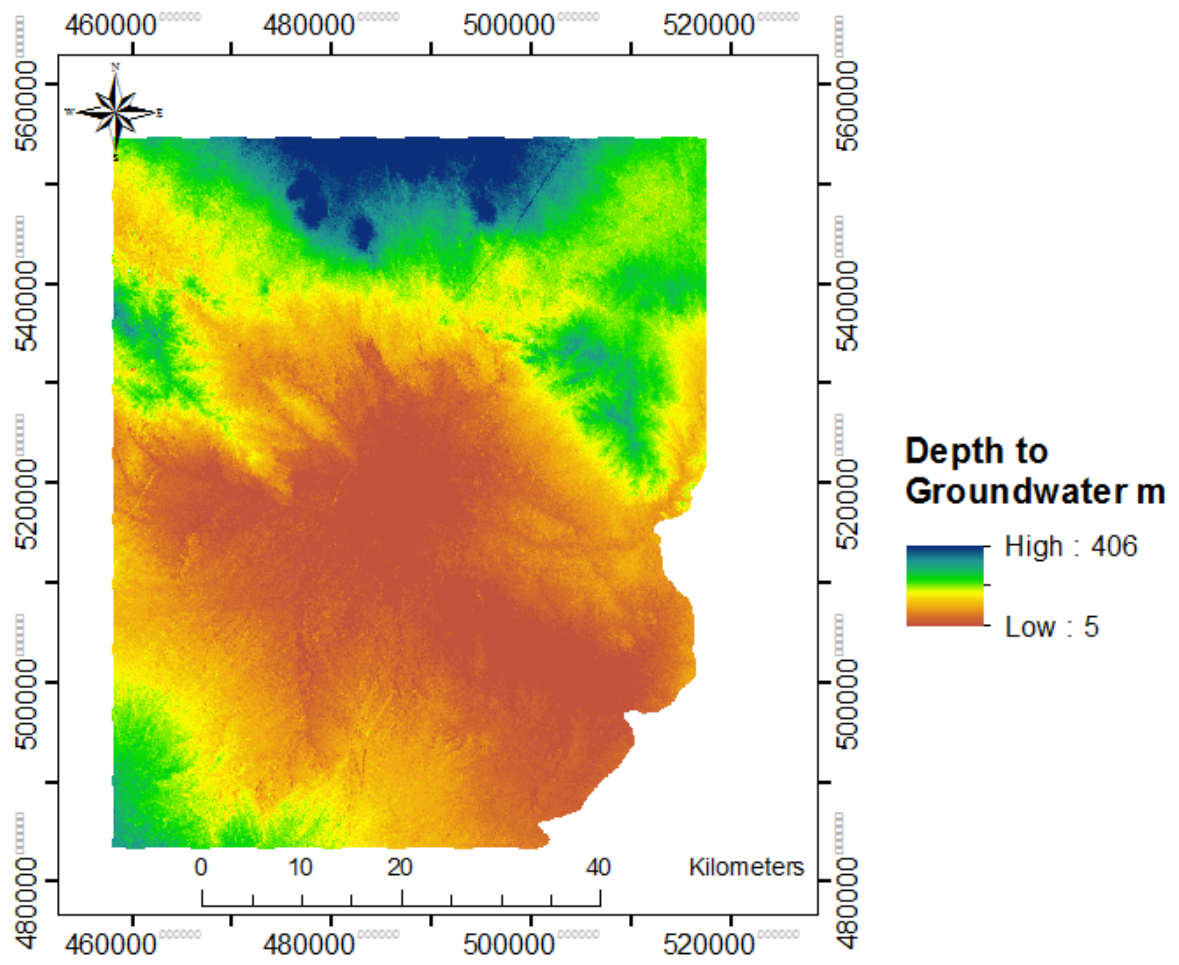

Fig. 6.3: Depth to groundwater in the investigated area 


\subsection{Qualitative approach for creating MAR suitability map based on surface characteristics}

\subsubsection{Presentation of a new approach of integrating thematic layers}

There are different decision rules in GIS that are used for integrating and analyzing thematic layers. Weighted Linear Combination (WLC) method has been widely applied in many researches (Shatnawi, 2006; Al-Adamat, et al., 2010 ; Yalcin, 2008). It involves classifying each factor map to classes and assigning a score to each class depending on its suitability to locate rainwater harvesting structures/MAR. A weight is assigned for each factor layer which represents its comparative importance. The scores of each map at each location are combined to obtain a final map whereby an overall suitability score is identified at each location. The exact set of characteristics associated with each final suitability score obtained using WLC is not identified.

In this study, a decision system is proposed where a suitability degree is assigned to a set of characteristics, so that the suitability of each class of each factor is judged in combination with other factors' classes.

Assume we have $\mathrm{n}$ factors each consisting of $\mathrm{m} 1, \mathrm{~m} 2$.. $\mathrm{mn}$ number of classes. Based on the counting principle the total number of results (sets of characteristics) we obtain when we combine the factors is:

$$
S=m 1^{*} m 2^{*} m 3 \ldots{ }^{*} m n
$$

The method is based on giving each class of each factor a certain score so that when the factors are combined, each of the $\mathrm{S}$ number of sets of characteristics has a distinctive final score.

In order to assign the scores, each degree of suitability for each factor will be assigned a number $(0,1,2 \ldots)$ where 0 is assigned to "unsuitable" classes, and then each factor is multiplied by a weight. The weight is calculated based on the number of possible sets that can be obtained when eliminating that factor along with previous factors. The weight of the first factor is the number of all possible sets of characteristics that we obtain when combing all factors except for the first factor $(\mathrm{m} 2 * \mathrm{~m} 3 \ldots * \mathrm{mn})$. The weight of the second factor is the number of all 
possible sets of characteristics we obtain when combing all factors except for the first and second factors $(\mathrm{m} 3 * \mathrm{~m} 4 \ldots * \mathrm{mn})$. The weight of the last factor is one.

\subsubsection{Thematic maps of surface characteristics}

In this study, three surface factors are investigated in the basin for their suitability for MAR implementation; slope, soil texture and soil thickness, to generate a MAR suitability map in terms of surface factors.

\subsubsection{Slope}

A map of slope of the area was prepared based on USGS-DEM (Section 4.2.3). Infiltration rate is reduced when surface slope exceeds $5 \%$ (Saraf and Choudhury, 1998). Slope values are classified based on their suitability to locate MAR into three categories: (0-5\% suitable, 5-10\% Less Suitable, >10 Unsuitable).

\subsubsection{Soil texture}

Soil texture in Azraq is described as a clayey to loamy texture and often contain a high percentage of gravels, stones and boulders. Clay content depend largely on the erodibility, slope steepness and curvature of the upslope parent material (Ziadat et al., 2010). A map of superficial deposits in the basin prepared after Steinel (2012) is shown in Fig. 6.4. Saturated hydraulic conductivity of the soil can be can be estimated based on the distribution of grain-size, organic matter, bulk density and other parameters using a number of functions. e.g Cosby et al. (1984). Detailed investigation and soil profiles testing are needed which are not available in the area. In this study, the suitability of soil texture for MAR will be based on the content of fine sediments, where silt and clay are considered unsuitable, loam is less suitable, and sand is suitable. It should be noted that infiltration test is still necessary to evaluate the final suitability of a site for MAR. During infiltration, the wetting front moves down according to local-scale heterogeneity (Warburton, 1998) which can’t be reflected by grain-size distribution analysis, and can vary greatly for the same soil texture (Steinel, 2012).

\subsubsection{Soil thickness}

Thickness of soils in the study area depend largely on the erodibility and slope steepness. The Qaa deposits can be up to $5 \mathrm{~m}$ thick (Borgstedt et al., 2007). A map 
of soil thickness classified into three classes was prepared after (Steinel, 2012 ), see Fig. 6.5. A thin soil layer is preferred for the implementation of MAR. soil thickness greater than $80 \mathrm{~cm}$ are considered unsuitable.

\subsubsection{Application of the decision system in the Generation of MAR suitability map}

In this study, the new decision system will be applied to create a MAR suitability map in terms of surface characteristics. The three factors (slope, soil texture, and soil thickness) will be analyzed. Each of these factors has 3 classes of suitability, thus the number of all possible sets of characteristics is: $3 * 3 * 3=27$.

Thematic maps of these factors are prepared, and classified based on their suitability for MAR implementation. Suitability degrees for each factor are explained above and summarized in Table 6.4. For each thematic layer, the scores 2, 1, 0 are assigned to the suitability degrees (suitable, less suitable, unsuitable) respectively, see Fig. 6.6, Fig. 6.7 and Fig. 6.8.

Table 6.4: Suitability classes and scores of surface factors

\begin{tabular}{|l|l|l|l|l|}
\hline Suitability degree & Score & Slope \% & Soil Texture & Soil Thickness cm \\
\hline Suitable & 2 & $0-5 \%$ & sand & $50>$ \\
\hline Less Suitable & 1 & $5-10 \%$ & loam & $50-80$ \\
\hline Not Suitable & 0 & $>10 \%$ & silt and caly & $80<$ \\
\hline
\end{tabular}

The weight for the first thematic map (e.g. slope) is the number of possible sets of characteristics when combing all factors except for slope; $3 * 3=9$. The weight for the second thematic map (e.g. Soil Texture) is the number of results when combing all factors except for slope and Texture; 3. And the weight for the last factor (Soil Thickness) is one. By applying these weights and combining the three weighted thematic layers we obtain a map with scores ranging from 0 till 26, whereby each of the 27 sets of characteristics is represented by a distinctive score. Each set of characteristics can then be individually judged, and assigned a new score based on its suitability, see Table 6.5. Even though each factor was divided into 3 degrees of suitability, any preferred number of suitability degrees can be chosen here. In this study, we use 4 suitability degree from 0 to 3 where 0 is unsuitable and 3 is very suitable. 


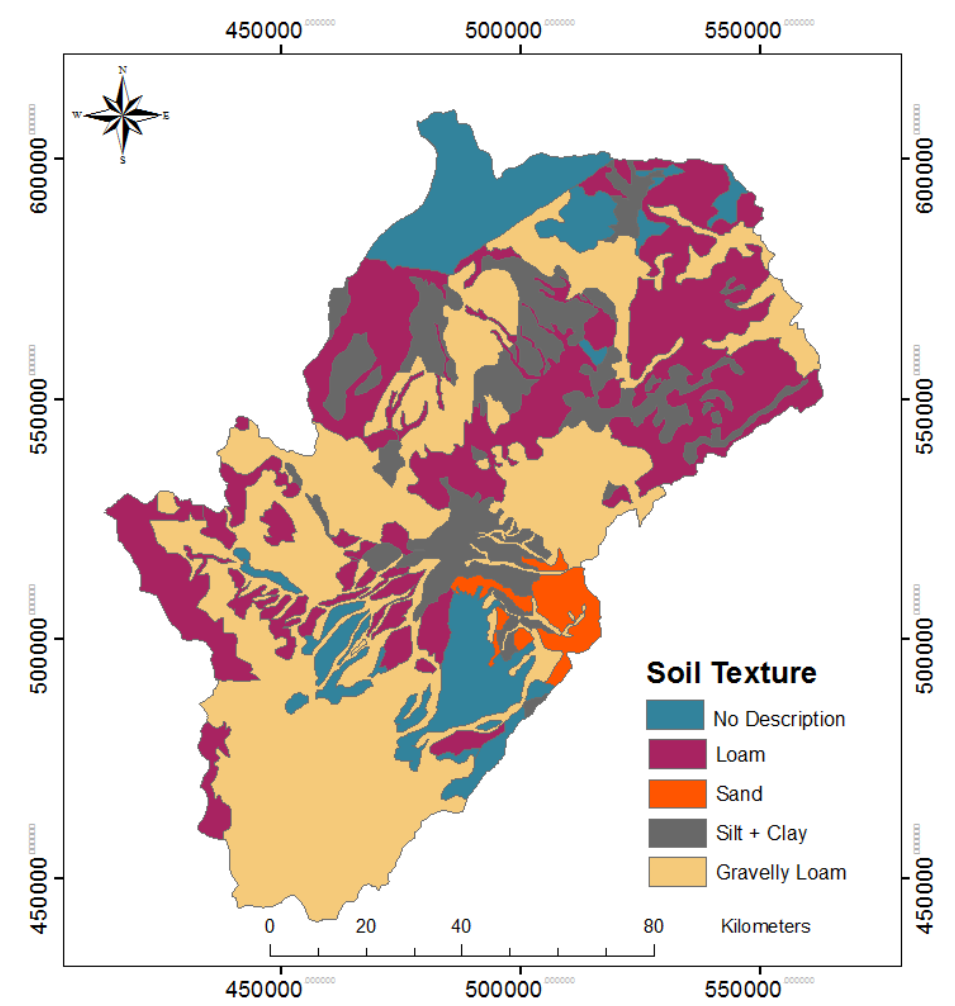

Fig. 6.4: Soil Texture in Azraq basin prepared after (Steinl, 2012)

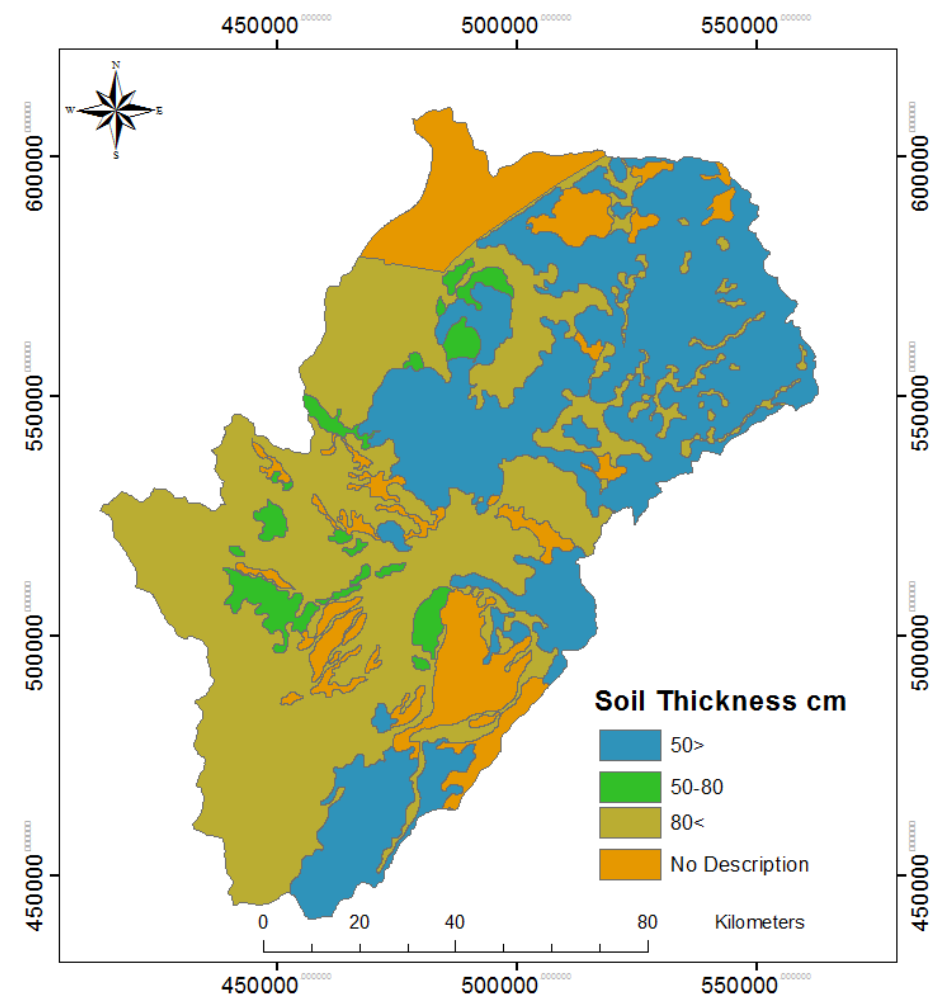

Fig. 6.5: Soil Thickness in Azraq basin prepared after (Steinl, 2012) 


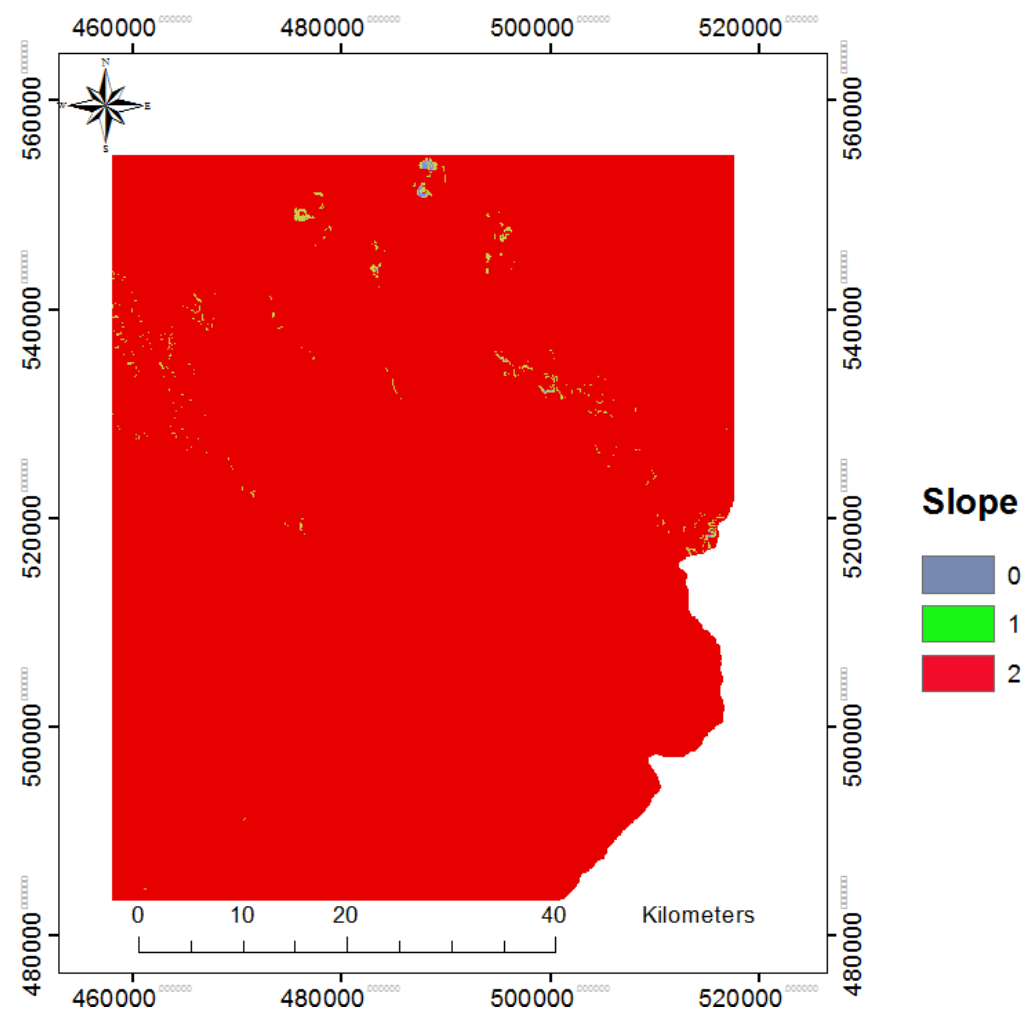

Fig. 6.6: MAR suitability map based on slope in the investigated area

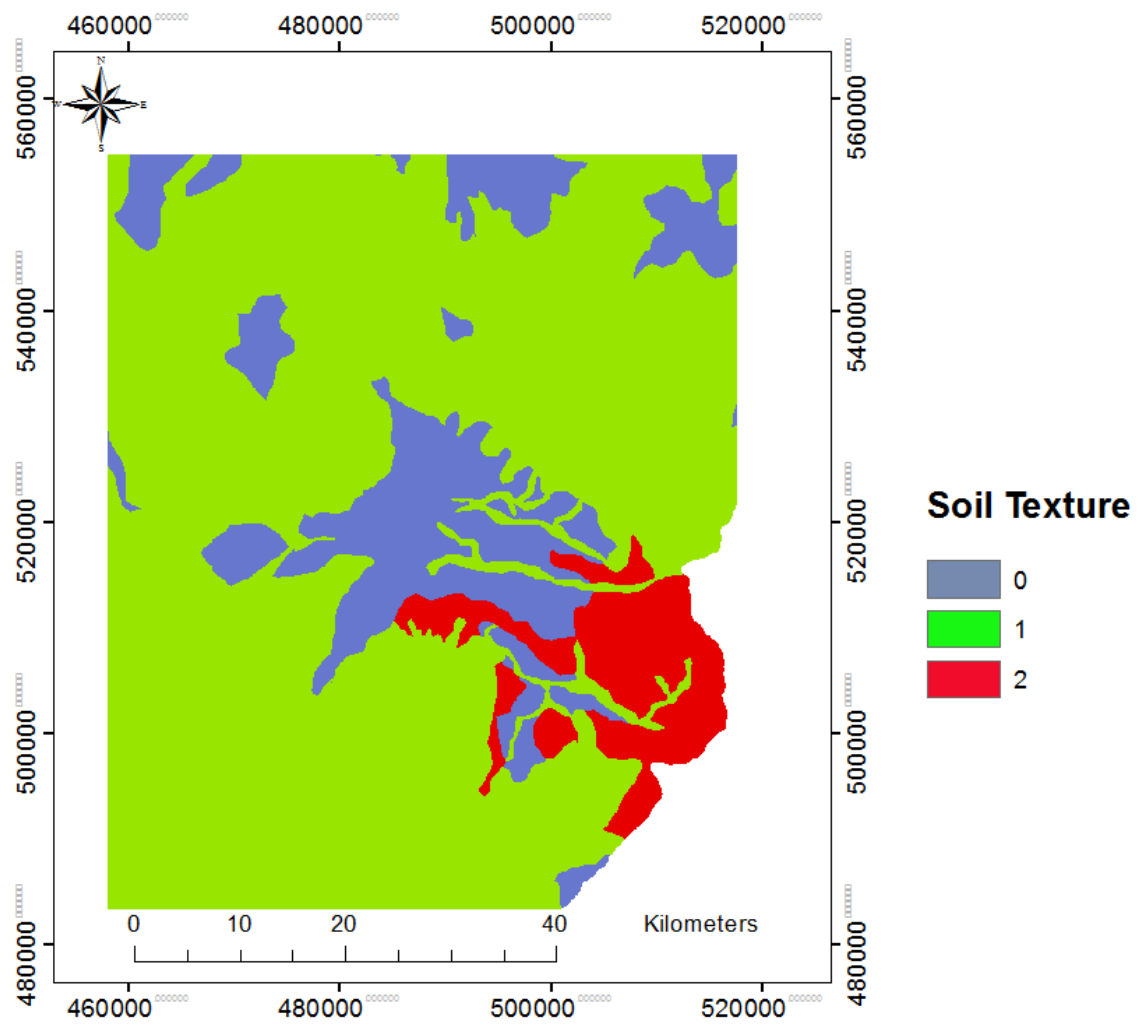

Fig. 6.7: MAR suitability map based on soil texture in the investigated area 


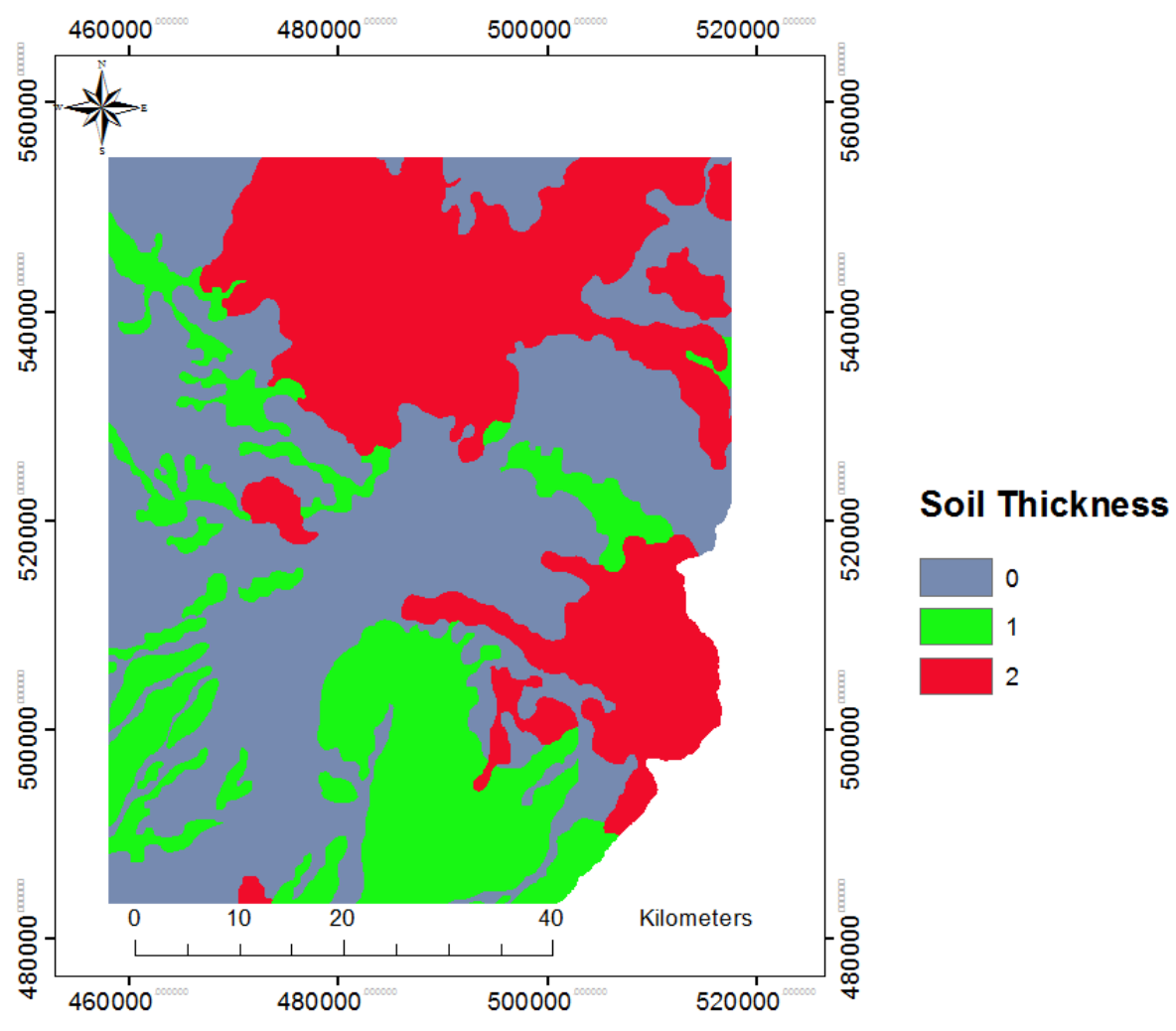

Fig. 6.8: MAR suitability map based on soil thickness in the investigated area

Unsuitable sites are those sites where slope is bigger than 10 regardless of the soil texture and thickness at that site, or where soil texture is clay and the thickness of soil is $50-80 \mathrm{~cm}$ or bigger than $80 \mathrm{~cm}$. Sites that can be amended to become more suitable will be deemed as less suitable, e.g. If the texture is clay, while the thickness is small $50 \mathrm{~cm}>$, the site can be deemed as less suitable because the top soil layer can be removed. Following this logic, each set of characteristics receives its own degree of suitability. By reclassifying the map through the application of 'classify by table' function in GIS using the last two columns of Table 6.5 MAR suitability map based on surface characteristics is obtained.

\subsection{Final suitability map}

Suitability maps in terms of surface and subsurface factors will be combined to obtain the final suitability map for MAR implementation. Each map is considered as a factor, each with 4 classes of suitability. The same decision system followed for the generation of suitability MAR in terms of surface characteristics will be applied here. 
Table 6.5: Suitability classes, given weights and final suitability of surface factors

\begin{tabular}{|c|c|c|c|c|c|c|c|}
\hline $\begin{array}{l}\text { Slope } \\
\text { suitability } \\
\text { score }\end{array}$ & $\begin{array}{l}\text { score*weight } \\
\text { (9) }\end{array}$ & \begin{tabular}{|l|} 
Texture \\
suitability \\
scores \\
\end{tabular} & $\begin{array}{c}\text { score*weight } \\
\text { (3) }\end{array}$ & $\begin{array}{l}\text { Thickness } \\
\text { suitability } \\
\text { scores }\end{array}$ & $\begin{array}{l}\text { score*weight } \\
\text { (1) }\end{array}$ & $\begin{array}{l}\text { Final } \\
\text { score }\end{array}$ & $\begin{array}{l}\text { Final } \\
\text { suitability } \\
\text { degree }\end{array}$ \\
\hline 2 & 18 & 2 & 6 & 2 & 2 & 26 & 3 \\
\hline 2 & 18 & 2 & 6 & 1 & 1 & 25 & 3 \\
\hline 2 & 18 & 2 & 6 & 0 & 0 & 24 & 3 \\
\hline 2 & 18 & 1 & 3 & 2 & 2 & 23 & 3 \\
\hline 2 & 18 & 1 & 3 & 1 & 1 & 22 & 3 \\
\hline 2 & 18 & 1 & 3 & 0 & 0 & 21 & 2 \\
\hline 2 & 18 & 0 & 0 & 2 & 2 & 20 & 1 \\
\hline 2 & 18 & 0 & 0 & 1 & 1 & 19 & 0 \\
\hline 2 & 18 & 0 & 0 & 0 & 0 & 18 & 0 \\
\hline 1 & 9 & 2 & 6 & 2 & 2 & 17 & 2 \\
\hline 1 & 9 & 2 & 6 & 1 & 1 & 16 & 2 \\
\hline 1 & 9 & 2 & 6 & 0 & 0 & 15 & 2 \\
\hline 1 & 9 & 1 & 3 & 2 & 2 & 14 & 2 \\
\hline 1 & 9 & 1 & 3 & 1 & 1 & 13 & 1 \\
\hline 1 & 9 & 1 & 3 & 0 & 0 & 12 & 1 \\
\hline 1 & 9 & 0 & 0 & 2 & 2 & 11 & 1 \\
\hline 1 & 9 & 0 & 0 & 1 & 1 & 10 & 0 \\
\hline 1 & 9 & 0 & 0 & 0 & 0 & 9 & 0 \\
\hline 0 & 0 & 2 & 6 & 2 & 2 & 8 & 0 \\
\hline 0 & 0 & 2 & 6 & 1 & 1 & 7 & 0 \\
\hline 0 & 0 & 2 & 6 & 0 & 0 & 6 & 0 \\
\hline 0 & 0 & 1 & 3 & 2 & 2 & 5 & 0 \\
\hline 0 & 0 & \begin{tabular}{|l|}
1 \\
\end{tabular} & 3 & 1 & 1 & 4 & 0 \\
\hline 0 & 0 & 1 & 3 & 0 & 0 & 3 & 0 \\
\hline 0 & 0 & 0 & 0 & 2 & 2 & 2 & 0 \\
\hline 0 & 0 & 0 & 0 & 1 & 1 & 1 & 0 \\
\hline 0 & 0 & 0 & 0 & 0 & 0 & 0 & 0 \\
\hline
\end{tabular}

Table 6.6 shows the given weights, the results of combination, and the final suitability degrees of each combination of surface and subsurface characteristics.

When Suitability in terms of subsurface characteristics is 0 , the final suitability is 0 independent of how suitable the site is in terms of surface factors. When the site is less suitable in terms of subsurface characteristics, the final suitability is 1 (less 
suitable) independent of how suitable the site is in terms of surface factors. When the site is suitable in terms of subsurface characteristics, but not suitable in terms of surface characteristics, the final suitability is also 1 (less suitable).

Table 6.6: Suitability classes, given weights and final suitability of surface and subsurface factors

\begin{tabular}{|l|l|l|l|l|l|}
\hline $\begin{array}{c}\text { Subsurface } \\
\text { suitability scores }\end{array}$ & $\begin{array}{c}\text { Score*weight } \\
(\mathbf{4})\end{array}$ & $\begin{array}{c}\text { Surface } \\
\text { suitability degrees }\end{array}$ & $\begin{array}{c}\text { degree*weight } \\
(\mathbf{1})\end{array}$ & $\begin{array}{c}\text { Final } \\
\text { score }\end{array}$ & $\begin{array}{c}\text { Final } \\
\text { suitability } \\
\text { degree }\end{array}$ \\
\hline 0 & 0 & 0 & 0 & 0 & 0 \\
\hline 0 & 0 & 1 & 1 & 1 & 0 \\
\hline 0 & 0 & 2 & 2 & 2 & 0 \\
\hline 0 & 0 & 3 & 3 & 3 & 0 \\
\hline 1 & 4 & 0 & 0 & 4 & 0 \\
\hline 1 & 4 & 1 & 1 & 5 & 1 \\
\hline 1 & 4 & 2 & 2 & 6 & 1 \\
\hline 1 & 4 & 3 & 3 & 7 & 1 \\
\hline 2 & 8 & 0 & 0 & 8 & 1 \\
\hline 2 & 8 & 1 & 1 & 9 & 2 \\
\hline 2 & 8 & 2 & 2 & 10 & 2 \\
\hline 2 & 8 & 3 & 3 & 11 & 2 \\
\hline 3 & 12 & 0 & 0 & 12 & 1 \\
\hline 3 & 12 & 1 & 1 & 13 & 3 \\
\hline 3 & 12 & 2 & 2 & 14 & 3 \\
\hline 3 & 12 & 3 & 3 & 15 & 3 \\
\hline
\end{tabular}

\subsection{Results and discussion}

Simulation results of groundwater mound heights are applied to derive an empirical equation that calculates groundwater mound underneath a hypothetical infiltration basin. The equation was calibrated for the Basalt and B45 aquifers separately. Derived equations are applied for the spatial simulation of groundwater mound height and preparation of MAR suitability map based on subsurface characteristics. This map is combined with a map of MAR suitability based on surface characteristics to obtain final suitability map. Based on final suitability map three MAR structures are suggested in the basin. 


\subsubsection{Calibrated equation for the simulation of Groundwater mound height}

The empirical equation that computes the height of groundwater mound (GWM) as a function of the volume of infiltration water and aquifer transmissivity reads as follow:

$$
\text { height of } G W M=\frac{\alpha+W}{\beta} * \frac{1}{T+\delta}+e
$$

Where:

$\mathrm{W}$ is volume of infiltrated water $\left[\mathrm{m}^{3}\right]$

$\mathrm{T}$ is aquifer' transmissivity [ $\mathrm{m}^{2}$.day-1].

$\alpha, \beta$ and $\delta$ are regression coefficients which are calibrated for each formation

$\mathrm{e}$ is the residual, which reflects the goodness of fit. The magnitude of $\mathrm{e}$ is influenced by $\varepsilon$ from equation (6.1).

Coefficient values reflects the characteristics of aquifers (Sy, Kv), shape and design of the infiltration basin and infiltration time.

\subsubsection{Simulation results}

\subsubsection{Basalt aquifer}

Fig. 6.9 shows simulation results for scenarios A1 A2 and A3. Fig. 6.9b shows that the height of groundwater mound has increased between $30 \%$ and $50 \%$ as a result of reducing horizontal and vertical hydraulic conductivity by $50 \%$. For smaller volumes of infiltrated water and higher values of saturated thickness the results show more sensitive to the decrease in $\mathrm{K}$.

Figure 6.9c shows that as a result of 50\% decrease in Sy value, the changes in groundwater mound height range between 1-7 \%. For higher volumes of infiltrated water and smaller values of saturated thickness results show more sensitivity to the decrease in Sy. Simulation results of scenarios (A1 and A2) used to calibrate equation (6.3) are depicted in Fig. 6.10 and Fig 6.11. One set of coefficients is derived for water scenarios 1 to $4(0.25,0.5,0.75,1) \mathrm{MCM}$ (equation 6.4), and another set was needed to fit the data for water scenarios 5 to $8(1.25,1.75,2.5$, 3.75) MCM (equation 6.5). 


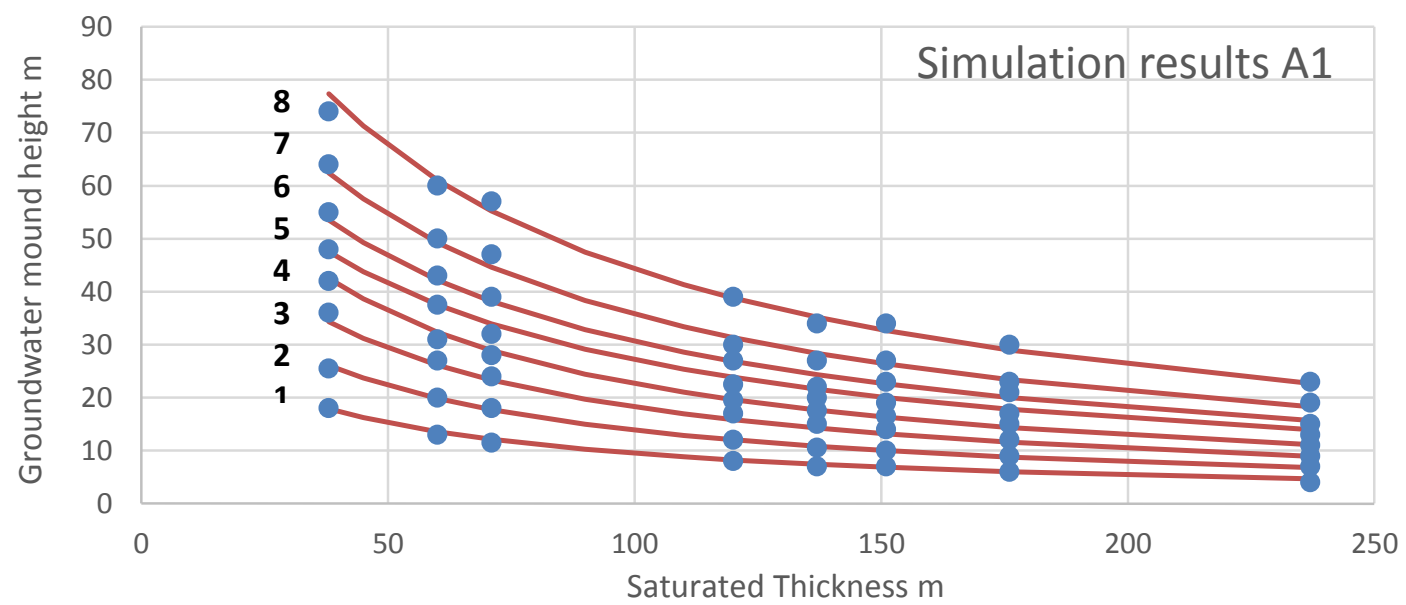

(a)

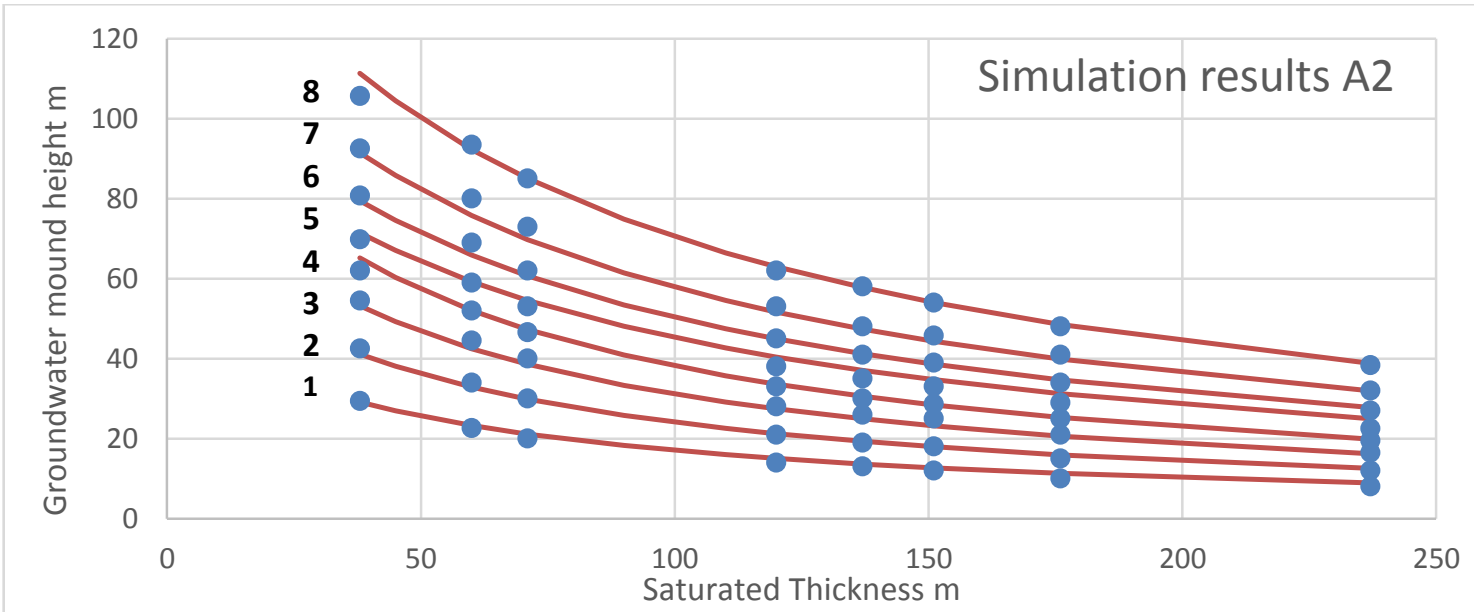

(b)

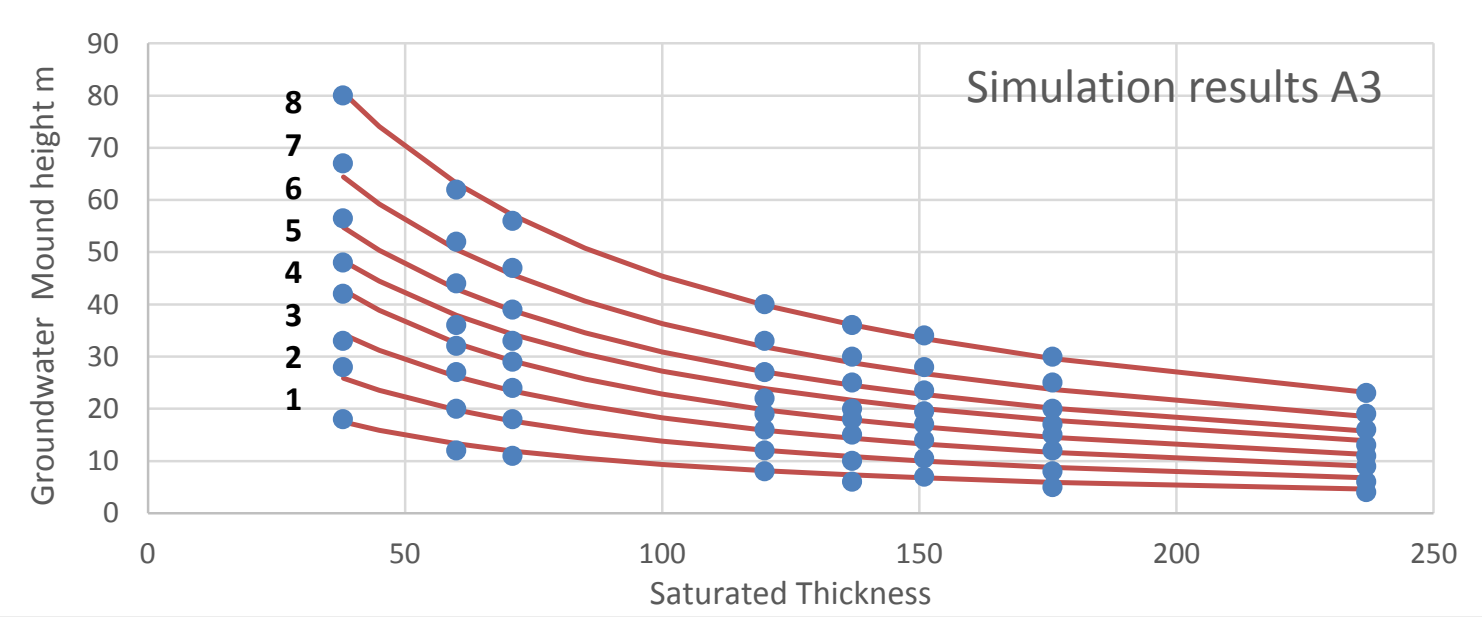

(c)

Fig. 6.9: Simulated groundwater mound for 8 scenarios of water volumes. a: schenaio A1, b: scenario A2, c: scenario A3. 


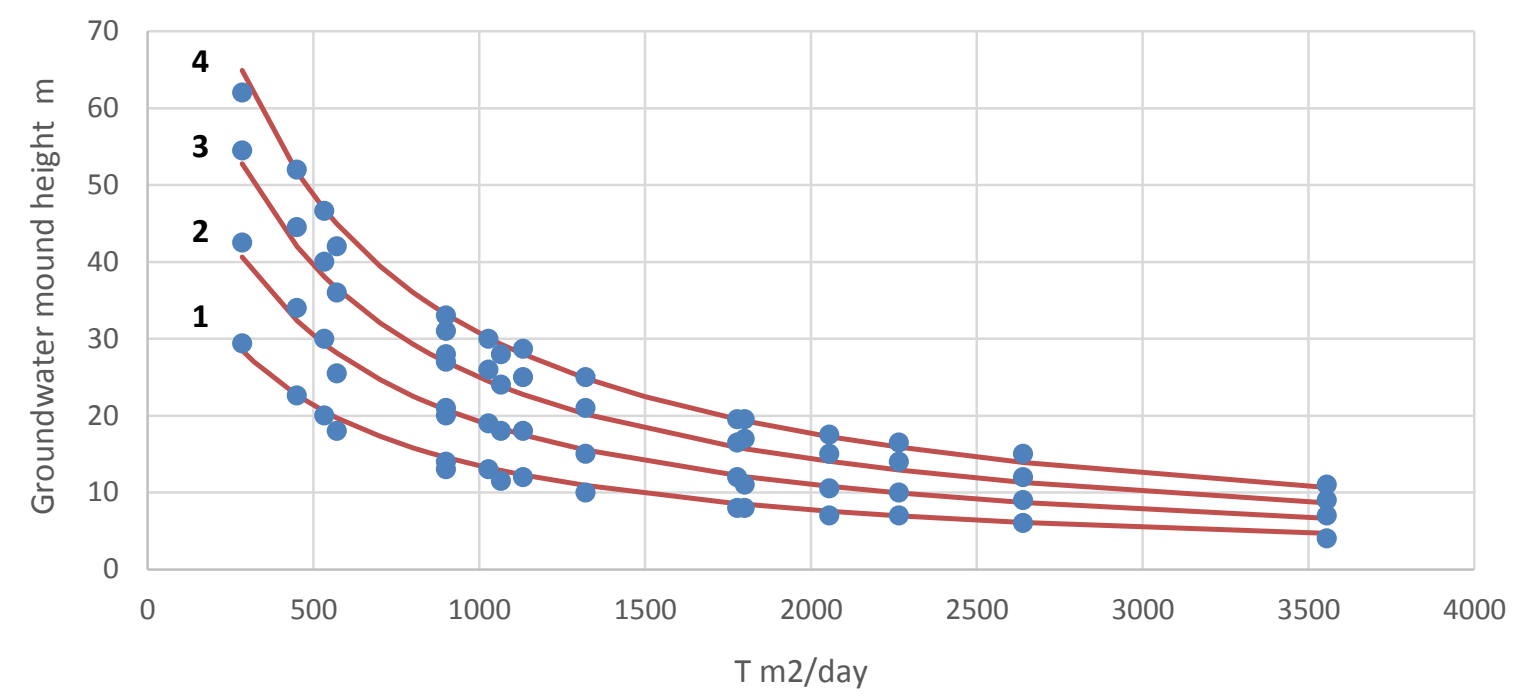

Fig. 6.10: Simulated groundwater mound height against $T$ values of Basalt aquifer, water scenarios $(1,2,3,4)$

$$
\text { GWM height }=\frac{0.33 * 10^{6}+\text { Water Volume }}{32} * \frac{1}{357+T}, e(-2,+3)
$$

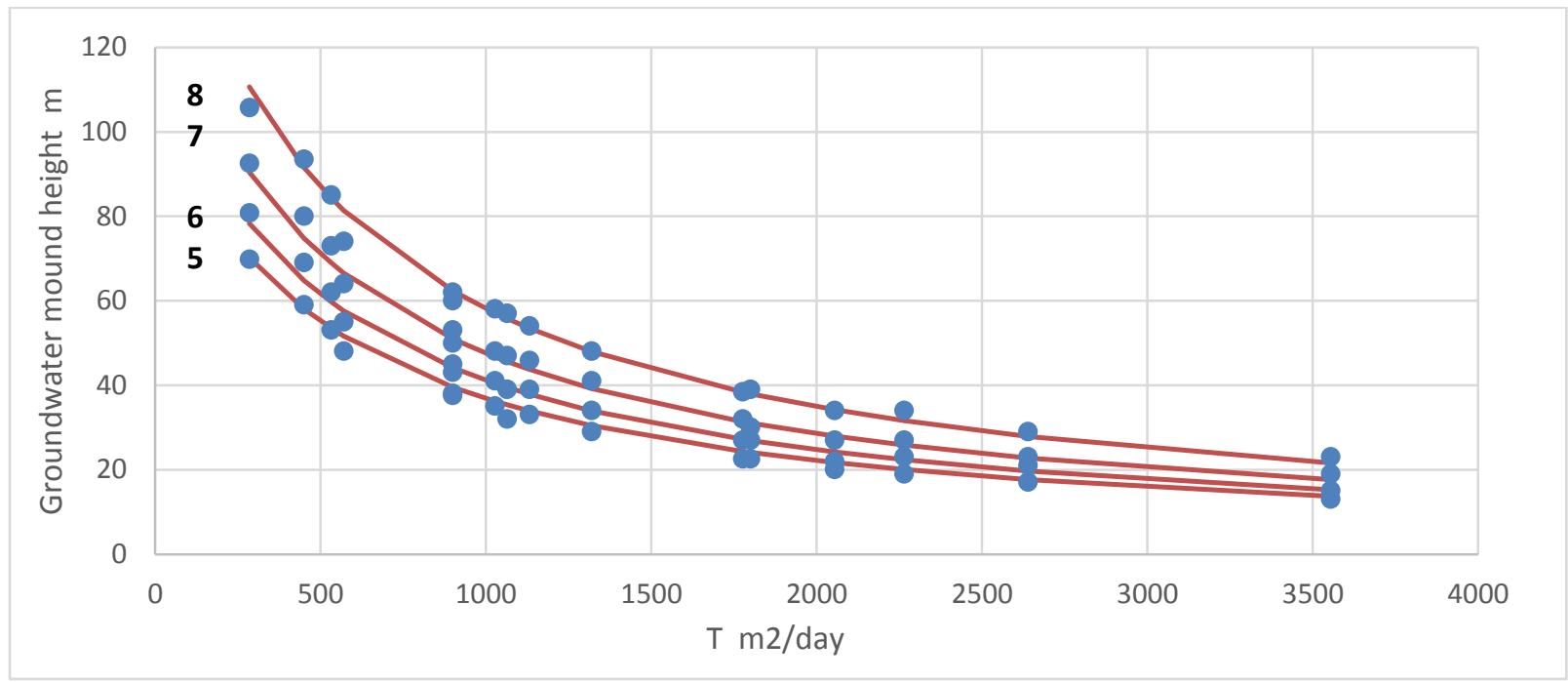

Fig. 6.11: Simulated groundwater mound height against $T$ values of Basalt aquifer, water scenarios $(5,6,7,8)$

$$
\text { GWM height }=\frac{3.1 * 10^{6}+\text { Water Volume }}{78} * \frac{1}{507+T}, e(-5,+7)
$$


Using the derived equations, groundwater mound height can be calculated based on values of aquifer transmissivity and water volume. Ranges of expected errors (e) are displayed next to each equation. The range of residuals for the basalt is small indicating a high certainty in the application of the derived equation.

Equations (6.4) and (6.5) are true for values of vertical $\mathrm{K}$ ranging between (1.5 $0.75) \mathrm{m} /$ day and specific yield of 0.001 .

Two sets of equations were needed one for water volume less than $1 \mathrm{MCM}$, and one for the other scenarios (water volume between 1 and $3.75 \mathrm{MCM}$ ). This can be attributed to the design and shape of MAR structure assumed to be composed of sequential basins. For higher water volume, the number of sequential basins is higher and infiltrated water spreads over a larger area of the aquifer than it would if a one single square basin was assumed for all scenarios of water volume. Therefore, the higher the volume of infiltrated water, the less the increasing rate of groundwater mound height.

\subsubsection{B45 aquifer}

Simulation results for the B4/5 Aquifer show that groundwater mound height has increased between $40 \%$ and $70 \%$ as a result of reducing horizontal and vertical hydraulic conductivity by $50 \%$. Additionally, as a result of $50 \%$ decrease in Sy value, the changes in groundwater mound height ranges between 1-12\%.

Similar to the Basalt Aquifer, equation (6.3) was calibrated using simulation results from scenarios (B1 and B2) depicted in Fig. 6.12 (scenarios of water volumes 5,6 and 7 are not shown for a better display of results).

Simulation results for T smaller than 60 couldn't be fit with the same equation as the rest of the points, and two sets of coefficients were needed to better describe the relationship for two ranges of transmissivity.

Equation (6.6) and (6.7) can be used to calculate groundwater mound height for water scenarios ( 1 to 4 ) and (5 to 8) respectively. Ranges of expected errors (e) are displayed next to each equation. The equations are true for values of vertical $\mathrm{K}$ ranging between $(0.12-0.06) \mathrm{m} /$ day and specific yield of 0.01 . The range of residuals for the B4/5 Aquifer was realized to be higher than that of the Basalt, which has a higher Transmissivity. This shows that for lower values of aquifer's 
transmissivity, the results are more sensitive to factors related aquifer's inhomogeneity, or variability in vertical K. Accurate estimation of groundwater mound height at sites of small $\mathrm{T}$ is not of importance. From Fig. 6.12, at $\mathrm{T}$ smaller than $60 \mathrm{~m}$ the water table is expected to rise for more than $100 \mathrm{~m}$ for all scenarios of water volume, and therefore these sites will be anyway screened out as unsuitable.

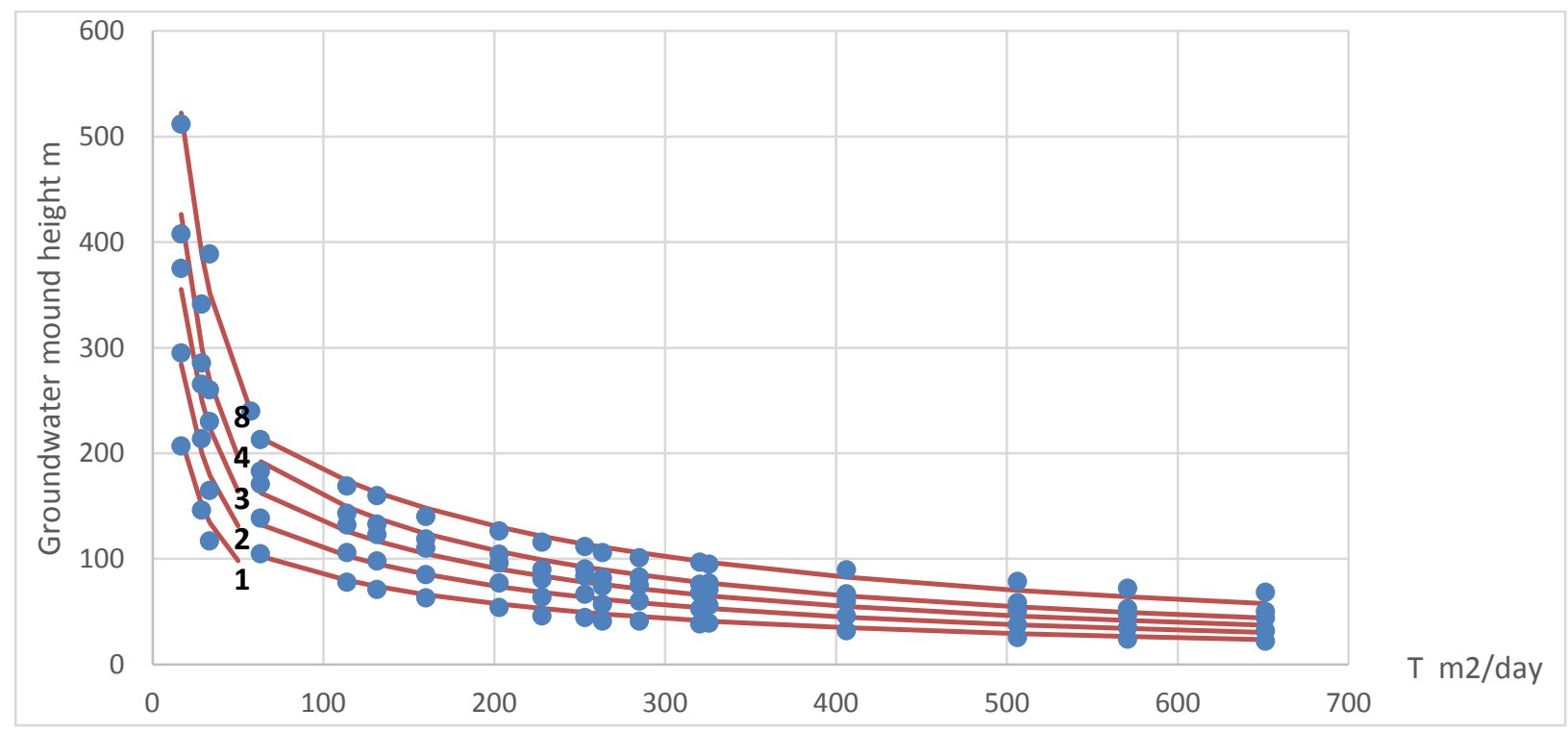

Fig. 6.12: Simulated groundwater mound height against $T$ values of the $B 45$ aquifer, water scenarios $(1,2,3,4,8)$

GWM height $=\left\{\begin{array}{l}\frac{0.5 * 10^{6}+\text { Water } V}{124.2} * \frac{1}{11.6+T}, \text { S.th }<60, e(-19,+18) \\ \frac{0.6 * 10^{6}+\text { Water } V}{47.8} * \frac{1}{111.8+T}, \text { S.th }>60, e(-9,+9)\end{array}\right.$

GWM height $=\left\{\begin{array}{l}\frac{16.6 * 10^{6}+\text { Water } V}{1130} * \frac{1}{17.6+T}, \text { S.th }<60, \quad e(-40,+45) \\ \frac{22.7 * 10^{6}+\text { Water } V}{574} * \frac{1}{151.7+T}, \text { S.th }>60, \quad e(-11,+12)\end{array}\right.$ 


\subsubsection{MAR suitability maps}

Fig. 6.13 shows MAR suitability maps based on subsurface characteristics for different scenarios of $\mathrm{K}$ and collection capacity.

Suitability maps show the ability to implement MAR over a wide area of northern Wadis, which coincide with the Basalt Aquifer, for all scenarios of $\mathrm{K}$ and collection capacity. The suitability of sites for MAR in wadis over the B45 aquifer is poor. The figure shows the possibility to recharge the 50th percentile of monthly runoff in the respective wadi over a small area of wadi Rajil considering this site has the same $\mathrm{K}$ as the regional aquifer value. However, the $50^{\text {th }}$ percentile can't be recharged if site's $\mathrm{K}$ is 0.5 of regional calibrated value of $\mathrm{K}$.

MAR is suitable over a large area of wadi Jesha to recharge the 50th percentile of monthly surface runoff. Suitability for the 80th percentile is reduced considerably.

After screening out unsuitable sites for MAR, suitability levels (very suitable and less suitable) are applied using criteria mentioned in Table 6.3, see Fig. 6.14.

Generated suitability maps based on different scenarios of hydraulic conductivity demonstrate the importance of this factor and the necessity to investigate it more in MAR studies.

The decision if MAR's capacity should be designed to capture the 50th, 80th or any other percentile of monthly surface runoff has some economic considerations. Taking into account the high variability of storm water in arid areas, a collection capacity of MAR structure based on a high percentile has an inflated cost per water-unit. Other than economic constraint, suitability of sites to accommodate large amount of water could also influence the decision. The generated suitability maps of the study region for different scenarios of water collection can be used by managers when making the decision on the scale of MAR structure when storm water is highly variable.

the results are still exposed to uncertainty due to a number of factors:

- Wrong estimation of infiltration rate will change the time of infiltration. Smaller infiltration rate will lead to longer time of infiltration which would result in a lower groundwater mound, and vice versa. 


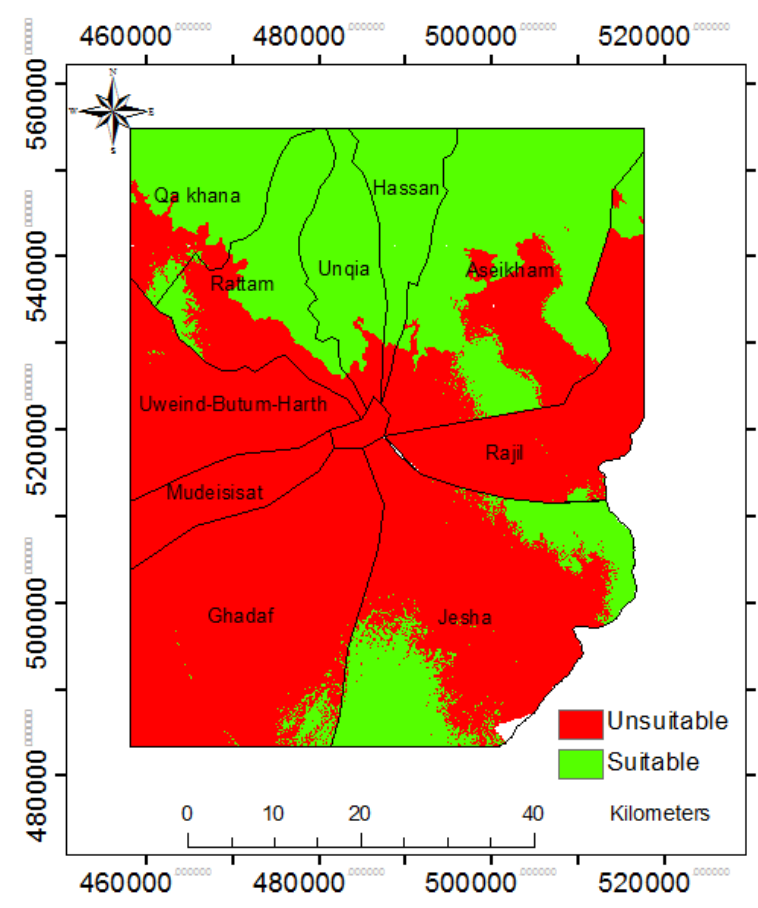

(a)

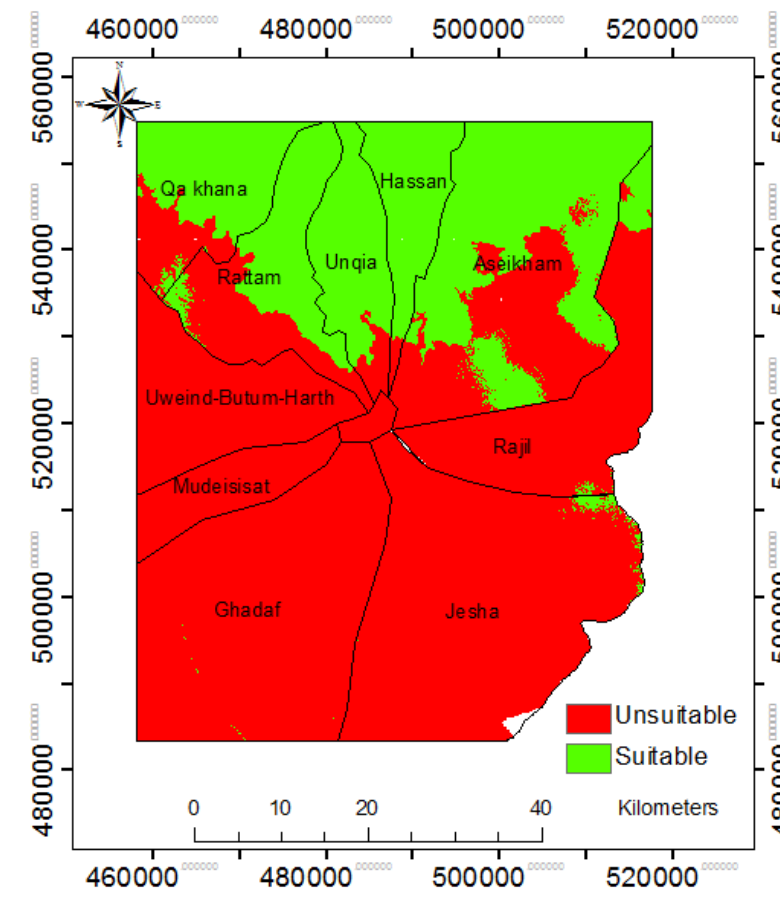

(c)

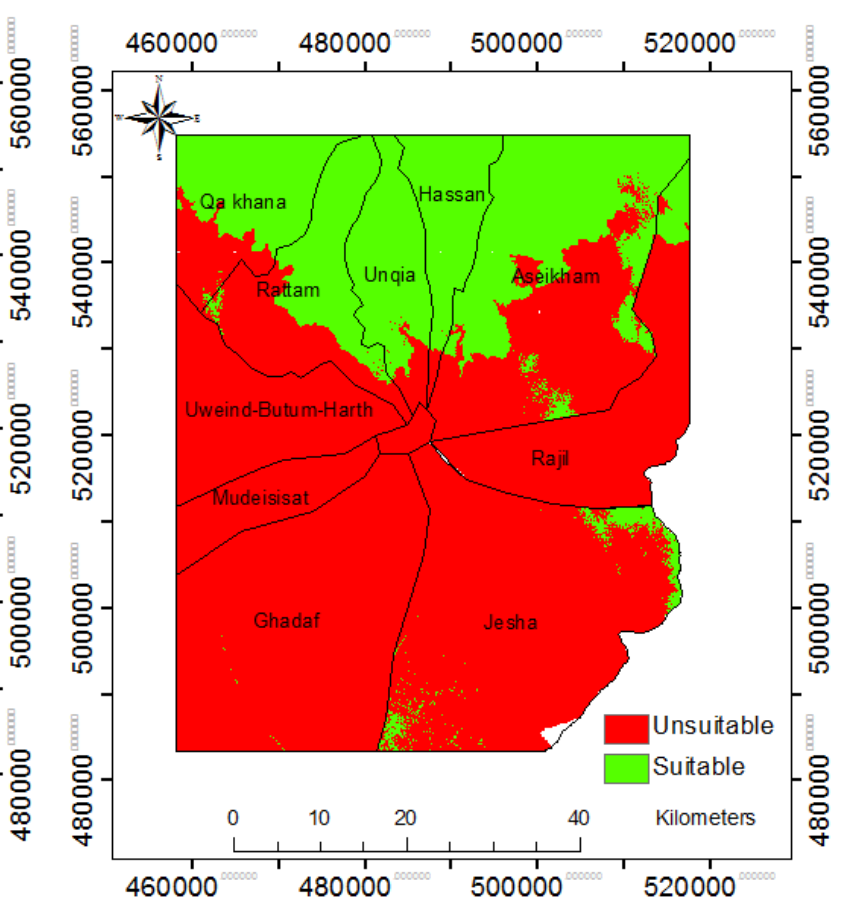

(b)

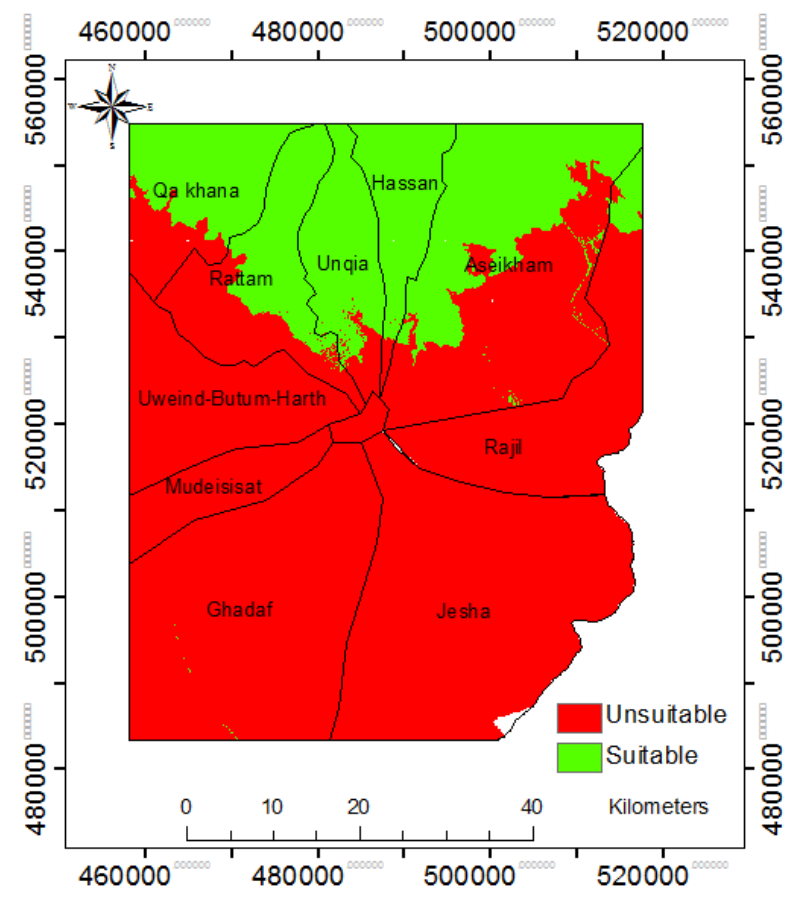

(d)

Fig. 6.13: MAR suitability maps based on subsurface characteristics for different scenarios of $K$ and collection capacity a: (calibrated $K, 50^{\text {th }}$ percentile of Runoff), b: (calibrated $\mathrm{K}, \mathbf{8 0}^{\text {th }}$ percentile of Runoff), c: $\left(50 \%\right.$ calibrated $\mathrm{K}, 50^{\text {th }}$ percentile of Runoff) d: (50\% calibrated $\mathrm{K}, \mathbf{8 0}^{\text {th }}$ percentile of Runoff) 


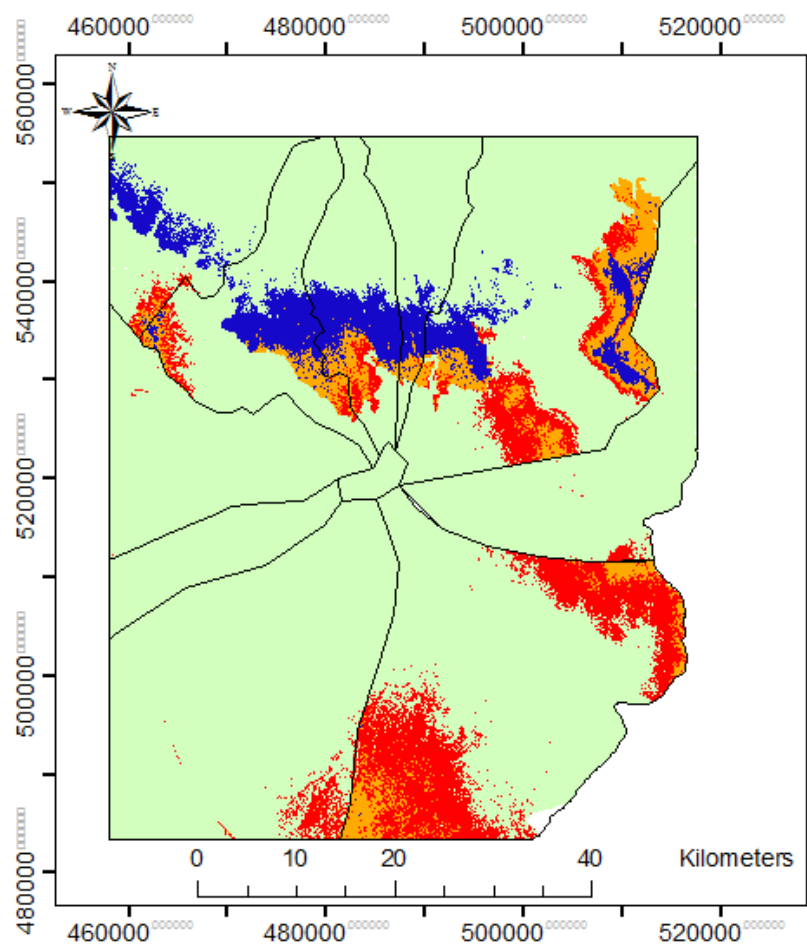

Suitability Map

Subsurface Factors

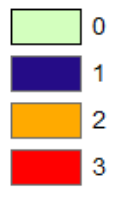

(a)

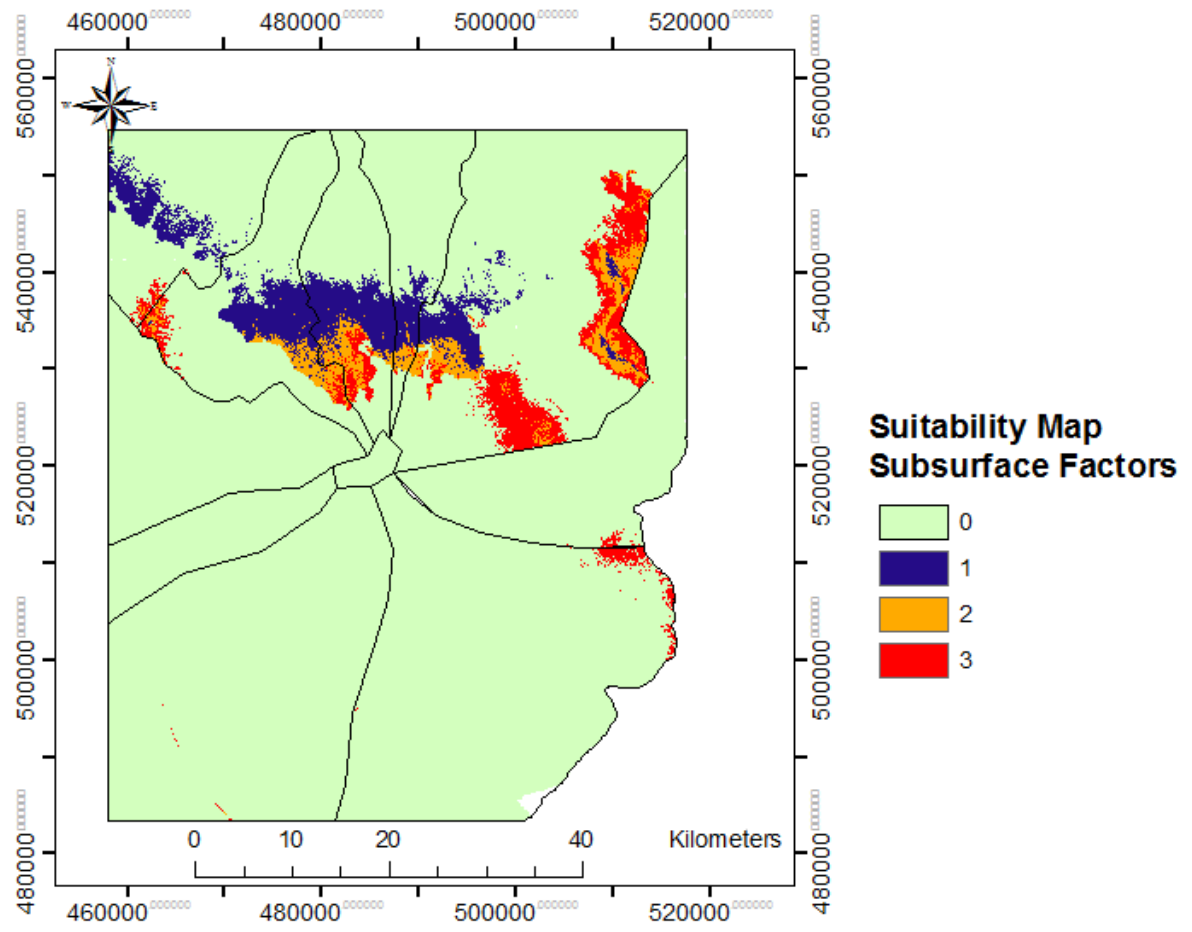

(b)

Fig. 6.14: Suitability maps for MAR implementation with suitability degrees based on subsurface characteristics for 2 scenarios of collection capacity a: $50^{\text {th }}$ and $b: 8^{\text {th }}$ percentile of monthly surface runoff in the respective wadi 
- Clogging problems can be faced as a result of sediment transport into the structure, which would decrease the assumed infiltration rate considerably.

- A deviation of the structure's design from the assumed designed (the dimensions and capacity of the infiltration basin) will lead to different results.

- The impacts of water flow in the unsaturated zone on the formation of mounding weren't not considered.

Suitability map generated based on surface characteristics is shown in Fig. 6.15. The final MAR suitability maps for the 2 scenarios of collection capacity of MAR structures are depicted in Fig. 6.16.

The generated maps are considered as a first step for the delineation of suitable sites for MAR. Site-specific analysis (infiltration and pumping test, detection of impervious layers in the vadose zone) is still necessary before making the final decision regarding the suitability of a site.

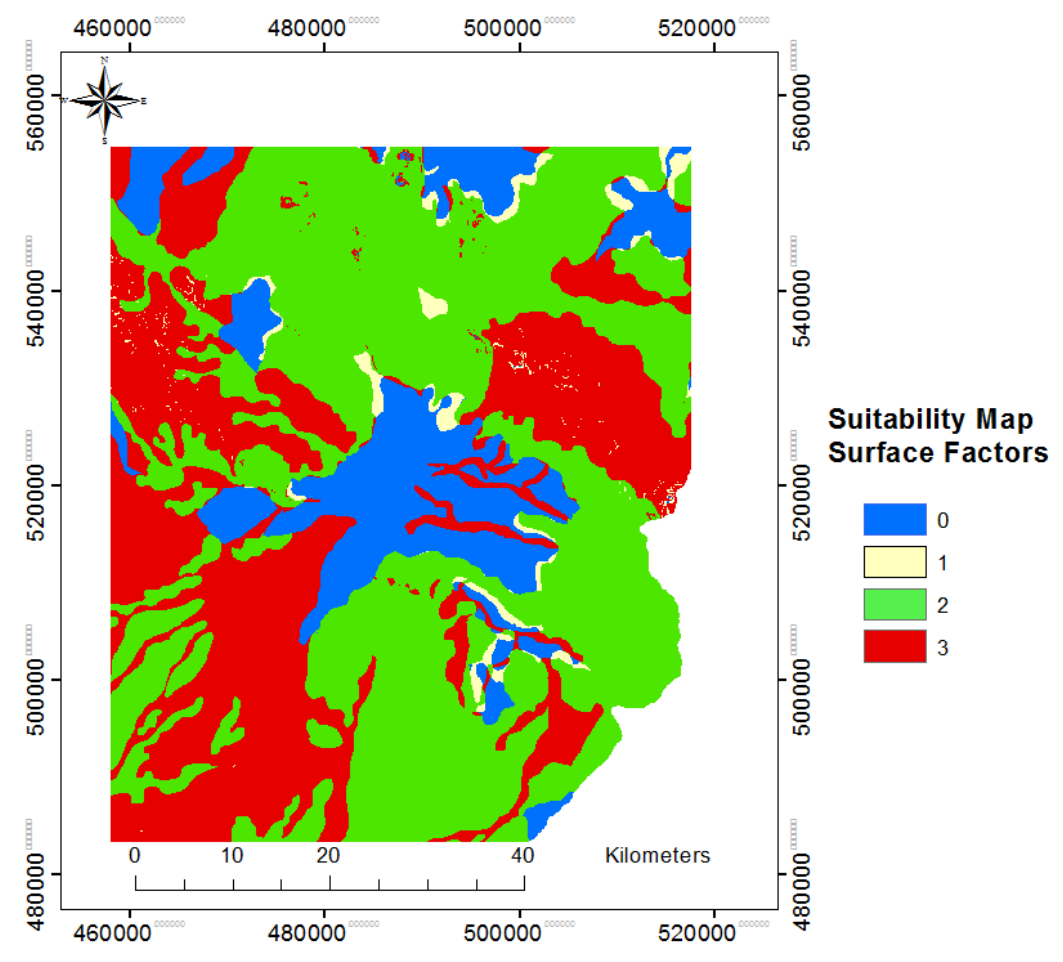

Fig. 6.15: MAR suitability maps based on surface characteristics 


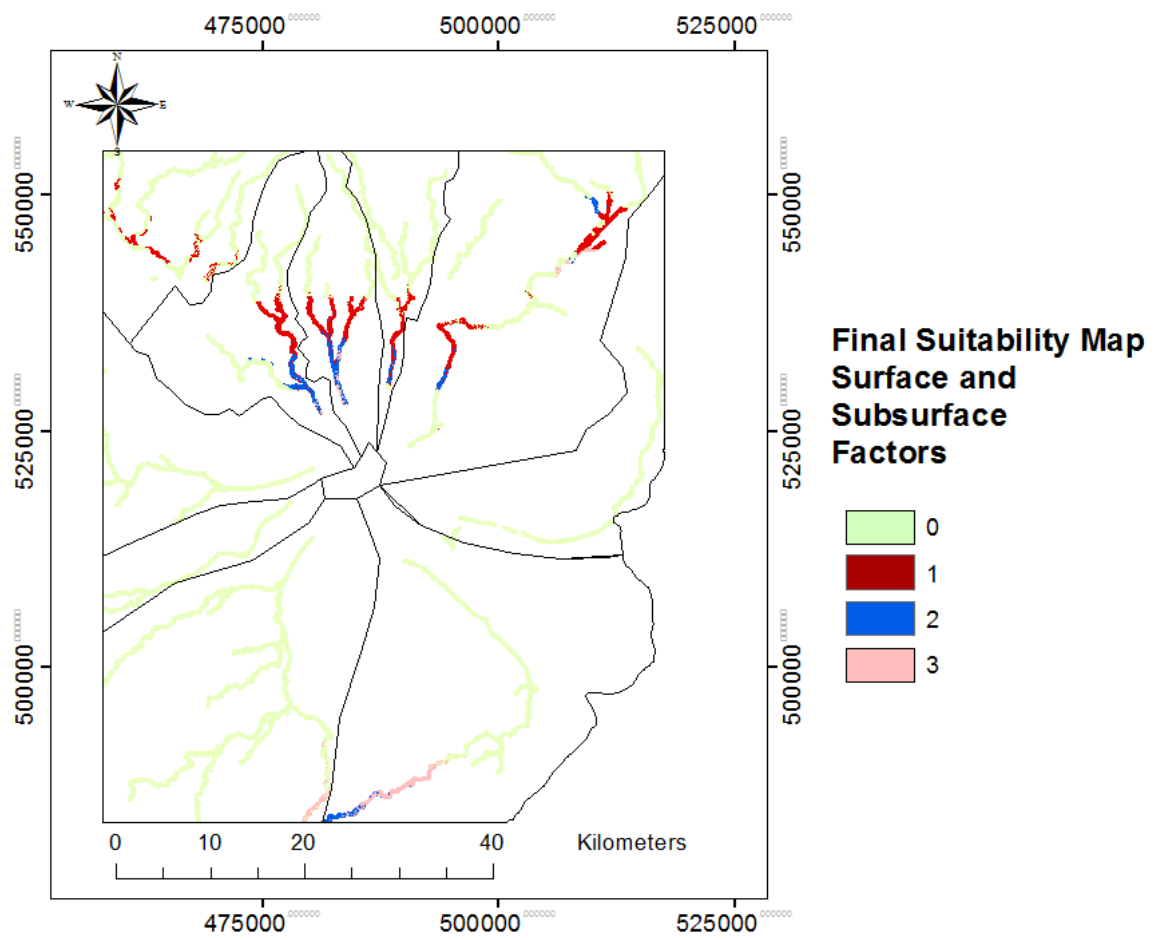

(a)

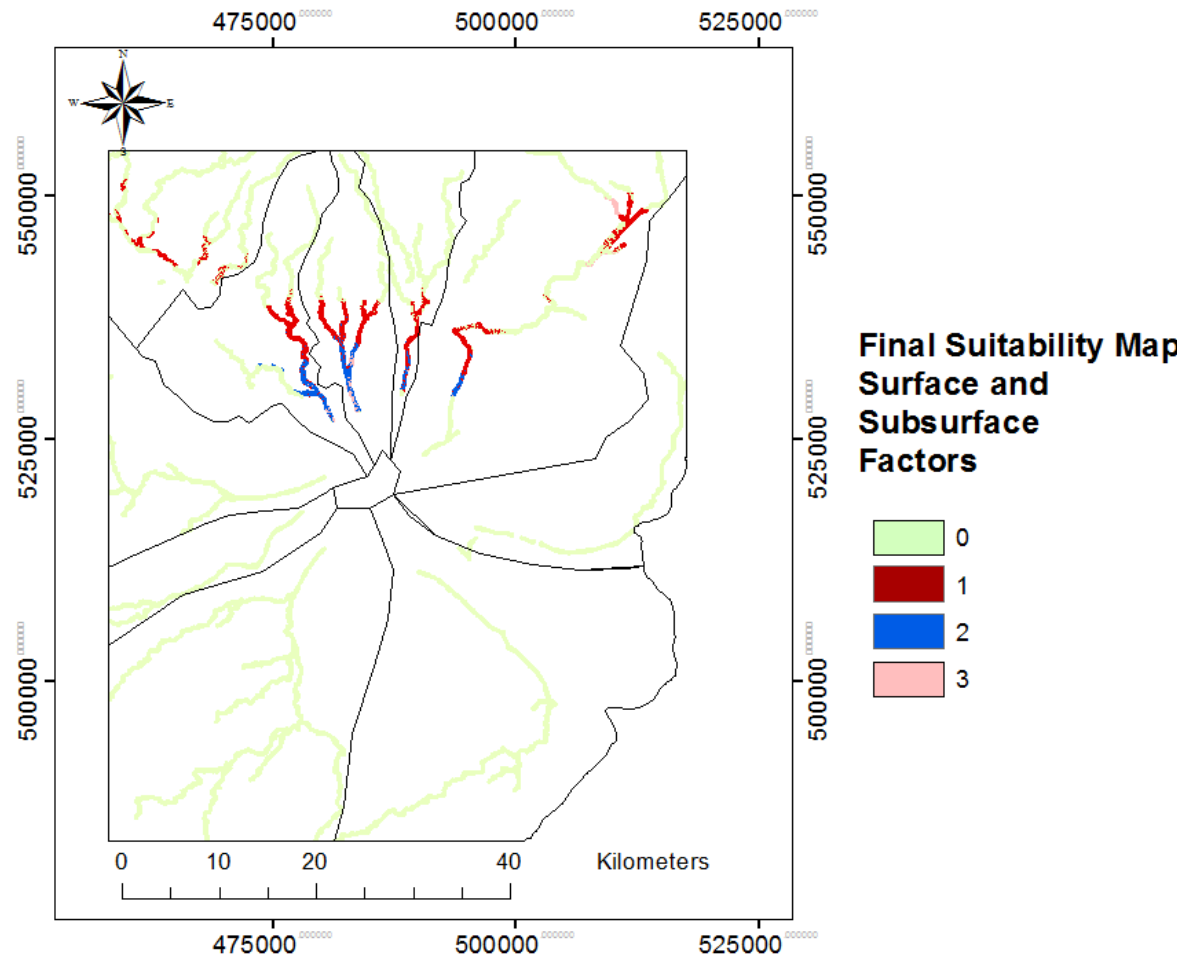

(b)

Fig. 6.16: Final MAR suitability maps based on surface and subsurface characteristics for 2 scenarios of dam's collection capacity a: $50^{\text {th }}$ percentile and b: $80^{\text {th }}$ percentile of monthly surface runoff in the respective wadi. 
Initially, 3 MAR dams were proposed in the basin, Fig. 6.17 shows the location of MAR structures and the respective surface catchments. Table 6.7 shows the names of surface catchments of MAR structures, their areas and the 50th and 80th percentile of monthly surface runoff in the respective catchment.

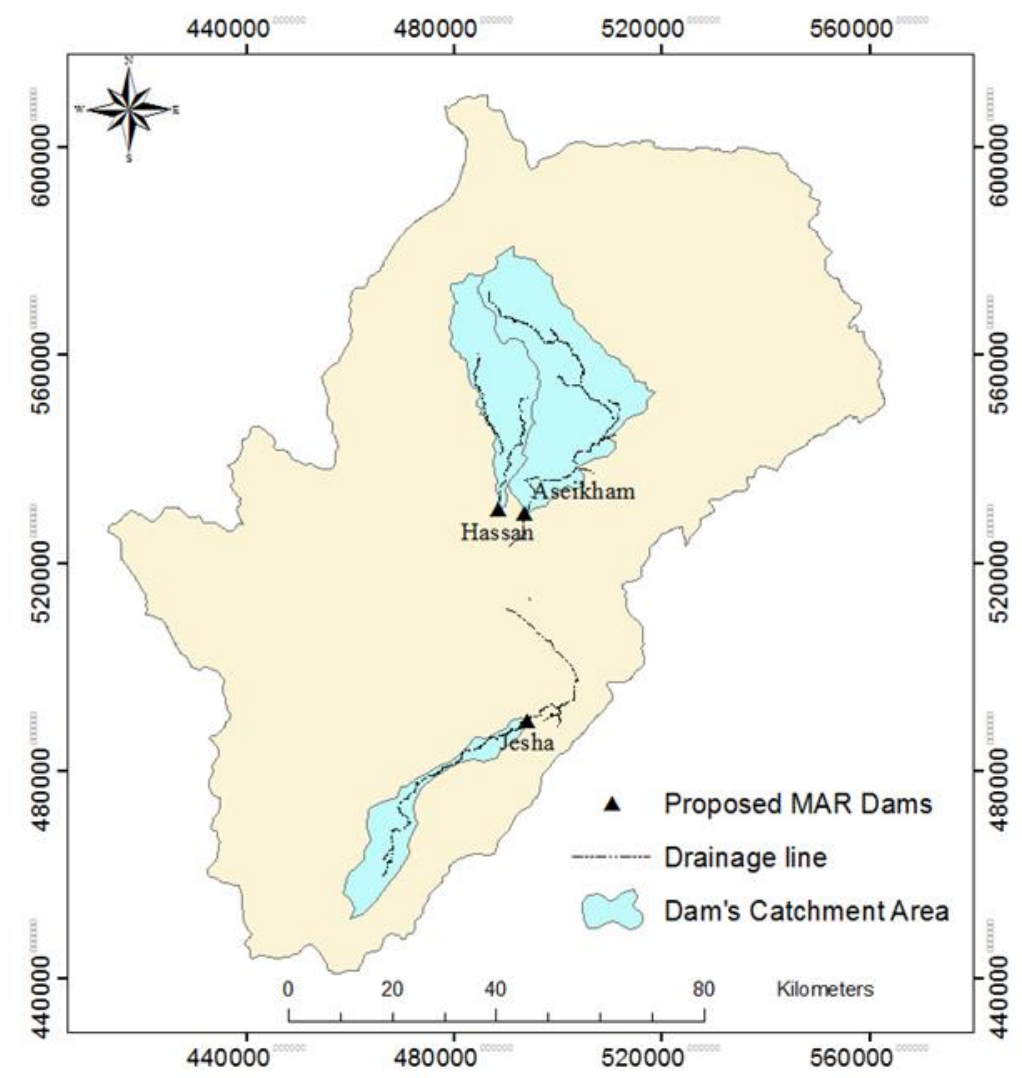

Fig. 6.17: Locations of proposed MAR structures in the study area.

Table 6.7: Catchment areas of proposed MAR structures and respective 50th and 80th percentiles of monthly runoff

\begin{tabular}{|c|c|c|c|}
\hline $\begin{array}{c}\text { Wadi's } \\
\text { name }\end{array}$ & $\begin{array}{c}\text { Catchment } \\
\text { area } \mathbf{K m}^{\mathbf{2}}\end{array}$ & $\begin{array}{c}\mathbf{5 0}^{\text {th }} \text { percentile of monthly } \\
\text { surface runoff, MCM }\end{array}$ & $\begin{array}{c}\text { 50th percentile of monthly } \\
\text { surface runoff, MCM }\end{array}$ \\
\hline Aseikham & 742 & 0.19 & 0.36 \\
\hline Hassan & 349 & 0.47 & 0.82 \\
\hline Jesha & 243 & 0.24 & 0.48 \\
\hline
\end{tabular}




\section{Assessing management strategies in the basin}

\subsection{Introduction}

As described in Chapter 2, the Shallow Aquifer System in Azraq basin has been over-exploited in the last years, and groundwater table has been declining at a rate of $1 \mathrm{~m} /$ year. If the same pumping behavior continued the future use of the aquifer will be compromised. Therefore, it is needed to introduce and assess some management options to prevent aquifer deterioration.

This chapter is on model application and decision making. Aquifer behavior under different pumping scenarios and possible shifts in groundwater recharge is simulated, and aquifer's safe yield is determined. MAR scenarios are applied to analyze the contribution of MAR to the solution of the water crisis. Finally, possible management alternatives are assessed under conflicting environmental and socio-economic criteria.

\subsection{Definition of the Safe Yield}

The rate at which groundwater can be withdrawn from an aquifer without causing undesirable adverse effects is called the Safe Yield (Dottridge \& Jaber, 1999). Meinzer (1923) defined safe yield as the pumping rate from an aquifer that doesn't deplete the supply to such an extent that withdrawal is no longer economically feasible. Voudouris (2006) estimated the safe yield from the calculation of the exploitable dynamic groundwater reserve at aquifer in Vocha plain, Greece. The withdrawn of exactly the dynamic groundwater reserve will keep the groundwater level at a constant rate. Liu (2015) applied the Hill method (Freeze and Cherry 1979) that plots simulated pumping rate against drawdown to determine the safe yield of the aquifer in Taipei Basin, Taiwan.

The safe yield in Azraq basin will be defined as the amount of water that can be pumped out with no further decline of groundwater table over the coming years. 


\subsection{Model application}

\subsubsection{Simulation under pumping scenarios}

A number of pumping scenarios are tested in the basin for the next 30 years. Pumping scenario One would be to continue pumping at the current abstraction rate, defined as the average pumping rate in the years (2008-2012) (Fig. 7.1). This abstraction rate is reduced $10 \%$ at a time, and the response of groundwater table is realized. Abstraction rate for which no decline in groundwater table is noticed is the safe yield of the aquifer.

The results of simulations show that, if the current pumping patters continue, groundwater table will decline at an average rate of $0.6 \mathrm{~m} / \mathrm{year}$ and average groundwater table decline will be $20 \mathrm{~m}$ by the year 2045 . Fig. 7.2 depicts simulated groundwater fluctuation at monitoring wells (1014 and1126) in the basin under this scenario.

Table 7.1 shows simulated groundwater table decline by the year 2045 under some pumping scenarios. It can be seen that the Safe Yield of the aquifer is 30\% of the average pumping rate in recent years, which indicates that the basin is being largely exploited beyond its capacity. Table 7.2 and Table 7.3 show the rate of groundwater decline $\mathrm{m} /$ day and the percentage of remaining saturated thickness by the year 2045 for different pumping scenarios respectively. Fig. 7.3 depicts simulated groundwater head at monitoring wells (F1014 and1F126) in the basin for the Safe Yield scenario.

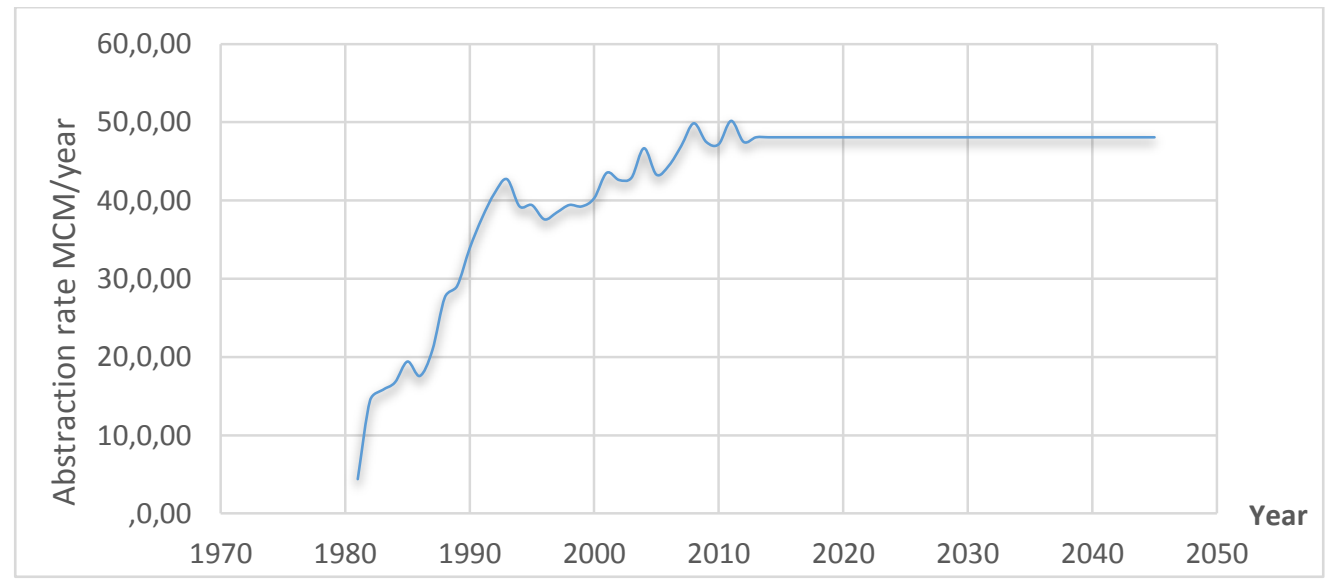

Fig. 7.1: Abstraction rate of pumping scenario One 

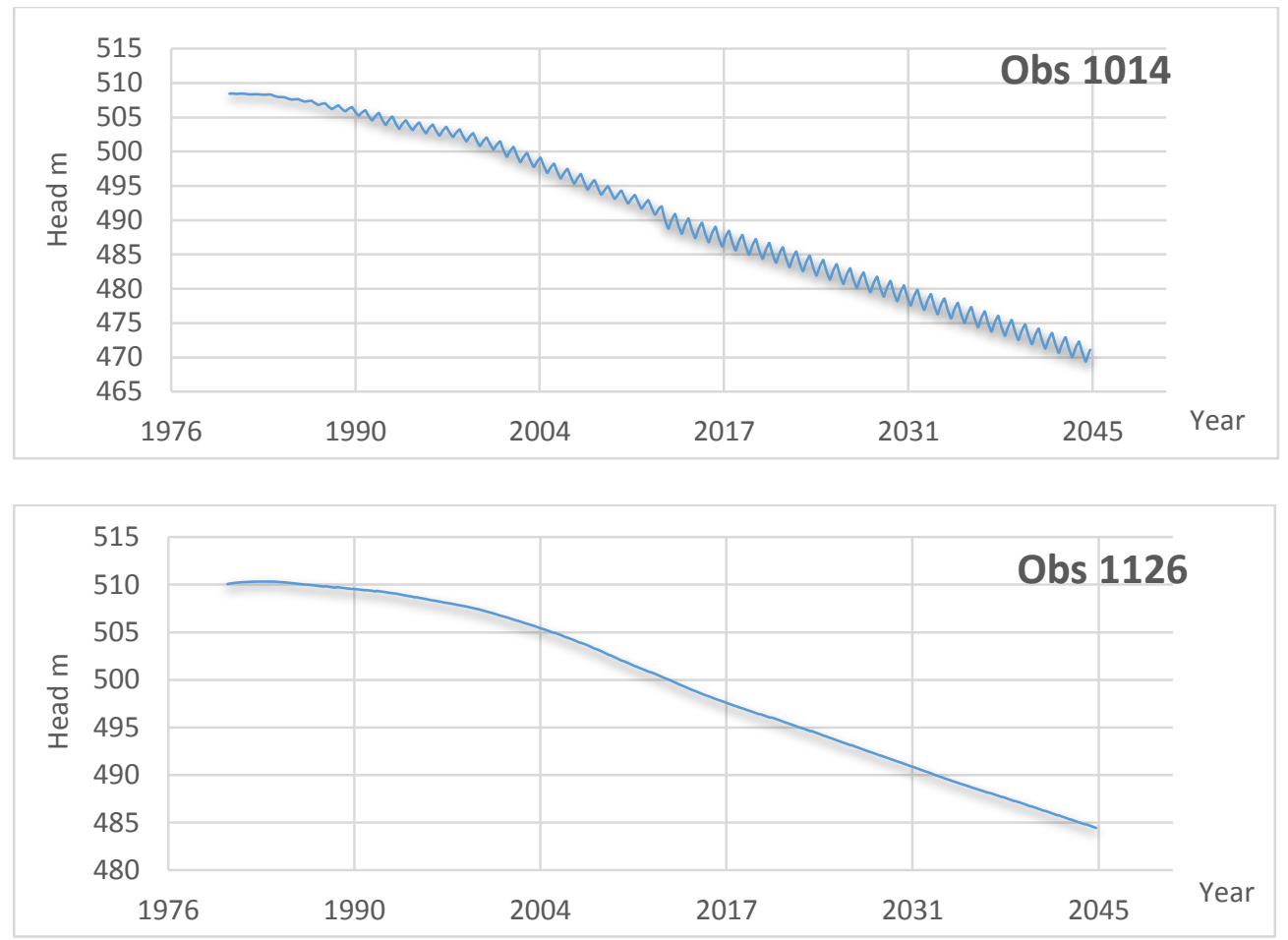

Fig. 7.2: Simulated groundwater head under pumping scenario One.
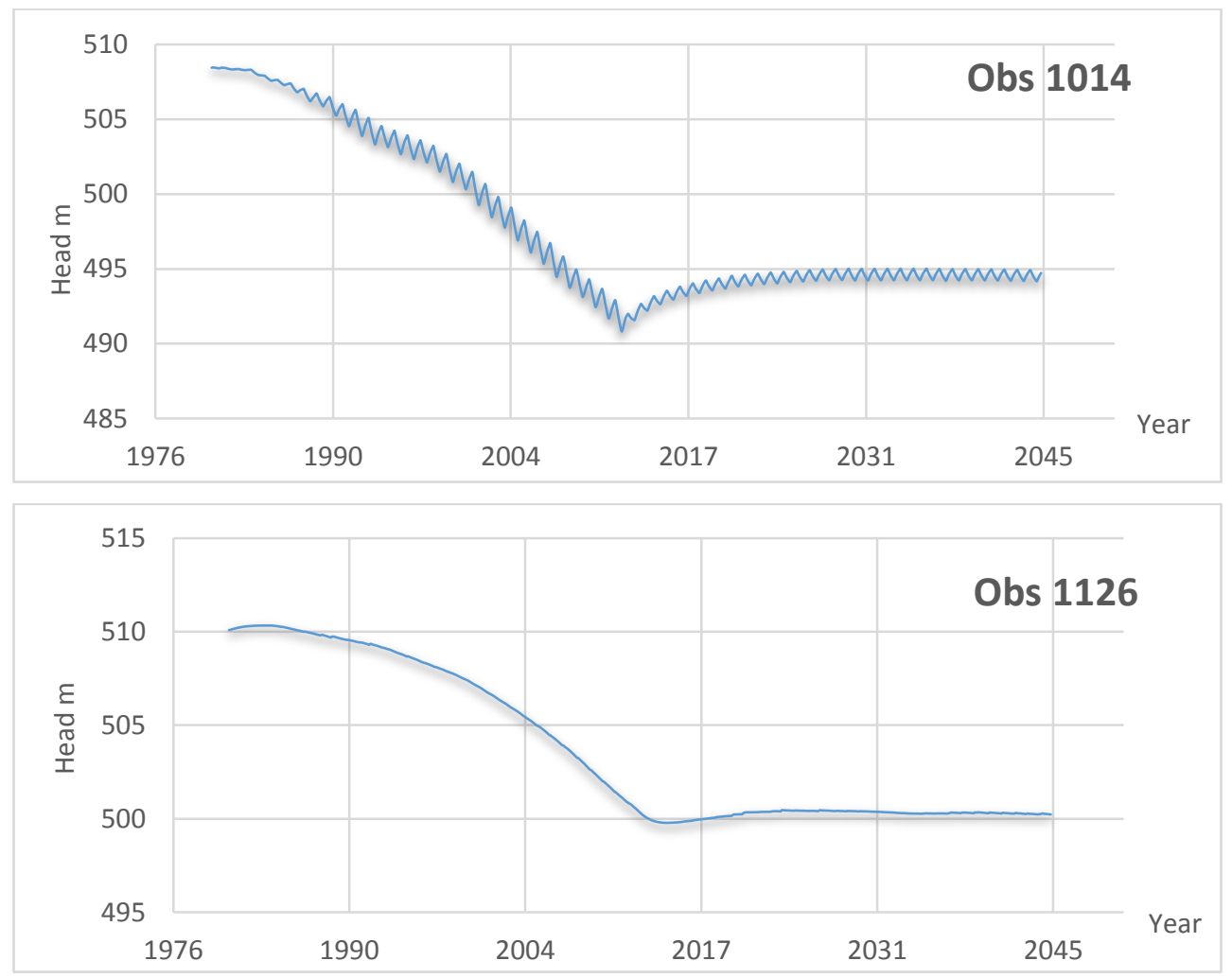

Fig. 7.3 Simulated groundwater head under the safe yield scenario 
Table 7.1: Simulated groundwater table decline by the year 2045 at monitoring wells under different pumping scenarios

\begin{tabular}{|c|c|c|c|c|c|}
\hline & & \multicolumn{3}{|c|}{$\begin{array}{c}\text { Groundwater table decline } \\
\text { (meter) by 2045 at monitoring } \\
\text { wells }\end{array}$} \\
\hline Scenario & Description & F1014 & F1022 & F1126 & F1280 \\
\hline 1 & $\begin{array}{c}\text { Pumping continues at current } \\
\text { abstraction rate }\end{array}$ & -20.70 & -24.00 & -16.50 & -23.50 \\
\hline 2 & $\begin{array}{c}\text { Pumping rate equals } 80 \% \text { of current } \\
\text { pumping rate }\end{array}$ & -14.50 & -17.50 & -12.70 & -17.20 \\
\hline 3 & $\begin{array}{c}\text { Pumping rate equals 50\% of current } \\
\text { pumping rate }\end{array}$ & -5.30 & -6.20 & -6.80 & -7.70 \\
\hline 4 & $\begin{array}{c}\text { Pumping rate equals 40\% of current } \\
\text { pumping rate }\end{array}$ & -2.10 & -2.70 & -4.70 & -4.40 \\
\hline 5 & $\begin{array}{c}\text { Pumping rate equals 30\% of current } \\
\text { pumping rate }\end{array}$ & 1.60 & 1.00 & -2.53 & -1.00 \\
\hline
\end{tabular}

Table 7.2: Future rate of groundwater table decline by the year 2045 at monitoring wells under different pumping scenarios

\begin{tabular}{|c|c|c|c|c|c|}
\hline \multirow[b]{2}{*}{ Scenario } & \multirow[b]{2}{*}{ Description } & \multicolumn{4}{|c|}{$\begin{array}{c}\text { Future rate of groundwater } \\
\text { decline } \mathrm{m} \text { /year at monitoring } \\
\text { wells }\end{array}$} \\
\hline & & F1014 & F1022 & F1126 & F1280 \\
\hline 1 & $\begin{array}{l}\text { Pumping rate equals last } 5 \text { years } \\
\text { average pumping rate }\end{array}$ & -0.65 & -0.75 & -0.52 & -0.73 \\
\hline 2 & $\begin{array}{l}\text { Pumping rate equals } 80 \% \text { of last } 5 \\
\text { years average pumping rate }\end{array}$ & -0.45 & -0.55 & -0.40 & -0.54 \\
\hline 3 & $\begin{array}{l}\text { Pumping rate equals } 50 \% \text { of last } 5 \\
\text { years average pumping rate }\end{array}$ & -0.17 & -0.19 & -0.21 & -0.24 \\
\hline 4 & $\begin{array}{l}\text { Pumping rate equals } 40 \% \text { of last } 5 \\
\text { years average pumping rate }\end{array}$ & -0.07 & -0.08 & -0.15 & -0.14 \\
\hline 5 & $\begin{array}{l}\text { Pumping rate equals } 30 \% \text { of last } 5 \\
\text { years average pumping rate }\end{array}$ & 0.05 & 0.03 & -0.08 & -0.03 \\
\hline
\end{tabular}


Table 7.3: Percentage of remaining aquifer' saturated thickness by the year 2045 at monitoring wells under different pumping scenarios

\begin{tabular}{|l|l|l|l|l|l|}
\hline \multirow{2}{*}{} & & \multicolumn{4}{|c|}{$\begin{array}{c}\text { Percentage of remaining } \\
\text { saturated thickness (\%) at } \\
\text { monitoring wells }\end{array}$} \\
\hline Scenario & Description & \multicolumn{3}{|c|}{ F1126 } & F1280 \\
\hline 1 & $\begin{array}{l}\text { Pumping rate equals last 5 years } \\
\text { average pumping rate }\end{array}$ & 91 & 52 & 77.5 & 84 \\
\hline 2 & $\begin{array}{l}\text { Pumping rate equals 80\% of last 5 } \\
\text { years average pumping rate }\end{array}$ & 94 & 65 & 82.5 & 88.5 \\
\hline 3 & $\begin{array}{l}\text { Pumping rate equals 50\% of last 5 } \\
\text { years average pumping rate }\end{array}$ & 98 & 87.5 & 91 & 94.5 \\
\hline 4 & $\begin{array}{l}\text { Pumping rate equals 40\% of last 5 } \\
\text { years average pumping rate }\end{array}$ & 99 & 94.5 & 93.5 & 97 \\
\hline 5 & $\begin{array}{l}\text { Pumping rate equals 30\% of last 5 } \\
\text { years average pumping rate }\end{array}$ & 100.5 & 102 & 96.5 & 99 \\
\hline
\end{tabular}

\subsubsection{Simulation under climate change scenario}

In the determination of aquifer' Safe Yield previously, no future change in climatic patterns was assumed. However, it is important to understand how much the Safe Yield may change as a result of a shift in groundwater recharge imposed by climate change.

For the generation of future groundwater recharge scenario, numerous General Circulation Models (GCMS) provide different scenarios of future climate change. Where a GCM performs well in a certain area, it doesn't necessarily provide plausible projections of future climate in another area. Some criteria were suggested by the Intergovernmental Panel on Climate Change (IPCC) for favoring a GCM in an area over the others, such as resolution, validity and representativeness of result, however, it was stressed out that none of these suggestions can ensure the superiority of a certain GCM over the others. GCMs offer different prediction of future precipitation and temperature in North of Jordan (MOE and UNDP, 2009), however, many of them e.g. ECHAM5OM. general circulation model, Max Planck Institute for Meteorology, Germany and HADGEM1. HADley Center Global Climate Model, UK. are in agreement 
regarding the decreasing trend in precipitation and increasing expected air temperature, which will lead to a decrease in groundwater recharge.

As different scenarios of groundwater recharge will be obtained based on the chosen GCM and the chosen scenario, two simple scenarios of future groundwater recharge were assumed; $25 \%$ and $50 \%$ decrease.

Simulation results show that $25 \%$ and $50 \%$ decrease in groundwater recharge for the next 30 years will have negligible impacts on the groundwater table level in the center of the basin, where the majority of discharge take place. Under these two scenarios of groundwater recharge the safe yield of the aquifer remains the same, which indicate that the groundwater in the basin is fossil water, and the aquifer can be considered as a non-renewable resource.

\subsubsection{Simulation under MAR scenario}

By comparing the Safe Yield of the basin with current abstraction rate it is clear that the basin is being exploited beyond its limits. MAR is usually applied with the purpose of enhancing the water supply. The application of MAR in the basin is tested for its effectiveness in increasing the Safe Yield and achieving a more sustainable management in the basin.

Each of the pumping scenarios previously tested are combined with 2 MAR scenarios. In the first and second scenarios, MAR structure is assumed to capture the $50^{\text {th }}$ and $80^{\text {th }}$ percentile of monthly amount of surface runoff in the respective wadi respectively. The design of MAR scheme and the location of dams are explained in Chapter 6. The amount of monthly surface runoff in the wadis of the basin is calculated in Chapter 4. The response of groundwater table at monitoring wells under the different MAR scenarios is realized.

Table 7.4 shows simulated groundwater table decline by the year 2045 for two pumping scenarios, each combined with 2 MAR scenarios where MAR collection capacity is designed to capture the $50^{\text {th }}$ and $80^{\text {th }}$ percentile of monthly runoff at the respective wadi.

The results show that the application of MAR in the basin doesn't contribute greatly to increasing the safe yield. Under MAR scenario where the capacity of 
MAR dam is designed based on the $50^{\text {th }}$ and $80^{\text {th }}$ percentiles of monthly surface runoff, groundwater head will increase 0.7 and $1 \mathrm{~m}$ by the year 2045 respectively.

Table 7.4: Simulated groundwater table decline by the year 2045 under pumping and MAR scenarios

\begin{tabular}{|l|l|l|l|l|}
\hline & \multicolumn{3}{|c|}{$\begin{array}{l}\text { groundwater table decline (meter) } \\
\text { by 2045 at monitoring wells }\end{array}$} \\
\hline Scenario Discerption & F1014 & F1022 & F1126 & F1280 \\
\hline $\begin{array}{l}\text { pumping rate equals 50\% of last 5 years } \\
\text { average }\end{array}$ & -5.3 & -6.2 & -6.8 & -7.7 \\
\hline $\begin{array}{l}\text { Pumping rate equals 50\% of last 5 years } \\
\text { average + MAR scenario 50th percentile }\end{array}$ & -4.5 & -5.5 & -6.4 & -6.9 \\
\hline $\begin{array}{l}\text { Pumping rate equals 50\% of last 5 years } \\
\text { average + MAR scenario 80th percentile }\end{array}$ & -4.3 & -5.3 & -6.3 & -6.6 \\
\hline $\begin{array}{l}\text { pumping rate equals 40\% of last 5 years } \\
\text { average }\end{array}$ & -2.10 & -2.70 & -4.70 & -4.40 \\
\hline $\begin{array}{l}\text { pumping rate equals 40\% of last 5 years } \\
\text { average + MAR scenario 50th percentile }\end{array}$ & -1.35 & -2.00 & -4.30 & -3.60 \\
\hline $\begin{array}{l}\text { Scenario, pumping rate equals 40\% of last 5 } \\
\text { years average + MAR scenario 80th percentile }\end{array}$ & -1.00 & -1.70 & -4.20 & -3.30 \\
\hline
\end{tabular}

\subsection{Application of Multi-criteria-Analysis in choosing abstraction rate in Azraq basin}

\subsubsection{Overview}

Groundwater flow model for the basin has been prepared in many studies, where the calibrated flow model was used to assess the future behavior of the aquifer under certain pumping scenarios, e.g. present pumping rate, and 1.5 present pumping rate (Abdulla et al., 1999), current pumping rate, reducing the current pumping rate by half, no pumping from the well-field (Alkharabsheh, 2000), reducing the current pumping rates by half, increasing pumping rate by half, 
reducing pumping rate in public wells by half, reducing pumping rates in private wells by half (Abu-El-Sha'r and Hatamleh, 2007). The impacts of such management alternatives on groundwater drawdown were assessed; however, the extent to which these solutions are accepted socially and economically wasn't discussed.

The term Integrated Water Resources Management (IWRM) was introduced to explain the sustainable development of adopted projects (GWP, 2000). According to IWRM guideline, development and management of water, land, and related resources must take into consideration three important elements; ecological sustainability, economic efficiency, and social equity

Multi-criteria decision analysis (MCDA) is an approach to decision making in order to assess multiple objectives and variables in complex situations. Among the many MCDA methods, the Analytic Hierarchy Process (AHP) (Saaty, 1980) is an effective tool for setting priorities and making the best decision among a number of alternative options based on a set of evaluation criteria. It is able to translate evaluation criteria (both qualitative and quantitative) made by the decision maker into a multi-criteria ranking based on comparable scores.

AHP has been applied in multiple criteria decision-making in several fields especially in water management. Kalbr et al. (2013) used AHP in the decision on appropriate wastewater treatment alternatives taking into account criteria such as; global warming, eutrophication, life cycle costs, land requirement, manpower, robustness of the system, sustainability. In the selection of waste water treatment technology, social, environmental, technical and economic criteria were considered by Ilangkumaran (2013).

AHP was also applied in the selection of most suitable sites for irrigation based on criteria such as land suitability, resources, cost, social and environmental (Anane, 2012), in the evaluation of watershed nutrient planning strategies based on criteria such as; watershed, agriculture, water supply, appropriate development, cost effectiveness, community, quality of life, appropriate technology, reduce hassle and cost equitably (Bosch, 2012) and in the selection of most suitable leakage management alternatives based on criteria such as planning development, cost, damage to properties and supply disruptions (Delgado-Galván, 2010). 
In this research AHP will be applied to analyze proposed management alternatives (different decreased pumping rates). Along with the impacts of these management solutions on the aquifer, the socio-economic aspects will be integrated in the decision making.

\subsubsection{Application of Analytic Hierarchy Process}

In AHP the decision problem is first decomposed into a hierarchy of easily comprehended sub-problems. The decision makers can then evaluate the elements by comparing them to each other two at a time, with respect to their impact or importance on an element above them. The importance of criteria is compared first with respect to the goal, and then a pairwise comparison is carried among alternatives with respect to each criterion. AHP allows the comparison between qualitative criteria which may not be measurable in monetary or other units. For judgments of 'intensity of importance' a number (score) is assigned for each pair of two criteria/alternatives that describes the relative importance of one over the other (Table 7.5).

Table 7.5: Scale of relative importance for AHP method

\begin{tabular}{|l|l|l|}
\hline $\begin{array}{l}\text { Intensity of } \\
\text { importance }\end{array}$ & Definition & Explanation \\
\hline 1 & Equal importance & $\begin{array}{l}\text { Two activities contribute equally to the } \\
\text { objective }\end{array}$ \\
\hline 3 & $\begin{array}{l}\text { Moderate importance } \\
\text { of one over another }\end{array}$ & One is slightly in favor over another \\
\hline 5 & Essential or strong & One is strongly in favor over another \\
\hline 7 & Very strong importance & $\begin{array}{l}\text { One is strongly favored and its dominance is } \\
\text { demonstrated in practice }\end{array}$ \\
\hline 9 & Absolute importance & $\begin{array}{l}\text { The evidence favoring one over another is of } \\
\text { the highest possible order of affirmation }\end{array}$ \\
\hline
\end{tabular}

At each time, a preference matrix is created. For $\mathrm{n}$ number of elements (criteria/alternatives) and where the relative importance of two elements $(\mathrm{Ci}, \mathrm{Cj})$ is denoted as $\left(a_{i j}\right)$, a square matrix $A=\left(a_{i j}\right)$ of order $\mathrm{n} i$ s formed with the constraints that $a i j=1 / a j i$, for $i \neq j$, and $a i i=1$.

the Eigenvector of the preference matrix represents the partial weights (also called local weights) of criteria/alternatives. 
The Eigenvector $\omega$ of order $\mathrm{n}$ satisfies: $A \omega=\lambda \omega$ where $\lambda$ is the eigenvalue.

$\lambda=n$ for a consistent matrix, however, as setting relative importance involve subjective human judgments, the matrix $\mathrm{A}$ is mostly not consistent, and the eigenvector satisfies: $A \omega=\lambda \max \omega$ where $\lambda \max \geq n$.

The difference between $\lambda \max$ and $n$ is an indication of the inconsistency of the judgments. If $\lambda \max =n$ then the judgements are consistent. a Consistency Index (CI) is calculated using equation (7.1).

$$
C I=(\lambda \max -n) /(n-1)
$$

Consistency Ratio (CR) is calculated to judge on the consistency of our judgments by dividing $\mathrm{CI}$ by the index for the corresponding random matrix.

The application of AHP entails the following steps:

- Identification of relevant decision alternatives and evaluation criteria

- Development of a hierarchical criteria structure

- Specification of relative preferences by pairwise comparison of criteria/alternatives and calculation of partial weights for each preference matrix.

- Ranking the alternative based on their total global weights

\subsubsection{Identification of relevant decision alternatives and criteria}

Five alternative scenarios on the future pumping rate are evaluated in the model. The scenarios are based on average pumping rate in the last 5 years in Azraq. First scenario would be making no action and keep pumping at the same rate. Other scenarios $(80 \%, 60 \%, 40 \%$ and $30 \%$ of average recent pumping rates) are to be evaluated, where $30 \%$ of current pumping rate is the safe yield of the aquifer.

Seven evaluation criteria broken into 4 main categories are considered:

Environmental: A decrease in pumping rate will have direct advantages regarding the preservation of aquifer storage, in addition, it will prevent the dry out of the oasis, and thus preserve the biodiversity that it harbors.

Economic: In the economic criteria, the decrease in farmers' income and increase in incomes from tourism are included. The decrease in pumping rates will have 
direct economic repercussions in the agricultural sector as a result of less irrigation and less production. A decreased pumping rate will preserve the oasis and a larger number of tourists visiting the oasis is expected increasing the revenues from tourism.

Social: The farmers are expected to oppose to a decrease in pumping rates. Additionally, employment and work availability are expected to drop in the agricultural sector with decreased pumping rates.

Cost: the costs that will be considered are pumping costs which will drop with a decrease in pumping rate.

\subsubsection{Development of hierarchical structure}

A hierarchy is visualized as a diagram, with the goal at the top, the five alternatives at the bottom, and the seven criteria in between (Fig. 7.4).

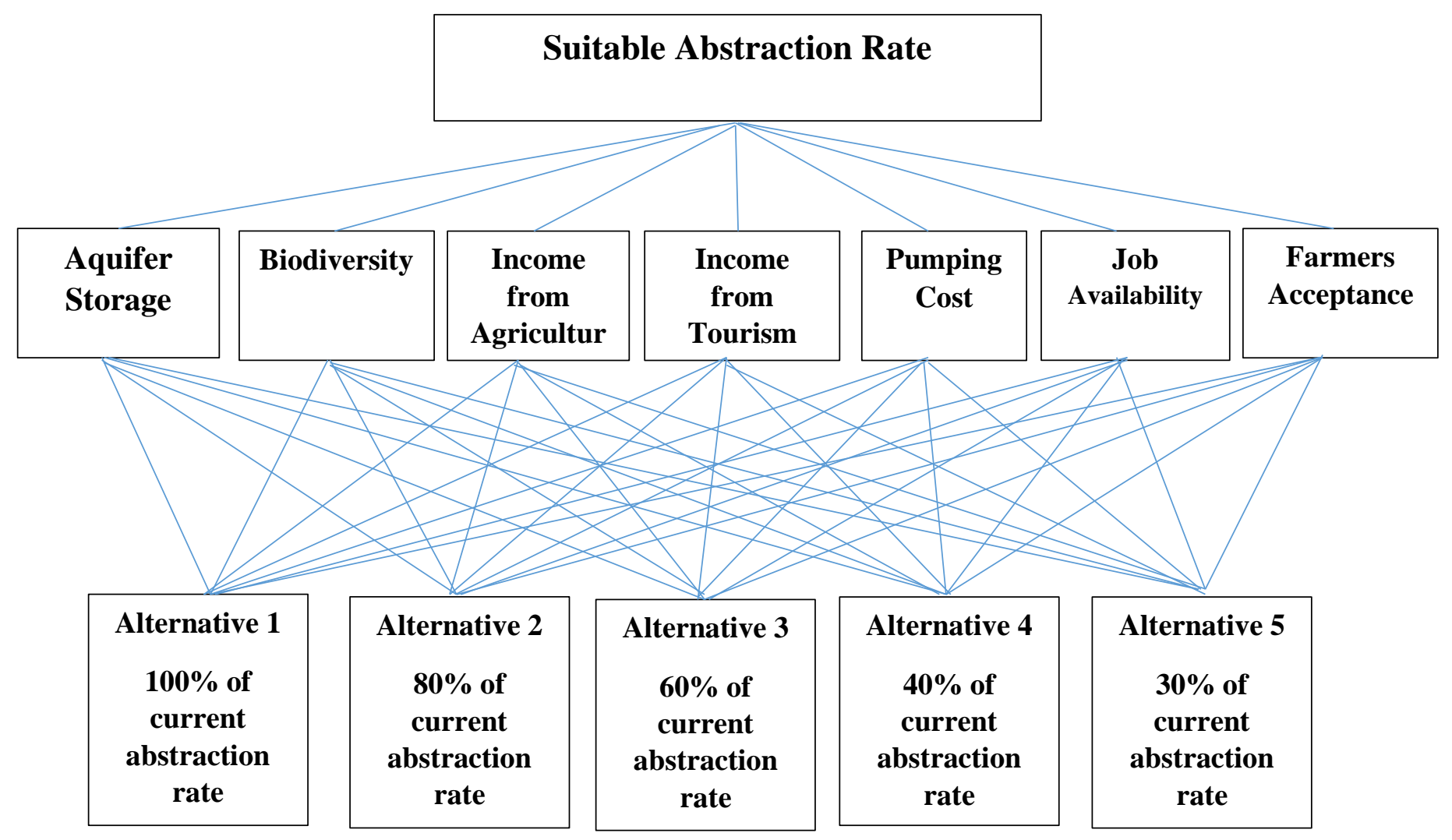

Fig. 7.4: AHP hierarchy for the decision of abstraction rate from the basin 


\subsubsection{Specification of relative preferences and calculation of partial weights}

The AHP reduces complex decisions to a series of pairwise comparisons between two criteria/alternatives. The importance of criteria is compared first with respect to the goal, and then a pairwise comparison is carried among alternatives with respect to each criterion. Scores in Table 7.5 are used for setting the relative importance of one element over the other.

\subsubsection{Comparing the criteria with respect to the goal}

The criteria are compared to how important they are with respect to the goal where each pair of items is compared separately. There are a total of 21 pairs of criteria.

Water resource management is done under conflicting criteria, and active stakeholders in the area should be involved in the process of decision making. The GLOWA Jordan River project is a large interdisciplinary research project devoted to study the impact of climate change in the Middle East. As a part of the GLOWA project, four potential scenarios for the future management of water and environment in the Jordan River valley were developed using the "Story and Simulation" approach. The scenarios describe various alternative socio-economic changes which may take place in the region, including potential economic developments and demographic issues. Stakeholders and scientists in the area were involved in order to gain new insights by using both kinds of knowledge: Stories in a narrative format provided by stakeholders who are familiar with the situation in the region and the specific way water and land resources are managed, as well as scientific information from scientists providing expertise from the respective discipline with which they are engaged.

Comparing the importance of criteria with respect to the decision on abstraction rate from the Azraq basin was done under two of those four scenarios; 'Willingness \& Ability' and 'Suffering of the Weak and the Environment' which represent the most optimistic and pessimistic view of the future.

\section{Scenario 1: 'Willingness \& Ability'}

The main features of this scenario are: economic prosperity, overall water availability increased through high-tech solutions: (desalination plants, 
construction of Red Sea/Dead Sea conduit), industry and tourism expand, availability of financial resources and an increasing level of public awareness guarantee sustainable development (GLOWA, 2011).

Relative importance of above mentioned criteria are evaluated under this scenario as follow:

Aquifer Storage: A great importance is placed on the preservation of the aquifer

Biodiversity: Sustainability and awareness are important features of this scenario. A higher value is put on the preservation of the biodiversity in the Oasis, and thus higher importance with respect to the chosen abstraction rate.

Income from Agriculture: under the economic prosperity, and high-tech solutions assumed in this scenario a decrease in abstraction rate will have less important impacts on the income from Agriculture. This criterion has less importance with respect to choosing appropriate abstraction rate.

Income from Tourism: Income from tourism under this scenario plays an important role and have higher importance than that from agriculture

Pumping Cost: Economic prosperity is assumed in this scenario, and a decrease in abstraction rate will have less important impacts on this factor

Farmers Acceptance: Under this scenario, public awareness is assumed to be higher, therefore, acceptance level is expected to decrease with decreasing abstraction rates in a less intensity.

Job availability: As industry and tourism expand, decreased job availability as a result of decreased pumping have less impacts on the overall job-availability.

Table 7.6 shows the pairwise comparison of evaluation criteria under this scenario. Table 7.7 shows the preference matrix for criteria comparison, and the eigenvector of the matrix representing the local weights of criteria. Consistency Ratio (CR) of this matrix is $0.07<0.1$ indicating the consistency of our judgments. 
Table 7.6: Pairwise comparison of criteria under 'Willingness \& Ability' scenario

\begin{tabular}{|l|l|l|l|}
\hline \multicolumn{2}{|c|}{ Criteria } & & \\
\hline A & B & More important & Intensity \\
\hline Aquifer storage & Biodiversity & A & 3 \\
\hline Aquifer storage & income from Agriculture & A & 5 \\
\hline Aquifer storage & income from tourism & A & 3 \\
\hline Aquifer storage & Pumping cost & A & 7 \\
\hline Aquifer storage & Job availability & A & 5 \\
\hline Aquifer storage & Farmer acceptance & A & 3 \\
\hline Biodiversity & income from Agriculture & A & 3 \\
\hline Biodiversity & income from tourism & Equal & 1 \\
\hline Biodiversity & Pumping cost & A & 5 \\
\hline Biodiversity & Job availability & A & 3 \\
\hline Biodiversity & Farmer acceptance & A & 3 \\
\hline income from Agriculture & income from tourism & B & 3 \\
\hline income from Agriculture & Pumping cost & A & 3 \\
\hline income from Agriculture & Job availability & A & 1 \\
\hline income from Agriculture & Farmer acceptance & B & 3 \\
\hline income from tourism & Pumping cost & A & 7 \\
\hline income from tourism & Job availability & Equal & 1 \\
\hline income from tourism & Farmer acceptance & Equal & 1 \\
\hline Pumping cost & Job availability & B & 5 \\
\hline Pumping cost & Farmer acceptance & B & 3 \\
\hline Job availability & Farmer acceptance & B & 3 \\
\hline
\end{tabular}

\section{Scenario 2: Suffering of the Weak and the Environment}

The main features of this scenario are: no economic growth - water becomes increasingly expensive - continuous decline in agriculture $\bullet$ infrastructure deterioration in many parts of the region - the poor suffer the consequences absence of financial resources • limited public awareness (GLOWA, 2011). 
Table 7.7: Preference matrix of criteria under 'Willingness \& Ability' scenario

\begin{tabular}{|c|c|c|c|c|c|c|c|c|}
\hline & $\begin{array}{l}\text { Aquifer } \\
\text { Storage }\end{array}$ & Biodiversity & $\begin{array}{l}\text { Income } \\
\text { from } \\
\text { Agriculture }\end{array}$ & $\begin{array}{l}\text { Income } \\
\text { from } \\
\text { Tourism }\end{array}$ & $\begin{array}{l}\text { Pumping } \\
\text { Cost }\end{array}$ & $\begin{array}{l}\text { Job } \\
\text { Availability }\end{array}$ & $\begin{array}{l}\text { Farmer } \\
\text { Acceptance }\end{array}$ & $\begin{array}{l}\text { Eigen- } \\
\text { vector }\end{array}$ \\
\hline $\begin{array}{l}\text { Aquifer } \\
\text { Storage }\end{array}$ & 1 & 3 & 5 & 3 & 7 & 5 & 3 & 0.36 \\
\hline Biodiversity & 0.333 & 1 & 3 & 1 & 5 & 3 & 3 & 0.19 \\
\hline $\begin{array}{l}\text { Income } \\
\text { Agriculture }\end{array}$ & 0.2 & 0.33 & 1 & 0.33 & 3 & 1 & 0.33 & 0.06 \\
\hline $\begin{array}{l}\text { Income } \\
\text { Tourism }\end{array}$ & 0.33 & 1 & 3 & 1 & 7 & 1 & 1 & 0.14 \\
\hline $\begin{array}{l}\text { Pumping } \\
\text { Cost }\end{array}$ & 0.14 & 0.2 & 0.333 & 0.14 & 1 & 0.2 & 0.33 & 0.03 \\
\hline $\begin{array}{l}\text { Job } \\
\text { Availability }\end{array}$ & 0.2 & 0.33 & 1 & 1 & 5 & 1 & 0.33 & 0.08 \\
\hline $\begin{array}{l}\text { Farmer } \\
\text { Acceptance }\end{array}$ & 0.33 & 0.33 & 3 & 1 & 3 & 3 & 1 & 0.13 \\
\hline
\end{tabular}

Relative importance of above mentioned criteria are evaluated under this scenario as follow:

Aquifer Storage: The preservation of the aquifer is important

Biodiversity: A less value is put on the preservation of the biodiversity in the Oasis, as social and economic plays a more important role in choosing the appropriate abstraction rate.

Income from Agriculture: Under the 'Suffering of the Weak and Environment' scenario, where economic situation is suffering, a decrease in abstraction rate will have important impacts on the income from agriculture. This criterion has higher importance with respect to choosing appropriate abstraction rate.

Income from Tourism: Tourism under this scenario is limited, and income from tourism has less importance with respect to the chosen abstraction rate.

Pumping Cost: Under the absence of financial resources, a decrease in abstraction rate will have higher important impacts on this factor 
Farmers Acceptance: Farmers are expected to show less acceptance to decrease in abstraction under this scenario, where public awareness is assumed to be weak

Job Availability: Under this scenario, decreased job availability as a result of decreased pumping have high impacts on the overall availability of jobs, and thus, this criterion plays an important role with respect to the process of decision making.

Table 7.8 shows the pairwise comparison of evaluation criteria under this scenario. Table 7.9 shows the preference matrix for criteria comparison, and the eigenvector of this matrix, which represent the local weights of criteria under the second scenario. Consistency Ratio (CR) of this matrix is $0.07<0.1$ indicating the consistency of our judgments.

Table 7.8: Pairwise comparison of criteria under 'Suffering of the Weak' scenario

\begin{tabular}{|l|l|l|l|}
\hline \multicolumn{2}{|c|}{ Criteria } & & \\
\hline A & B & $\begin{array}{l}\text { More } \\
\text { important }\end{array}$ & Intensity \\
\hline Aquifer storage & Biodiversity & A & 5 \\
\hline Aquifer storage & income from Agriculture & A & 3 \\
\hline Aquifer storage & income from tourism & A & 7 \\
\hline Aquifer storage & Pumping cost & A & 5 \\
\hline Aquifer storage & Job availability & Equal & 1 \\
\hline Aquifer storage & Farmer acceptance & Equal & 1 \\
\hline Biodiversity & income from Agriculture & B & 3 \\
\hline Biodiversity & income from tourism & A & 5 \\
\hline Biodiversity & Pumping cost & A & 3 \\
\hline Biodiversity & Job availability & B & 7 \\
\hline Biodiversity & Farmer acceptance & B & 9 \\
\hline income from Agriculture & income from tourism & A & 9 \\
\hline income from Agriculture & Pumping cost & A & 5 \\
\hline income from Agriculture & Job availability & B & 3 \\
\hline income from Agriculture & Farmer acceptance & B & 3 \\
\hline income from tourism & Pumping cost & B & 3 \\
\hline income from tourism & Job availability & B & 9 \\
\hline income from tourism & Farmer acceptance & B & 9 \\
\hline Pumping cost & Job availability & B & 7 \\
\hline Pumping cost & Farmer acceptance & B & 9 \\
\hline Job availability & Farmer acceptance & Equal & 1 \\
\hline & & & \\
\hline
\end{tabular}


Table 7.9: Preference matrix of criteria under 'Suffering of the Weak and the Environment' scenario

\begin{tabular}{|l|l|l|l|l|l|l|l|l|}
\hline & $\begin{array}{l}\text { Aquifer } \\
\text { storage }\end{array}$ & Biodiversity & $\begin{array}{l}\text { income } \\
\text { from } \\
\text { Agriculture }\end{array}$ & $\begin{array}{l}\text { income } \\
\text { from } \\
\text { tourism }\end{array}$ & $\begin{array}{l}\text { Pumping } \\
\text { cost }\end{array}$ & $\begin{array}{l}\text { Job } \\
\text { availability }\end{array}$ & $\begin{array}{l}\text { Farmer } \\
\text { acceptance }\end{array}$ & $\begin{array}{l}\text { Eigen- } \\
\text { vector }\end{array}$ \\
\hline $\begin{array}{l}\text { Aquifer } \\
\text { storage }\end{array}$ & 1 & 5 & 3 & 7 & 5 & 1 & 1 & $\mathbf{0 . 2 3}$ \\
\hline Biodiversity & 0.20 & 1 & 0.33 & 5 & 3 & 0.14 & 0.11 & $\mathbf{0 . 0 6}$ \\
\hline $\begin{array}{l}\text { income } \\
\text { Agriculture }\end{array}$ & 0.33 & 3 & 1 & 9 & 5 & 0.33 & 0.33 & $\mathbf{0 . 1 2}$ \\
\hline $\begin{array}{l}\text { income } \\
\text { tourism }\end{array}$ & 0.14 & 0.20 & 0.11 & 1 & 0.33 & 0.11 & 0.11 & $\mathbf{0 . 0 2}$ \\
\hline $\begin{array}{l}\text { Pumping } \\
\text { cost }\end{array}$ & 0.20 & 0.33 & 0.20 & 3 & 1 & 0.14 & 0.11 & $\mathbf{0 . 0 4}$ \\
\hline $\begin{array}{l}\text { Job } \\
\text { availability }\end{array}$ & 1 & 7 & 3 & 9 & 7 & 1 & 1 & $\mathbf{0 . 2 6}$ \\
\hline $\begin{array}{l}\text { Farmer } \\
\text { acceptance }\end{array}$ & 1 & 9 & 3 & 9 & 9 & 1 & 1 & $\mathbf{0 . 2 8}$ \\
\hline
\end{tabular}

\subsubsection{Comparing the alternatives with respect to each of the criteria}

Impacts of alternatives on the criteria listed for this study range from tangible and precisely measurable, tangible but difficult to measure to intangible and totally subjective. In making the comparisons, the decision makers can use concrete data about the elements, but they typically use their judgments about the elements' relative meaning and importance (Saaty, 2008).

\section{Aquifer Storage}

Using groundwater flow model the impacts of alternatives on groundwater table by the year 2045 are simulated. Table 7.10 shows expected average groundwater table decline by the year 2045 corresponding to each alternative. Simulation results are used as an indicator to judge on the impacts of alternatives with respect to the preservation of 'Aquifer Storage' and fill out the preference matrix where the less the abstraction rate, the higher the importance of the alternative (Table 7.11). 
Table 7.10: Simulated average groundwater table decline by the year 2045 corresponding to management alternatives

\begin{tabular}{|l|l|l|}
\hline $\begin{array}{l}\text { Pumping strategy } \\
\text { Alternative }\end{array}$ & Description & $\begin{array}{l}\text { Simulated decline in } \\
\text { groundwater table, } \mathbf{~ m}\end{array}$ \\
\hline 1 & $100 \%$ of current abstraction rate & -21 \\
\hline 2 & $80 \%$ of current abstraction rate & -15.5 \\
\hline 3 & $60 \%$ of current abstraction rate & -9.5 \\
\hline 4 & $40 \%$ of current abstraction rate & -3.5 \\
\hline 5 & $30 \%$ of current abstraction rate & 0 \\
\hline
\end{tabular}

\section{Biodiversity}

It is important to prevent groundwater table from declining further in order to preserve the oasis and its biodiversity. For alternatives 1,2 and 3 groundwater table will sink around 21, 16 and 10 meters respectively, and therefore these alternatives have equal impacts with respect to biodiversity. Alternative 1 has the highest importance, and alternative 2 is moderately less important. Table 7.12 shows the preference matrix and calculated local weights of each alternative with respect to 'Biodiversity' criterion.

\section{Income from Agriculture}

This criterion is contrasting to environmental criteria. A higher pumping rate is favored over a lower in order to maximize the income from agricultural sector. Table 7.13 shows the preference matrix and calculated local weights of each alternative with respect to this criterion.

\section{Income from Tourism}

It is difficult to associate a certain level of tourism development with a certain pumping rate. However, those alternatives where the oasis is preserved have high importance with respect to this criterion, as the number of visitors expected to the oasis is higher. Table 7.14 shows the preference matrix and calculated local weights of each alternative with respect to this criterion

Fuel Cost Less pumping is associated with less costs. Additionally, the deeper groundwater level will sink as a result of high pumping rate, the higher fuel costs 
associated with pumping will be. Table 7.15 shows the preference matrix and calculated local weights of each alternative with respect to this criterion.

\section{Job Availability and Farmers Acceptance}

These two social criteria are contrasting to environmental standers. Jobs availability and Farmers acceptance are expected to drop with decrease in abstraction rate. These two criterion have the same Preference matrix (Table 7.16)

Table 7.11: Preference matrix of alternatives with respect to the criterion 'Aquifer Storage'

\begin{tabular}{|c|c|c|c|c|c|c|}
\hline & $\mathbf{1 0 0 \%}$ & $\mathbf{8 0 \%}$ & $\mathbf{6 0 \%}$ & $\mathbf{4 0 \%}$ & $\mathbf{3 0 \%}$ & Eigenvector \\
\hline $\mathbf{1 0 0 \%}$ & 1 & 0.33 & 0.2 & 0.14 & 0.14 & $\mathbf{0 . 0 4}$ \\
\hline $\mathbf{8 0 \%}$ & 3 & 1 & 0.33 & 0.2 & 0.2 & $\mathbf{0 . 0 8}$ \\
\hline $\mathbf{6 0 \%}$ & 5 & 3 & 1 & 0.333 & 0.142 & $\mathbf{0 . 1 3}$ \\
\hline $\mathbf{4 0 \%}$ & 7 & 5 & 3 & 1 & 0.33 & $\mathbf{0 . 2 6}$ \\
\hline $\mathbf{3 0 \%}$ & 7 & 5 & 7 & 3 & 1 & $\mathbf{0 . 4 9}$ \\
\hline
\end{tabular}

Table 7.12: Preference matrix of alternatives with respect to the criterion 'Biodiversity'

\begin{tabular}{|c|c|c|c|c|c|c|}
\hline & $\mathbf{1 0 0 \%}$ & $\mathbf{8 0 \%}$ & $\mathbf{6 0 \%}$ & $\mathbf{4 0 \%}$ & $\mathbf{3 0 \%}$ & Eigenvector \\
\hline $\mathbf{1 0 0 \%}$ & 1 & 1 & 1 & 0.20 & 0.11 & $\mathbf{0 . 0 6}$ \\
\hline $\mathbf{8 0 \%}$ & 1 & 1 & 1 & 0.20 & 0.11 & $\mathbf{0 . 0 6}$ \\
\hline $\mathbf{6 0 \%}$ & 1 & 1 & 1 & 0.20 & 0.11 & $\mathbf{0 . 0 6}$ \\
\hline $\mathbf{4 0 \%}$ & 5 & 5 & 5 & 1 & 0.2 & $\mathbf{0 . 2 3}$ \\
\hline $\mathbf{3 0 \%}$ & 9 & 9 & 9 & 5 & 1 & $\mathbf{0 . 6 0}$ \\
\hline
\end{tabular}

Table 7.13: Preference matrix of alternatives with respect to the criterion 'Income from Agriculture'

\begin{tabular}{|c|c|c|c|c|c|c|}
\hline & $\mathbf{1 0 0 \%}$ & $\mathbf{8 0 \%}$ & $\mathbf{6 0 \%}$ & $\mathbf{4 0 \%}$ & $\mathbf{3 0 \%}$ & Eigenvector \\
\hline $\mathbf{1 0 0 \%}$ & 1 & 3 & 5 & 7 & 7 & 0.50 \\
\hline $\mathbf{8 0 \%}$ & 0.33 & 1 & 3 & 5 & 5 & 0.25 \\
\hline $\mathbf{6 0 \%}$ & 0.20 & 0.33 & 1 & 3 & 3 & 0.13 \\
\hline $\mathbf{4 0 \%}$ & 0.14 & 0.20 & 0.33 & 1 & 3 & 0.07 \\
\hline $\mathbf{3 0 \%}$ & 0.14 & 0.20 & 0.33 & 0.33 & 1 & 0.05 \\
\hline
\end{tabular}


Table 7.14: Preference matrix of alternatives with respect to the criterion 'Income from Tourism'

\begin{tabular}{|c|c|c|c|c|c|c|}
\hline & $\mathbf{1 0 0 \%}$ & $\mathbf{8 0 \%}$ & $\mathbf{6 0 \%}$ & $\mathbf{4 0 \%}$ & $\mathbf{3 0 \%}$ & Eigenvector \\
\hline $\mathbf{1 0 0 \%}$ & 1 & 1 & 1 & 0.2 & 0.11 & $\mathbf{0 . 0 6}$ \\
\hline $\mathbf{8 0 \%}$ & 1 & 1 & 1 & 0.2 & 0.11 & $\mathbf{0 . 0 6}$ \\
\hline $\mathbf{6 0 \%}$ & 1 & 1 & 1 & 0.2 & 0.11 & $\mathbf{0 . 0 6}$ \\
\hline $\mathbf{4 0 \%}$ & 5 & 5 & 5 & 1 & 0.2 & $\mathbf{0 . 2 3}$ \\
\hline $\mathbf{3 0 \%}$ & 9 & 9 & 9 & 5 & 1 & $\mathbf{0 . 6 0}$ \\
\hline
\end{tabular}

Table 7.15: Preference matrix of alternatives with respect to the criterion 'Fuel Cost'

\begin{tabular}{|c|c|c|c|c|c|c|}
\hline & $\mathbf{1 0 0 \%}$ & $\mathbf{8 0 \%}$ & $\mathbf{6 0 \%}$ & $\mathbf{4 0 \%}$ & $\mathbf{3 0 \%}$ & Eigenvector \\
\hline $\mathbf{1 0 0 \%}$ & 1 & 0.33 & 0.2 & 0.14 & 0.14 & $\mathbf{0 . 0 4}$ \\
\hline $\mathbf{8 0 \%}$ & 3 & 1 & 0.33 & 0.2 & 0.2 & $\mathbf{0 . 0 8}$ \\
\hline $\mathbf{6 0 \%}$ & 5 & 3 & 1 & 0.33 & 0.14 & $\mathbf{0 . 1 3}$ \\
\hline $\mathbf{4 0 \%}$ & 7 & 5 & 3 & 1 & 0.33 & $\mathbf{0 . 2 6}$ \\
\hline $\mathbf{3 0 \%}$ & 7 & 5 & 7 & 3 & 1 & $\mathbf{0 . 4 9}$ \\
\hline
\end{tabular}

Table 7.16: Preference matrix of alternatives with respect to the criteria 'Job Availability' and 'Farmers Acceptance'

\begin{tabular}{|c|c|c|c|c|c|c|}
\hline & $\mathbf{1 0 0 \%}$ & $\mathbf{8 0 \%}$ & $\mathbf{6 0 \%}$ & $\mathbf{4 0 \%}$ & $\mathbf{3 0 \%}$ & Eigenvector \\
\hline $\mathbf{1 0 0 \%}$ & 1 & 3 & 5 & 7 & 7 & $\mathbf{0 . 5}$ \\
\hline $\mathbf{8 0 \%}$ & 0.33 & 1 & 3 & 5 & 5 & $\mathbf{0 . 2 5}$ \\
\hline $\mathbf{6 0 \%}$ & 0.2 & 0.33 & 1 & 3 & 3 & $\mathbf{0 . 1 3}$ \\
\hline $\mathbf{4 0 \%}$ & 0.14 & 0.20 & 0.33 & 1 & 3 & $\mathbf{0 . 0 7}$ \\
\hline $\mathbf{3 0 \%}$ & 0.14 & 0.20 & 0.33 & 0.33 & 1 & $\mathbf{0 . 0 5}$ \\
\hline
\end{tabular}

\subsubsection{Making the decision}

At the end, the global weights of alternatives are arranged and combined to get (Total) priority that describe how much each alternative fits with respective to the 
mentioned judgments (criteria). Global and total priorities of alternatives for scenarios 1 and 2 are shown in Table 7.17 and Table 7.18 respectively.

For Scenario 1 'Willingness \& Ability' an abstraction rate of $30 \%$ the current one (the safe yield of the aquifer) with a global priority of 0.402 , is the alternative that contributes the most to the goal of choosing the abstraction rate. The other alternatives have considerably less priority than that.

For the second Scenario 'Suffering of the Weak and the Environment' keeping the current pumping rate has a global priority of 0.34 , and it is the alternative that contributes the most to the goal of choosing the abstraction rate in the basin. The safe yield option is the second priority with global weight of 0.21 .

The results highlight the importance of integrate the socio-economic aspects in the process of decision making, and shows the influence of the socio-economic situation on our decision.

Table 7.17: Global and total priorities of alternatives under 'Willingness \& Ability' scenario

\begin{tabular}{|l|l|l|l|l|l|l|l|l|}
\hline & \multicolumn{2}{|l|}{ Aquifer Storage } & \multicolumn{2}{l}{ Biodiversity } & \multicolumn{2}{l|}{$\begin{array}{l}\text { Income from } \\
\text { Agriculture }\end{array}$} & \multicolumn{2}{l|}{$\begin{array}{l}\text { Income from } \\
\text { Tourism }\end{array}$} \\
\hline Alternative & Weight & $\begin{array}{l}\text { Global } \\
\text { weight }\end{array}$ & Weight & $\begin{array}{l}\text { Global } \\
\text { weight }\end{array}$ & Weight & $\begin{array}{l}\text { Global } \\
\text { weight }\end{array}$ & Weight & $\begin{array}{l}\text { Global } \\
\text { weight }\end{array}$ \\
\hline $\mathbf{1 0 0 \%}$ & 0.04 & 0.014 & 0.06 & 0.01 & 0.50 & 0.03 & 0.06 & 0.008 \\
\hline $\mathbf{8 0 \%}$ & 0.08 & 0.027 & 0.06 & 0.01 & 0.25 & 0.02 & 0.06 & 0.008 \\
\hline $\mathbf{6 0 \%}$ & 0.13 & 0.047 & 0.06 & 0.01 & 0.13 & 0.01 & 0.06 & 0.008 \\
\hline $\mathbf{4 0 \%}$ & 0.26 & 0.093 & 0.23 & 0.044 & 0.07 & 0.00 & 0.23 & 0.033 \\
\hline $\mathbf{3 0 \%}$ & 0.49 & 0.175 & 0.60 & 0.113 & 0.05 & 0.00 & 0.60 & 0.087 \\
\hline
\end{tabular}

\begin{tabular}{|l|l|l|l|l|l|l|l|}
\hline & \multicolumn{3}{|l|}{ Pumping Costs } & \multicolumn{2}{l|}{ Job Availability } & \multicolumn{2}{l|}{$\begin{array}{l}\text { Farmer } \\
\text { Acceptance }\end{array}$} \\
\hline Alternative & Weight & $\begin{array}{l}\text { Global } \\
\text { weight }\end{array}$ & Weight & $\begin{array}{l}\text { Global } \\
\text { weight }\end{array}$ & Weight & $\begin{array}{l}\text { Global } \\
\text { weight }\end{array}$ & Total \\
\hline $\mathbf{1 0 0 \%}$ & 0.03 & 0.001 & 0.50 & 0.043 & 0.50 & 0.066 & $\mathbf{0 . 1 7 3}$ \\
\hline $\mathbf{8 0 \%}$ & 0.07 & 0.002 & 0.25 & 0.022 & 0.25 & 0.034 & $\mathbf{0 . 1 1 9}$ \\
\hline $\mathbf{6 0 \%}$ & 0.13 & 0.004 & 0.12 & 0.011 & 0.12 & 0.016 & $\mathbf{0 . 1 0 5}$ \\
\hline $\mathbf{4 0 \%}$ & 0.26 & 0.008 & 0.07 & 0.006 & 0.07 & 0.010 & $\mathbf{0 . 2 0 0}$ \\
\hline $\mathbf{3 0 \%}$ & 0.49 & 0.015 & 0.05 & 0.004 & 0.05 & 0.006 & $\mathbf{0 . 4 0 2}$ \\
\hline
\end{tabular}


Table 7.18: Global and total priorities of alternatives under 'Suffering of the Weak and the Environment' scenario

\begin{tabular}{|l|l|l|l|l|l|l|l|l|l|}
\hline & \multicolumn{2}{|l|}{ Aquifer Storage } & \multicolumn{2}{l|}{ Biodiversity } & \multicolumn{2}{l|}{$\begin{array}{l}\text { Income from } \\
\text { Agriculture }\end{array}$} & \multicolumn{2}{l|}{$\begin{array}{l}\text { Income from } \\
\text { Tourism }\end{array}$} \\
\hline Alternative & Weight & $\begin{array}{l}\text { Global } \\
\text { weight }\end{array}$ & Weight & $\begin{array}{l}\text { Global } \\
\text { weight }\end{array}$ & weight & $\begin{array}{l}\text { Global } \\
\text { weight }\end{array}$ & Weight & $\begin{array}{l}\text { Global } \\
\text { weight }\end{array}$ \\
\hline $\mathbf{1 0 0 \%}$ & 0.04 & 0.008 & 0.06 & 0.003 & 0.50 & 0.06 & 0.06 & 0.001 \\
\hline $\mathbf{8 0 \%}$ & 0.08 & 0.017 & 0.06 & 0.003 & 0.25 & 0.03 & 0.06 & 0.001 \\
\hline $\mathbf{6 0 \%}$ & 0.13 & 0.03 & 0.06 & 0.003 & 0.13 & 0.02 & 0.06 & 0.001 \\
\hline $\mathbf{4 0 \%}$ & 0.26 & 0.06 & 0.23 & 0.013 & 0.07 & 0.01 & 0.23 & 0.004 \\
\hline $\mathbf{3 0 \%}$ & 0.49 & 0.11 & 0.60 & 0.034 & 0.05 & 0.01 & 0.60 & 0.012 \\
\hline
\end{tabular}

\begin{tabular}{|l|l|l|l|l|l|l|l|}
\hline & \multicolumn{2}{|l|}{ Pumping Cost } & \multicolumn{2}{l|}{ Job Availability } & \multicolumn{2}{l|}{$\begin{array}{l}\text { Farmer } \\
\text { Acceptance }\end{array}$} & \\
\hline Alternative & Weight & $\begin{array}{l}\text { Global } \\
\text { weight }\end{array}$ & Weight & $\begin{array}{l}\text { Global } \\
\text { weight }\end{array}$ & weight & $\begin{array}{l}\text { Global } \\
\text { weight }\end{array}$ & Total \\
\hline $\mathbf{1 0 0 \%}$ & 0.04 & 0.001 & 0.50 & 0.128 & 0.50 & 0.138 & $\mathbf{0 . 3 4}$ \\
\hline $\mathbf{8 0 \%}$ & 0.08 & 0.002 & 0.25 & 0.065 & 0.25 & 0.070 & $\mathbf{0 . 1 9}$ \\
\hline $\mathbf{6 0 \%}$ & 0.13 & 0.004 & 0.13 & 0.032 & 0.13 & 0.034 & $\mathbf{0 . 1 2}$ \\
\hline $\mathbf{4 0 \%}$ & 0.26 & 0.009 & 0.07 & 0.019 & 0.07 & 0.020 & $\mathbf{0 . 1 4}$ \\
\hline $\mathbf{3 0 \%}$ & 0.49 & 0.017 & 0.05 & 0.011 & 0.05 & 0.012 & $\mathbf{0 . 2 1}$ \\
\hline
\end{tabular}




\section{Conclusion}

\subsection{Thesis aspects}

The focus of this research is the analysis of potential management solutions for the water problem in arid and semiarid regions with emphasis on groundwater management and application of Managed Aquifer Recharge. A case-study was executed in Azraq basin, where groundwater flow model was built and calibrated. Several applications were conducted including MAR sites selection and determination of aquifer Safe Yield. Scenarios of climate change, different pumping rates and MAR were also tested. A multi-criteria analysis was applied in the decision making regarding suitable abstraction rate in the basin under conflicting environmental and socio-economic criteria.

\subsection{Data acquisition and analysis}

Time series data on rainfall, climatological data, springs discharge, observed level of groundwater table were collected from the Ministry of Water and Irrigation in Jordan, along with data on the basin's physical properties.

Time series data on rainfall were incomplete and a quality check was necessary. A combination between the Ratio and Quadrant method was used to estimate missing data at rainfall stations north of the basin where the intensity of rainfall stations is relatively high. Good correlation was obtained between measured rainfall and calculated values using this method.

The intensity of station in the south of the basin is low, and the difference between average annual precipitation at these stations is big, therefore, correlation method was used to estimate missing data.

The estimation of areal precipitation in the basin was done using the Thiessen polygon method, and rainfall volume was calculated on a wadi-basis. The amount of rainfall range between 290-2100 MCM/year with an average value of 1050 $\mathrm{MCM} / \mathrm{year}$. The records show a big variance and high inter-annual variability.

As the Azraq basin is not gauged the Curve Number method is used to calculate the runoff in the different wadis in the basin, where a $\mathrm{CN}$ is chosen based on the 
characteristics of the wadi (landuse, soil type). The surface runoff volume in the basin range between 1-126 MCM/year with an average value of $53 \mathrm{MCM} /$ year.

Climatological records obtained from climate station F0009 in the basin were used to calculate daily potential evaporation using Penman-Monteith-FAO equation.

Records of solar radiation Rs were highly interrupted and a lot of readings were missing, therefore, on days when shortwave radiation reading is missing measured duration of sunshine along with minimum and maximum temperature were used to calculate solar radiation. Long term average potential EVT range between 1.8 $\mathrm{mm} /$ day in December to $10 \mathrm{~mm} /$ day in June.

Groundwater recharge was estimated using the water budget method on a daily basis. The amount of groundwater recharge in the basin range between $4-133$ $\mathrm{MCM} / \mathrm{year}$ with an average of $39.9 \mathrm{MCM} / \mathrm{year}$.

groundwater recharge in the different wadis constitutes between $1.3 \%$ and $6.7 \%$ of rainfall which is in accordance with groundwater recharge estimations in Jordan

\subsection{Development of groundwater flow model}

Several models have been built and calibrated for Azraq basin. Model domains have been chosen within the political borders of Jordan excluding main recharge area in the Syrian part north of the basin. A coarse time step of one year was used by all studies due to the quality of abstraction data available as yearly lump-sums at the Ministry of Water and Irrigation, Jordan.

In this study, a model is built and calibrated for the Azraq basin using the modular three-dimensional finite difference groundwater flow code MODFLOW. A Larger model domain is adopted which includes recharge area in the north. A stress period and time step of one month were chosen. The groundwater system in the study area is modelled as 3-layered-system representing the shallow and middle aquifer systems and the aquitard separating them.

Model calibration is performed to steady-state and transient state data set. The distribution of measured heads in the basin prior to any substantial pumping occurring was used to calibrate hydraulic conductivity in the steady-state model. Transient calibration was done for two periods (1960-1980) where abstraction from the basin is neglected, and (1980-2012) where pumping started and increased substantially. Springs discharge and data on fluctuation of groundwater table at 
monitoring wells in the basin were used to adjust values of hydraulic conductivity and calibrate aquifer specific yield.

Calibrated values of $\mathrm{K}$ of the basalt and the B45 aquifers are 15 and $1.2 \mathrm{~m} /$ day respectively indicating the higher conductivity of the Basalt. Calibrated values of specific yield of Basalt and B45 aquifers are 0.002 and 0.02 respectively.

Good match between simulated and measured hydrographs for water table decline in monitoring wells was obtained. The model was able to simulate water fluctuation at monitoring wells that exist in the carbonate B45 aquifer. However, simulation results for observation well F1280 located in the highly fractured Basalt aquifer show no seasonal fluctuations in contrast to measured values, indicating that water table fluctuation is governed by the flow through fractures and preferential flow paths in the basalt which cannot be well represented using the one-continuum modeling approach.Reasonably good match between simulated and measured springs discharge was obtained. The model couldn't accurately simulate the fluctuation of discharge and the dry-out as the flow occurs through the highly karstified zone around the springs.

\subsection{MAR suitability map}

Many literatures exist on the subject of MAR with a focus on MAR-site selection. A qualitative method is applied by the majority of studies using GIS techniques where; hydrogeological factors seem to be investigated to a limited extent, variable criteria are applied for the definition of suitability ranges of factors and the characteristics of the water source for artificial recharge are not analyzed.

In this study, a quantitative method for the delineation of suitable sites for MAR based on sub-surface (hydrogeological) criteria was introduced where numerical groundwater modeling is applied to simulate groundwater mounds beneath hypothetical infiltration basins.

For the simulations, regional values of hydraulic conductivity and specific yield are used, and a uniform structure's design and infiltration rate are applied. Scenarios on the volume of infiltrated water are based on the characteristics of surface runoff in the basin.

Simulation results are employed to calibrate an empirical equation that calculates the height of groundwater mound as a function of aquifer transmissivity and 
volume of infiltrated water. The calibrated equation is applied in GIS to spatially evaluate the response of groundwater table to artificial recharge and delineate suitable MAR sites.

Sensitivity analysis was conducted where $\mathrm{K}$ and Sy were reduced $50 \%$ and the resulting change in groundwater mound was realized. The results show that the height of groundwater mound has increased between $30 \%$ and $50 \%$ as a result of reducing horizontal and vertical hydraulic conductivity by $50 \%$, and increased between $1-7 \%$ as result of $50 \%$ decrease in Sy value.

Suitability maps were generated for two scenarios of MAR structure's collection capacity (based on the $50^{\text {th }}$ and $80^{\text {th }}$ percentile of monthly runoff in the respective wadi), and 2 scenarios of hydraulic conductivity (calibrated and $50 \%$ of calibrated values).

Suitability maps show the ability to implement MAR over a wide area of northern wadis, which coincide with the Basalt aquifer, for all scenarios of $\mathrm{K}$ and collection capacity. The suitability of sites for MAR in wadis over the B45 aquifer is less, and it changes considerably depending on MAR collection's capacity and K scenario, which shows the importance of investigating hydraulic conductivity and characteristics of water resource in MAR sites selection.

For the generation of MAR suitability map based on surface characteristics, a decision system is proposed for combining thematic maps, where a suitability degree is assigned to a set of characteristics, so that the suitability of each class of each factor is judged in combination with other factors' classes.

Three surface factors were investigated in the basin for their suitability for MAR implementation; slope, soil texture and soil thickness, to generate a MAR suitability map in terms of surface factors, and combine it with suitability map in terms of subsurface characteristics. Based on suitability maps three MAR dams were proposed in the basin.

\subsection{Assessing management strategies in the basin}

Aquifer's behavior under different scenarios of pumping rates, MAR and possible shifts in groundwater recharge was simulated, and aquifer's safe yield was 
determined. Simulation results showed that average groundwater table decline will be $20 \mathrm{~m}$ in the year 2045 if the current pumping patters continue.

The safe yield of the aquifer, defined as the amount of water that can be pumped out with no further decline of groundwater table over the coming years, was found to be $30 \%$ of the average pumping rate in recent years, which indicates that the basin is being largely exploited beyond its capacity.

Simulation results show that $25 \%$ and $50 \%$ decrease in groundwater recharge for the next 30 years will have negligible impacts on the groundwater table level in the aquifer which indicate that the groundwater in the basin is fossil water, and the aquifer can be considered as a non-renewable resource.

The results show that the application of MAR in the basin doesn't contribute greatly to increasing the safe yield. Under MAR scenario where the capacity of MAR dam is designed based on the $50^{\text {th }}$ and $80^{\text {th }}$ percentiles of monthly surface runoff, groundwater head will increase 0.7 and $1 \mathrm{~m}$ by the year 2045 respectively.

In order to investigate the extent to which management solutions are accepted socially and economically, Analytic Hierarchy Process (AHP) was applied to analyze proposed management alternatives (different decreased pumping rates) under conflicting environmental and socio-economic criteria.

Active stakeholders in the area should be involved in the process of decision making. As a part of GLOWA project, stakeholders and scientists were involved in preparing 4 scenarios describing various alternative socio-economic changes that may take place in the region, including potential economic developments and demographic issues.

Two of those four scenarios; 'Willingness \& Ability' and 'Suffering of the Weak and the Environment' which represent the most optimistic and pessimistic view of the future, were used for comparing the importance of criteria with respect to the decision on abstraction rate from Azraq basin.

Under scenario 'Willingness \& Ability' an abstraction rate of $30 \%$ of the current one (the safe yield of the aquifer) was found to be the alternative that contributes the most to the goal of choosing the abstraction rate. For the second scenario 'Suffering of the Weak and the Environment' keeping the current pumping rate 
was the alternative that contributes the most to the goal of choosing the abstraction rate in the basin. The safe yield option was found to be the second priority.

The results highlight the importance of integrating the socio-economic aspects in the process of decision making, and shows the influence of the socio-economic situation on our decision.

\subsection{Recommendations and perspectives}

It is recommended to conduct runoff measurements in the wadis of the basin which would enable the application of calibrated models for the simulation of surface runoff and groundwater recharge and obtain more accurate estimation of these two components.

The number of monitoring wells in the basin is very small compared to its size, and an updated contour map of groundwater level is not available. It is strongly recommended to install more monitoring wells, and to conduct vast measurements to generate an updated contour map of groundwater level, which would help better calibrate and validate our groundwater flow model.

Due to the existence of faults and fractures in the basalt and the karstification system in the carbonate aquifer, a double continuum approach could be applied where two equivalent models each has its own $\mathrm{K}$ and storage are interacting with each other. This helps add importance to the model where flow in fractures is accounted for, and seasonal fluctuation in springs discharge and groundwater head is better simulated.

Derived equations that calculate groundwater mound height based on aquifer transmissivity and volume of infiltrated water can be used elsewhere for aquifers with similar hydrogeological characteristics (vertical $\mathrm{K}$, Sy) to generate MAR suitability maps. More simulations could be conducted under more scenarios of Sy and vertical hydraulic conductivity to come up with a guideline where water managers could choose suitable equations based on aquifer characteristics in their areas.

The generated MAR suitability maps are considered as a first step for the delineation of suitable sites for MAR. Site-specific analysis (infiltration and 
pumping test, detection of impervious layers in the vadose zone) are still necessary before making the final decision regarding the suitability of a site.

The decision if MAR's capacity should be designed to capture the $50^{\text {th }}, 80^{\text {th }}$ or any other percentile of monthly surface runoff has some economic considerations. Taking into account the high variability of storm water in arid areas, a collection capacity of MAR structure based on a high percentile has an inflated cost per water-unit. Other than economic constraint, suitability of sites to accommodate large amount of water could also influence the decision. The generated suitability maps of the study region for different scenarios of water collection can be used by managers when making the decision on the scale of MAR structure when storm water is highly variable.

Water resources management is done under conflicting criteria, and active stakeholders in the area should be involved in the process of decision making. Meetings could be organized with active stakeholders in Azraq basin in order to engage them in setting relative importance of the different evaluation criteria. Additionally, detailed analyses of pumping costs and income loss associated with decreased abstraction rates in the basin can be conducted to support the judgments used to build the AHP model. 


\section{List of References}

Abadie, J. and Carpentier, J. (1969): Generalization of the Wolfe reduced gradient method to the case of nonlinear constraints. In Optimization (R. Fletcher, Ed.), Academic press, New York, Chapter 4, USA.

Abdulla, F.A., Al-Khatib, M.A., Al-Ghazzawi, Z.D. (2000): Development of groundwater modeling for the Azraq Basin, Jordan. Environmental Geology 40 (1-2).

Abu-El-Sha'r, W. and Hatamleh, R. (2007): Using Modflow and MT3D Groundwater Flow and Transport Models as a Management Tool for the Azraq Groundwater System. Jordan Journal of Civil Engineering, Volume 1, No. 2

Abu-Taleb, M. F. (2003): Recharge of groundwater through multi-stage reservoirs in a desert basin. Environmental Geology, 44, 379-390.

Abu-Taleb, M.F. (1999): "The use of infiltration field tests for groundwater artificial recharge." Environmental Geology 37(1): 64-71.

Al Mahamid, J. (2005): Integration of Water Resources of the Upper Aquifer in Amman-Zarqa Basin Based on Mathematical Modeling and GIS-Jordan. Freiberg Online Geology (FOG),VOL 12.

Al-Adamat, R., Diabat, A. and Shatnawi, G. (2010): Combining GIS with multicriteria decision making for siting water harvesting ponds in Northern Jordan Journal of Arid Environments, 74, 1471-1477.

Al-Assa'd, T. A. and Abdulla, F. A. (2010): Artificial groundwater recharge to a semiarid basin: case study of Mujib aquifer, Jordan, Environ Earth Sci, 60:845-859.

Al-Kharabsheh, A. (1995): Possibilities of artificial groundwater recharge in the Azraq Basin: potential surface water utilization of five representative catchment areas (Jordan). $\mathrm{PhD}$ Dissertation, Selbstverlag des Lehr- u. Forschungsbereichs Hydrologie und Umwelt am Inst. für Geologie.

Al-Kharabsheh, A. (2000): Groundwater modelling and long-term management of the Azraq basin as an example of arid area conditions (Jordan), Journal of Arid Environments 44: 143-153.

Allen, R G., Pereira, L S., Raes, D. and Smith, M. (1998): Crop evapotranspiration Guidelines for computing crop water requirements - FAO Irrigation and drainage paper 56. FAO - Food and Agriculture Organization of the United Nations, Rome. 
Alraggad, M. and Jasem, H. (2010): Managed Aquifer Recharge (MAR) through Surface Infiltration in the Azraq Basin/Jordan, J. Water Resource and Protection, 2, 1057-1070.

Anane, M., Bouziri, L., Limam, A., and Jellali, S. (2012): Ranking suitable sites for irrigation with reclaimed water in the Abeul-Hammamet region (Tunisia) using GIS and AHP-multicriteria decision analysis. Resources, Conservation and Recycling. 65: 36-46.

Anbazhagan, S., Ramasamy, S. M., and Das Gupta, S. (2005): Remote sensing and GIS for artificial recharge study, runoff estimation and planning in Ayyar basin, Tamil Nadu, India. Environmental Geology, 48, 158-170.

Anderson, M. P. and Woessner, W. W. (1992): Applied groundwater modeling (Simulation of flow and advective transport). Academic Press, Inc., London.

Apel, M. (2006): From 3d geomodeling systems towards 3d geoscience information systems, data model, query functionality and data management. Computers \& Geosciences, 32 (2), 222-229.

Arabtech Consulting Engineering (1994): Groundwater investigation in the Azraq basin. Unpublished report, Ministry of Water and Irrigation, Water Authority, Jordan.

Ayed, R. (1986): Surface water resources in Azraq Basin. Amman, Water Authority, The Hashemite Kingdom of Jordan.

Bhuiyan, C. (2015): An approach towards site selection for water banking in unconfined aquifers through artificial recharge. Journal of Hydrology 523, 465-474.

Borgstedt, A., Margane, A., Subah, A., Hajali, Z., Almomani, T., Khalifa, N., Jaber, A. and Hamdan, I. (2007): Delineation of groundwater protection zones for the Corridor wellfield. Groundwater Resources Management. Technical cooperation. Project No: 2005.2110.4. Amman. Technical Report No 8: 173 p.

Bosch, D., Pease, J., Wolfe, M.L., Zobel C., Osorio J., Cobb T.D., and Evanylo, G. (2012): Community Decisions: Stakeholder focused watershed planning. Journal of Environmental Management. 112: 226-232.

Bouwer, H. (2002), Artificial recharge of groundwater: hydrogeology and engineering, Hydrogeology Journal (2002) 10:121-142.

Chenini, I. and Ben Mammou, A. (2010) Groundwater recharge study in arid region: An approach using GIS techniques and numerical modeling, Computers \& Geosciences 36 (2010) 801-817. 
Cosby, B.J., Homberger, G.M., Clapp, R.B. and Ginn, T.R. (1984): "A statistical exploration of the relationships of soil moisture characteristics to the physical properties of soils." Water Resour Res. 20(6): 682-690.

Darmame, K. (2004): Gestion de la rareté: Le service d'eau potable d'Amman entre la gestion publique et privée. Amman: IWMI.

Delgado-Galván, X., Pérez-García, R., Izquierdo, J., and Mora-Rodríguez, J. (2010): An analytic hierarchy process for assessing externalities in water leakage manage-ment. Mathematical and Computer Modelling. 52: 1194-1202.

Doherty, J. (2001): PEST-ASP upgrade notes. Watermark Computing. Australia.

Dottridge, J. and Jaber, N. A. (1999): Groundwater resources and quality in northeastern Jordan: Safe yield and sustainability. Applied Geography, 19, 313-323.

El-Naqa, A., Al-Momani, M., Kilani, S. and Hammouri, N. (2007): Groundwater Deterioration of Shallow Groundwater Aquifers Due to Overexploitation in Northeast Jordan. CLEAN - Soil, Air, Water 35(2): 156-166.

Freeze R.A. and Cherry, J.A. (1979): Groundwater. Prentice Hall, New Jersey, pp 364367

Gale, L. (2005): Strategies for Managed Aquifer Recharge (MAR) in semi-arid areas, UNESCO’s International Hydrological Programme (IHP).

Gaur, S., Chahar, B. R., and Graillot, D. (2011): Combined use of groundwater modeling and potential zone analysis for management of groundwater. International Journal of Applied Earth Observation and Geoinformation, 13(1), 127-139.

GEF (1993): Conservation of the Dana and Azraq Oasis project. New York: Global Environment Facility (GEF).

Ghayoumian, J., Ghermezcheshme, B., Feiznia, S. and Noroozi, A. A. (2005): Integrating GIS and DSS for identification of suitable areas for artificial recharge, case study Meimeh Basin, Isfahan, Iran, Environ Geol, 47: 493-500.

Ghayoumian, J., Saravi, M. M., Feiznia, S., Nouri, B. A. and Malekian, A. (2007): Application of GIS techniques to determine areas most suitable for artificial groundwater recharge in a coastal aquifer in southern Iran. Journal of Asian Earth Sciences,30, 364374.

Glover, R.E. (1961): Mathematical Derivations as Pertains to Groundwater Recharge. Fort Collins, Colorado: Agriculture Research Services, USDA. 
GLOWA (2011): Future management of the Jordan river basin's water and land resources under climate change, a Scenario Analysis - Summary Report. 201.

Goode, J., Senior, L., Subah, A., and Jaber, A. (2013): Groundwater level trends and forecasts, and salinity trends in the Azraq, dead sea, Hammad, Groundwater basins, Jordan. Open-File Report, U.S. Department of the Interior. U.S. Geological Survey.

GWP (2000): Integrated Water Resources Management. Global Water partnership (GWP), Technical Advisory Committee Background (TAZ) Paper 4. Stockholm, Sweden.

Hantush, M.S. (1967): Growth and decay of groundwater-mounds in response to uniform percolation. Water Resources Research 3, no. 1: 227-234.

Heisig, P.M., and K.R. Prince (1993): Characteristics of a groundwater plume derived from artificial recharge with reclaimed wastewater at East Meadow, Long Island, New York.Water-Resources Investigations Report 91-4118. U.S. Geological Survey.

Hill, M.C., Banta, E. R., Harbaugh, A. W. and Anderman E. R. (2000): MODFLOW2000.The U.S. Geological Survey modular ground-water model - User guide to the observation, sensitivity, and parameter-estimation processes and three postprocessing programs, U. S. Geological Survey, Open-file report 00-184.

Hobler, M., Margane, A., Almomani, M. and Subah, A. (2001): Groundwater resources of northern Jordan Volume-4 contribution to the hydrogeology of Northern Jordan. BGRWAJ technical cooperation project.

Huber, M. (2010): Development of a WEAP-Model for Azraq Basin, Jordan, Part 1, Hydrology, Amman, MWI and GIZ, Int. J. Climatol. 31: 1377-1388

Ilangkumaran, M., Sasirekha , V., Anojkumar, L., Sakthivel, G., Boopathi Raja, M., RubanSundara Raj, T., Siddhartha, C.N.S., Nizamuddin, P., and Praveen Kumar, S. (2013): Optimization of wastewater treatment technology selection using hybrid MCDM. Management of Environmental Quality: An International Journal. 24: 619-641.

Intergovernmental Panel on Climate Change (http://ipcc-data.org)

Kalbar, P.P., Karmakar, S., and Asolekar, S.R. (2013): The influence of expert opinions on the selection of wastewater treatment alter-natives: A group decision-making approach. Journal of Environmental Management. 128: 844-851. 
Kumar, A. and Dua, A. (2009): Water Quality Index for Assessment of Water Quality of river Ravi at Madhopur (India), Global Journal of Environmental Sciences, VOL. 8, NO. $1,49-57$.

Lee, T.C., Williams, A.E. and Wang. C. (1992): An artificial recharge experiment in San Jacinto basin, Riverside, southern California. Journal of Hydrology 140, no. 1-4: 235259.

Liu, C.W., Chou, Y.L., Lin, S. T., Lin, G.J., Jang, C. S. (2010): Management of High Groundwater Level Aquifer in the Taipei Basin. Water Resour Manage. DOI 10.1007/s11269-010-9617-9

Mahmoud, S. H., Alazba, A. A. and Amin, M. T (2014): Identification of Potential Sites for Groundwater Recharge Using a GIS-Based Decision Support System in Jazan Region-Saudi Arabia Water Resour Manage. 28:3319-3340.

Margane, A., Hobler, M., Al-Momani, M. and Subah, A. (2002): Contributions to the hydrogeology of Northern and Central Jordan. Bundesanstalt fuer Geowissenschaften und Rohstoffe und Staatliche Geologische in der Bundesrepublik Deutschland, Stuttgart. ISBN 3-510-95890-X, 52 p.

McDonald, M.G. and Harbaugh, A.W. (1988): MODFLOW. A modular threedimensional finite difference ground-water flow model. U. S. Geological Survey. Openfile report 83-875.

Meinzer, OE. (1923): Outline of ground-water hydrology with definitions. U.S. Geological Survey Water-Supply Paper 494

Mesnil, A. and Habjoka, N. (2012): The Azraq Dilemma. Past, Present and Future Groundwater Management. German - Jordanian Programme "Management of Water Resources". Amman, Deutsche Gesellschaft für Internationale Zusammenarbeit (GIZ), Jordanian Ministry of Water and Irrigation (MWI): 64 p.

Messing, I. (1998): "A simple practical evaporimeter: Comparison of Andersson evaporimeter with class a pan, piche atmometer, and penman evaporation." Arid Soil Research and Rehabilitation. 12(3): 275-290.

Millennium Ecosystem Assessment (2005): Ecosystems and Human Wellbeing: Wetlands and Water Synthesis, World Resources Institute, Washington, DC.

Ministry of Agriculture (1993): The soils of Jordan level1 - Reconnaisance Soil Survey: Vol.3. Main Report 1993. - National Soil Map and Landuse Project. Ministry of Agriculture,Amman. 
Ministry of Environment (MOE) and UNDP (2009): Jordan's Second National Communication (Jordan SNC) to the United Nations Framework Convention on Climate Change, Amman, Jordan.

MWI and GTZ (2004): NWMP, Water Resource Planning Support Project. The Hashemite Kingdom of Jordan.

MWI and GTZ (2008): National Water Resources Plan (NWMP), Groundwater Recourses. The Hashemite Kingdom of Jordan.

MWI and GTZ (2003): NWMP, Surface Water Resources. Jordan. The Hashemite Kingdom of Jordan.

Pavelic, P. (2005): Use of Isotopes and geochemical techniques in the study of artificial recharge in groundwater: Advice on design and monitoring to counterparts in Jordan, Syria and Yemen. IAEA Technical Co-Operation Expert Mission, 18 to 28 September. RAS/8/103/01.CSIRO Land and Water. Adelaide, Australia.

Rahman, M. A., Rusteberg, B., Gogu, R.C., Ferreira, L. and Sauter, M. (2012): A new spatial multi-criteria decision support tool for site selection for implementation of managed aquifer recharge, Journal of Envirnmental Management 99, 61e75.

Rahman, M.A., Rusteberg, B., Uddin, M.S., Lutz, A., Abu Saada, M. and Sauter, M. (2013): An integrated study of spatial multicriteria analysis and mathematical modelling for managed aquifer recharge site suitability mapping and site ranking at Northern Gaza coastal aquiferJournal of Environmental Management 124 (2013) 25e39.

Rapp, M. (2008): Evaluation of Potential Sites for Managed Aquifer Recharge via Surface Infiltration in NW-Jordan. Unpublished Diploma Thesis, Department of Applied Geology (AGK), University of Karlsruhe (TH), Karlsruhe, Germany.

Roseta-Palman, C., Iglesiasy, E. and Koppl-Turynaz, M. (2015): Illegal groundwater pumping, Contributed paper for the 59th AARES Annual Conference, Rotorua, New Zealand.

RWC (2009): Royal Water Committee, Water for life, Jordan's Water Strategy 20082022.

Saaty, T. L. (1980): The Analytic Hierarchy Process, McGraw-Hill, New York.

Saaty, T. L. (2008): Relative Measurement and its Generalization in Decision Making: Why Pairwise Comparisons are Central in Mathematics for the Measurement of Intangible Factors - The Analytic Hierarchy/Network Process. Review of the Royal 
Academy of Exact, Physical and Natural Sciences, Series A: Mathematics (RACSAM). 102 (2): 251-318.

Saraf, A. K. and Choudhury, P. R. (1998): Integrated remote sensing and GIS for groundwater exploration and identification of artificial recharge sites. International Journal of Remote Sensing, 19 (10), 2595-2616.

Scanlon, BR., Keese, KE., Flint, AL., Flint, LE., Gaye, CB., Edmunds, M., Simmers, I. (2006): Global synthesis of groundwater recharge in semiarid and arid regions. Hydrol Process 20:3335-3370

SCS national engineering handbook (1985): Section 4; hydrology. Soil conservation service USDA Washington D.C.

Shatnawi, G. (2006): Determine the Best Sites for Water Harvesting Projects (Dams \& Hafirs) in Northeastern Badia Using GIS Applications. Unpublished M.Sc. thesis, Al AlBayt University, Jordan.

Smith, A. J. and Pollock, D. W. (2012): Assessment of Managed Aquifer Recharge . Potential Using Ensembles of Local Models . Vol. 50, No. 1-GROUND WATER(pages 133-143).

Steinel, A. (2012): Pre-feasibility study for infiltration of floodwater in the AmmanZarqa and Azraq basins, Jordan. TECHNICAL COOPERATION PROJECT No. 2002.3510.1 GeoSFF Study, Hannover 2012.

Taheri, A. and Zare, M. (2011): Groundwater artificial recharge assessment in Kangavar Basin, a semi-arid region in the western part of Iran, African Journal of Agricultural Research Vol. 6(17), pp. 4370-4384.

van Zyl, W.H., de Jager, J.M. and Maree, C.J. (1989): Correction factors for evaporimeter coefficients used for scheduling irrigation of wheat. Bloemfontein, University of the Orange Free State. Executive Summary for Water Research Commission by Department of Agrometeorology.

Voudouris, K.S. (2006): Groundwater Balance and Safe Yield of the coastal aquifer system in NE astern Korinthia, Greece Applied Geography 26 (2006) 291-311

WAJ (1989): North Jordan water resources project, Investigation Project Staff. Unpubl. Report at the Water Authority of Jordan, Amman, Jordan. 66 pp 
WAJ and BGR (1994): Water Authority of Jordan (WAJ) and the Federal Institute for Geosciences and Natural Resources (BGR), Ground Water Resources of Northern Jordan; Vol 3. Structural features of the main hydrogeological units in Northern Jordan, Project No. 89.2105.8, Amman.

WAJ and BGR (1996): Water Authority of Jordan and the Federal Institute for Geosciences and Natural Resources (BGR), Ground Water Resources of Northern Jordan; Vol 1. Rainfall, Spring Discharge and Baseflow, Part 2. Spring Discharge in Northern Jordan, Project No. 89.2105.8, Amman.

Warburton, J. (1998): A reconnaissance survey of surface water infiltration characteristics. In: Arid Land Resources and their Management. Jordan's Desert Margin. Dutton, R.W., Clarke, J.I. and Battikhi, A.M. (Eds.). London, Kegan Paul International, p. $157-170$.

Yalcin, A. (2008): GIS-based landslide susceptibility mapping using analytical hierarchy process and bivariate statistics in Ardesen (Turkey), comparisons of results and confirmations. Catena 72, 1-12.

Yoo, C. and Kim, J. M. (2007): Tunneling performance prediction using integrated GIS and neural network.Computers \& Geotechnics, 34 (1), 19-30.

Zaidi, F. K., Nazzal, Y., Ahmed, I., Naeem, M., Jafri, M.K. (2015): Identification of potential artificial groundwater recharge zones in Northwestern Saudi Arabia using GIS and Boolean logic. Journal of African Earth Sciences 111, 156-169

Zektser, S., Loáiciga . H. A. and Wolf, J. T. (2005): Environmental impacts of groundwater overdraft: selected case studies in the southwestern United States. Environmental Geology, Volume 47, Issue 3, pp 396-404.

Ziadat, F.M., Taimeh, A.Y. and Hattar, B.I. (2010): "Variation of Soil Physical Properties and Moisture Content Along Toposequences in the Arid to Semiarid Area." Arid Land Research and Management 24(2): 81-97. 


\section{Appendixes}

\section{Appendix A Yearly abstraction rate from private and governmental wells in Azraq basin}

\begin{tabular}{|c|c|c|}
\hline & $\begin{array}{l}\text { Abstraction through private wells } \\
\text { MCM/a }\end{array}$ & Abstraction through AWSA wells MCM/a \\
\hline 1981 & 1.67 & 0.00 \\
\hline 1982 & 1.25 & 10.50 \\
\hline 1983 & 1.25 & 12.31 \\
\hline 1984 & 1.66 & 13.73 \\
\hline 1985 & 2.91 & 15.68 \\
\hline 1986 & 3.74 & 13.78 \\
\hline 1987 & 6.65 & 14.14 \\
\hline 1988 & 9.97 & 18.63 \\
\hline 1989 & 12.83 & 16.92 \\
\hline 1990 & 16.85 & 18.04 \\
\hline 1991 & 20.96 & 18.12 \\
\hline 1992 & 23.95 & 18.92 \\
\hline 1993 & 24.83 & 19.74 \\
\hline 1994 & 21.07 & 19.95 \\
\hline 1995 & 19.54 & 22.77 \\
\hline 1996 & 18.07 & 23.22 \\
\hline 1997 & 20.16 & 21.59 \\
\hline 1998 & 21.40 & 21.17 \\
\hline 1999 & 22.58 & 18.57 \\
\hline 2000 & 22.51 & 18.98 \\
\hline 2001 & 25.30 & 19.88 \\
\hline 2002 & 27.75 & 12.40 \\
\hline 2003 & 27.29 & 14.05 \\
\hline 2004 & 27.21 & 16.41 \\
\hline 2005 & 26.49 & 15.87 \\
\hline 2006 & 27.45 & 16.13 \\
\hline 2007 & 24.63 & 18.70 \\
\hline 2008 & 19.72 & 18.48 \\
\hline 2009 & 17.62 & 18.53 \\
\hline 2010 & 16.04 & 16.24 \\
\hline 2011 & 18.12 & 20.44 \\
\hline 2012 & 17.63 & 20.76 \\
\hline 2013 & 22.44 & 16.36 \\
\hline
\end{tabular}




\section{Appendix B yearly rainfall and groundwater recharge $(\mathrm{mm})$ in the wadis of}

Azraq basin

\begin{tabular}{|c|c|c|c|c|c|c|c|c|}
\hline & \multicolumn{2}{|c|}{ Jesha } & \multicolumn{2}{|c|}{ Aseikhim } & \multicolumn{2}{|c|}{ Rajil } & \multicolumn{2}{|c|}{ U-B-H } \\
\hline Year & $\begin{array}{l}\text { Rain } \\
\text { mm }\end{array}$ & $\begin{array}{l}\text { Recharge } \\
\mathrm{mm}\end{array}$ & Rain $\mathrm{mm}$ & $\begin{array}{l}\text { Recharge } \\
\mathrm{mm}\end{array}$ & $\begin{array}{l}\text { Rain } \\
\mathrm{mm}\end{array}$ & $\begin{array}{l}\text { Recharge } \\
\mathrm{mm}\end{array}$ & $\begin{array}{l}\text { Rain } \\
\text { mm }\end{array}$ & $\begin{array}{l}\text { Recharge } \\
\mathrm{mm}\end{array}$ \\
\hline $70-71$ & 53.4 & 0.0 & 105.2 & 0.5 & 142.6 & 2.9 & 124.0 & 6.1 \\
\hline $71-72$ & 84.1 & 2.9 & 178.6 & 1.0 & 166.4 & 5.0 & 149.1 & 4.6 \\
\hline $72-73$ & 34.9 & 0.2 & 70.5 & 0.4 & 60.0 & 1.4 & 65.2 & 3.1 \\
\hline $73-74$ & 69.8 & 0.0 & 217.9 & 5.6 & 210.1 & 11.8 & 167.3 & 14.0 \\
\hline $74-75$ & 61.2 & 2.7 & 134.8 & 8.4 & 125.5 & 6.2 & 122.3 & 10.3 \\
\hline $75-76$ & 40.9 & 0.2 & 127.9 & 4.9 & 106.8 & 6.3 & 99.6 & 4.6 \\
\hline $76-77$ & 8.3 & 0.0 & 74.4 & 0.2 & 72.7 & 1.4 & 46.4 & 0.0 \\
\hline $77-78$ & 30.7 & 0.0 & 76.2 & 0.4 & 49.9 & 2.6 & 72.4 & 6.6 \\
\hline $78-79$ & 20.3 & 0.0 & 54.8 & 0.1 & 61.8 & 0.8 & 47.5 & 2.9 \\
\hline $79-80$ & 49.5 & 0.0 & 197.8 & 5.6 & 193.0 & 13.2 & 113.4 & 4.1 \\
\hline $80-81$ & 34.1 & 0.5 & 149.7 & 11.2 & 152.5 & 7.6 & 114.2 & 17.3 \\
\hline $81-82$ & 42.0 & 0.0 & 122.2 & 1.1 & 127.7 & 2.2 & 84.1 & 0.0 \\
\hline $82-83$ & 16.2 & 0.0 & 93.2 & 0.3 & 88.7 & 1.7 & 90.8 & 0.6 \\
\hline $83-84$ & 15.3 & 0.0 & 63.9 & 0.2 & 57.7 & 1.2 & 33.2 & 0.6 \\
\hline $84-85$ & 15.0 & 0.0 & 93.8 & 0.0 & 70.4 & 0.0 & 83.7 & 1.5 \\
\hline $85-86$ & 69.2 & 0.1 & 108.9 & 0.4 & 111.7 & 2.3 & 53.5 & 1.1 \\
\hline $86-87$ & 32.3 & 0.0 & 118.8 & 6.0 & 97.9 & 5.8 & 57.0 & 2.3 \\
\hline $87-88$ & 79.0 & 0.0 & 183.7 & 1.3 & 162.4 & 5.3 & 128.6 & 6.3 \\
\hline $88-89$ & 75.7 & 5.7 & 162.3 & 14.3 & 99.5 & 7.0 & 130.3 & 16.9 \\
\hline $89-90$ & 28.5 & 0.0 & 152.4 & 0.7 & 106.8 & 4.4 & 105.1 & 0.9 \\
\hline $90-91$ & 76.4 & 12.7 & 153.8 & 6.0 & 150.4 & 10.9 & 82.6 & 3.2 \\
\hline $91-92$ & 17.7 & 0.0 & 107.9 & 1.1 & 110.0 & 6.7 & 59.7 & 7.5 \\
\hline $92-93$ & 11.9 & 0.0 & 90.4 & 0.4 & 90.5 & 2.4 & 52.6 & 2.0 \\
\hline $93-94$ & 93.0 & 0.0 & 83.0 & 0.0 & 63.8 & 0.7 & 55.4 & 0.3 \\
\hline $94-95$ & 49.5 & 6.5 & 106.8 & 0.7 & 131.7 & 5.2 & 107.1 & 5.1 \\
\hline $95-96$ & 30.7 & 0.0 & 60.3 & 0.4 & 72.7 & 2.4 & 53.6 & 1.2 \\
\hline $96-97$ & 74.8 & 0.0 & 135.2 & 0.2 & 108.1 & 1.4 & 83.3 & 2.2 \\
\hline $97-98$ & 64.2 & 0.0 & 149.2 & 1.0 & 132.5 & 2.1 & 87.6 & 1.0 \\
\hline $98-99$ & 15.2 & 0.0 & 29.3 & 0.0 & 22.4 & 0.0 & 32.6 & 0.0 \\
\hline $99-2000$ & 3.5 & 0.0 & 24.9 & 0.3 & 35.1 & 2.1 & 25.0 & 0.0 \\
\hline $2000-01$ & 67.1 & 1.1 & 81.7 & 0.2 & 97.6 & 1.1 & 75.7 & 0.0 \\
\hline $2001-02$ & 2.1 & 0.0 & 83.2 & 1.7 & 97.5 & 4.1 & 70.0 & 0.5 \\
\hline $2002-03$ & 50.2 & 0.1 & 95.8 & 1.5 & 138.7 & 6.5 & 85.8 & 4.1 \\
\hline $2003-04$ & 54.5 & 2.6 & 104.9 & 1.8 & 91.8 & 0.1 & 89.7 & 4.4 \\
\hline 2004-05 & 57.2 & 0.0 & 18.2 & 0.0 & 59.5 & 0.0 & 70.6 & 7.0 \\
\hline
\end{tabular}




\begin{tabular}{|l|l|l|l|l|l|l|l|l|}
\hline $2005-2006$ & 6.7 & 0.0 & 55.5 & 1.1 & 63.1 & 1.5 & 68.4 & 5.4 \\
\hline $2006-07$ & 56.3 & 0.0 & 88.3 & 1.2 & 70.2 & 2.5 & 70.3 & 7.9 \\
\hline $2007-08$ & 40.3 & 0.0 & 51.9 & 0.1 & 52.0 & 0.7 & 62.8 & 4.5 \\
\hline $2008-09$ & 12.5 & 0.0 & 33.0 & 0.1 & 31.5 & 0.4 & 44.3 & 4.5 \\
\hline $2009-10$ & 41.2 & 0.0 & 92.1 & 0.8 & 86.1 & 2.5 & 90.1 & 4.8 \\
\hline $2010-11$ & 61.6 & 0.0 & 103.4 & 3.5 & 92.1 & 5.0 & 89.5 & 3.3 \\
\hline $2011-12$ & 23.3 & 0.0 & 100.1 & 0.9 & 101.1 & 5.1 & 100.7 & 7.4 \\
\hline $2012-13$ & 25.6 & 0.0 & 81.5 & 1.0 & 76.8 & 3.9 & 57.1 & 2.2 \\
\hline $2013-14$ & 73.0 & 16.3 & 99.3 & 0.9 & 100.7 & 2.2 & 62.6 & 1.9 \\
\hline $\begin{array}{l}\text { Longterm- } \\
\text { average }\end{array}$ & $\mathbf{4 2 . 5}$ & $\mathbf{1 . 2}$ & $\mathbf{1 0 2 . 7}$ & $\mathbf{2 . 0}$ & $\mathbf{9 8 . 6}$ & $\mathbf{3 . 6}$ & $\mathbf{8 1 . 0}$ & $\mathbf{4 . 2}$ \\
\hline
\end{tabular}

\begin{tabular}{|c|c|c|c|c|c|c|}
\hline & \multicolumn{2}{|c|}{ Mudeisisat } & \multicolumn{2}{|c|}{ Hassan } & \multicolumn{2}{|c|}{ Ghadaf } \\
\hline Year & $\begin{array}{l}\text { Rain } \\
\mathrm{mm}\end{array}$ & $\begin{array}{c}\text { Recharge } \\
\text { mm }\end{array}$ & $\begin{array}{l}\text { Rain } \\
\text { mm }\end{array}$ & $\begin{array}{c}\text { Recharge } \\
\text { mm }\end{array}$ & $\begin{array}{l}\text { Rain } \\
\mathrm{mm}\end{array}$ & $\begin{array}{c}\text { Recharge } \\
\text { mm }\end{array}$ \\
\hline $70-71$ & 183.8 & 14.1 & 156.6 & 2.0 & 92.9 & 4.0 \\
\hline $71-72$ & 177.8 & 10.7 & 230.1 & 3.9 & 115.0 & 4.8 \\
\hline $72-73$ & 85.5 & 2.1 & 82.9 & 1.1 & 50.7 & 1.1 \\
\hline $73-74$ & 250.0 & 32.3 & 264.8 & 7.3 & 124.3 & 9.2 \\
\hline $74-75$ & 162.4 & 8.4 & 169.3 & 11.7 & 92.9 & 5.2 \\
\hline $75-76$ & 151.1 & 5.3 & 177.4 & 9.9 & 74.1 & 2.0 \\
\hline $76-77$ & 93.9 & 0.0 & 119.2 & 1.0 & 32.8 & 0.0 \\
\hline $77-78$ & 114.5 & 15.2 & 105.3 & 1.8 & 55.4 & 4.3 \\
\hline $78-79$ & 70.7 & 6.6 & 81.3 & 0.5 & 35.6 & 1.9 \\
\hline $79-80$ & 197.7 & 9.5 & 302.8 & 10.3 & 91.4 & 2.7 \\
\hline $80-81$ & 159.6 & 26.5 & 204.0 & 17.4 & 74.3 & 8.9 \\
\hline $81-82$ & 115.1 & 0.0 & 162.1 & 2.7 & 64.6 & 0.0 \\
\hline $82-83$ & 112.8 & 1.4 & 118.1 & 1.2 & 49.4 & 0.4 \\
\hline $83-84$ & 49.8 & 1.5 & 87.1 & 0.8 & 25.6 & 0.4 \\
\hline $84-85$ & 120.9 & 3.4 & 111.0 & 0.2 & 49.1 & 1.0 \\
\hline $85-86$ & 66.4 & 0.5 & 129.2 & 1.6 & 65.8 & 0.4 \\
\hline $86-87$ & 76.6 & 5.2 & 166.8 & 11.0 & 45.9 & 1.5 \\
\hline $87-88$ & 175.3 & 14.6 & 233.2 & 4.2 & 107.7 & 4.1 \\
\hline $88-89$ & 135.9 & 22.0 & 154.7 & 13.8 & 97.9 & 11.1 \\
\hline $89-90$ & 121.5 & 1.5 & 192.4 & 3.1 & 61.3 & 0.5 \\
\hline $90-91$ & 81.7 & 3.0 & 184.1 & 6.2 & 78.6 & 9.0 \\
\hline $91-92$ & 80.5 & 17.4 & 166.3 & 4.7 & 38.1 & 4.9 \\
\hline $92-93$ & 72.1 & 4.6 & 129.9 & 1.7 & 31.6 & 1.3 \\
\hline $93-94$ & 91.8 & 0.6 & 89.4 & 0.0 & 86.0 & 0.2 \\
\hline 94-95 & 135.6 & 11.8 & 117.6 & 2.6 & 77.5 & 7.3 \\
\hline $95-96$ & 107.3 & 2.8 & 84.2 & 1.7 & 50.5 & 0.8 \\
\hline
\end{tabular}




\begin{tabular}{|l|l|l|l|l|l|l|}
\hline $96-97$ & 122.3 & 5.1 & 146.2 & 1.0 & 86.1 & 1.5 \\
\hline $97-98$ & 89.4 & 2.3 & 197.9 & 3.1 & 73.6 & 0.7 \\
\hline $98-99$ & 45.8 & 0.0 & 24.9 & 0.0 & 24.6 & 0.0 \\
\hline $99-2000$ & 45.9 & 0.0 & 45.0 & 1.5 & 16.1 & 0.0 \\
\hline $2000-01$ & 114.7 & 0.0 & 95.6 & 0.7 & 78.4 & 0.6 \\
\hline $2001-02$ & 110.6 & 1.1 & 124.3 & 4.7 & 36.5 & 0.3 \\
\hline $2002-03$ & 141.2 & 6.4 & 150.2 & 5.4 & 75.3 & 2.1 \\
\hline $2003-04$ & 102.1 & 1.9 & 109.8 & 1.8 & 70.6 & 2.8 \\
\hline $2004-05$ & 163.0 & 16.2 & 0.0 & 0.0 & 81.4 & 4.6 \\
\hline $2005-2006$ & 137.2 & 12.5 & 84.9 & 2.6 & 44.6 & 3.6 \\
\hline $2006-07$ & 128.6 & 18.2 & 129.3 & 3.2 & 73.7 & 5.1 \\
\hline $2007-08$ & 97.7 & 10.5 & 59.0 & 0.7 & 56.1 & 3.0 \\
\hline $2008-09$ & 85.5 & 10.3 & 41.4 & 0.3 & 33.2 & 2.9 \\
\hline $2009-10$ & 136.7 & 11.0 & 111.0 & 2.4 & 69.6 & 3.1 \\
\hline $2010-11$ & 128.2 & 7.5 & 129.3 & 8.3 & 80.3 & 2.1 \\
\hline $2011-12$ & 195.9 & 17.0 & 161.0 & 3.8 & 72.7 & 4.8 \\
\hline $2012-13$ & 106.0 & 5.0 & 130.3 & 3.6 & 47.8 & 1.4 \\
\hline $2013-14$ & 94.9 & 4.5 & 132.8 & 2.8 & 75.7 & 1.3 \\
\hline $\begin{array}{l}\text { Long term- } \\
\text { average }\end{array}$ & $\mathbf{1 1 9 . 0}$ & $\mathbf{8 . 0}$ & 133.9 & $\mathbf{3 . 8}$ & 65.1 & $\mathbf{2 . 9}$ \\
\hline
\end{tabular}

\begin{tabular}{|l|l|l|l|l|l|l|}
\hline & \multicolumn{2}{|c|}{ Khanna } & \multicolumn{2}{c|}{ Rattam } & \multicolumn{2}{c|}{ Uniqya } \\
\hline Year & $\begin{array}{c}\text { Rain } \\
\mathbf{m m}\end{array}$ & $\begin{array}{c}\text { Recharge } \\
\mathbf{m m}\end{array}$ & $\begin{array}{c}\text { Rain } \\
\mathbf{m m}\end{array}$ & $\begin{array}{c}\text { Recharge } \\
\mathbf{m m}\end{array}$ & $\begin{array}{c}\text { Rain } \\
\mathbf{m m}\end{array}$ & $\begin{array}{c}\text { Recharge } \\
\mathbf{m m}\end{array}$ \\
\hline $70-71$ & 187.5 & 0.5 & 66.6 & 0.0 & 61.9 & 0.0 \\
\hline $71-72$ & 185.1 & 0.6 & 122.8 & 0.0 & 121.1 & 0.0 \\
\hline $72-73$ & 71.9 & 0.2 & 49.0 & 0.3 & 48.7 & 0.3 \\
\hline $73-74$ & 226.7 & 12.6 & 113.7 & 0.3 & 117.6 & 0.4 \\
\hline $74-75$ & 153.9 & 11.9 & 91.9 & 8.2 & 92.1 & 8.0 \\
\hline $75-76$ & 135.1 & 7.2 & 65.3 & 0.7 & 67.3 & 1.0 \\
\hline $76-77$ & 92.2 & 0.1 & 21.2 & 0.0 & 25.6 & 0.0 \\
\hline $77-78$ & 81.8 & 0.3 & 45.2 & 0.0 & 47.1 & 0.0 \\
\hline $78-79$ & 70.1 & 0.1 & 31.6 & 0.0 & 32.3 & 0.0 \\
\hline $79-80$ & 219.4 & 2.3 & 70.0 & 0.0 & 78.4 & 0.0 \\
\hline $80-81$ & 145.0 & 8.0 & 83.5 & 7.1 & 85.2 & 7.2 \\
\hline $81-82$ & 96.8 & 0.7 & 65.9 & 0.0 & 68.2 & 0.0 \\
\hline $82-83$ & 99.8 & 0.2 & 70.0 & 0.0 & 68.3 & 0.0 \\
\hline $83-84$ & 81.8 & 0.4 & 27.4 & 0.0 & 30.1 & 0.0 \\
\hline $84-85$ & 131.8 & 2.0 & 60.5 & 0.0 & 62.6 & 0.0 \\
\hline $85-86$ & 104.4 & 0.3 & 49.0 & 0.0 & 51.2 & 0.0 \\
\hline $86-87$ & 116.3 & 10.8 & 51.6 & 1.6 & 55.4 & 2.3 \\
\hline
\end{tabular}




\begin{tabular}{|c|c|c|c|c|c|c|}
\hline $87-88$ & 170.8 & 0.8 & 103.6 & 0.0 & 107.8 & 0.0 \\
\hline $88-89$ & 103.6 & 4.6 & 124.4 & 10.9 & 123.8 & 11.4 \\
\hline $89-90$ & 148.4 & 0.4 & 96.3 & 0.0 & 97.8 & 0.0 \\
\hline $90-91$ & 134.5 & 1.1 & 87.8 & 0.8 & 89.6 & 1.1 \\
\hline $91-92$ & 134.3 & 0.7 & 49.1 & 0.0 & 51.1 & 0.0 \\
\hline $92-93$ & 105.2 & 0.2 & 42.2 & 0.0 & 43.9 & 0.0 \\
\hline $93-94$ & 70.0 & 0.0 & 41.8 & 0.0 & 47.6 & 0.0 \\
\hline $94-95$ & 90.2 & 0.4 & 77.7 & 0.0 & 74.6 & 0.0 \\
\hline $95-96$ & 60.6 & 0.2 & 19.0 & 0.0 & 21.6 & 0.0 \\
\hline $96-97$ & 96.5 & 0.1 & 70.2 & 0.0 & 76.9 & 0.0 \\
\hline $97-98$ & 168.9 & 5.5 & 89.3 & 0.0 & 90.6 & 0.0 \\
\hline $98-99$ & 17.1 & 0.0 & 21.3 & 0.0 & 20.8 & 0.0 \\
\hline $99-2000$ & 47.3 & 0.2 & 8.0 & 0.0 & 7.6 & 0.0 \\
\hline $2000-01$ & 88.1 & 0.1 & 45.8 & 0.0 & 45.7 & 0.0 \\
\hline 2001-02 & 106.5 & 1.1 & 38.0 & 0.0 & 37.7 & 0.0 \\
\hline 2002-03 & 131.2 & 1.0 & 40.9 & 0.0 & 39.9 & 0.0 \\
\hline $2003-04$ & 74.1 & 0.6 & 79.1 & 1.6 & 78.7 & 1.7 \\
\hline 2004-05 & 0.0 & 0.0 & 0.0 & 0.0 & 0.0 & 0.0 \\
\hline $2005-2006$ & 70.7 & 0.7 & 19.8 & 0.0 & 21.4 & 0.0 \\
\hline 2006-07 & 86.2 & 0.8 & 35.5 & 0.0 & 39.4 & 0.0 \\
\hline 2007-08 & 71.2 & 2.5 & 34.4 & 0.0 & 33.7 & 0.0 \\
\hline 2008-09 & 42.8 & 0.0 & 15.6 & 0.0 & 16.7 & 0.0 \\
\hline $2009-10$ & 83.4 & 0.5 & 56.2 & 0.0 & 57.0 & 0.0 \\
\hline $2010-11$ & 81.6 & 2.2 & 62.1 & 0.0 & 62.9 & 0.0 \\
\hline 2011-12 & 109.0 & 0.6 & 36.5 & 0.0 & 39.9 & 0.0 \\
\hline 2012-13 & 126.5 & 3.1 & 29.9 & 0.0 & 34.0 & 0.0 \\
\hline 2013-14 & 100.0 & 6.0 & 44.6 & 0.0 & 47.2 & 0.0 \\
\hline $\begin{array}{l}\text { Longterm- } \\
\text { average }\end{array}$ & 107.2 & 2.1 & 55.8 & 0.7 & 57.3 & 0.8 \\
\hline
\end{tabular}




\section{Appendix C Base map of Shallow and Middle aquifer systems and B3 aquitard in Azraq basin}

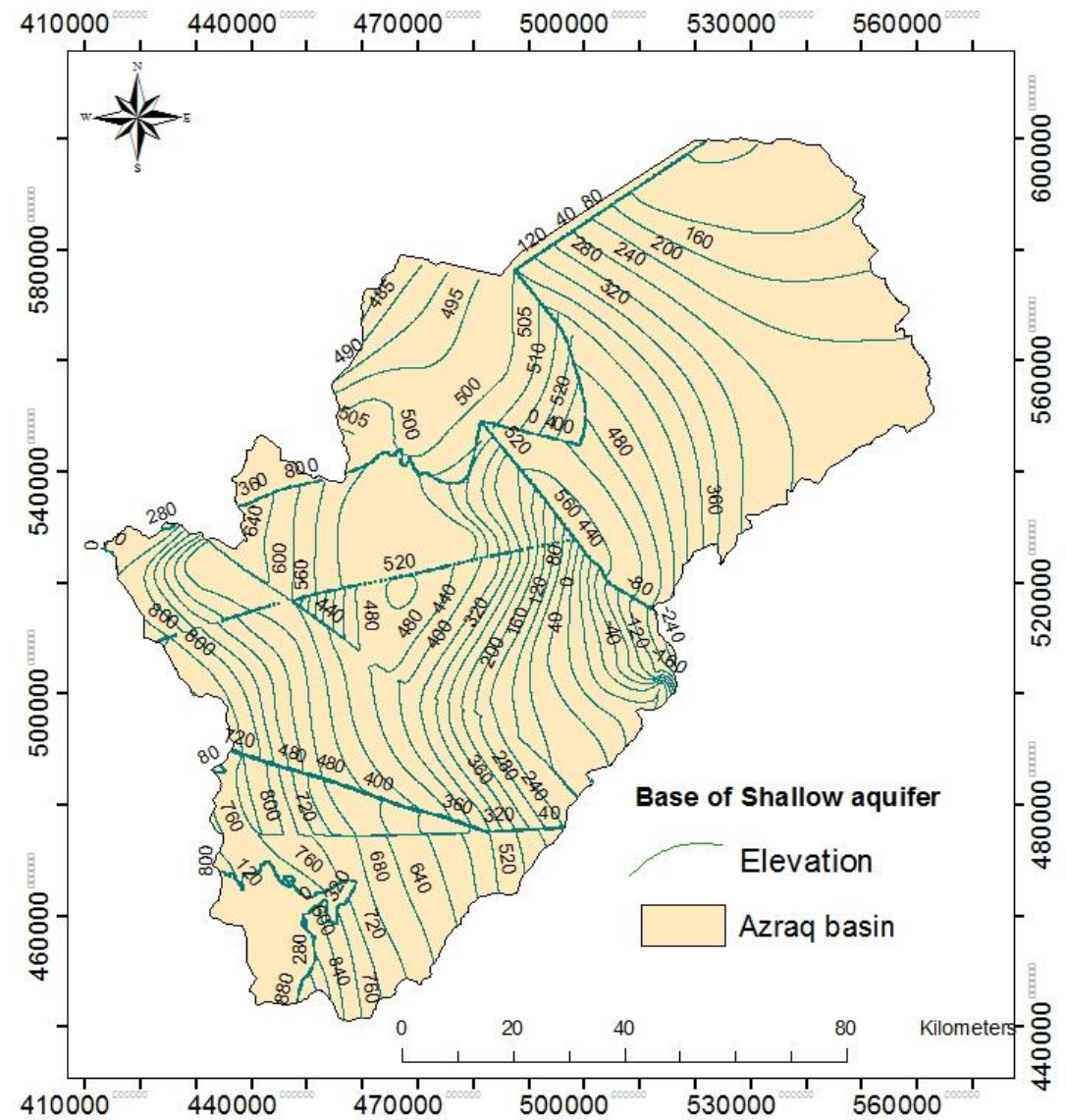



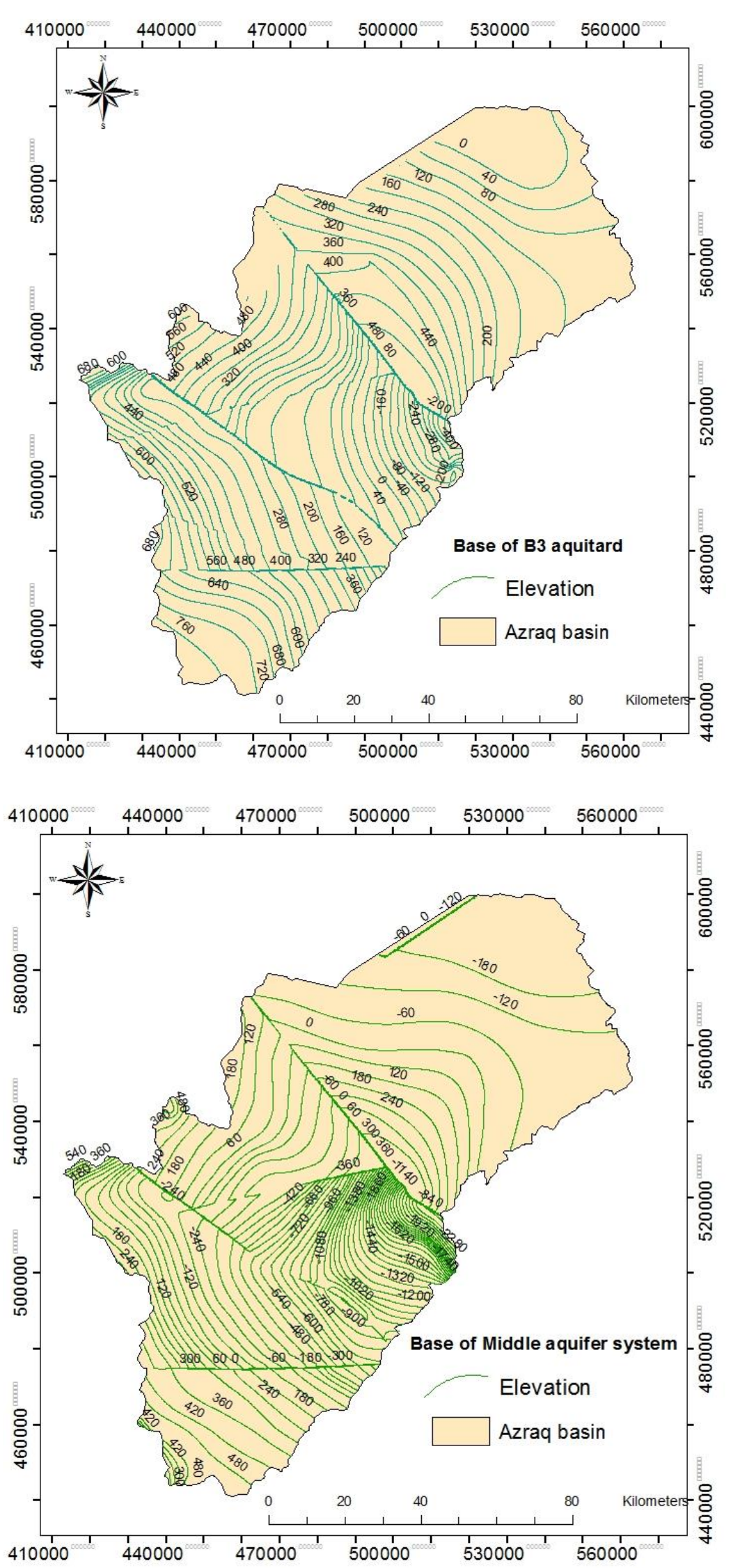


\section{Appendix D Simulation results under pumping scenarios}
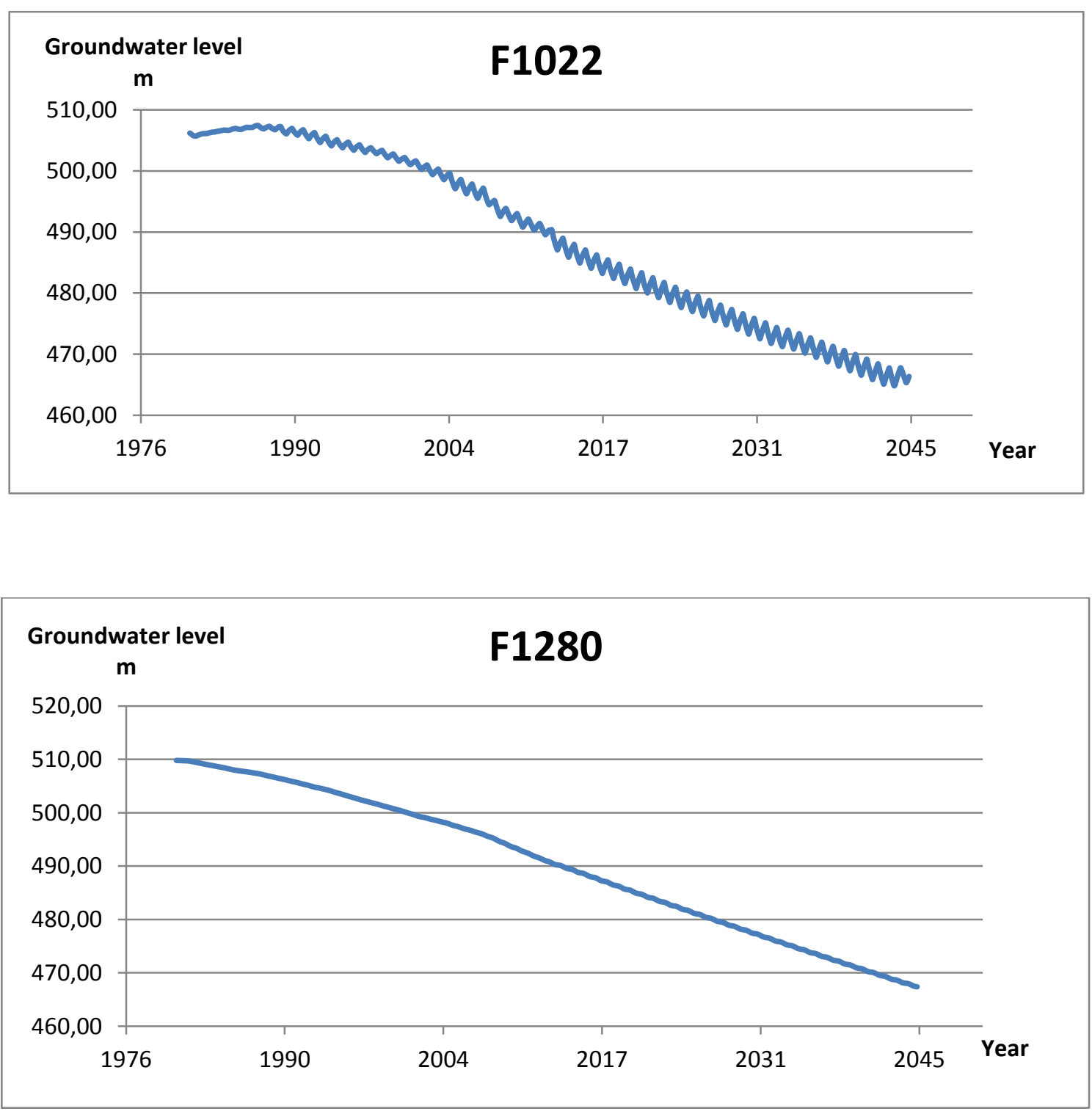

Simulation results under pumping scenario one 

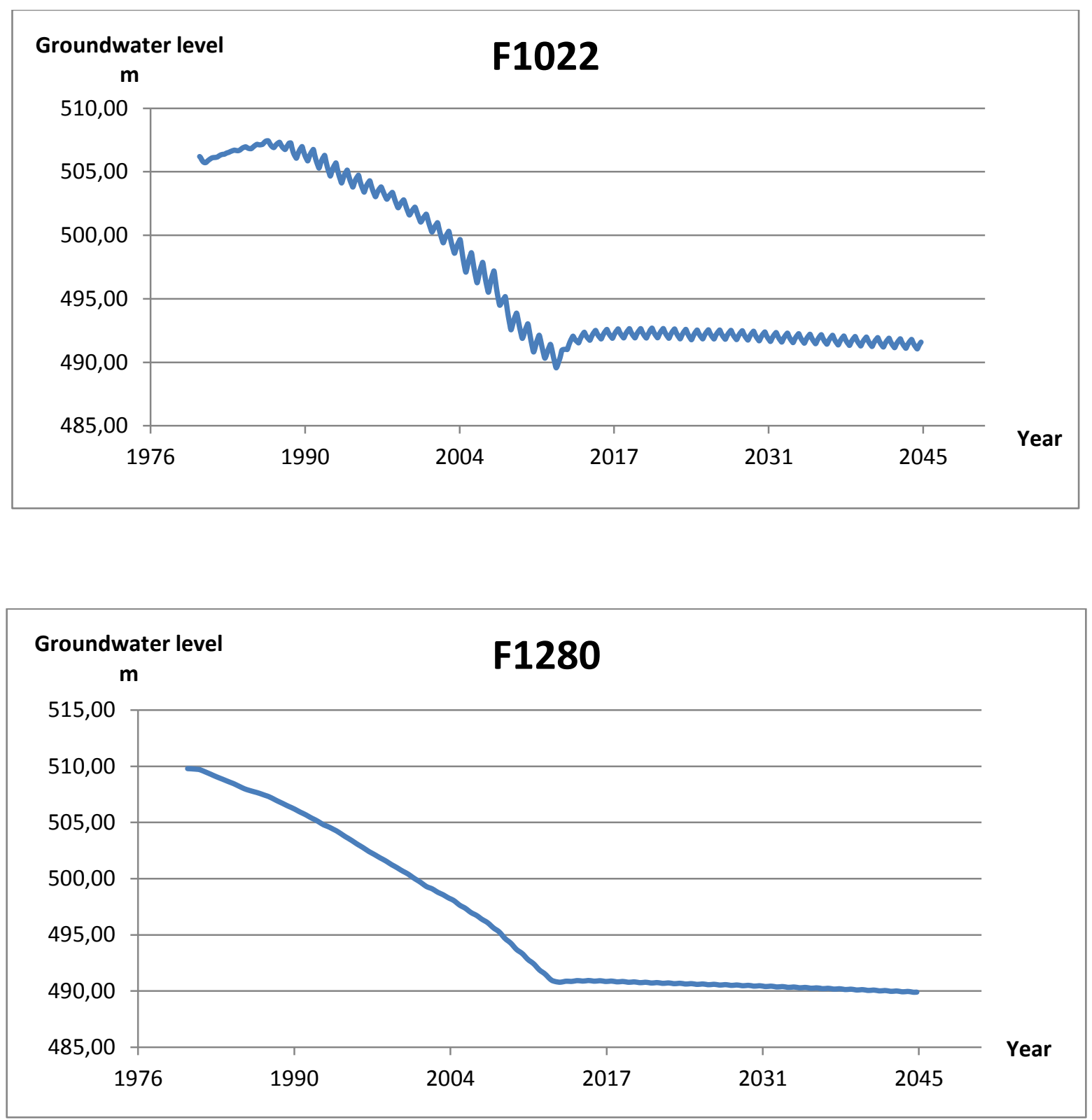

Simulation results under Safe Yield pumping scenario 